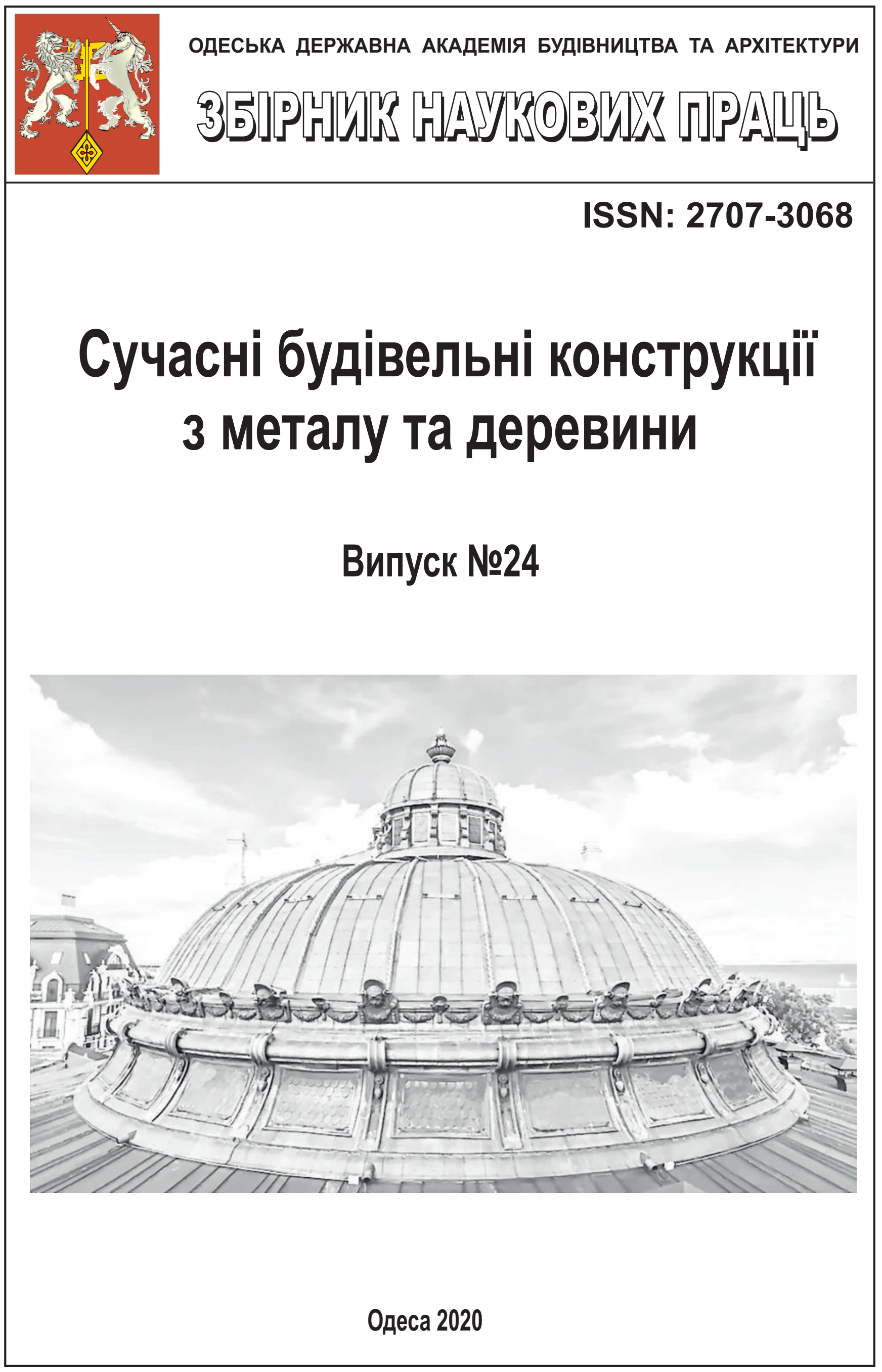


ISSN: 2707-3068

\section{МIHICТЕРСТВО ОСВІТИ І НАУКИ УКРАЇНИ}

ОДЕСЬКА ДЕРЖАВНА АКАДЕМІЯ БУДІВНИЦТВА ТА АРХІТЕКТУРИ

ЗБІРНИК НАУКОВИХ ПРАЦЬ

\section{СУЧАСНІ БУДІВЕЛЬНІ КОНСТРУКЦІЇ \\ 3 МЕТАЛУ ТА ДЕРЕВИНИ}

Випуск № 24

ОДЕСА 2020 


\section{СУЧАСНІ БУДІВЕЛЬНІ КОНСТРУКЦІї 3 МЕТАЛУ ТА ДЕРЕВИНИ}

ISSN: 2707-3068

Випуск № 24, 2020p.

Збірник наукових праць видається з 1992 р., періодичність - 1 раз на рік.

Засновник і видавець - Одеська державна академія будівництва та архітектури.

Свідоцтво про державну реєстрацію КВ 16172-4644Р від 02.12.2009

Збірник наукових праць входить до переліку наукових фахових видань України, у яких можуть публікуватися результати дисертаційних робіт. Наказ МОН України № 409 від 17.03.2020 року (категорія Б).

\section{WorldCat.}

Збірник наукових праць включено до міжнародної науковометричної бази

У збірнику представлені результати наукових і експериментально-теоретичних досліджень будівельних конструкцій з металу та деревини. Призначений для наукових працівників, спеціалістів проектних установ та виробничих підприємств будівельної галузі, аспірантів та магістрів навчальних закладів.

Головний редактор - Карпюк В.М. - д-р техн. наук, проф., ОДАБА;

Відповідальний редактор - Клименко Є.В. - д-р техн. наук, проф., ОДАБА;

Відповідальний секретар - Гілодо О.Ю. - к-т техн. наук, доц., ОДАБА.

Редакційна колегія:

Білик С.І. - д-р техн. наук, проф., Київський національний університет будівництва i архітектури;

Вировой В.М. - д-р техн. наук, проф., ОДАБА;

Гібаленко О.М. - д-р техн. наук, проф., ДВНЗ «Приазовський державний технічний університет»;

Голоднов О.І. - д-р техн. наук, проф., ТОВ «Укрінсталькон ім. В.М. Шимановського»;

Махінько А.В. - д-р техн. наук, с.н.с., ТОВ «Етуаль»;

Найчук А.Я. - д-р техн. наук, проф., УО «Брестский государственный технический университет», Білорусь;

Пічугін С.Ф. - д-р техн. наук, проф., Полтавський національний технічний університет імені Юрія Кондратюка;

Суханов В.Г. - д-р техн. наук, проф., ОДАБА;

Яковенко І.А. - д-р техн. наук, проф., Національний університет біоресурсів i природокористування України;

Aniskin Aleksej - Ph.D., Assistant Professor University North, Хорватія.

Технічна редакція:

Арсірій А.М. - к-т техн. наук, доц., ОДАБА.

Бояджі А.О. - к-т техн. наук, ст. викл., ОДАБА.

Рекомендовано до видання Вченою радою ОДАБА

Протокол № 12 від 25 червня 2020 р.

Свідоцтво КВ 16172-4644Р від 02.12.2009 p.

Наказ МОН України № 409 від 17.03.2020 р. (категорія Б).

(C) Одеська державна академія

будівництва та архітектури

(ОДАБА), 2020 
ISSN: 2707-3068

MINISTRY OF EDUCATION AND SCIENCE OF UKRAINE ODESSA STATE ACADEMY

OF CIVIL ENGINEERING AND ARCHITECTURE

COLLECTION OF SCIENTIFIC WORKS

MODERN STRUCTURES OF METAL AND WOOD

Issue № 24

ODESSA 2020 


\section{MODERN STRUCTURES OF METAL AND WOOD}

ISSN: 2707-3068

Issue № 24, 2020p.

Collection of scientific works has been published since 1992, frequency - 1 per year.

Founder and publisher - Odessa State Academy of Civil Engineering and Architecture (OSACEA).

Certificate of state registration KB № 16772-4644P, 02 December, 2009.

Collection of scientific works enters the list of scientific editions of Ukraine, in which thesis results can be published. Order of the Ministry of Education and Science of Ukraine № 409, 17 May, 2020 (category B).

Collection of scientific works is included into International scientometric base of the WorldCat.

Results of scientific and experimental-theoretical researches of building structures of metal and wood. It is assigned for scientific workers, specialists of design organizations and manufacturing enterprises of construction domain, postgraduates, masters of educational institutions.

Editor-in-chief - Karpiuk V.M. - D.Sc., Professor, OSACEA;

Executive editor - Klymen ko Y.V. - .Sc., Professor, OSACEA;

Executive Secretary - Gilodo A.Y. - Ph.D., Associate Professor, OSACEA.

Editorial Board:

Bilyk S.I.- D.Sc., Professor, Kyiv National University of Construction and Architecture;

Vyrovoy V.N. - D.Sc., Professor, Odessa State Academy of Civil Engineering and Architecture;

Gibalenko O.M. - D.Sc., Professor, State Higher Education Institution "Pryazovskyi State Technical University";

Holodnov O.I. - D.Sc., Professor, LLC "V. Shimanovsky Ukrainian Institute of Steel Construction";

Makhinko A.V. - D.Sc., Professor, LLC «ETUAL»;

Naichuk A.Y. - D.Sc., Professor, Brest State Technical University, Belarus;

Pichugin S.F. - D.Sc., Professor, National University «Yuri Kondratyuk Poltava Polytechnic»;

Sukhanov V.G. - D.Sc., Professor, Odessa State Academy of Civil Engineering and Architecture;

Yakovenko I.A. - D.Sc., Professor, National university of life and environmental sciences of Ukraine;

Aniskin Aleksej - Ph.D., Assistant Professor University North, Croatia.

Technical editorship:

Arsirii A.M. - Ph.D., Associate Professor, OSACEA;

Boyadzhi A.O. - Ph.D., Senior lecturer, OSACEA.

Recommended for publication by the Academic Board of the OSACEA

Protocol № 12, 05 June, 2020.

Certificate KB № 16172-4644P, 02 December, 2009.

Order of Ministry of Education and Science of Ukraine № № 409, 17 May, 2020 (category B).

(C) Odessa State Academy

of Civil Engineering and Architecture

(OSACEA ), 2020 


\title{
STRAIN-STRESS DISTRIBUTION OF BRACED NODE OF FRAMED MULTI-STOREY WOODEN HOUSE
}

\author{
Gilodo A.Y., Ph.D., Assistant Professor, \\ ORCID: 0000-0001-5387-5538 \\ Arsiriy A.N., Ph.D., Assistant Professor, \\ ORCID: 0000-0003-3262-1488 \\ Odessa State Academy of Civil Engineering and Architecture
}

\begin{abstract}
Framed multi-storey wooden residential construction is developing very rapidly in many countries around the world. The use of wooden infill beams made of wooden glued beams and OSB (oriental strand board) increases the efficiency of design solutions. Especial difficult in the design and manufacture of beam structures in multi-storey framed houses are the beam-column joints, which can be hinged or supple. Preferably, these nodes are considered supple, which ensures the spatial operation of the frame and reduces its deformability against the hinges. As a rule, nodes are executed with steel elements which connect beams to columns by means of bolts and nails. The following constructive decision of a frame node is offered: a rectangular glued column and a crossbar in the form of an I-beam with an OSB-wall and regiments from a bar strengthened by glued wood in supporting zones. Support zones of crossbars are made of continuous rectangular section of a glued bar. For support of crossbars on a column the head with projecting beams from sheet steel up to $4 \mathrm{~mm}$ thick, with apertures for fastening is put on. The overhanging length corresponds to the width of the support zones of the crossbars. After fixing the crossbars to the projecting beam, the support area of he column of the upper floor is connected to the upper shelf of the crossbars with a fastening element in the form of a corner. The wall of the projecting beam is attached to the column, the projecting beam shelf is attached to the bottom shelf of the beam. The vertical walls of the projecting beam on both sides are attached to the wall of the support zone of the beam. To analyze the stress-strain distribution of the I-beam in the software complex "LIRASAPR" was developed a spatial computer model of the node. The stress-strain distribution of the beam was analyzed by the fields of displacements and stresses, as well as by the deformations of the structure. The research results allow us to conclude about the structural reliability of the proposed node solution.
\end{abstract}

Keywords: constituent wooden beam, wood booms, OSB (oriental strand board), finite elements method, structural model.

Introduction. In the last decade, the construction of multi-storey wooden houses has taken on the markets of many countries. In connection with the need to solve environmental problems, research is being conducted and new technologies for the manufacture of wooden structures are being promoted. Thus, in Finland the share of wooden houses is $40 \%$, in Germany - up to $20 \%$ of the construction market, in Austria - about 30\%, in the US and Canada more than $80 \%$, in Japan is $43 \%$ of all residential buildings under construction [1]. In Ukraine, with the exception of the western regions, wood is practically not used even in low-rise construction. And the reasons are not only in the absence of technology, but above all in the traditional habit of reinforced concrete and steel. Indeed, solid wood has significant limitations on load-bearing capacity, even with small runs. But for many years, the industrial production of glued wood has almost equalized its chances with traditional building materials, opened up opportunities to cover large runs. The second, rather psychological than technical problem is the persistent myth of the significant flammability of wood.

In fact, even untreated wooden beams burn for at least 45 minutes, while the steel beam begins to lose its load-bearing capacity at a temperature of $90{ }^{0} \mathrm{C}$ after 4 minutes, and in the reinforced concrete cracks begin to spread, threatening fragile destruction. At the temperature of $500{ }^{0} \mathrm{C}$ steel in 15 minutes completely loses its load-bearing capacity, at the same time low- 
conductivity wood retains the integrity of the structure for a long period and burns slowly. The charred layer smolders and insulates the core, making it difficult for oxygen input, slowing down combustion.

High-rise wooden buildings have been known for more than thousand years. High pagodas in Japan reached 19 floors and to this day still stand in high seismic and humid climates. The main impulse for the development of multi-storey wooden buildings was the development and marketing of various high-strength wood-based structures, such as CLT-panel, glued beams, series SCL structural composite wood. Technical developments and the growing availability of these materials have allowed them to be used as load-bearing elements of the frame: columns, beams, wall panels, floors, as well as partitions and balconies. Based on this, the question arises about their possible correlations. There are three structural systems, which are currently used in the construction of multi-storey wooden buildings: framed (beam-raiser), wall (panel), combined. The main structural materials of the wall (frameless) system are CLT-panels. All bearing elements of the building are made of them. The floors are placed directly on top of the wall panels, thus forming a platform for the construction of the next floor. Exterior and interior walls receive the load from the interflooring. To transfer the load, ensure stability and rigidity, the load-bearing elements are connected to each other lengthwise by metal brackets, which are attached to the CLT-panel with a large number of nails or bolts.

Framed buildings are a frame system, or space framework. In practice, the design of frames in reinforced concrete and steel design structural systems are divided into framed, framed-braced and braced. However, for wooden structures, considering suppleness of the joints, the frame system cannot be used. Therefore, all beam frames are considered as braced systems. It should be borne in mind that the joints of the crossbars with the columns can be both absolutely hinged and supple. There can be no absolutely rigid node. Framed houses can be beamless, with support of CLT-panels on columns, with a longitudinal arrangement of crossbars and leaning against them of plates and with a cross arrangement of beams. Plate structures - beams are designed to receive loads acting only in their area. They are used mainly as independent load-bearing structures of coatings or floors. Further development of flat solid and through structures in modern construction are spatial plates, consisting of regular-plate formations, which have the common name of the structure. Cross - beam structure is a beam cage consisting of cross beams. The positive qualities of structures made of glued wooden elements include: aesthetic expressiveness; spatial rigidity, which contributes to the increase of the spans of the coating and the rejection of the braces of rigidity; the possibility of increasing the ratio of the height of the beams to the width without the risk of losing the stability of the elements; the viscosity of the system, which increases the degree of reliability of the structure in case of local destruction; regularity and uniformity of structural elements, simplicity of a constructive form of beam elements and as a consequence possibility of their manufacturing on the automated lines; high degree of factory readiness of a covering.

Analysis of existing research. Dmitriev P.O., Savitsky M.V., Purhov V.V., Inzhutov I.S., Labudin B.V., Karelsky O.V., Belinska T.I. were engaged in research of problems of construction and work of wooden houses. In work [2] the world experience of multi-storey wooden houses is analyzed, recommendations on the decision of fundamental questions of designing are given. In work [3] modern tendencies of wooden house-building are considered, the review of the implemented significant projects is given. In [4] the issues of fire safety of wooden structures in comparison with reinforced concrete are considered. In [5] the combined constructive systems wood - steel where steel elements provide spatial rigidity of the building and perceive seismic influences are proved. In [6] modern node fastenings of I-beams for low-rise frame construction are described (fig. 1). All fasteners are hinged and can take little effort.

Research objective. Especial difficult in the design and manufacture of beam structures in multi-storey framed houses are the beam-column joints, which can be hinged or supple. Preferably, these nodes are considered supple, which ensures the spatial operation of the frame and reduces its deformability against the hinges. The design of the node is determined mainly by the size, number of connecting elements and the strain in them. As a rule, nodes are executed with steel elements 
which connect beams to columns by means of bolts and nails. Such units have limited bearing capacity and high requirements for tolerances during installation.
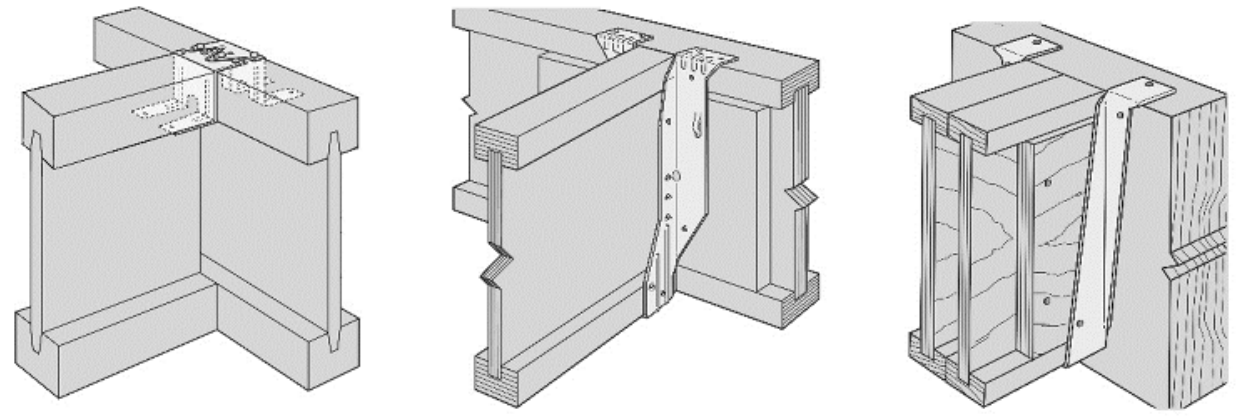

Fig. 1. Supporting nodes of I-beams

All efforts at development of constructive decisions of nodes are directed on reception of equally strong connections with the greatest possible rigidity. This article considers the design and study of the stress-strain distribution of the column assembly with the beam of a frame multi-storey wooden house using a unified steel head with brackets for supporting glued I-beams with a wall of OSB and reinforced support parts.

Constructive solution of the node and stress distribution in its elements. The most vulnerable place in the frames of buildings are the joints of columns with crossbars, which are performed during installation. The following constructive decision of a frame node is offered: a rectangular glued column and a crossbar in the form of an I-beam with an OSB-wall and regiments from a bar strengthened by glued wood in supporting zones.

In the absence of an effective structural solution of the node, in the area of fastening the crossbar to the column with bolts or nails can be observed areas of wrinkling of the wood and the concentration of stresses in the shelves of the crossbars. It is offered for support zones of crossbars to execute continuous rectangular section of a glued bar. For support of crossbars on a column the head with consoles from sheet steel up to $4 \mathrm{~mm}$ thick, with apertures for fastening is put on. The overhanging length corresponds to the width of the support zones of the crossbars.

a)

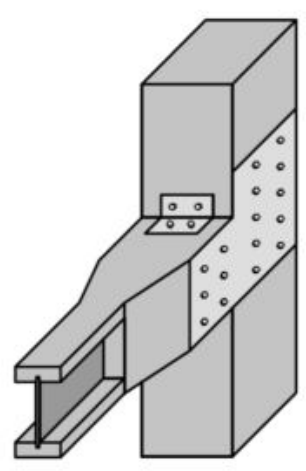

b)

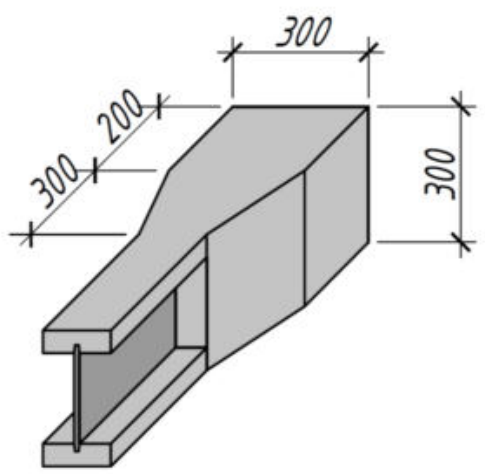

c)

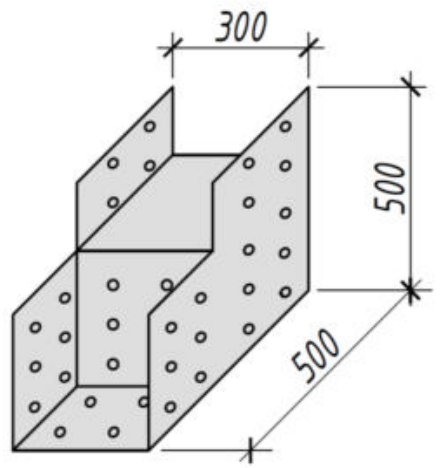

Fig. 2. Constructive solution of the frame node a) general view of the node; b) the supporting part of the I-beam; c) steel head

After fixing the crossbars to the projecting beam, the support area of the column of the upper floor is connected to the upper shelf of the crossbars with a fastening element in the form of a corner (Fig. 2). The upper stretched fastener in the form of a corner is attached to the column of the upper floor and the upper shelf of the beam. The wall of the projecting beam is attached to the column, the projecting beam shelf is attached to the bottom shelf of the beam. The vertical walls of the projecting beam on both sides are attached to the wall of the support zone of the beam. All fasteners are screws. Plastic deformations in the node occur in the initial stages of loading, so the 
recommendations for the calculation at the stage of elastic work for such cases are not relevant. It is necessary to study the work of the projecting beam and the fastener in the form of a corner in interaction with the reinforced wall and the shelves of the crossbar.

Description of the structural model. To analyze the stress-strain distribution of the I-beam in the software complex "LIRA-SAPR" was developed a spatial computer model of the node: a beam of wooden beams - belts and walls of OSB, connected by glue, a column - glued wood. Connective head made of steel sheet, which is attached to the elements with self-tapping screws. The stiffness characteristics of bulk finite elements were set taking into account the anisotropic properties of wood and OSB in accordance with the requirements of [7] and [8].
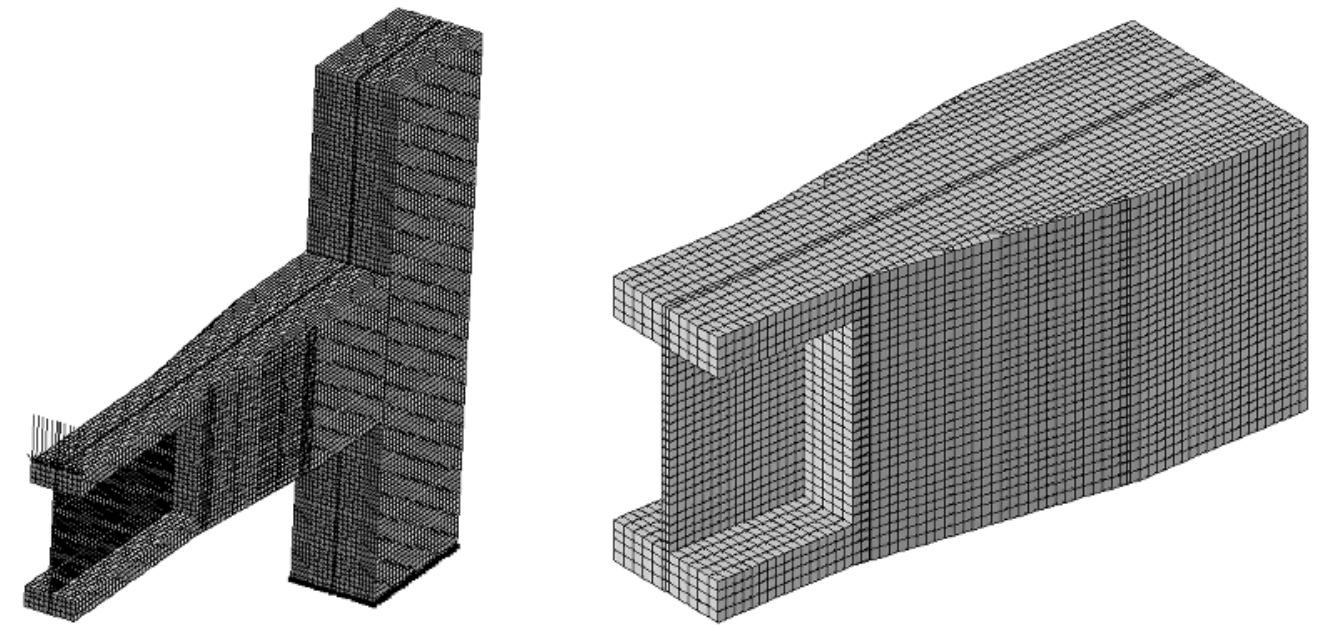

Fig. 3. Fragments of the structural model of the node connection

Belts and beam walls are modeled by universal spatial eight-node isoparametric finite elements (FE №36), metal plates - by universal quadrangular lamellar finite elements shells (FE №44), self-tapping screws - rod elements.

Geometric characteristics: belts of a beam with a section of $150 \times 50 \mathrm{~mm}$ are made of wood of 1 grade, the wall is made of an OSB-3 plate $12 \mathrm{~mm}$ thick. Beam span $6 \mathrm{~m}$, total height of I-beam section - $300 \mathrm{~mm}$. Column - made of glued wood with a cross section of 300x300 mm. Thickness of steel plates - $3 \mathrm{~mm}$, diameter of self-tapping screws - $6 \mathrm{~mm}$. The I-beam is loaded with an evenly distributed load of 1.5-3 kN / m.p.

Research results. The stress-strain distribution of the beam was analyzed by the fields of displacements and stresses, as well as by the deformations of the structure.

In joints of this type, the vulnerable zone is the adhesive joint of the belts and the wall of the beam. The analysis of stresses in this zone shows that increasing the cross section in the support zone with glued wood significantly reduces the stress and increases the bearing capacity of the node by $1.5-2$ times.

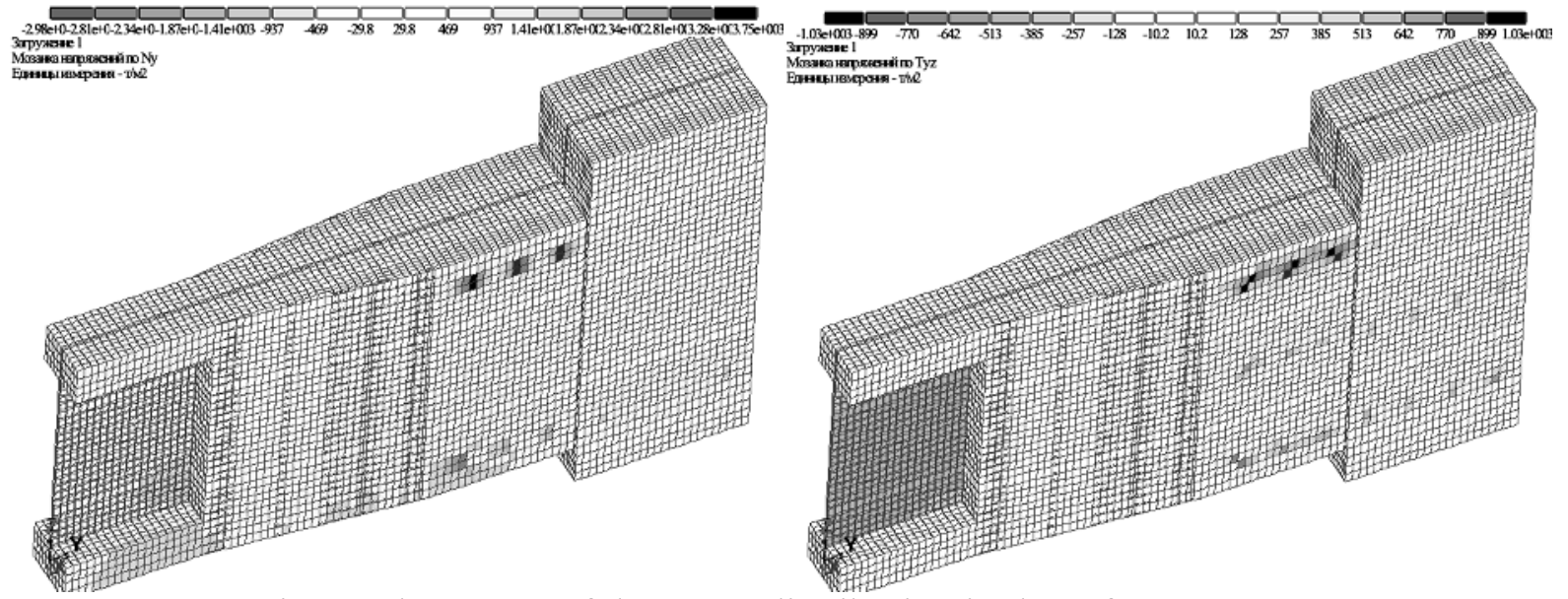

Fig. 4. The nature of the stress distribution in the reference zone
a) normal;
b) tangential 
In addition, at the I-beam section, the wall practically does not perceive the bending moment in the node. When strengthening the support zone, the wall is included in the work on the areas adjacent to the belts (Fig. 4). The design of the unit ensures the reliability of the connection due to the rigidity of the box head and the corner fastener, which includes the column of the upper floor. The proposed design solution reduces the normal stresses in the shelves and in the adhesive joint of the shelves with the wall, reduces the stress at the junction of the corner fastener with the column.

Summary. The results of calculations of the SC "LIRA-SAPR" indicate that the proposed design solution of the node connection can be used as a node of the frames of multi-storey buildings. Increasing the cross section in the support area with glued wood significantly reduces the stress and increases the bearing capacity of the node by 1.5-2 times. The research results allow us to conclude about the structural reliability of the proposed node solution.

\title{
References
}

[1] Bardin I. N. Osobennosti stroitel'stva vysotnykh derevyannykh zdaniy. / I. N. Bardin, A. V. Karel'skiy. // Innovatsii v derevyannom stroitel'stve: materialy 9-y Mezhdunarodnoy nauchnoprakticheskoy konferentsii; SPbGASU. - 2018. -S.18-25.

[2] Savitskiy N.V. Mnogoetazhnoye derevyannoye domostroyeniye: sovremennyye tendentsii i budushchiye perspektivy. / N.V. Savitskiy, S.V. Shekhorkina // Stroitel'stvo, materialovedeniye, mashinostroyeniye // Sb. nauchn. trudov. Vyp. 99.- D.: GVUZ PGSA, 2017. - S.153-159.

[3] Cheban A. Stroitel'stvo derevyannykh neboskrobov [Yelektronniy resurs] / Anika Cheban. 2016. - Rezhim dostupu do resursu: http://zvt.abok.ru/articles/322/Stroitelstvo_derevyannih_neboskryobov.

[4] Mass Timber High-Rise Design Research: Museum Tower in Los Angeles Reimagined in Mass Timber [Yelektronniy resurs]/ [M. Timmers, B. Rogowski, B. Jones ta ín.] // SEAOC CONVENTION PROCEEDINGS. - 2015. - Rezhim dostupu resursu: http://www.woodworks.org/wpcontent/uploads/Mass-Timber-Highrise-Design-Research.pdf.

[5] Green M. THE CASE FOR Tall Wood BUILDINGS [Yelektronniy resurs] / Michael C Green. $\quad-\quad 2012 . \quad-\quad$ Rezhim dostupu do resursu: www.cwc.ca/documents/.../Tall\%20Wood\%20Buildings\%20-\%20Final\%20Report.pdf.

[6] Ínformatsíyna broshyura Simpson Strong-Tie. Soyediniteli dlya dvutavrovykh balok. A/S C-RUS-2014.

[7] DBN V.2.6-161:2017 Derev`yaní konstruktsiî. Osnovní polozhennya / Mínregíon Ukraïni. - Kï̈v, 2017. - $111 \mathrm{~s}$.

[8] DSTU EN 300:2008. Plity drevesnostruzhechnyye s oriyentirovannoy struzhkoy (OSB). Terminy i opredeleniya ponyatiy, klassifikatsiya i tekhnicheskiye trebovaniya (EN 300:2006, IDT) / Derzhspozhivstandart Ukraïni. - Kiïv, 2011. - 11 s.

\section{НАПРУЖЕНО-ДЕФОРМОВАНИЙ СТАН В' ЯЗОВОГО ВУЗЛА КАРКАСНОГО БАГАТОПОВЕРХОВОГО ДЕРЕВ'ЯНОГО БУДИНКУ}

Гілодо О.Ю., к.Т.н., доцент, ORCID 0000-0001-5387-5538

Aрсірій A.M., к.т.н., доцент, ORCID 0000-0003-3262-1488

Одеська державна академія будівництва та архітектури

\begin{abstract}
Анотація. Каркасне багатоповерхове дерев'яне житлове будівництво стрімко розвивається в багатьох країнах світу. Використання дерев'яних двотаврових балок 3 дерев'яного клеєного бруса і плити OSB (oriental strand board) підвищує ефективність конструктивних рішень. Особливу складність при проектуванні і виготовленні балкових структур в складі багатоповерхових каркасних будинків представляють вузли сполучення балок 3 колонами, які можуть бути шарнірними або податливими. Переважно ці вузли вважають податливими, що забезпечує просторову роботу каркаса i зменшує його
\end{abstract}


деформативність в порівнянні з шарнірними. Як правило, вузли виконуються зі сталевими елементами, які з'єднують балки з колонами за допомогою болтів і нагелів. Телевізори 3 таким конструктивне рішення рамного вузла: прямокутна клеєна колона і ригель у вигляді двотаврової балки з OSB-стінкою і полками з бруса, посиленими клеєної деревиною в опорних зонах. Опорні зони ригелів виконуються суцільного прямокутного перерізу 3 клеєного бруса. Для обпирання ригелів на колону одягається оголовок 3 консолями 3 листової сталі товщиною до 4 мм, 3 отворами для кріплення саморізами. Виліт консолі відповідає ширині опорних зон ригелів. Після закріплення ригелів до консолей опорна зона колони верхнього поверху з'єднується з верхньою полицею ригелів кріпильних елементом у вигляді куточка. Стінка консолі кріпиться до колони, полку консолі кріпиться до нижньої полиці балки. Вертикальні стінки консолі з двох сторін кріпляться до стінки опорної зони балки. Для аналізу напружено-деформованого стану двотаврової балки в програмному комплексі «Ліра-САПР» була розроблена просторова комп'ютерна модель вузла. Напруженодеформований стан балки аналізували по полях переміщень і напружень, а також за деформаціями конструкції. Результати досліджень дозволяють зробити висновок про надійність пропонованого рішення вузла.

Ключові слова: складова дерев'яна балка, пояси з деревини, плита OSB, метод кінцевих елементів, розрахункова модель.

\title{
НАПРЯЖЕННО-ДЕФОРМИРОВАННОЕ СОСТОЯНИЕ СВЯЗЕВОГО УЗЛА КАРКАСНОГО МНОГОЭТАЖНОГО ДЕРЕВЯННОГО ЗДАНИЯ
}

\author{
Гилодо А.Ю., к.т.н., доцент, \\ Арсирий А.Н., к.т.н., доцент, \\ Одесская государственная академия строительства и архитектуры
}

\begin{abstract}
Аннотация. Каркасное многоэтажное деревянное домостроение стремительно развивается во многих странах мира. Использование деревянных двутавровых балок из деревянного клееного бруса и плиты OSB (oriental strand board) повышает эффективность конструктивных решений. Особую сложность при проектировании и изготовлении балочных структур в составе многоэтажных каркасных домов представляют узлы сопряжения балок с колоннами, которые могут быть шарнирными или податливыми. Преимущественно эти узлы считают податливыми, что обеспечивает пространственную работу каркаса и уменьшает его деформативность по сравнению с шарнирными. Как правило, узлы выполняются со стальными элементами, которые соединяют балки с колоннами с помощью болтов и нагелей. Предлагается следующее конструктивное решение рамного узла: прямоугольная клееная колонна и ригель в виде двутавровой балки с OSB-стенкой и полками из бруса, усиленными клееной древесиной в опорных зонах. Опорные зоны ригелей выполняются сплошного прямоугольного сечения из клееного бруса. Для опирания ригелей на колонну одевается оголовок с консолями из листовой стали толщиной до 4 мм, с отверстиями для крепления саморезами. Вылет консоли соответствует ширине опорных зон ригелей. После закрепления ригелей к консолям опорная зона колонны верхнего этажа соединяется с верхней полкой ригелей крепежным элементом в виде уголка. Стенка консоли крепится к колонне, полка консоли крепится к нижней полке балки. Вертикальные стенки консоли с двух сторон крепятся к стенке опорной зоны балки. Для анализа напряженно-деформированного состояния двутавровой балки в программном комплексе «Лира-САПР» была разработана пространственная компьютерная модель узла. Напряженно-деформированное состояние балки анализировали по полям перемещений и напряжений, а также за деформациями конструкции. Результаты исследований позволяют сделать вывод о надежности предлагаемого решения узла.

Ключевые слова: составная деревянная балка, пояса из древесины, плита OSB, метод конечных элементов, расчетная модель.
\end{abstract}




\title{
ВИЗНАЧЕННЯ ГЕОМЕТРИЧНИХ ХАРАКТЕРИСТИК ШПУНТУ ДЛЯ РОЗРАХУНКІВ ДЕФОРМУВАННЯ ТОНКИХ СТІНОК У 2D ПОСТАНОВЦІ
}

\author{
Безушко Д.І., к.т.н., доцент, \\ dibezushko@gmail.com ORCID 0000-0003-2215-1136 \\ Одеський національний морский університет \\ Арсірій O.I., ст. викладачь, \\ elena.arsiriy@gmail.com ORCID 0000-0001-8660-6916 \\ Одеський національний морский університет \\ Іллічов В.Г., к. архітектури, \\ chigi1960@gmail.com \\ Одеський національний морский університет
}

\begin{abstract}
Анотація. Однією 3 найбільш поширених конструктивних схем, що використовуються при будівництві та реконструкції причалів - $є$ тонкі стінки (больверк). Ця система складається з лицьової стінки та анкерної системі, у яку входять тяж та анкерна стінка (або інший вид анкеруючого пристрою). Можливі деякі варіації конструктивної схеми, але в кожну з них входить лицьова стінка $з$ шпунту. У роботі наведено варіанти визначення геометричних характеристик перерізів шпунту для використання у розрахунках плоскої деформації (плоска розрахункова модель). У стандартних сортаментах шпунту наведені лише загальні геометричні характеристики перерізу такі, як площа, момент інерції, момент опору, радіус інерції, але цього замало для використання в розрахунках методом скінченних елементів. Складна форма поперечного перерізу шпунту (зетовий, коритного, прямого, комбінованого та інших видів перерізу) призводить до розбіжностей у визначені геометричних характеристик та їх інтерпретації у плоскій та просторовій постановці визначення напружено-деформованого стану. В роботі наведена методика визначення геометричних характеристик перерізу для стержню, що згинається для плоскої розрахункової моделі. Для розрахунків методом скінчених елементів використовується програний комплекс для геотехнічних розрахунків Midas GTS NX. Використання методу скінченних елементі при визначені геометричних характеристик поперечного перетину шпунту дає відносну похибку до 5\% по відношенню до даних наведених у сортаменті. Що э прийнятним для використання у подальших розрахунках причальних конструкцій. У роботі розглянуто два варіанти для одного метру погонного стінки: в 1 м входить 1 шпунт повністю 600 мм та другий частково 400 мм; в 1 м входять обидва шпунти по 500 мм. Найменше значення моменту інерції отримано для першого варіанту $72511 \mathrm{~cm}^{4}$, що співпадає 3 значенням 3 сортаменту на $-0.26 \%$. А для другого варіанту момент інерції більше на $12 \%$. Тому при розрахунках слід приймати найбільш невигідний варіант.
\end{abstract}

Ключові слова: тонка стінка, больверк, причал, метод скінчених елементів, геометричні характеристики перерізів.

Вступ. Однією 3 найбільш поширених конструктивних схем, що використовуються при будівництві та реконструкції причалів - $\epsilon$ тонкі стінки (больверк). Ця система складається 3 лицьової стінки та анкерної системі, у яку входять тяж та анкерна стінка (або інший вид анкеруючого пристрою). Можливі деякі варіації конструктивної схеми, але в кожну з них входить лицьова стінка з шпунту.

Аналіз досліджень та публікацій. Шпунтова стінка та шпунтова паля працюють на згин, при цьому розрахункова схема всієї конструкції може розглядатися, як плоска деформація [8, 2] так i в тривимірній постановці. Для визначення напруженнодеформованого стану та розрахунку використовують метод скінченних елементів [9] та його 
сучасні інтерпретації [4]. Самі шпунтові палі мають достатньо складну форму поперечного перерізу (зетовий, коритний, прямий, комбінований та інші види перерізу) [6] тому їх інтерпретація у розрахунковій схемі, є достатньо творчою задачею і потребує математичного обгрунтування. У роботі наведено загальні принципи ідеалізації поперечного перетину шпунтових металевих паль для використання в плоских та просторових розрахункових схемах методу скінчених елементів у програному комплексі для геотехнічних розрахунків Midas GTS NX. Це робить роботу актуальною та обумовлює іï практичне використання у реальних розрахунках причальних конструкцій типу тонкі стінки з металевого шпунту.

Метою дослідження - $\epsilon$ розробка алгоритму визначення геометричних характеристик металевого шпунту, для використання в розрахунках причалів типу «больверк» 3 використання методу скінчених елементів у плоскій постановці.

Для досягнення мети дослідження потрібно було вирішити наступні задачі:

1. Побудувати алгоритм визначення геометричних характеристик металевого шпунту y MIDAS GTS NX;

2. Виконати порівняльний аналіз отриманих даних з характеристиками наведеними у сортаменті [6].

Матеріали та методика дослідження. Ідеалізація шпунту при плоскій розрахунковій схемі $2 \mathrm{D}$.

Скінченні елементи, що використовуються при моделюванні 2D [4]:

1. Грунт моделюється елементами плоскої деформації Рис. 1.. Такі елементи використовуються для розрахунків споруд та їх основ, зокрема причалів, гребель і тунелів, коли типовий перетин споруди не змінюється на великій відстані в напрямку нормалі до площини даного перетину. Так як напруження в напрямку товщини елемента існують, напружений стан в таких елементах технічно не є двовимірним.

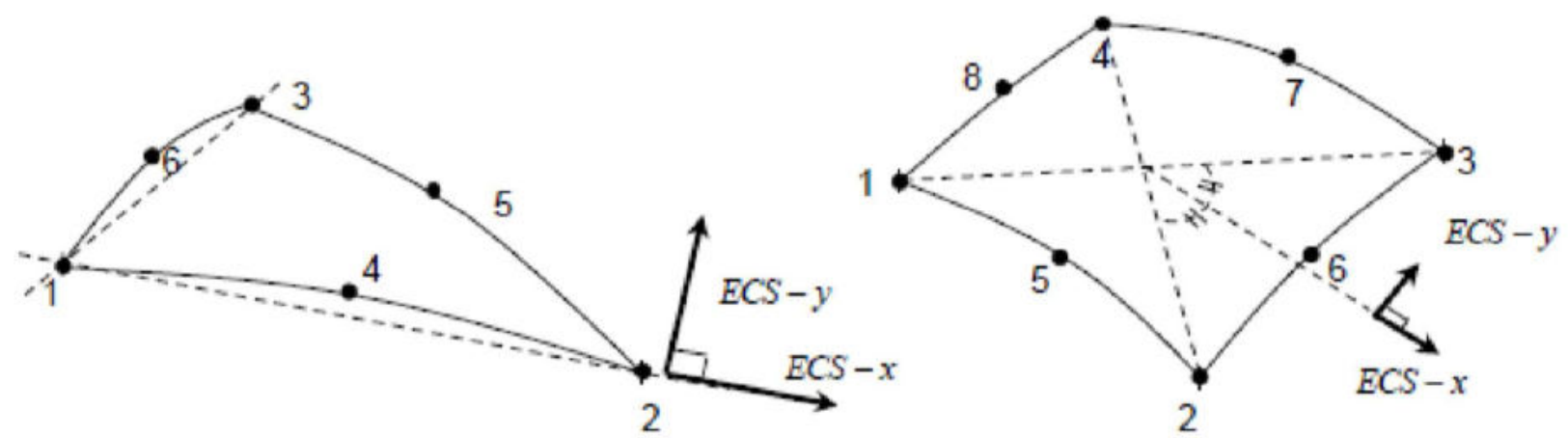

Рис. 1 Система координат елементу плоскої деформації

2. Стінка моделюється балочним елементом для визначення повздовжніх, поперечних сил та моменту, що згинає. На Рис. 2 наведено у графічному виді зусилля, деформації та система координат балочного елементу в загальному виді.

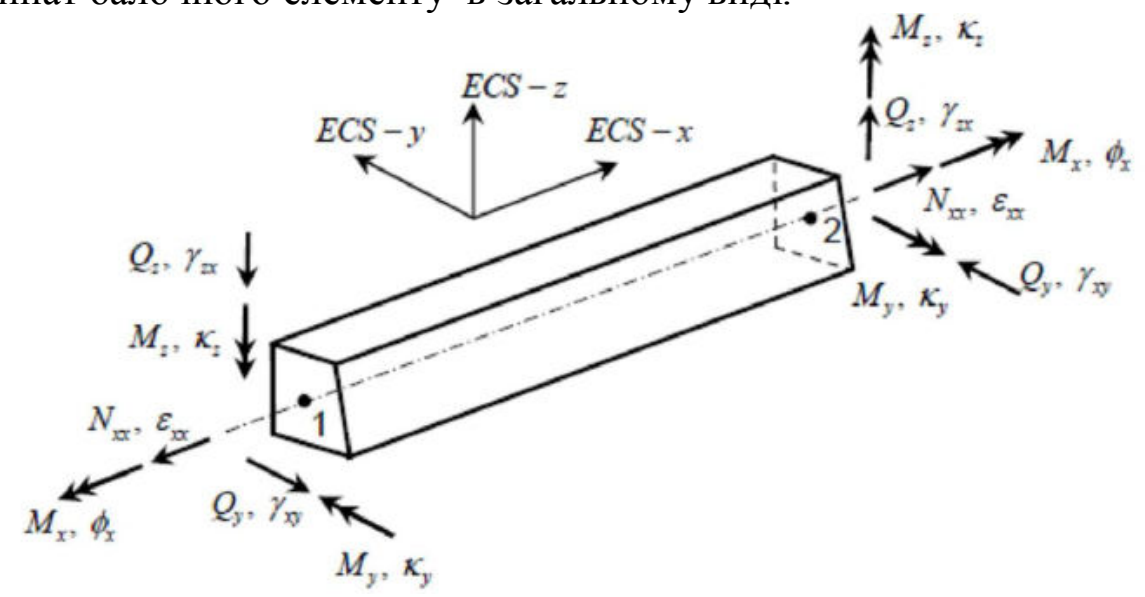

Рис.2. Зусилля, деформації та система координат балочного елементу 


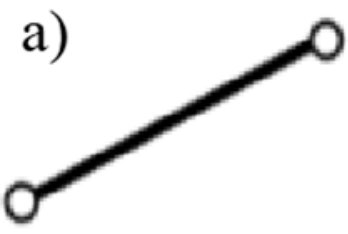

б)

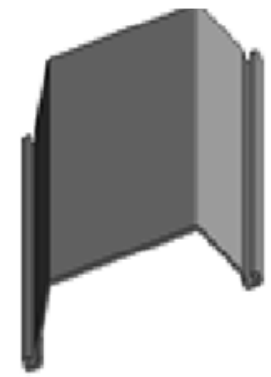

B)

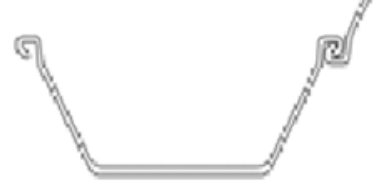

Рис. 3. Фізична та ідеалізована модель шпунту

а) ідеалізована модель, б) фізична модель, в) поперечний перетин стінки.

Сам скінченний елемент має два вузла, відстань між ними характеризує його довжину. Геометричні характеристики перерізу необхідно вводити додатково у форму Create/Modify 1D Property вкладенка Beam Рис.4.

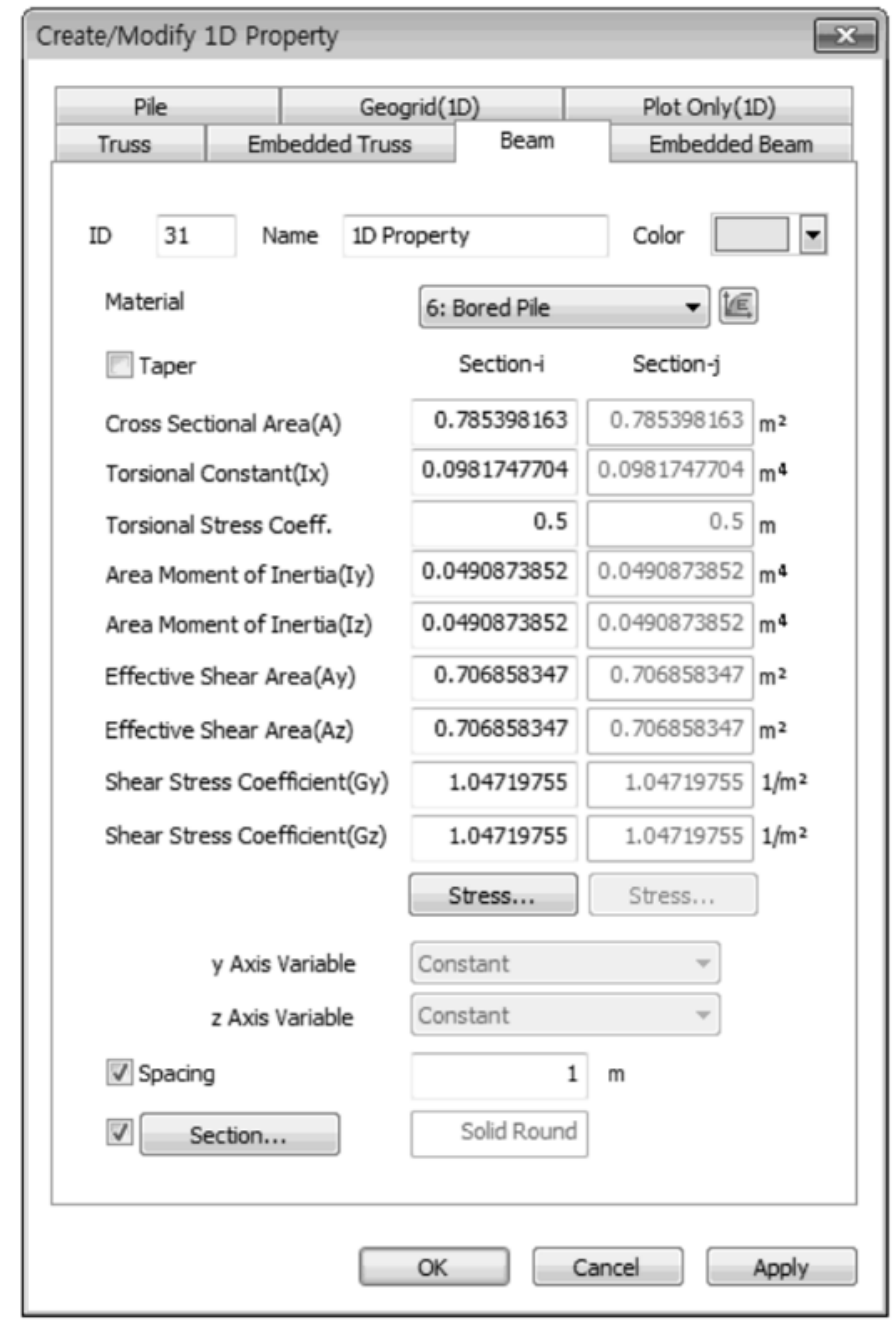

Рис. 4. Форма Create/Modify 1D Property

Cross sectional area (А) (Площа поперечного перерізу).

Torsional stiffness $\left(\mathrm{I}_{\mathrm{xx}}\right)$ (Жорсткість при крученні)

Жорсткість при кручені - це характеристика опору крутному моменту, і обчислюється наступним чином

$$
I_{x x}=\frac{T}{G \theta}
$$

де, $I_{x x}$ - жорсткість при кручені, $T$ - крутний момент, $\theta$ - кут скручування, $\mathrm{G}$ - модуль зсуву. 
Жорсткість при кручені може бути обчислена 3 використанням принципу СенВенана. За умови визначення $\omega$ - функції кручення, методом скінченних елементів, вираз (1) має наступний вигляд

$$
I_{x x}=\int\left[\left(\frac{\partial \omega}{\partial z}+y\right) y-\left(\frac{\partial \omega}{\partial y}-z\right) z\right] d A
$$

Effective shear area (Asy, Asz ) (Ефективна площа зрізу)

Величина ефективної площі зрізу необхідна для обчислення зсувної жорсткості, яка характеризує опір дії поперечній силі. Якщо ефективна площа зрізу по деякому напрямку не задана, то деформації зсуву по даному напрямку ігноруються.

$$
\begin{gathered}
A_{s y}=S_{k y} A \\
A_{s z}=S_{k z} A
\end{gathered}
$$

де, $S_{k y}$ та $S_{k z}$ - коефіцієнт ефективної площі зрізу, що характеризує опір дії поперечній силі в напряму вісі $y$ та z системи координат елемента, $A_{s y}, A_{s z}$ - ефективна площа зрізу, що характеризує опір дії поперечній силі в напрямі вісі $y$ та $z$ у сістеми координат елемента.

Area moment of inertia $\left(I_{y y}, I_{z z}\right)$ (Момент інерції перерізу)

$$
\begin{gathered}
I_{y y}=\int z^{2} d A \\
I_{z z}=\int y^{2} d A
\end{gathered}
$$

Усі геометричні характеристики можна визначати та вводити в ручну, а можна скористатися методом скінченних елементів, та визначити їх за допомогою вбудованого калькулятора геометричних характеристик в Midas GTS NX. Алгоритм дій для шпунту PU32 наведено нижче.

\section{Алгоритм визначення геометричних характеристик перерізу в Midas GTS NX:}

1. Імпорт абрису поперечного перерізу. Для цього використовуємо електронну базу даних перерізів шпунту з сайту виробника у форматі $\mathrm{dxf}$ [7], або будуємо у ручну за допомогою геометричних примітивів.

2. Перевірка геометричних розмірів та масштабування моделі. У зв’язку з тим що поперечний перетин в dxf файлі виконано в міліметрах, а розміри моделі в GTS NX прийнято в метрах, нам необхідно масштабувати модель з коефіцієнтом масштабу 0.001 .

3. Побудова поверхні по грані.

4. Введення характеристик матеріалу (модуль деформацій, коефіцієнт поперечних деформацій, питома вага).

5. Формування властивостей скінченного елементу, для формування поперечного перерізу. Будемо використовувати оболонкові скінченні елементи.

6. Формування мережі скінченних елементів.

7. Визначення геометричних характеристик поперечного перетину шпунту за допомогою вбудованого калькулятора в GTS NX Рис.5.

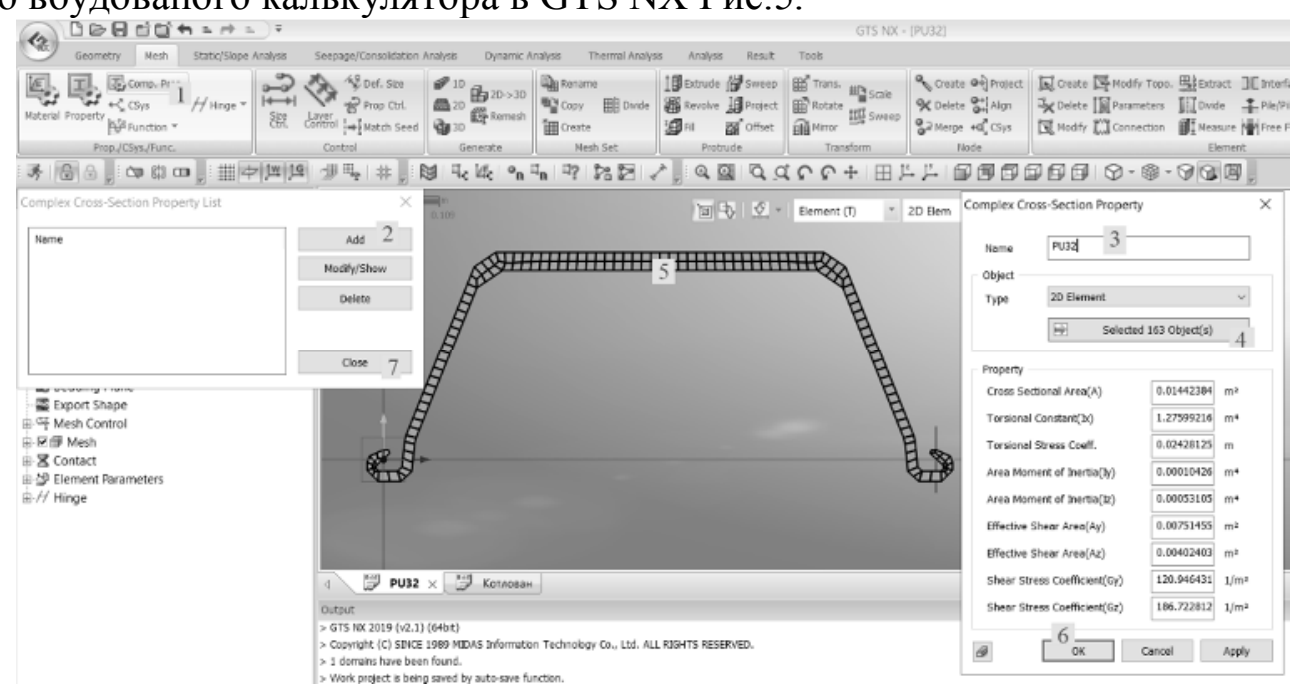

Рис. 5. Визначення геометричних характеристик поперечного перетину 
9. Формування властивостей поперечного перетину для завдання параметрів скінченному елементу типу балка Рис.6.

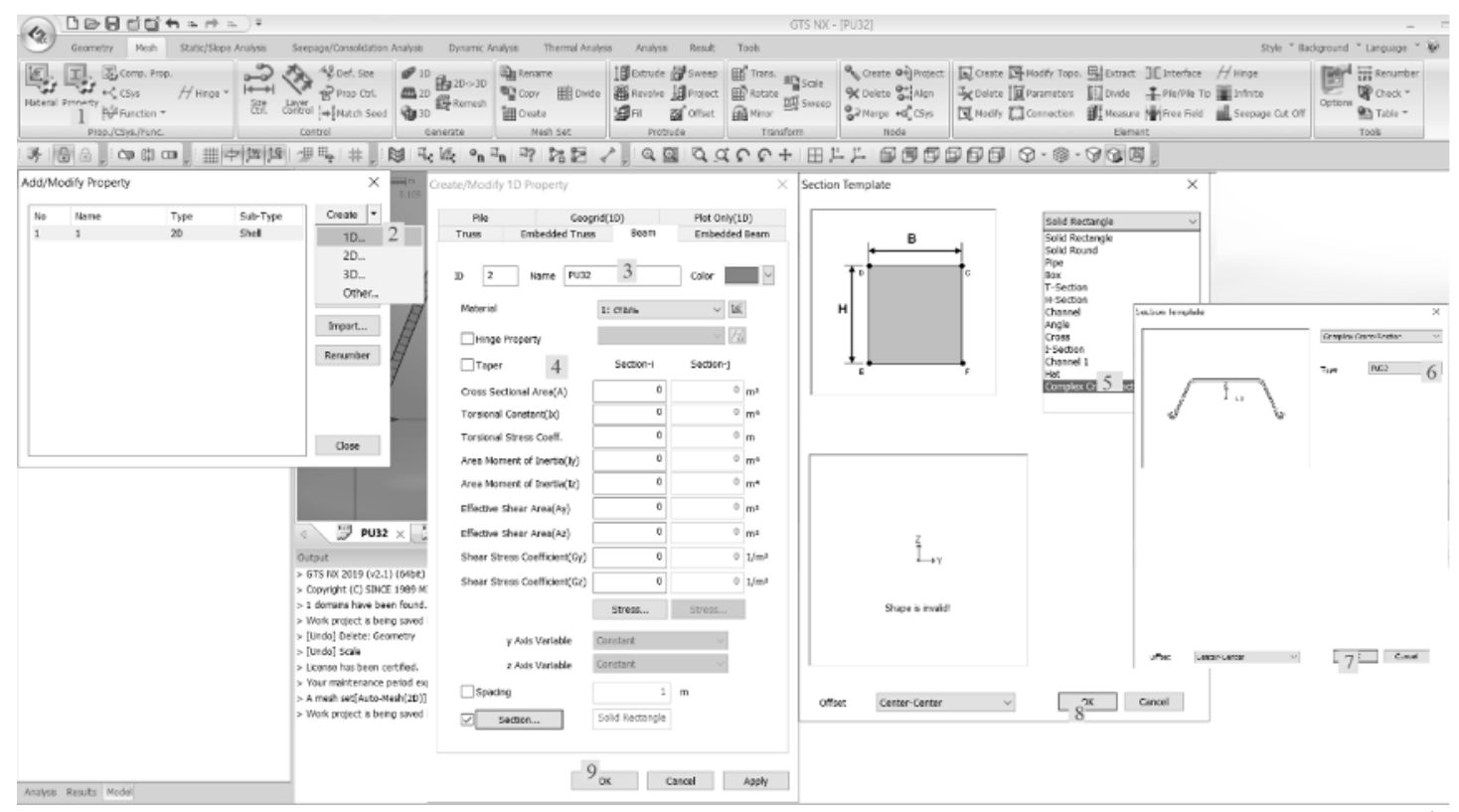

Рис. 6. Формування властивостей поперечного перетину для завдання параметрів скінченному елементу типу балка.

При використанні плоскої розрахункової схеми слід умовно вирізати 1 м.п. причалу, але який саме слід вирішувати інженеру. У роботі розглянуто два варіанти: в 1 м входить 1 шпунт повністю 600 мм та другий частково 400 мм Рис. 7 а; в 1 м входять обидва шпунти по 500 мм. Рис. 7 б.

\section{Аналіз отриманих результатів.}

Для аналізу та можливості використання отриманніх данних будемо порінювати їх 3 данними, що наведені в сартаменті шпунту фірми ArcelorMittal [6]. Порівнювати будемо дві геометричні характеристики $\boldsymbol{A}$ (площу) та $\boldsymbol{I}$ (момент інерції) для чотирьох варіантів поперечного перерізу: один шпунт, два шпунти, 1метр стінки (як показано на Рис. 7 а) та 1метр стінки (як показано на Рис. 7 б).

Результати визначення геометричних характеристик перерізу та визначення відносних відхилень наведені у Таблиця 1.

a)

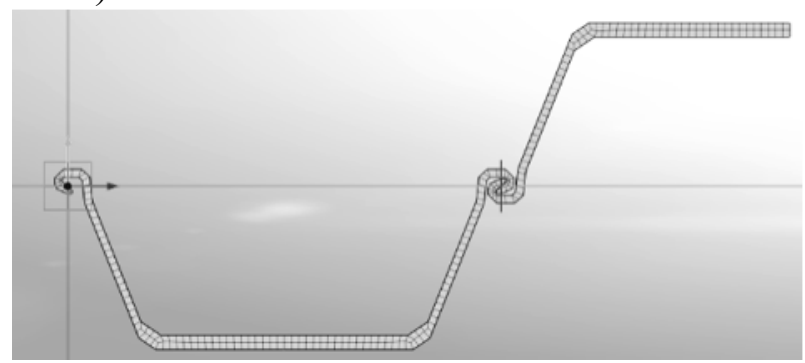

б)

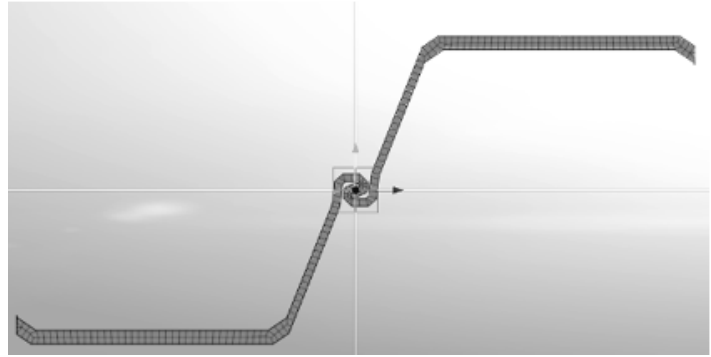

Рис. 7. Можливі вид поперечного перерізу на 1 м стінки 
Порівняння отриманих результатів 3 даними сортаменту для PU32

\begin{tabular}{|c|c|c|c|c|c|c|}
\hline \multirow{2}{*}{ Профіль } & \multicolumn{2}{|c|}{ Відповідно до [6] } & \multicolumn{2}{|c|}{$\begin{array}{c}\text { За результатами } \\
\text { розрахунку }\end{array}$} & \multicolumn{2}{c|}{ Відносне відхилення } \\
\cline { 2 - 7 } & $\begin{array}{c}\text { Площа, } \\
\text { см }^{2}\end{array}$ & $\begin{array}{c}\text { Момент } \\
\text { інерції } I \\
\text { см }^{4}\end{array}$ & $\begin{array}{c}\text { Площа, } \\
\text { см }^{2}\end{array}$ & $\begin{array}{c}\text { Момент } \\
\text { інерції } I \\
\text { см }^{4}\end{array}$ & $\%$ & $\%$ \\
\hline для S & 145.4 & 10950 & 144.2 & 10426 & 0.83 & 4.79 \\
\hline для D & 290.8 & 86790 & 288.5 & 87059 & 0.79 & -0.31 \\
\hline $\begin{array}{c}\text { для 1 м } \\
\text { стінки } \\
\text { рис. 7 а }\end{array}$ & 242.3 & 72320 & 234.9 & 72511 & 3.05 & -0.26 \\
\hline $\begin{array}{c}\text { для 1 м } \\
\text { стінки } \\
\text { рис. 7 б }\end{array}$ & 242.3 & 72320 & 224.8 & 80773 & 7.22 & -11.69 \\
\hline
\end{tabular}

\section{Висновки.}

1. Використання методу скінченних елементі при визначені геометричних характеристик поперечного перетину шпунту дає відносну похибку до 5\% по відношенню до даних наведених у сортаменті. Що э прийнятним для використання у подальших розрахунках причальних конструкцій.

2. У роботі розглянуто два варіанти для одного метру погонного стінки: в 1 м входить 1 шпунт повністю 600 мм та другий частково 400 мм Рис. 14 а; в 1 м входять обидва шпунти по 500 мм. Найменше значення моменту інерції отримано для першого варіанту $72511 \mathrm{~cm}^{4}$, що співпадає з значенням з сортаменту на -0.26\%. А для другого варіанту момент інерції більше на 12\%. Тому при розрахунках слід приймати найбільш невигідний варіант.

\section{Список літератури}

1. Ворожцов Е. В. Разностные методы решения задач механики сплошных сред: Учеб. пособие. - Издательство НГТУ - Новосибирск, 1998. - 86с.

2. ДБН В.2.1-10-2009 Основи та фундаменти споруд. М.: Мінрегіонбуд України,2009

3. Клованич, С. Ф., Безушко Д.И. Метод конечных элементов в нелинейных расчетах пространственных железобетонных конструкций. - Одесса: ОНМУ, 2009, 93с.

4. Пособие по расчетам GTS NX - електронне видання [Режим доступу: http://ru.midasuser.com/web/page.php?no=65].

5. Ренгач В.Н. Шпунтовые стенки. Расчет и проектирование. Издательство литературы по строительству: Ленинград, 1970, 106с.

6. Стальные шпунтовые сваи. Общий каталог 2018. - ArcelorMittal, 2018. - 64. [Режим доступу:

https://sheetpiling.arcelormittal.com/wpcontent/uploads/2017/10/AMCRPS General_Catalogue GB 2019 web.pdf]

7. AutoCad files. The full range of ArcelorMittal's steel sheet piles 2019 [Режим доступу: https://sheetpiling.arcelormittal.com/download-center/autocad-files/]

8. Fedorovsky V.G., Kolesnikov Yu. M, Kurillo S.V., Levachev S.N. Piles in Hydrotechnical Engineering. - CRC Press, 2002. - 264p.

9. Zienkiewicz O. C. The finite element method. - Megrow-Hill Book Company (UK) Limited, 1986. -787 p. 


\title{
References
}

1. Vorozhtsov Ye. V. Raznostnyye metody resheniya zadach mekhaniki sploshnykh sred: Ucheb. posobiye. - Izdatel'stvo NGTU - Novosibirsk, 1998. - 86s.

2. DBN V.2.1-10-2009 Osnovi ta fundamenti sporud. M.: Mínregíonbud Ukraïni,2009

3. Klovanich, S. F., Bezushko D.I. Metod konechnykh elementov v nelineynykh raschetakh prostranstvennykh zhelezobetonnykh konstruktsiy. - Odessa: ONMU, 2009, 93s.

4. Calculation Guide GTS NX - Electronic View [Access Mode: http://ru.midasuser.com/web/page.php?no=65].

5. Rengach V.N. Shpuntovyye stenki. Raschet i proyektirovaniye. Izdatel'stvo literatury po stroitel'stvu: Leningrad, 1970, 106s.

6. Steel sheet piles. General catalog 2018. - ArcelorMittal, 2018. - 64. [Access mode: https://sheetpiling.arcelormittal.com/wp-

content/uploads/2017/10/AMCRPS_General_Catalogue_GB 2019_web.pdf].

7. AutoCad files. The full range of ArcelorMittal's steel sheet piles 2019 [Режим доступу: https://sheetpiling.arcelormittal.com/download-center/autocad-files/]

8. Fedorovsky V.G., Kolesnikov Yu. M, Kurillo S.V., Levachev S.N. Piles in Hydrotechnical Engineering. - CRC Press, 2002. - 264p.

9. Zienkiewicz O. C. The finite element method. - Megrow-Hill Book Company (UK) Limited, 1986. -787 p.

\section{ОПРЕДЕЛЕНИЕ ГЕОМЕТРИЧЕСКИХ ХАРАКТЕРИСТИК ШПУНТОВ ДЛЯ РАСЧЕТОВ ДЕФОРМИРОВАНИЯ ТОНКИХ СТЕНОК В 2D ПОСТАНОВКЕ}

\author{
Безушко Д.И., к.т.н., доцент, \\ dibezushko@gmail.com ORCID 0000-0003-2215-1136 \\ Одесский национальный морской университет \\ Арсирий Е.И., cm. преподователь, \\ elena.arsiriy@gmail.com ORCID 0000-0001-8660-6916 \\ Одесский национальный морской университет \\ Ільичев В.Г., к. архитектуры, \\ chigi1960@gmail.com \\ Одесский национальный морской университет
}

Аннотация. Одной из наиболее распространенных конструктивных схем, используемых при строительстве и реконструкции причалов - есть тонкие стенки (больверк). Эта система состоит из лицевой стенки и анкерной системе, в которую входят тяж и анкерная стенка (или другой вид анкерующей устройства). Возможны некоторые вариации конструктивной схемы, но в каждой из них входит лицевая стенка с шпунта. В работе приведены варианты определения геометрических характеристик сечений шпунта для использования в расчетах плоской деформации (плоская расчетная модель). В стандартных сортамент шпунта приведены лишь общие геометрические характеристики сечения такие, как площадь, момент инерции, момент сопротивления, радиус инерции, но этого мало для использования в расчетах методом конечных элементов. Сложная форма поперечного сечения шпунта (зетовый, корытного, прямого, комбинированного и других видов сечения) приводит к разногласиям в определенные геометрических характеристик и их интерпретации в плоской и пространственной постановке определения напряженно-деформированного состояния. В работе приведена методика определения геометрических характеристик сечения для стержню, что сгибается для плоской расчетной модели. Для расчетов методом конечных элементов используется проигран комплекс для геотехнических расчетов Midas GTS NX. Использование метода конечных элементе при определении геометрических характеристик поперечного сечения шпунта дает относительную погрешность до 5\% по отношению к 
данным приведенных в сортаменте. Что э приемлемым для использования в дальнейших расчетах причальных конструкций. В работе рассмотрены два варианта для одного метра погонного стенки: в 1 м входит 1 шпунт полностью 600 мм и второй частично 400 мм; в 1 м входят оба шпунты по 500 мм. Наименьшее значение момента инерции получено для первого варианта 72511 см4, что совпадает со значением с сортамента на $-0.26 \%$. А для второго варианта момент инерции больше на $12 \%$. Поэтому при расчетах следует принимать наиболее невыгодный вариант.

Ключевые слова: тонкая стенка, больверк, причал, метод конечных элементов, геометрические характеристики сечений.

\title{
DETERMINATION OF GEOMETRIC CHARACTERISTICS OF WINGS FOR CALCULATIONS OF THIN WALL DEFORMATION IN 2D PRODUCTION
}

\author{
Bezushko D., Ph.D., Assistant Professor \\ dibezushko@gmail.com ORCID 0000-0003-2215-1136 \\ Odessa National Maritime University \\ Arsirii E., Senior lecturer \\ elena.arsiriy@gmail.com ORCID 0000-0001-8660-6916 \\ Odessa National Maritime University \\ Illichov V., Ph.D., \\ chigi1960@gmail.com \\ Odessa National Maritime University
}

\begin{abstract}
One of the most common structural schemes used in the construction and reconstruction of berths - is a thin wall (bolverk). This system consists of a front wall and an anchor system, which includes a string and an anchor wall (or other type of anchoring device). There are some variations of the design scheme, but each of them includes a front wall of sheet piling. The paper presents options for determining the geometric characteristics of sheet piles for use in the calculations of flat deformation (flat design model). In the standard assortments of sheet piling, only the general geometrical characteristics of the section such as area, moment of inertia, moment of resistance, radius of inertia are given, but this is not enough for use in finite element calculations. The complex shape of the cross-section of the sheet pile (zeta, trough, straight, combined and other types of cross-section) leads to differences in the definition of geometric characteristics and their interpretation in the flat and spatial formulation of the stress-strain state. The paper presents a method for determining the geometric characteristics of the cross section for a bending rod for a flat design model. For finite element calculations, the lost complex for geotechnical calculations Midas GTS NX is used. The use of the finite element method in determining the geometric characteristics of the cross section of the sheet pile gives a relative error of up to $5 \%$ relative to the data given in the range. What is acceptable for use in further calculations of berth structures. The paper considers two options for one meter of the running wall: $1 \mathrm{~m}$ includes 1 tongue completely $600 \mathrm{~mm}$ and the second partially $400 \mathrm{~mm}$; in $1 \mathrm{~m}$ both sheet piles on $500 \mathrm{~mm}$ enter. The lowest value of the moment of inertia was obtained for the first variant $72511 \mathrm{~cm} 4$, which coincides with the value from the range by $-0.26 \%$. And for the second option, the moment of inertia is more than $12 \%$. Therefore, the calculations should take the most unfavorable option.
\end{abstract}

Keywords: thin wall, bollard, berth, finite element method, geometric characteristics of sections. 


\title{
ПРИМЕНЕНИЕ ДЕРЕВЯННЫХ ДВУТАВРОВЫХ БАЛОК С УЗЛАМИ ИЗ СТАЛЬНЫХ ТРУБЧАТЫХ ЭЛЕМЕНТОВ В КОНСТРУКЦИЯХ КРУЖАЛЬНО- СЕТЧАТЫХ СВОДОВ
}

Бояджи А.А., к.т.н., старший преподаватель, mdipk4@gmail.com, ORCID: 0000-0002-9987-7974

Бойко А.В., к.т.н., ассистент, Одесская государственная академия строительства и архитектуры boikoolv@gmail.com, ORCID: 0000-0003-1762-9932

Стоянов B.O., к.т.н., ООО «ЦНИПС ЛДК»

stoianov.kdk@gmail.com, ORCID:0000-0002-7578-7472

\begin{abstract}
Аннотация. В статье авторы исследуют вопрос применения в конструкциях кружально-сетчатых сводов деревянных двутавровых балок со стальными трубчатыми узлами. Деревянные двутавровые балки давно доказали свою эффективность и в настоящее время широко применяются в конструкциях перекрытий и покрытий простых форм, однако их применение в конструкциях криволинейных и полигональных ограничено недостаточным количеством проработанных вариантов таких узлов. В статье авторы приводят возможный вариант такого узла и исследуют его напряженно-деформированное состояние в работе кружально-сетчатого свода пролетом 12 метров.

Ключевые слова: кружально-сетчатый свод, деревянная двутавровая балка, стальные трубчатые элементы, нагрузка, напряженно-деформированное состояние.

Введение. Древесина - быстро возобновляемый, экологичный материал с высокой удельной прочностью, который все чаще используется в строительстве современных зданий и сооружений. Деревянные двутавровые балки (ДДБ) давно доказали свою эффективность и в настоящее время широко применяются в конструкциях перекрытий и покрытий простых прямолинейных форм. Существенным минусом применения ДДБ является недостаточное количество проработанных узлов их соединения.
\end{abstract}

Анализ последних исследований и публикаций. Раннее в статье [1] авторы приводили конструкцию и анализ напряженно-деформированного состояния подобного узла, применяемого в полигональных арочных конструкциях. Кроме того, в настоящей работе использовались исследования в области конструирования и расчета кружально-сетчатых сводов профессоров Стоянова В.В., Карлсена Г.Г., Кагана М.Е. и других [2-4].

В конструкциях кружально-сетчатых сводов широко используется перекрестный узел системы Цольбау [2-4], который состоит из одинаковых дощатых элементов (косяков), поставленных на ребро и идущих по двум пересекающимся направлениям. В зависимости от поперечного сечения покрытия (круговая дуга или ломаная линия вписанного в нее правильного многоугольника) верхняя кромка элементов (косяков) может быть кривой (по эллипсу) или ломаной.

Наиболее близким к представленному в статье узлу является перекрестный узел, который применяется в кружально-сетчатом своде системы Пасельника, в котором не используются стальные элементы [2-4]. Перекрестный узел содержит три косяка, которые объединяются, при этом два набегающих косяка входят с обеих сторон своими шипами в гнездо сквозного косяка.

Существенным недостатком узлов системы Цольбау и Пасельника является недостаточная прочность (жесткость) узла.

Конструкция перекрестного узла системы Пасельника выбрана прототипом при разработке представленного в статье узла. 
Целью работы является разработка эффективных и компактных узлов соединения ДДБ, работающих в конструкциях кружально-сетчатых сводов, исследование напряженнодеформированного состояния таких узлов и влияния их применения на НДС элементов конструкции и несущей способности конструкции в целом.

Методы исследования. В работе применялись аналитические методы строительной механики, а также численные расчеты, основанные на методе конечных элементов, реализованный в программных комплексах ЛИРА-САПР 2016 (предварительный расчет конструкции) и ANSYS Workbench 19.

Основной материал и результаты исследований. Наличие в конструкции узла стальных закладных элементов и усиливающих накладок может существенно повысить его несущую способность и жесткость. Благодаря геометрической форме закладных стальных элементов распределение нагрузки становится более равномерным, что уменьшает напряжения в несущих элементах.

Новое конструктивное решение перекрестного узла двутавровых деревянных балок комбинированных элементов-оболочек предусматривает использование главного и двух дополнительных перекрестных несущих деревянных стыковых элементов (рис. 1), в которых предусмотрены два трехлучевые закладные элементы и две усиливающие накладки. Следует отметить, что главный и дополнительные перекрестные несущие элементы выполнены в виде деревянных двутавровых балок, а закладные элементы и усиливающие накладки изготовлены из металла. Трехлучевые закладные элементы закреплены в несущих двутавровых деревянных балках таким образом, что: одна часть каждого из этих элементов расположена в главной двутавровой деревянной балке и соединена с соответствующей усиливающей накладкой; вторая часть каждого из них расположена в условно первом дополнительном перекрестном несущем элементе; третья часть каждого из этих элементов расположена в условно втором дополнительном перекрестном несущем элементе.

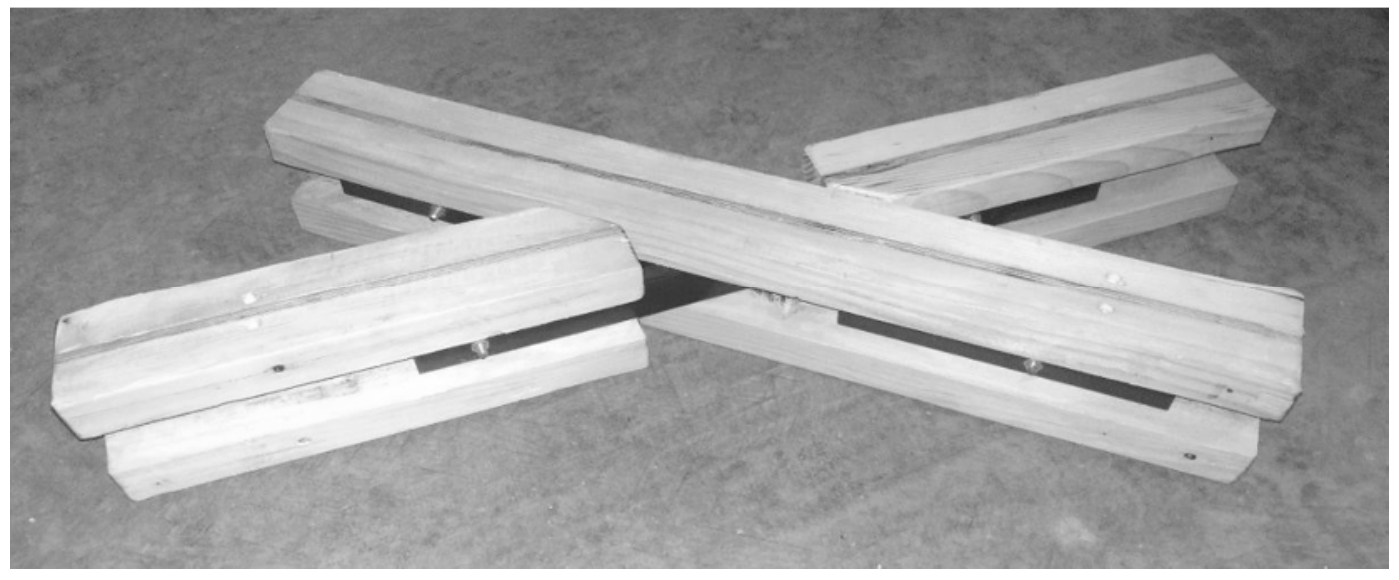

Рис. 1. Перекрестный узел двутавровых деревянных балок

Технический результат существенного укрепления перекрестного узла двутавровых деревянных балок достигается благодаря:

1. выполнению главного и дополнительных несущих элементов в виде двутавровых деревянных балок;

2. наличии металлических закладных элементов и усиливающих накладок;

3. получению нового геометрического очертания закладных элементов.

Перекрестный узел (рис. 2) двутавровых деревянных балок комбинированных элементов-оболочек выполняется с применением следующих элементов:

1 - главная двутавровая деревянная балка комбинированных элементов-оболочек;

2, 3 - две перекрещивающиеся двутавровые деревянные балки;

4, 5 - два закладных трехлучевых элемента;

6, 7 - две усиливающие накладки. 

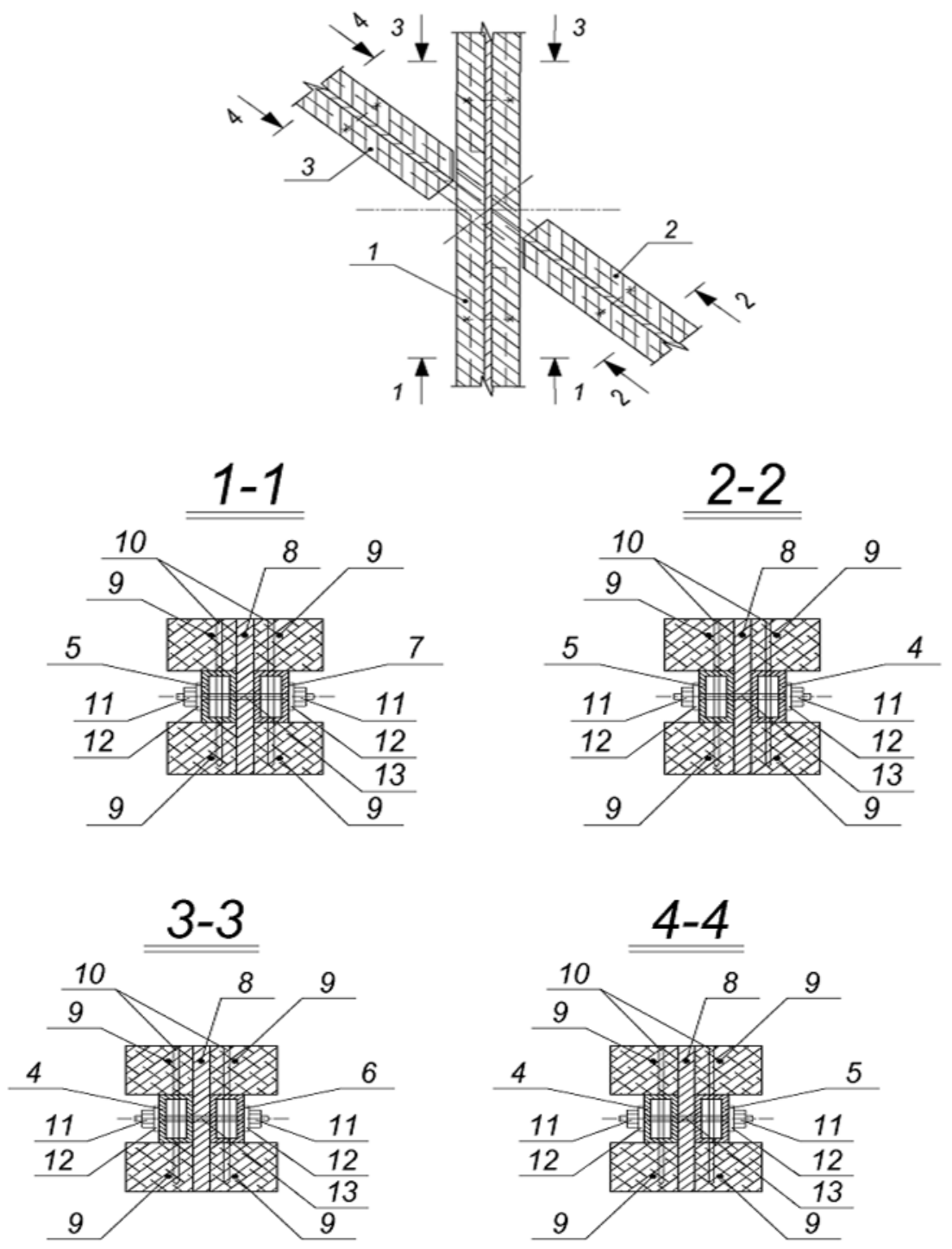

Рис. 2 Перекрестный узел двутавровых деревянных балок комбинированных элементов-оболочек

Применение деревянных двутавровых балок в качестве элементов кружально-сетчатых сводов (КСС) позволит существенно облегчить их конструкцию, а применение легких узлов упростить процесс их возведения.

Что касается конструкции КСС, то она не является такой простой, как кажется на первый взгляд. Геометрический расчет такой пространственной конфигурации является достаточно сложным.

В статье приведен расчет сегмента сомкнутого свода на прямоугольном плане с цилиндрической поверхностью. В основной части сегмента возможно использование типовых косяков ввиду ее регулярности. Обычно, косяки, примыкающие к криволинейным ребрам, имеют нестандартную длину и, соответственно, индивидуальные конструктивные решения, их длины определяются по координатам точек пересечения осей регулярной сетки и криволинейного ребра.

Для уменьшения трудоемкости, рассмотренная конструкция была спроектирована из одинаковых по длине косяков, соединенных стальными прямоугольными трубами.

Пролет рассматриваемой конструкции составляет 18 метров, высота в замке - 3 метра. Кружально-сетчатый свод состоит из одинаковых прямолинейных косяков двутаврового сечения (рис. 3), соединенных под прямым углом и длина которых составляет 1515 мм. 

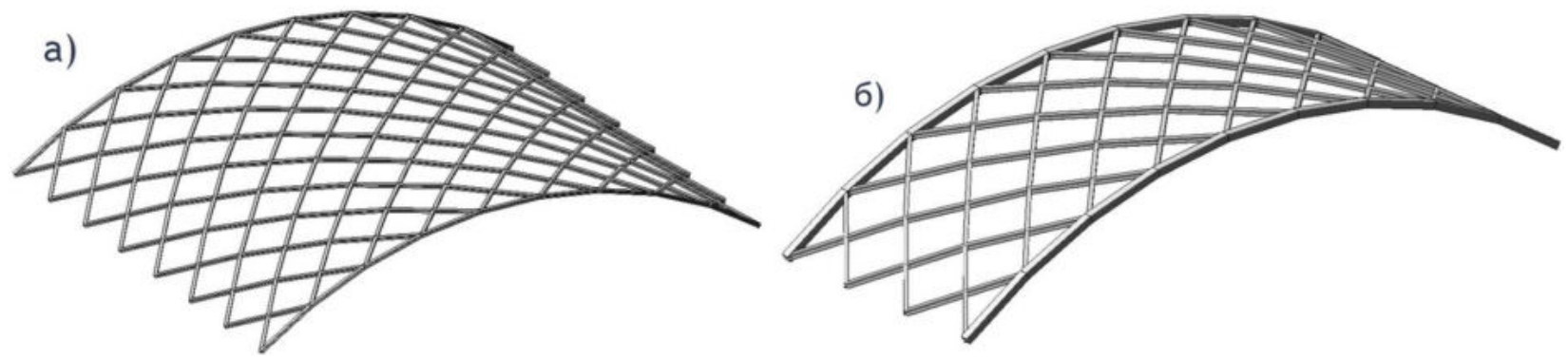

Рис. 3 Схема КСС в ПК “ЛИРА-САПР” з показаними поперечними перетинами елементів довжиною: а) 15 м; б) 6,42 м

Рассмотренный КСС набирается из деревянных двутавровых балок с OSB-стенкой следующих размеров: высота балки 120 мм; высота поясов 40 мм; ширина пояса 90 мм; толщина стенки из OSB 10 мм.

Расчет в ПК "ЛИРА-САПР". Значения усилий в элементах конструкций были приняты для расчета по методу эквивалентного (приведенного) сечения, предложенного в ДБН [5]. При расчете косяков не учитывается крутящий момент, влияние которого на несущую способность КСС существенно уменьшается за счет работы обшивки, которая чаще всего применяется в реальных конструкциях. Расчет для них ведется как для сжатоизогнутых элементов (точнее, сжатых элементов с косым изгибом), поскольку изгибающий момент косяков возникает по двум осям. Поскольку приведенная гибкость косяков превышает значение 0,3 (1), напряжение в них определяются с учетом коэффициентов устойчивости (2), (3).

$$
\begin{aligned}
& \lambda_{\text {rel }, y}=\frac{\lambda_{y}}{\pi} \sqrt{\frac{f_{c, 0, k}}{E_{0,05}}}=\left(l_{\text {ef }} /\right.\left.\pi \cdot \sqrt{\frac{I_{e f, \text { inst }}}{A_{\text {ef }, \text { inst }}}}\right) \times \sqrt{\frac{3 \cdot f_{c, 0, k}}{2 \cdot E_{0, \text { mean }}}}=(151,5 / 3,14 \sqrt{1311 / 80,8}) \times \\
& \times \sqrt{\frac{3 \cdot 2}{2 \cdot 1000}}=0,656>0,3
\end{aligned}
$$

Коэффициенты продольного изгиба определяются по формулам:

$$
k_{y}=0,5\left(1+\beta_{c}\left(\lambda_{r e l, y}+0,3\right)+\lambda_{r e l, y}^{2}\right)=0,5\left(1+0,1 \cdot(0,656+0,3)+0,656^{2}\right)=0,733
$$

где $\beta_{c}=0,1$ для клееной древесины и LVL;

$$
k_{c, y}=\frac{1}{k_{y}+\sqrt{k_{y}^{2}-\lambda_{r e l, y}^{2}}}=\frac{1}{0,733+\sqrt{0,733^{2}-0,656^{2}}}=0,944 ;
$$

Расчет показал, что наибольшие напряжения в конструкции длиной 15 м возникают у соединительного узла конструкции в месте максимального момента в плоскости косяка и составляют:

$$
\begin{gathered}
\frac{\sigma_{c, 0, d}}{k_{c, y} f_{c, 0, d}}+\frac{\sigma_{m, y, d}}{f_{m, y, d}}+k_{m} \frac{\sigma_{m, z, d}}{f_{m, z, d}}=\frac{N_{c o o m s}}{A_{e f, \text { inst }} k_{c, y} f_{c, 0, d}}+\frac{M_{y, \max }}{W_{e f, y, \text { inst }} f_{m, y, d}}+\frac{M_{z, \max }}{W_{e f, z, \text { inst }} f_{m, y, d}}= \\
=\frac{9,63}{80,8 \cdot 1,08}+\frac{3,84 \cdot 100}{218,5 \cdot 1,18}+\frac{0,528 \cdot 100}{147,3 \cdot 1,18}=1,9>1
\end{gathered}
$$




$$
\begin{aligned}
f_{c, 0, d} & =k_{\bmod } \frac{f_{c, 0, k}}{\gamma_{m}}=0,7 \cdot \frac{2}{1,3}=1,08 \kappa H / \mathrm{cm}^{2} ; \\
f_{m, y, d} & =k_{\mathrm{mod}} \frac{f_{m, k^{a}}}{\gamma_{m}}=0,7 \cdot \frac{2,2}{1,3}=1,18 \kappa H / \mathrm{cm}^{2} ;
\end{aligned}
$$

Что касается КСС длиной 6,24 м, то:

$$
\begin{gathered}
\frac{\sigma_{c, 0, d}}{k_{c, y} f_{c, 0, d}}+\frac{\sigma_{m, y, d}}{f_{m, y, d}}+k_{m} \frac{\sigma_{m, z, d}}{f_{m, z, d}}=\frac{N_{c o o m s}}{A_{e f, \text { inst }} k_{c, y} f_{c, 0, d}}+\frac{M_{y, \max }}{W_{e f, y, \text { inst }} f_{m, y, d}}+\frac{M_{z, \max }}{W_{e f, z, \text { inst }} f_{m, y, d}}= \\
=\frac{7,23}{80,8 \cdot 1,08}+\frac{2,49 \cdot 100}{218,5 \cdot 1,18}+\frac{0,18 \cdot 100}{218,5 \cdot 1,18}=1,152>1 ;
\end{gathered}
$$

Максимальные вертикальные перемещения под действием расчетной нагрузки возникают около четверти пролета КСС со стороны большей нагрузки у соединительного узла конструкции и составляют по величине: $f_{\max }=-67$ мм для конструкции длиной 15 м; $f_{\max }=-63$ мм для - 6,24 м, что в обоих случаях превышает, но близко к допустимым значениям прогибов, которые составляют 60 мм.

Расчет в ПК "ANSYS". Для расчета конструкция КСС, состоящяя из 1001 объемного элемента (378 деревянных, 180 OSB и 443 стальных элементов), была разбита на 526000 КЭ. На перемещения левых и правых опор конструкции были наложены ограничения по всем трем осям. Ветровая нагрузка задавалась в виде давления, нормального к поверхности конструкции, а снеговая нагрузка - в виде распределенной по верхней поверхности косяков. Покрытие в расчет не введено, поэтому несущая способность конструкции будет несколько занижена.

Максимальные перемещения при несимметричной загрузке составляют 59,89 мм. Прогиб (перемещение по оси Ү) составляет 52,82 мм, что удовлетворяет предельным значениям (согласно ДБН Деревянные конструкции [5]) и чуть ниже перемещений, полученных линейным расчетом. Это можно объяснить большей жесткостью расчетной схемы, в которую в качестве соединительных элементов входят стальные трубы.

Наибольшие напряжения в деревянных элементах конструкции (рис. 4) возникают в косяках, близких к середине длины конструкции и опорам - составляют 8,6 МПа.

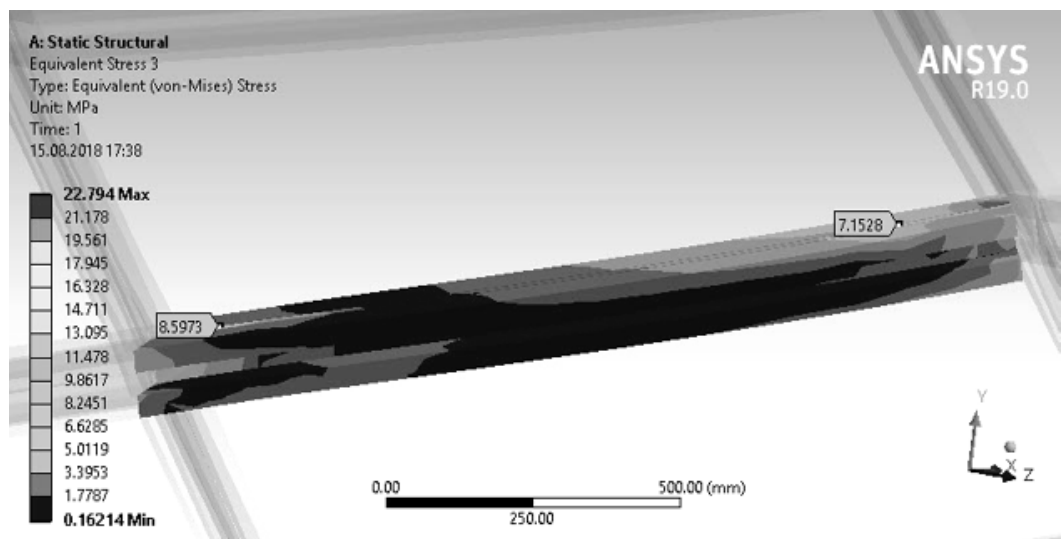

Рис. 4 Эквивалентные напряжения в деревянных элементах конструкции

$$
\sigma_{f, \text { inst },, \text {, max }, d}=0,86 \kappa H / \mathrm{cm}^{2}<k_{c} f_{c, 0, d}=1,08 \kappa H / \mathrm{cm}^{2} ;
$$

Наибольшие напряжения в стальной трубе (рис. 5) возникают в смежном, наиболее напряженном элементе узла (рис. 5) и составляют 204,5 МПа. 


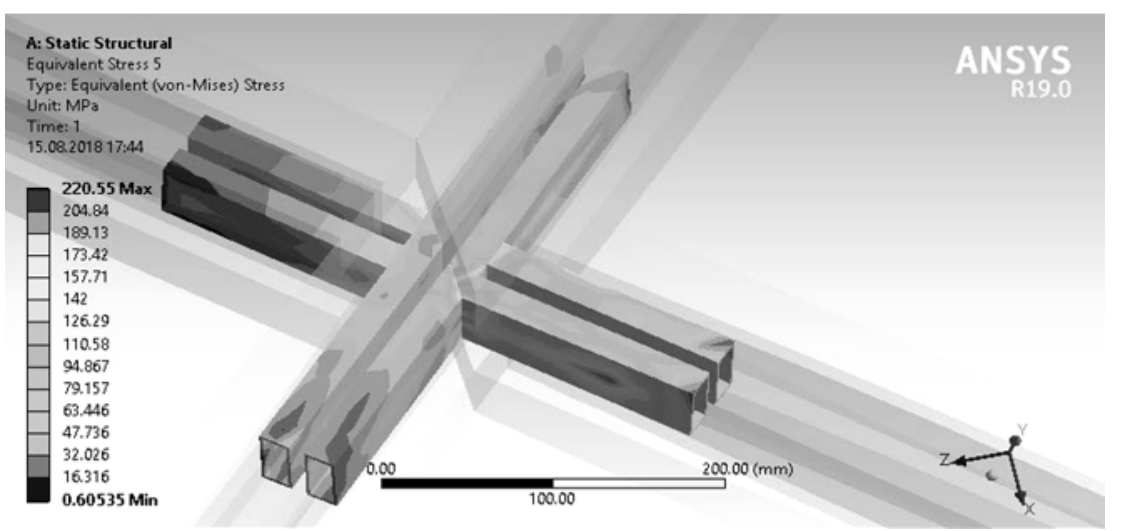

Рис. 5 Эквивалентные напряжения в стальной трубе соединительного узла конструкции

$$
\begin{gathered}
\left(\frac{N}{A_{n} R_{y} \gamma_{c}}\right)^{n}+\frac{M_{x}}{c_{x} W_{x n, \min } R_{y} \gamma_{c}}+\frac{M_{y}}{c_{y} W_{y n, \min } R_{y} \gamma_{c}} \leq 1 ; \\
\frac{\sigma_{e q}}{R_{y} \gamma_{c}}=\frac{20,45}{24 \cdot 0,9}=0,95<1
\end{gathered}
$$

Наибольшие напряжения возникают в опорном узле (рис. 6). Напряжения сконцентрированы на небольшой площади, и их значение составляет 150 МПа.

$$
\frac{\sigma_{e q}}{R_{y} \gamma_{c}}=\frac{15}{24 \cdot 0,9}=0,7<1
$$

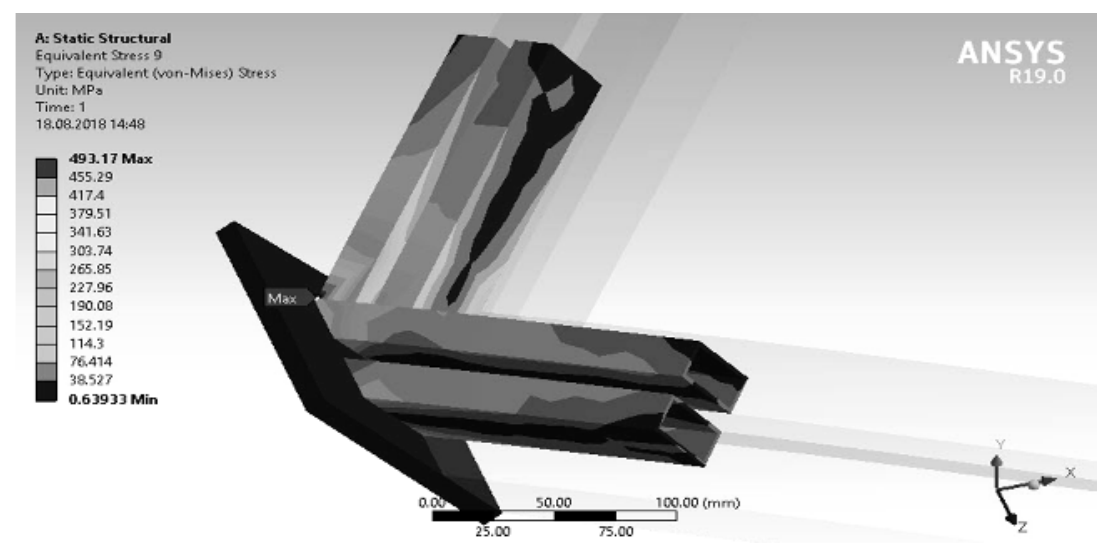

Рис. 6 Эквивалентные напряжения

в стальной трубе соединительного узла конструкции

Выводы. Из расчетов в ПК "ANSYS WORKBENCH" и "ЛИРА-САПР" видно, что введение в расчет элементов соединений (стальных труб) существенно влияет на напряженно-деформированное состояние конструкции в целом за счет не только увеличения геометрических характеристик и несущей способности в узлах, а также, возможно, за счет работы этих элементов в качестве ребер жесткости, которые уменьшают деформацию деревянных двутавров и принимают на себя действие крутящего момента, в следствие того, что они являются сечениями замкнутого контура. За счет такой работы напряжение в соединительных элементах более чем в 10 раз выше, чем в ДДБ, что приемлемо и, более того, позволяет более полно использовать возможности материала, из которого они изготовлены - стали. 


\section{Литература}

1. Експериментальні дослідження полігональної аркової конструкції / Стоянов В.В., Коршак О.М., Бояджі А. А., Бойко О.В.. // Сучасні будівельні конструкції з металу, деревини та пластмас. - 2018. - №22. - С. 50-59.

2. Карлсен Г. Г. Конструкции из дерева и пластмасс / Г. Г. Карлсен, В. В. Большаков, М. Е. Каган. - Москва: Стройиздат, 1975. - 686 с.

3. Стоянов В. В. Конструирование легких сборных гиперболических покрытий / Владимир Васильевич Стоянов. - Одесса: Укртехснаб, 2000. - 164 с.

4. Журавлев А. А. Пространственные деревянные конструкции / А. А. Журавлев, Г. Б. Вержбовский, Н. Н. Еременко. - Ростов-на-Дону: Ростов-на-Дону, 2003. - 504 с.

5. ДБН В.2.6 - 161:2017. Дерев’яні конструкції. Норми проектування. - [чинні від 2015-01-01]. - К.: Мінрегіон України, 2017. - 117 с. (Державні будівельні норми України).

6. ДБН В.1.2-2:2006. Навантаження і впливи. Норми проектування. - [чинні від 200701-01]. - К.: Мінбуд України, 2006. - 75 с. (Державні будівельні норми України).

7. ДБН В.1.2-14:2018. Система забезпечення надійності та безпеки будівельних об'єктів. Загальні принципи забезпечення надійності та конструктивної безпеки будівель і споруд. - [чинні від 2019-01-01]. - К.: Мінрегіон України, 2018. - 30 с. (Державні будівельні норми України).

\section{References}

[1] Eksperymentalni doslidzhennia polihonalnoi arkovoi konstruktsii / Stoianov V.V., Korshak O.M., Boiadzhi A. A., Boiko O.V.. // Suchasni budivelni konstruktsii z metalu, derevyny ta plastmas. -2018 .

[2] Karlsen H. H. Konstruktsyy yz dereva y plastmass / H. H. Karlsen, V. V. Bolshakov, M. E. Kahan. - Moskva: Stroiyzdat, 1975.

[3] Stoyanov V. V. Konstruirovanie legkikh sborny'kh giperbolicheskikh pokry`tij / Vladimir Vasil'evich Stoyanov. - Odessa: Ukrtekhsnab, 2000.

[4] Zhuravlev A. A. Prostranstvenny`e derevyanny`e konstrukczii / A. A. Zhuravlev, G. B. Verzhbovskij, N. N. Eremenko. - Rostov-na-Donu: Rostov-na-Donu, 2003.

[5] DBN V.2.6-198:2014. Stal'nyye konstruktsii. Normy proyektirovaniya [chynni vid 2015-0101]. K.: Minrehion Ukrainy, 2014.

[6] DBN V.1.2-2:2006. Navantazhennia i vplyvy. Normy proyektirovaniya [chynni vid 2007-0101]. K.: Minbud Ukrainy, 2006.

[7] DBN V.1.2-14:2018. Systema zabezpechennya nadiynosti ta bezpeky budivel'nykh ob"yektiv. Zahal'ni pryntsypy zabezpechennya nadiynosti ta konstruktyvnoyi bezpeky budivel' $i$ sporud [chynni vid 2019-01-01]. K.: Minrehion Ukrainy, 2018.

\section{ЗАСТОСУВАННЯ ДЕРЕВ'ЯНИХ ДВОТАВРОВИХ БАЛОК 3 ВУЗЛАМИ 3 ТРУБЧАСТИХ СТАЛЕВИХ ЕЛЕМЕНТІВ У КОНСТРУКЦІЯХ КРУЖАЛЬНО- СІТЧАСТИХ СКЛЕПІННЬ}

Бояджі А.О., к.т.н., старший викладач, mdipk4@gmail.com, ORCID: 0000-0002-9987-7974

Бойко А.В., к.т.н., асистент, Одеська державна академія будівництва та архітектури boikoolv@gmail.com, ORCID: 0000-0003-1762-9932

Стоянов B.О., к.т.н., ТОВ «ЦНДПС ЛДК» stoianov.kdk@gmail.com, ORCID: 0000-0002-7578-7472 
Анотація. У статті автори досліджують питання застосування в конструкціях кружальної-сітчастих склепінь дерев'яних двотаврових балок зі сталевими трубчастими вузлами. Дерев'яні двотаврові балки (ДДБ) давно довели свою ефективність і в даний час широко застосовуються в конструкціях перекриттів i покриттів простих форм, однак застосування в конструкціях криволінійних i полігональних ускладнене в зв'язку 3 відсутністю опрацьованих вузлів їх з'єднань. У статті автори наводять можливий варіант такого вузла, досліджують його напружено-деформований стан (НДС) в роботі кружальносітчастого склепіння прольотом 12 метрів.

Метою роботи $\epsilon$ розробка ефективних і компактних вузлів з'єднання ДДБ, що працюють в конструкціях кружально-сітчастих склепінь, дослідження напруженодеформованого стану розробленого вузла, впливу його застосування на НДС елементів конструкції і несучої здатності конструкції в цілому.

В роботі було проведено аналіз існуючих на тему досліджень, 3 якого було видно, що найбільш близьким до представленого в статті вузлу $\epsilon$ перехресний вузол, який застосовується в кружальної-сітчастому склепінні без використання сталевих елементів, системи Пасельніка. Перехресний вузол містить три косяки, що з'єднуються, при цьому два набігаючих косяки входять по обидва боки своїми шипами в гніздо наскрізного косяку.

Застосування дерев'яних двотаврових балок в якості елементів кружальної-сітчастих склепінь (КСС) дозволить істотно полегшити їх конструкцію, а застосування легких вузлів спростити процес їх зведення.

Проліт розглянутої конструкції становить 18 метрів, висота в замку - 3 метри. Кружальної-сітчасте склепіння складається з однакових прямолінійних косяків двотаврового перетину, з'єднаних під прямим кутом і довжина яких становить 1515 мм.

Розглянутий КСС набирається 3 дерев'яних двотаврових балок 3 OSB стінкою наступних розмірів: висота балки 120 мм; висота поясів 40 мм; ширина поясу 90 мм; товщина стінки з OSB 10 мм.

3 розрахунків в ПК "ANSYS WORKBENCH" і "ЛІРА-САПР" отримано, що введення в розрахунок елементів з'єднань (сталевих труб) істотно впливає на напружено-деформований стан конструкції в цілому за рахунок не тільки збільшення геометричних характеристик і несучої здатності в вузлах, а також, можливо, за рахунок роботи цих елементів в якості ребер жорсткості, які зменшують деформацію дерев'яних двутавров і приймають на себе дію крутного моменту, в наслідок того, що вони є перерізами замкнутого контуру. За рахунок такої роботи напруження в сполучних елементах більш ніж в 10 разів вище, ніж в ДДБ, що $\epsilon$ прийнятним i, більш того, дозволяє більш повно використовувати можливості матеріалу, 3 якого вони виготовлені - сталі.

Ключові слова: кружально-сітчасте склепіння, дерев'яна двотаврова балка, сталеві трубчасті елементи, навантаження, напружено-деформований стан.

\title{
DESIGNS OF LAMELLA ROOF WITH WOODEN I-BEAMSAND NODES OF TUBULAR ELEMENTS
}

\author{
Boiadzhi A.O., Ph.D., Senior lecturer \\ mdipk4@gmail.com, ORCID: 0000-0002-9987-7974 \\ Boyko A.V., Ph.D., assistant, \\ Odessa State Academy of Civil Engeeneering and Architecture \\ boikoolv@gmail.com, ORCID: 0000-0003-1762-9932 \\ Stoyanov V.V., Ph.D., \\ «CSRIPS LDK» \\ stoianov.kdk@gmail.com, ORCID: 0000-0002-7578-7472
}

\footnotetext{
Abstract. In the article, the authors investigate the issue of the use of wooden I-beams with steel tubular nodes in the designs of lamella roof. Wooden I-beams have been proven to be effective 
and now the are widely used in the construction of floors and coatings of simple shapes, however, the use in curved and polygonal structures is complicated due to the lack of developed nodes of their connections. In the article, the authors give a possible version of such a node, examine its stress-strain state in the work of a circular-mesh arch with a span of 12 meters.

The aim of the work is to develop efficient and compact nodes of the wooden I-beams connection working as a part of lamella roof, to study the stress-strain state (SSS) of the developed node, the impact of its application on the SSS of structural elements and the bearing capacity of all the structure.

The closest to the node presented in the article is the cross node, which is used in a lamella roof of the Paselnik system (without the use of steel elements). The cross node contains three jambs, which are combined, while two oncoming jambs enter on both sides with their spikes in the through jamb socket.

The use of wooden I-beams as elements of the lamella roof will significantly facilitate their design, and the use of light nodes will simplify the process of their construction.

The span of the structure under consideration is 18 meters, the height in the lock is 3 meters. The lamella roof consists of identical rectilinear jambs of the I-wooden beam, connected at right angles and whose length is $1515 \mathrm{~mm}$.

The considered lamella roof is assembled from wooden I-beams made of OSB with a wall of the following sizes: beam height $120 \mathrm{~mm}$; belt height $40 \mathrm{~mm}$; belt width $90 \mathrm{~mm}$; OSB wall thickness $10 \mathrm{~mm}$.

The calculations in the "ANSYS WORKBENCH" and "LIRA-SAPR" software systems shows that the introduction into the calculation of the elements of the joints (steel pipes) significantly affects the stress-strain state of the all structure due to not only an increase in geometric characteristics and bearing capacity in nodes, but also, possibly, due to the work of these elements as stiffeners, which reduce the deformation of wooden I-beams and take on the action of torque, due to the fact that they are sections of a closed loop. Due to this work, the voltage in the connecting elements is more than 10 times higher than in the wooden I-beams, which is acceptable and, moreover, allows you to more fully use the capabilities of the material from which they are made - steel.

Keywords: lamella roof, wooden I-beam, steel tubular elements, load, stress-strain state. 


\section{ТЕХНОЛОГІЧНІСТЬ РОБІТ ЗАБЕЗПЕЧЕННЯ ВТОРИННОГО ЗАХИСТУ МЕТАЛОКОНСТРУКЦЙ ВІД КОРОЗІЇ В УМОВАХ ХІМІЧНО АКТИВНИХ СЕРЕДОВИЩ}

Гібаленко О.М., д.т.н., професор, grin196102@gmail.com, ORCID:0000-0003-2979-5225

Гібаленко В. А., к.т.н., доцент, vita.ktn@gmail.com, ORCID: 0000-0001-5590-6641

Бочарова О.А., ст. викладач, kaleriabocharova@gmail.com, ORCID:0000-0003-3993-5842 ДВНЗ «Приазовський державний технічний університет»

Анотація. Дослідження спрямовані на визначення ознак корозійного руйнування, умов моніторингу та діагностики технічного стану металоконструкцій за рівнем корозійної небезпеки будівельного об'єкта. У роботі розглянуто експлуатаційний стан конструкцій гранчастої несучої вежі димової труби. Використано принципи процесного підходу для реалізації завдань управління терміном служби металоконструкцій в корозійних агресивних середовищах. Розглянуті заходи забезпечення довговічності у відповідності нормативним вимогам за рівнем корозійної небезпеки будівельного об'єкта, який визначає критичні показники засобів захисту металоконструкцій в умовах режиму корозійних впливів в межах граничних значень.

Ключові слова: дефекти; корозійна небезпека; технологічність, несуча вежа; протикорозійне покриття; процесний підхід; надійність.

Вступ. Оцінка дійсного технічного стану металоконструкцій, експлуатація яких відбувається в корозійно-агресивних середовищах промислових підприємств, вимагає необхідності розвитку методичного підходу, який передбачає комплексне урахування параметрів дійсного стану споруд та факторів режиму експлуатації $[1,2]$. Системний опис процесу діагностики за критерієм забезпечення заходів первинного та вторинного захисту від корозії дозволяє здійснити виконання програми реконструкції на основі технічного моніторингу [3].

Вибір схеми діагностики та відновлення протикорозійної стійкості стрижневих конструкцій i ̈̈х захисних покриттів розглянуто як багатофакторне завдання. Сучасний рівень розвитку методів розрахунку і проектування конструкцій, різноманіття можливих схем і прийомів підвищення несучої здатності та довговічності дозволяють розробити загальний підхід до оптимізації процедури відновлення металоконструкцій та оновлення протикорозійного захисту. Все це передбачає розробку технологічних і проектних рішень за певною схемою з наперед заданим параметрам і при відомих впливах середовища.

Аналіз останніх досліджень і публікацій. Для контролю технічного стану будівель і споруд в процесі їх зведення, реконструкції, ремонту та експлуатації передбачено виконання сукупності цілеспрямованих дій технічної діагностики з використанням у тому числі неруйнівних методів контролю, заснованих на новітніх досягненнях науки і техніки $[4,5,6]$. Питання діагностики технічного стану металоконструкцій будівель і споруд вимагають врахування впливу різних експлуатаційно-виробничих факторів для визначення дійсного стану і прогнозування терміну служби $[7,8]$.

Основне завдання досліджень спрямовано на забезпечення процедури перевірки, визначення стану в якому об'єкт знаходиться в даний час. При цьому розглядаються способи реалізації перевірки - програмний та апаратний. Засобами реалізації програмного способу перевірки виступають як робочі експертні процедури, так і спеціально створені тестові 
прийоми [9]. Апаратний спосіб полягає у використанні для діагностики вбудованих, стаціонарних або зовнішніх, мобільних технічних засобів. У практиці діагностики технічного стану застосовуються обидва методи спільно, так як результат впливів за заданою програмою не може бути замінений використанням приладового або апаратного забезпечення.

Принципи управління корозійної небезпекою експлуатованих об'єктів включають керуючу, нормативну, контролюючу i інвестиційно-технологічну складові безаварійної експлуатації будівель і споруд в умовах агресивних кліматичних та технологічних впливів [10]. Використання раціональних заходів протикорозійного захисту металоконструкцій забезпечує можливість зниження, приблизно на чверть, щорічних експлуатаційних витрат (пов'язаних із забезпеченням надійності і довговічності) тільки за рахунок вдосконалення організації робіт із захисту від корозії [11].

Виділення не розв'язаних раніше частин загальної проблеми. 3 позицій апарату будівельної механіки, допустиме зниження несучої здатності елементів для заданої системи протикорозійного захисту конструкцій (СПЗК) можна враховувати в розрахунках за граничними станами за допомогою фіктивних зовнішніх навантажень $[12,13]$. Сутність передбачених досліджень полягає в обгрунтуванні умов моніторингу та діагностики ознак корозійної небезпеки при технічному обслуговуванні будівельних металоконструкцій по фактичному стану[11].

Згідно з нормативними положеннями встановлюються вимоги до процедури виявлення дефектів і пошкоджень, а також вжиття необхідних заходів для підтримки працездатного стану конструкцій $[14,15]$. Запропонований підхід включає основні наступні етапи оцінки рівня ризику 3 технологічної безпеки: призначення методів контролю параметрів конструкцій за показниками пошкоджуваності i допустимим інтервальним значенням ремонтопридатності; кількісну оцінку показників на підставі розрахунку конструкцій на корозійну стійкість і довговічність; аналіз рівня вразливості конструкцій в залежності від ступеня критичності (категорії дефектів і пошкоджень); оцінку загроз (категорії технічного стану) при експлуатації за фактичним станом при встановлених значеннях ремонтопридатності; впровадження заходів відновлення експлуатаційних властивостей, продовження ресурсу сталевих конструкцій і зниження ризику при реалізації заходів програм забезпечення надійності (ПЗН) по фактичному стану [6].

Постановка завдання. Дійсний стан об'єкта представляється структурною схемою, яка описує стан в кожен момент часу $\mathrm{t}$ з значенням Fi - вхідних, INi - внутрішніх і вихідних OP1 координат, при цьому вхідні і внутрішні - змінні, а вихідні - функції. Графічне представлення процесу діагностики при виконанні процедури моніторингу корозійного стану представлено на рисунку 1.

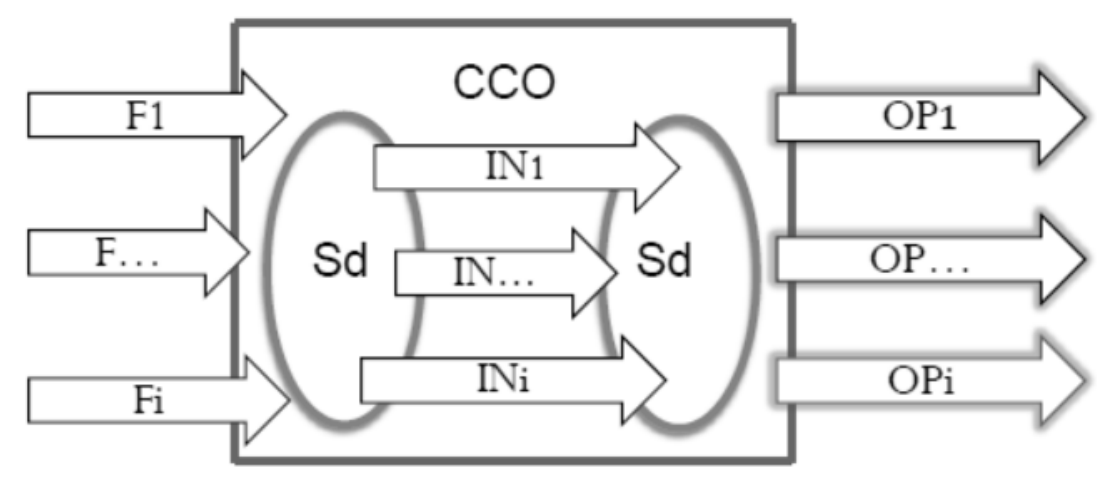

Рис.1. Схема процесу діагностики дійсного корозійного стану об'єкта дослідження. 
Умовний розподіл об'єкта дослідження (ССО) на компоненти пов'язано 3 низкою об'єктивних умов і суб'єктивних передумов. У якості компоненти М - предмета діагностики корозійного стану (ПДКС) вибираються конструкції, елементі, вузли, сполучення які становлять окремі самостійні системи або елементи (балки, колони, сходи, огорожі, елементи каркаса або інженерно-технологічного обладнання, оснащення т.п.). Об'єкт контролю, як логічна система, задається графічно, аналітично, у формі таблиць, фізичною моделлю або у інший віртуальній формі, яка $\epsilon$ зручною для обробки методами комп'ютерно-інженерної технології.

Незалежно від форми компонента М визначаються вихідні параметри і внутрішні взаємні зв'язки, які описують стан споруди. Побудова програми визначення дійсного стану стосується аналізу структури об'єкта дослідження ПДКС як в справному, так і в несправному станах первинного і вторинного захисту від корозії.

Формалізація процесу аналізу обумовлює необхідність опису виявлених дефектів, пошкоджень, недосконалостей існуючих та тих, що прогнозуються. Аналіз структурної схеми при наявності несправностей спрощується, якщо заздалегідь відомі функції, що реалізуються компонентами 3 пошкодженнями. Для визначення цих функцій у справних компонентах навмисно вводиться несправність. Введення і визначення вхідних функцій несправних компонентів відбувається шляхом перерахування можливих несправностей (дефекти і пошкодження захисних покриттів, зміна геометричних характеристик в результаті корозійного зносу, фактори агресивності середовища, значення корозійної стійкості конструктивної форми і матеріалу) або визначення логічних несправностей компонента (деформація огороджувальних конструкцій внаслідок корозійного зносу, погіршення декоративних властивостей, деформації несучих конструкцій, збільшення технологічного навантаження і т.п.).

Основний матеріал і результати. Умовно, об'єкт описується станом з L компонентів. Якщо Si - число можливих одиничних несправностей ј-го компонента, то загальне число М можливих несправностей об'єкта ПДКС буде:

- при одиничних несправностях (один несправний компонент має одну несправність);

$$
M 1=\sum_{j=1}^{L} S j
$$

- при одиничних несправностях компонентів і кратних несправностях об'єкта (один або кілька несправних компонентів мають по одній несправності):

$$
M 2=\prod_{i-1}^{L}(1+S j)-1
$$

- при кратних несправностях компонента і кратних несправностях об'єкта (один несправний компонент має одну несправність);

$$
M 2=\prod_{i-1}^{L}(1+S j)-1
$$

- при кратних несправностях компонента і кратних несправностях об'єкта (один несправний компонент має одну несправність);

$$
M 3=2^{M 1}-1
$$

При реалізації справним об'єктом його технологічної функції, визначається можливість досягнення несправного стану ПДКС. При цьому реалізуються функції, а також спосіб проведення діагностики стану первинного та вторинного захисту від корозії, і складається таблиця функцій несправностей, виконується обгрунтування складу і структури параметрів корозійної стійкості конструкцій для керування технологічною безпекою шляхом зниження 
Сучасні будівельні конструкиії з металу та деревини, 2020. - Вип. № 24

(стор. 28-35) ризиків, що зменшує ймовірність корозійного руйнування і обмежує можливий збиток при запобіганні досягнення конструкціями і споруди граничного стану.

Вплив зовнішніх факторів (агресивне середовище) i внутрішніх параметрів (конструктивна форма) на показники надійності будівельних конструкцій розглянуто для зон розташування груп однорідних конструктивних елементів (з урахуванням виду та інтенсивності корозійних впливів), при цьому основним показником агресивних середовищ $\epsilon$ характеристичній значення річних корозійних втрат $\mathrm{A}_{\mathrm{n}}, \Gamma / \mathrm{M}^{2}$ рік, умовно приведене до незахищеної поверхні стали класу С 235 [15].

Виконані дослідження властивостей лакофарбових покриттів встановили показники якості вторинного захисту від корозії металевих конструкцій гранчастої башти вежі, що обумовлені зовнішніми впливами режиму експлуатації і які залежить, в першу чергу, від ступеня агресивності середовища (табл. 1, 2). Облік електрохімічної кінетики корозійного руйнування в змін міцності проводиться на основі фізичних моделей, що характеризують зміни геометричних параметрів та властивостей матеріалу в часі при агресивних впливах середовищ [13].

Відповідно до викладеного підходу сформульовані вимоги до визначення фактичних значень корозійної агресивності впливів за даними контролю контрольного нормативу $\mathrm{K}_{\mathrm{p}}$ експлуатації об'єктів, що визначає ефективність заходів програми забезпечення надійності на підставі моніторингу показників якості СПЗК при технічному обслуговуванні по фактичному стану[14].

Таблиця 1 - Результати випробування зразків локальних дільниць покриття

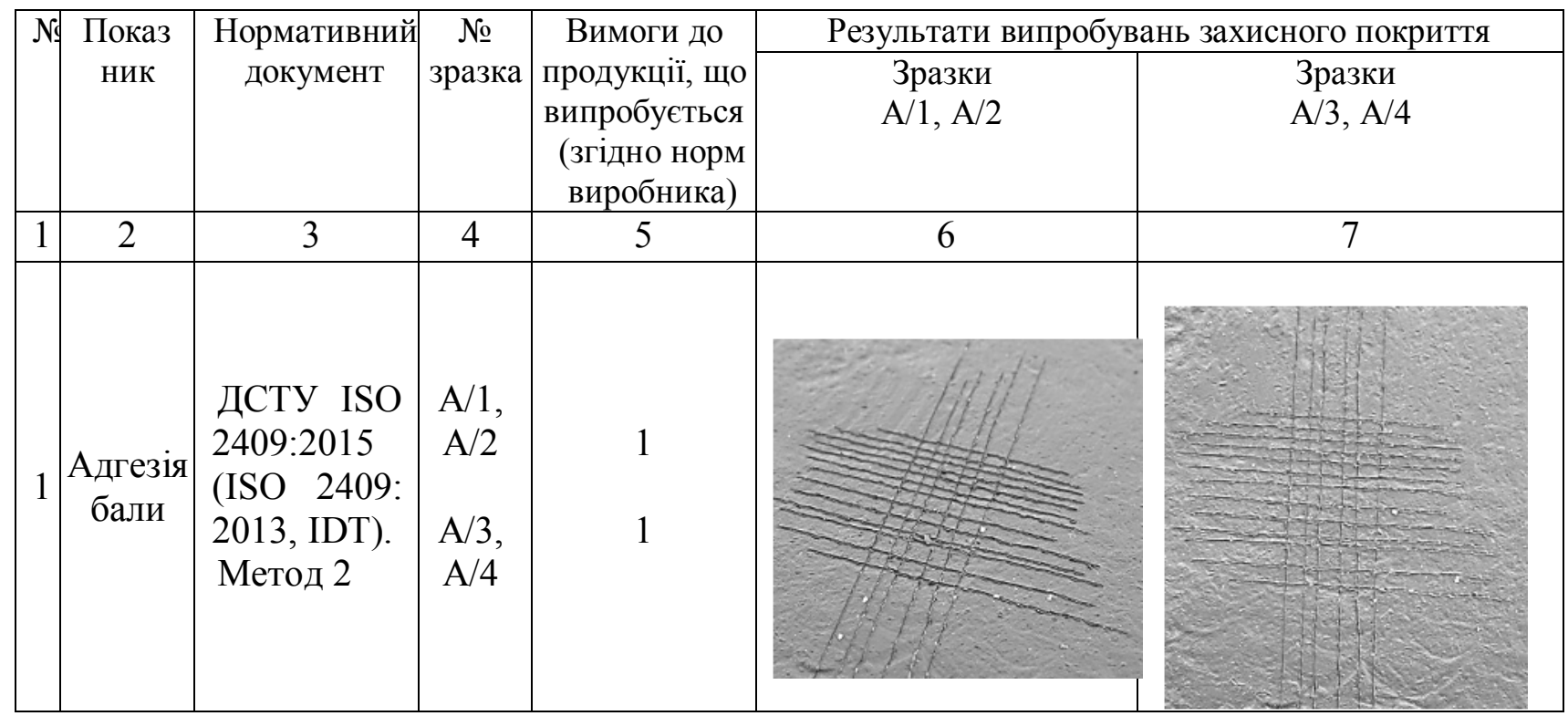

Таблиця 2 - Данні випробування елементів гранчастих конструкцій башти

\begin{tabular}{|c|c|c|c|c|c|c|}
\hline \multirow{2}{*}{$\begin{array}{l}\text { Марка } \\
\text { зразка }\end{array}$} & \multirow{2}{*}{$\begin{array}{c}\text { Вид } \\
\text { покриття }\end{array}$} & \multirow{2}{*}{$\begin{array}{l}\text { Адгезія } \\
\mathrm{R}, \mathrm{M \Pi а} \\
\left(\kappa г \mathrm{c} / \mathrm{Mm}^{2}\right)\end{array}$} & \multirow{2}{*}{$\begin{array}{l}\text { Площа } \\
\text { відриву } \\
\text { А, см }{ }^{2}\end{array}$} & \multirow{2}{*}{$\begin{array}{c}\text { Місце } \\
\text { розташування } \\
\text { ділянки } \\
\text { (край, середина) }\end{array}$} & \multicolumn{2}{|c|}{$\begin{array}{c}\text { Величина максимальних навантажень } \\
\text { при випробуваннях } \\
\text { Н (кгс) } \\
\end{array}$} \\
\hline & & & & & $\begin{array}{c}\text { при окремих } \\
\text { випробуваннях }\end{array}$ & середня по групі \\
\hline 1 & 2 & 3 & 4 & 5 & 6 & 7 \\
\hline П1 & Емаль & 0,8 & 25 & середина & $0,76 \ldots 0.81$ & 0,80 \\
\hline
\end{tabular}


Сучасні будівельні конструкиії з металу та деревини, 2020. - Вип. № 24

\begin{tabular}{|c|c|c|c|c|c|c|}
\hline П2 & Грунт & 0,7 & 25 & край & $0,65 \ldots 0.78$ & 0,78 \\
\hline П3 & Емаль & 0,6 & 25 & середина & $0,68 \ldots 0.72$ & 0,71 \\
\hline
\end{tabular}

Примітка: Адгезія емалі, міцністю зчеплення від 0,5 до 1,0 Н/мм² прийнята згідно 3

нормами ГОСТ 15140-78 та ЕN 12004 і класифікується як задовільна (1-2 бали).

Висновки. Розроблена стратегія заходів оцінки i відновлення довготривалого вторинного захисту від корозії металоконструкцій в умовах виробництва хімічного підприємства при впливі факторів середовища клімату. Заходи включають процесний підхід до управління ресурсами шляхом побудови системи обліку і функціонального контролю, аналізу ризиків та регулювання технологічної безпеки виробничих фондів підприємств 3 урахуванням рівня корозійної небезпеки. Реалізація підходу до управління технологічної безпекою на об'єктному рівні спрямована на вдосконалення СПЗК, продовження ресурсу 3 урахуванням показників живучості та обгрунтування заходів ПЗН. Однією з умов реалізації програми діагностики технічного стану будівель i споруд, a також їх окремих конструктивних елементів $є$ організація їх системного обстеження, лабораторного та натурного випробування матеріалів, визначення характеристик міцності, параметрів жорсткості і стійкості як окремих конструкцій так і споруд в цілому з урахуванням показників корозійної небезпеки.

Розроблений підхід визначає послідовність заходів продовження залишкового ресурсу 3 використанням імовірнісно-фізичного методу аналізу надійності, що включає кількісну оцінку показників надійності на основі результатів експертного діагностування і результати фізико-хімічного та математичного моделювання руйнування систем вторинного захисту від корозії при випробуваннях у польових умовах. Визначення залишкового ресурсу та прийняття рішення про подальшу експлуатацію об'єкта здійснюється відповідно до встановлених закономірностям зміни параметрів, отриманими при аналізі механізмів розвитку пошкоджень i за результатами визначення функціональних показників систем вторинного захисту конструкцій від корозії.

\section{Література}

1. Шимановський О.В. Концептуальні основи системи технічного регулювання надійності й безпечності будівельних конструкцій / Шимановський О.В., Корольов В.П. // Промислове будівництво та інженерні споруди, №1, -2008, с. 4-9.

2. Проблеми ресурсу і безпеки експлуатації конструкцій, споруд та машин / Цільова комплексна програма НАН України. Зб. наук. ст. за результатами, отриманими в $2007-2009$ pp. Наук. керівник - академік Б.С. Патон. - К.: IЕЗ ім. С. О. Патона НАН України, - 2009. $709 \mathrm{c}$.

3. Гибаленко А.Н. Мониторинг остаточного ресурса металлоконструкций в коррозионных средах / А.Н. Гибаленко // Зб. наук. пр. Серія: галузеве машинобудування, буд-во. - Полтава: ПолтНТУ, 2015. - Вип. 3 (45). - С. 110- 116.

4. ISO 9223:2012 Corrosion of metals and alloys - Corrosivity of atmospheres Classification, determination and estimation Number of pages: 15.

5. Королёв В.П., Филатов Ю.В., Селютин Ю.В. Развитие корпоративной системы менеджмента: технологическая безопасность производственных объектов / Королёв В.П., Филатов Ю.В., Селютин Ю.В. Зб. наук. праць Укрінсталькон ім. В.М. Шимановського // Під заг. ред. засл. діяча науки і тех-ки України, д.т.н., проф. О.В. Шимановського. Вип.14. - К.: Вид-во «Сталь», -2014, с. $136-149$. 
6. Gibalenko A. Design requirements to structural steel durability based on level of industrial facility corrosion hazard / A Gibalenko, V Korolov, J Filatov // AKTUALNE PROBLEMY KONSTRUKCJI METALOWYCH. 2014, Gdańsk Poland. - P. 98-102.

7. Guedes Soares, C., Garbatov, Y., Zayed, A. and Wang, G. (2009) Influence of Environmental Factors on Corrosion of Ship Structures in Marine Atmosphere. Corrosion Science, 51, 2014-2026.

8. Nadim, Mahmudul and Arifur, Numerical Analysis of Pit Shape Effect On Corrosion Diminution And Struc-tural Integrity Parameters Of Ship, B.Sc. Thesis, MIST, Dhaka, Bangladesh, 2015.

9. Estimation of steel structure corrosion risk level / V. P. Korolov, Y. Vysotsky, O. M. Gibalenko, P.V. Korolov // Eurocorr-2010. The European Corrosion Congress (13.09-17.09.2010) / From the Earth`s Depths to Space Heights. - Moscow, 2010. - Book of Abstracts. -534 p.

10. Sumi Y, Strength and Deformability of Corroded Steel Plates Estimated by Replicated Specimens (Journal of Ship Production, 24(3), 2008), pp. 161-167.

11. Korolov V. Design criteria of reliability and safety in the design of corrosion protection of structural steel / V. Korolov, Y. Vysotskyy, Y. Filatov / EUROCORR-2014. The European Corrosion Congress «Improving materials durability: from cultural heritage to industrial applications». - Pisa, Book of Abstracts. - 2014. - 88 p.

12. Zienkiewicz O.C. The Finite Element Method for Solid and Structural Mechanics Sixth edition / O.C. Zienkiewicz, R.L. Taylor // Elsevier Butterworth-Heinemann Linacre House, Jordan Hill, Oxford OX2 8DP 30 Corporate Drive, Burlington, MA 01803. - 2005. - 648 p.

13. American Rust Standard Guide. New York: American Institute for Steel Classification. American rust standard guide. New York: American Institute for Steel Classification, c. 1968 (OCoLC)746104088, Media Type: Book. Publisher: American Institute for Steel Classification. Publish Date: 31/12/2002. Code ID: 24016. Pages: 12

14. ДБН В.2.6-198:2014 Сталеві конструкції. Норми проектування / Мінрегіон України. - Київ, 2014. - 199 с.

15. ДСТУ Б В.2.6-193:2013 Захист металевих конструкцій від корозії. Вимоги до проектування. - Мінрегіон України. - 74 с.

\section{References}

[1] Shimanovskyj O.V. (2008). Conceptual bases of system of technical regulation of reliability and safety of building structures. Industrial construction and engineering. №1, 4-9.

[2] Paton B.E. (2009). Resource and safety issues for the operation of structures, structures and machines / Target comprehensive program of NAS of Ukraine. Coll. Sciences. Art. according to the results obtained in 2007 - 2009. NAN Ukraine. 709.

[3] Gibalenko A.N. Monitoring of residual life of steel structures in corrosive media. Coll. Sciences. ave. Series: industrial engineering, building. Poltava: PoltNTU. 3 (45). 110- 116.

[4] Corrosion of metals and alloys. Corrosivity of atmospheres - Classification, determination and estimation. 15. ISO 9223:2012.

[5] .Korolev V.P., Filatov U.V., Selutin U.V. (2014). Development of corporate management system: technological safety of production facilities. Coll. Sciences. works of Ukrinstalkon them. V.M. Shimanovsky. Publishing house Stal. 14. 136-149.

[6. Gibalenko A. Design requirements to structural steel durability based on level of industrial facility corrosion hazard / A Gibalenko, V Korolov, J Filatov // AKTUALNE PROBLEMY KONSTRUKCJI METALOWYCH. 2014, Gdańsk Poland. - P. 98-102.

[7] Guedes Soares, C., Garbatov, Y., Zayed, A. and Wang, G. (2009). Influence of Environmental Factors on Corrosion of Ship Structures in Marine Atmosphere. Corrosion Science. 51, pp 2014-2026. 
[8] Nadim, Mahmudul Arifur (2015). Numerical Analysis of Pit Shape Effect On Corrosion Diminution And Structural Integrity Parameters Of Ship (Bachelor thesis).

[9] Korolov V.P., Vysotsky Y.V., Gibalenko O. M. (2010) KorEstimation of steel structure corrosion risk level. The European Corrosion Congress "From the Earth's Depths to Space Heights". 534 p.

[10] Sumi Y. (2008). Strength and Deformability of Corroded Steel Plates Estimated by Replicated Specimens. Journal of Ship Production. 24(3). pp 161-167.

[11] Korolov V. (2014). Design criteria of reliability and safety in the design of corrosion protection of structural steel. The European Corrosion Congress «Improving materials durability from cultural heritage to industrial applications». $88 \mathrm{p}$.

[12] Zienkiewicz O.C. (2005). The Finite Element Method for Solid and Structural Mechanics Sixth. Oxford,. 648 p.

[13] New York: American Institute for Steel Classification. (2002). American Rust Standard Guide. 1. 12 .

[14] Ministry of Regional Development of Ukraine. (2014). Steel structures. Norms of designing. 199 p., (National Standard of Ukraine) DSTU B.2.6-198:2014.

[15] Ministry of Regional Development of Ukraine. (2014). Corrosion protection of metal structures. Design requirements. 74 p., (National Standard of Ukraine) DSTU B.2.6-193:2013.

\title{
ТЕХНОЛОГИЧНОСТЬ РАБОТ ОБЕСПЕЧЕНИЯ ВТОРИЧНОЙ ЗАЩИТЫ МЕТАЛЛОКОНСТРУКЦИЙ ОТ КОРРОЗИИ В УСЛОВИЯХ ХИМИЧЕСКИ АКТИВНЫХ СРЕД
}

\author{
Гибаленко А.Н., д.Т.Н., профессор \\ grin196102@gmail.com, ORCID:0000-0003-2979-5225 \\ Гибаленко В.А., к.т.н., доцент \\ vita.ktn@gmail.com, ORCID: 0000-0001-5590-6641 \\ Бочарова О.А., ст. преподаватель \\ kaleriabocharova@gmail.com, ORCID:0000-0003-3993-5842 \\ ГВУЗ «Приазовский государственный технический университет»
}

В работе изложены результаты исследований, направленных на определение признаков коррозионного разрушения, условий мониторинга и диагностики технического состояния металлоконструкций по уровню коррозионной опасности. Рассмотрено эксплуатационное состояние конструкций несущей башни дымовой трубы, эксплуатация которой происходит в средах химического производства.

Использованы принципы процессного подхода для реализации задач управления сроком службы в коррозионных агрессивных средах. В результате исследований определены меры обеспечения долговечности в соответствии с уровнем коррозионной опасности строительного объекта, выявлены критические показатели средств вторичной защиты металлоконструкций в условиях режима коррозионных воздействий в пределах интервальных оценок значений рассматриваемых показателей.

Определение остаточного ресурса и принятие решений о дальнейшей эксплуатации объекта осуществляется согласно установленным закономерностям изменения параметров, полученных при анализе механизмов развития повреждений и по результатам определения функциональных показателей качества.

Использование разработанного похода при назначении меры вторичной защиты от коррозии по критерию коррозионной опасности позволяет обеспечить требования надежности и соответствие нормативным положениям качества металлоконструкций на основе решение задач по управлению технологической безопасностью в течение 
установленного срока службы. В перечень решаемых задач входит: выявлять отклонения от требований действующих нормативных документов по защите от коррозии; оценивать соответствие показателей качества, конструктивной приспособленности и технологической рациональности средств и методов противокоррозионной защиты заданному уровню коррозионной опасности; определять требования к выбору материалов и систем защитных покрытий металлоконструкций согласно классификационным признакам нормативных требований; разрабатывать предложения по использованию средств и методов противокоррозионной защиты на основании экспертизы новых материалов и технологий по условиям оценки соответствия требованиям надежности и эффективности.

Ключевые слова: дефекты, коррозионная опасность, технологичность, несущая башня, противокоррозионное покрытия, процессный подход, надежность.

\title{
TECHNOLOGICAL WORK OF PROVIDING SECONDARY PROTECTION OF METAL STRUCTURES AGAINST CORROSION IN CONDITIONS OF CHEMICAL ACTIVE ENVIRONMENTS
}

\author{
Gibalenko O. M., D.Sc., Professor, \\ grin196102@gmail.com, ORCID:0000-0003-2979-5225 \\ Gibalenko V.A., Ph.D., Associate Professor, \\ vita.ktn@gmail.com, ORCID:0000-0001-5590-6641 \\ Bocharova O.A., art. Teacher \\ kaleriabocharova@gmail.com, ORCID:0000-0003-3993-5842 \\ State Higher Education Institution "Pryazovskyi State Technical University"
}

\begin{abstract}
Annotation. The paper presents the results of a study aimed at identifying signs corrosion damage, conditions for monitoring and diagnosing the technical condition of metal structures according to the level corrosion hazard. The paper presents the results of a study aimed at identifying signs corrosion damage, conditions for monitoring and diagnosing the technical condition of metal structures according to the level corrosion hazard. Current state of constructions supporting tower the pipe, the operation which occurs in environments of chemical production

Principles process approach are used to implement the tasks of managing e service life in corrosive aggressive environments. The study identified measures to ensure durability in accordance with the level of corrosion hazard a building object, identified critical indicators secondary protection of metal structures under the conditions corrosion impacts, within the interval estimates of the values considered indicators. The determination residual resource and the adoption decisions on the further operation facility is carried out in accordance with the established patterns changing the parameters obtained by analyzing mechanisms damage development and by determining the functional quality indicators.

Assigned measures of secondary corrosion protection by the criterion corrosion hazard allow us to ensure reliability requirements and compliance with the regulatory provisions of the quality of metal structures based on the solution tasks $r$ managing technological safety for a specified period.

The list of tasks to be solved includes: identifying deviations from the requirements of current regulatory documents on corrosion protection; assess the conformity of quality indicators, constructive fitness and technological rationality means methods of corrosion protection to a given level corrosion hazard; determine the requirements for the selection of materials and protective systems for metal structures according to the classification features regulatory requirements; to develop proposals for the use of tools and methods corrosion protection based on the examination of new materials and technologies for the assessment compliance with the requirements reliability and efficiency.
\end{abstract}

Key words: defects, corrosion hazard, manufacturability, carrier tower, anticorrosion coatings, process approach, reliability. 


\title{
ДОСВІД ПРОЕКТУВАННЯ ТА БУДІВНИЦТВА НАВІСУ НАД БУДІВЛЕЮ
}

\author{
Голоднов О.I., д.т.н., проф., \\ ТОВ «Укрінсталькон ім. В.М. Шимановського», м. Київ, Україна, \\ golodnow@ukr.net; ORCID: 0000-0002-9722-9164;
}

Антошина T.В., к.т.н., ТОВ «ГЛОБАЛ ПРОДЖЕКТ», Україна, tvantos@ukr.net; ORCID: 0000-0002-6601-6078.

Анотація. Проектування, розрахунки, виготовлення і монтаж несучих сталевих i огороджувальних конструкцій навісу над існуючою будівлею виконано у зв'язку 3 необхідністю захисту розміщеного на покритті технологічного обладнання і автомобілів від атмосферних опадів та інших кліматичних чинників.

Було проведено комп'ютерне моделювання, розрахунки конструкцій навісу відповідно до вимог чинних нормативних документів і зроблено висновок про можливість будівництва навісу над будівлею. Конструкції навісу було виготовлено та змонтовано.

Ключові слова: експлуатована будівля, несучі конструкції, технічний стан, навіс, сталеві конструкції, проектування, виготовлення, монтаж.

Вступ. Постановка проблеми. Надійність будівельних конструкцій повинна бути забезпечена відповідно до вимог чинних нормативних документів $[1,2,3]$.

Основні вимоги щодо проектування сталевих конструкцій викладено в розділі 5 ДБН В.2.6-198:2014 [1]. При проектуванні необхідно:

- забезпечувати надійність конструкцій за рахунок виконання вимог до вибору матеріалів, конструювання та розрахунків;

- приймати конструктивні рішення, що забезпечують міцність, жорсткість, стійкість і просторову незмінюваність будівель та споруд в цілому та їхніх окремих елементів під час транспортування, монтажу та експлуатації, при цьому передбачаючи в'язі залежно від основних параметрів будівлі та режиму іï експлуатації (конструктивної схеми, прольотів, типів кранів та режимів їх роботи, температурних впливів тощо);

- передбачувати заходи щодо забезпечення довговічності конструкцій та захисту їх від корозії, впливу вогню і тепла, зносу та стирання;

- враховувати вимоги чинних нормативних документів стосовно забезпечення міцності та стійкості несучих конструкцій в умовах пожежі;

- передбачувати технологічність виготовлення та монтажу конструкцій;

- забезпечувати складальність конструкцій розрахунком точності геометричних параметрів зі встановленням необхідності контрольного чи загального складання або використанням регулювальних пристроїв;

- враховувати відхилення від проектних розмірів і геометричної форми елементів конструкцій, які допускаються під час виготовлення та зведення;

- встановлювати методи та обсяги контролю під час виготовлення та зведення конструкцій, а також у процесі їхньої експлуатації, включаючи, за необхідності, виконання випробувань окремих елементів, вузлів, з'єднань і конструкцій у цілому, а також, за необхідності, встановлення контрольно-сигнальних систем чи інших засобів моніторингу;

- передбачати можливість огляду, обстеження та діагностики, а також проведення профілактичних і ремонтних робіт. За необхідності передбачати для цього ходові сходи та площадки, спеціальні пристосування (столики, провушини, фіксатори тощо) для забезпечення можливості кріплення постійних i тимчасових пристосувань, а також пристосувань для встановлення засобів діагностики технічного стану конструкцій у процесі експлуатації. 
Кліматичні дані району будівництва слід приймати згідно з вимогами розділу 11 ДБН В.1.2-2:2006 [2]. Розрахункові технологічні температури необхідно встановлювати завданням на розроблення будівельної частини проекту.

Згідно з розділом 11 ДБН В.1.2-2:2006 [2], температурні кліматичні впливи є змінними впливами, для яких встановлено три розрахункові значення:

- граничне розрахункове значення;

- експлуатаційне розрахункове значення;

- квазіпостійне розрахункове значення.

Визначення параметрів температурного впливу необхідно виконувати у відповідності до вимог розділу 11 ДБН В.1.2-2:2006 [2].

Аналіз останніх джерел досліджень і публікацій. Разом з новим будівництвом все частіше виникає необхідність в проведенні робіт по відновленню експлуатаційної придатності будівельних конструкцій будівель та споруд, а також добудови у зв'язку із зміною функціонального призначення або необхідністю покращання експлуатаційних показників будівлі. При цьому необхідно вирішувати питання, пов'язані 3 визначенням напружено-деформованого стану (НДС) i виконанням робіт із продовження терміну експлуатації споруд.

Вказані роботи необхідно вирішувати в комплексі, тобто прогнозу можливого продовження терміну експлуатації конструкцій будівель та споруд повинні передувати роботи, пов'язані з оцінкою їхнього технічного стану. Ці роботи виконуються відповідно до вимог чинних нормативних документів $[3,4]$.

Оцінка технічного стану виконується на підставі результатів раніше виконаних і поточних обстежень, перевірочних розрахунків тощо. Перевірочні розрахунки виконуються, як правило, із застосуванням спрощених розрахункових схем без урахування фактичного стану конструкцій і прогнозу деградації властивостей матеріалів. Такий підхід не дозволяє моделювати НДС споруд в динаміці розвитку процесів деградації та не дає можливості прийняти правильне рішення про склад заходів, що забезпечують подальшу надійну та безпечну експлуатацію конструкцій [5].

Через все вищевикладене передбачається, що йдеться про розрахунок i застосування підсилення (добудови) будівлі за цілком певною схемою із заздалегідь заданими параметрами і при відомих впливах на неї. Підтвердженням правомірності прийнятої схеми підсилення або добудови будівлі мають бути результати моделювання конструкцій будівлі з використанням сучасних програмних комплексів методу скінчених елементів (ПК МСЕ) для розрахунку конструкцій і постійного моніторингу будівель у відповідності з вимогами ДСТУ-Н Б В.1.2-17:2016 [6].

В статті наведено приклад розрахунку, проектування, виготовлення i монтажу конструкцій навісу над експлуатованим покриттям існуючої будівлі у зв'язку з необхідністю захисту розміщеного на покритті технологічного обладнання і автомобілів від атмосферних опадів та інших кліматичних чинників.

Формулювання мети та методів дослідження. Мета цієї роботи полягає в розробці взаємозв'язаних заходів щодо визначення параметрів технічного стану експлуатованих будівельних конструкцій, будівель та споруд в цілому, обгрунтування можливості добудови існуючих будівель у зв'язку зі зміною функціонального призначення або необхідністю покращання експлуатаційних показників будівлі.

Оцінка технічного стану конструкцій існуючих будівель за умови реконструкції виконується в такій послідовності $[3,4,5]$ :

- аналіз технічної документації;

- візуальне обстеження конструкцій;

- інструментальне обстеження конструкцій;

- аналіз результатів візуального й інструментального обстеження;

- виконання перевірочних розрахунків (за необхідності) з урахуванням можливості розвитку особливих впливів; 
- оцінка технічного стану на основі проведених досліджень;

- висновок про можливість подальшої експлуатації в існуючому стані або реконструкції з можливістю добудови (за необхідності);

- проектування, виготовлення, транспортування і монтаж конструкцій підсилення (добудови).

Основний матеріал і результати. Для оцінки технічного стану конструкцій використовуються [5]:

- критерій відповідності конструкції (споруди) робочій документації (розміри, конструктивні особливості, засоби захисту від агресивних впливів оточуючого середовища, вогнестійкості тощо);

- критерій відповідності конструкції (споруди) визначальним параметрам технічного стану та вогнестійкості (наявність або відсутність неприпустимих дефектів, відповідність застосованих матеріалів і засобів вогнезахисту вимогам проекту та чинних нормативних документів України тощо) і задоволення вимогам розрахунку за граничними станами.

Особливо важливим $є$ об'єктивність і оперативність моніторингу, можливість оцінювати за його допомогою поточний технічний стан об'єктів і прогнозувати їхню довговічність, виключати при цьому можливість переходу об'єктів в аварійний стан.

Важливими в практичному відношенні можна вважати економічність моніторингу, потрібний рівень професіоналізму обслуговуючого персоналу, доступність отримання інформації користувачами тощо.

Удосконалення методики розрахунку із залученням сучасних програмних комплексів на основі методу скінчених елементів (ПК МСЕ) з метою визначення залишкової несучої здатності сталевих конструкцій, що зазнали на протязі певного часу дію різних чинників впливу та обгрунтування можливості реконструкції з добудовою, вимагає використання такої моделі деформування матеріалів, яка б включала всі етапи його роботи від початку навантаження до повного руйнування.

Оцінка технічного стану конструкцій (споруди) проводиться шляхом зіставлення контрольованих параметрів, які визначено в ході проведення візуального й інструментального обстежень, 3 відповідними проектними параметрами, а також за результатами перевірних розрахунків.

Нижче наведено приклад використання розробленої методики в частині обстеження конструкцій існуючої будівлі, проектуванні, розробці комп’ютерної моделі, розрахунках, виготовленні та монтажу конструкцій навісу над існуючою будівлею у зв'язку з необхідністю захисту розміщеного на покритті технологічного обладнання і автомобілів від атмосферних опадів та інших кліматичних чинників.

Існуюча будівля 3 експлуатованою покрівлею являє собою двоповерхову багатопролітну споруду зі змішаним каркасом складної форми в плані (рис. 1).

Конструкції будівлі виконано в монолітному залізобетоні. На період ухвалення рішення про можливість будівництва навісу несучі конструкції будівлі були виготовлені, плоска покрівля виконана, а у внутрішніх приміщеннях виконувалось оздоблення. Перед проектуванням навісу було виконано обстеження будівельних конструкцій і обмірні роботи.

Перед виконанням робіт із моделювання, розрахунку і проектування конструкцій був виконаний аналіз наявної проектної документації існуючої будівлі. Було проведено комп'ютерне моделювання, розрахунки конструкцій навісу (рис. 2) відповідно до вимог чинних нормативних документів і зроблено висновок про можливість будівництва навісу.

Навіс запроектовано як просторову споруду зі сталевим каркасом. Вертикальними несучими елементами навісу служать сталеві колони з прокатних труб квадратного перерізу. Колони встановлюються по контуру і по осях В'..4 та В'.4 (рис. 1).

Колони жорстко закріплюються до елементів покриття і до залізобетонних стін парапету по висоті. На колони по осях В'’.4 та В'.4 спираються підкроквяні ферми. На підкроквяні ферми, колони по осях В".4 і В'.4 і колони по контуру спираються кроквяні 
ферми. По верхніх поясах ферм встановлюються прогони. Між фермами і колонами ставляться горизонтальні та вертикальні в'язі та розпірки.

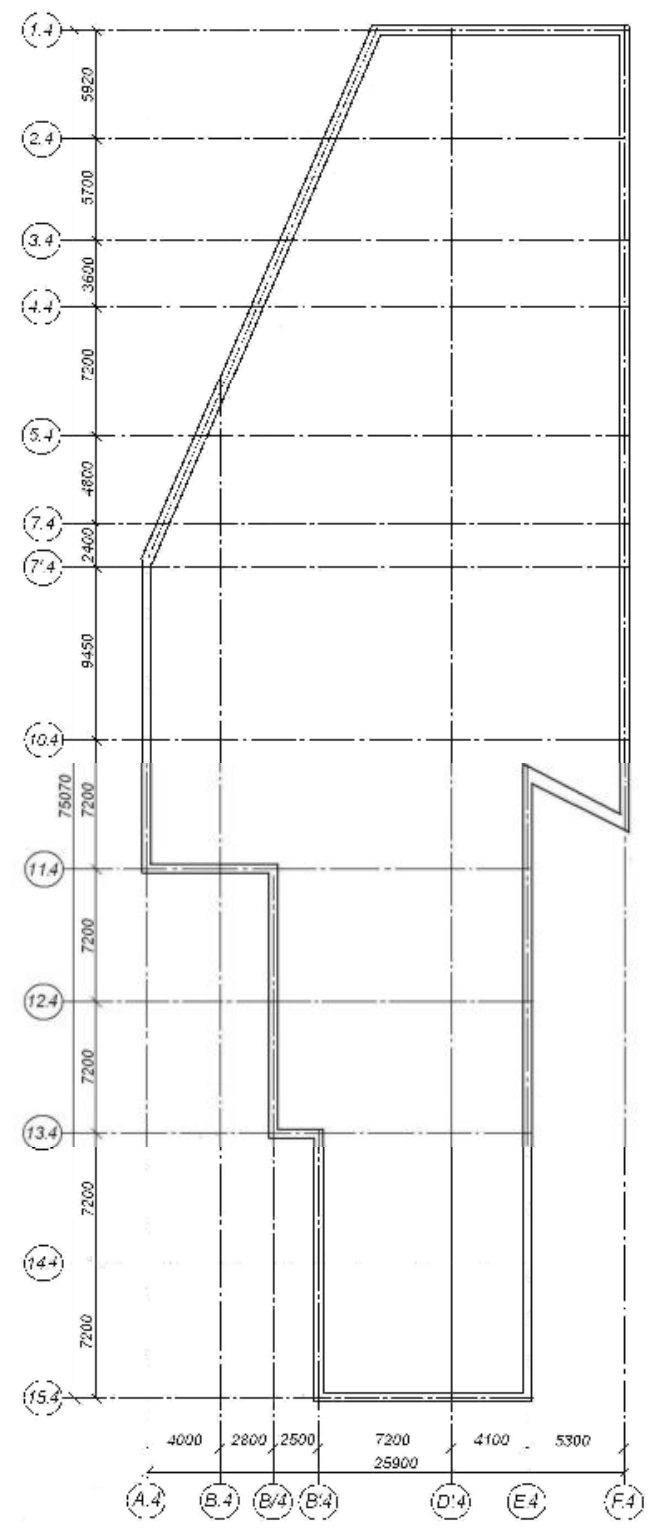

Рис. 1. План покриття будівлі

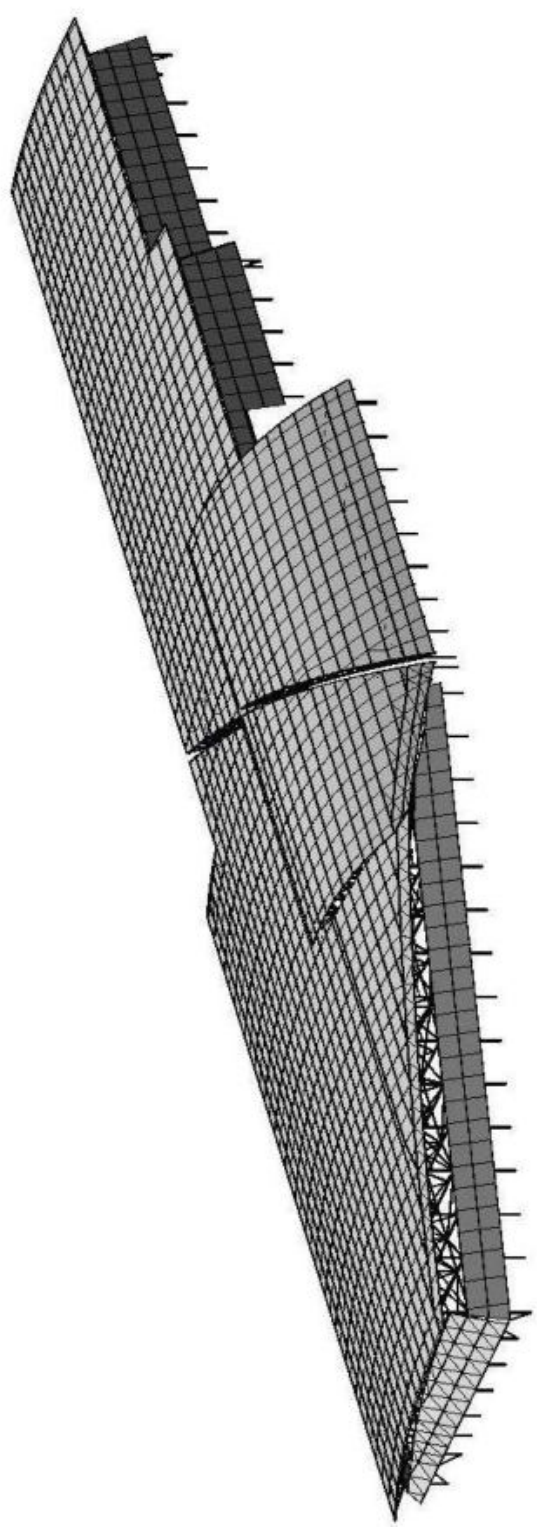

Рис. 2. Повна комп'ютерна модель навісу

Відповідно до вимог нормативних документів окремі елементи конструкцій навісу було об’єднано в просторовий каркас із створенням жорсткого конструктиву. Для збільшення жорсткості конструктиву в покритті з використанням сталевого профільованого настилу передбачено систему в'язів в площині верхніх поясів ферм, в якій роль розпірок виконали прогони.

На підставі виконаних розрахунків було визначено зусилля в елементах комп'ютерної моделі і встановлено необхідні перерізи елементів колон, ферм, прогонів тощо. Всього було запроектовано близько 55 типорозмірів ферм, більше 100 типорозмірів колон, а також безліч інших елементів (прогонів, в'язів, розпірок, елементів покрівлі тощо).

Обпирання конструкцій навісу виконано на конструкції покриття існуючої будівлі, які виконано в монолітному залізобетоні. Навіс $\epsilon$ тимчасовою спорудою із скатною покрівлею для будівлі з експлуатованим покриттям. Маса конструкцій навісу склала приблизно 38 т $(26$ кг/м²), що значно менше маси конструкцій будівлі та корисного навантаження, величина яких перевищує $1000 \mathrm{\kappa} / \mathrm{M}^{2}$. 
Після цього конструкції були виготовлені, транспортовані та змонтовані (рис. 3, 4).

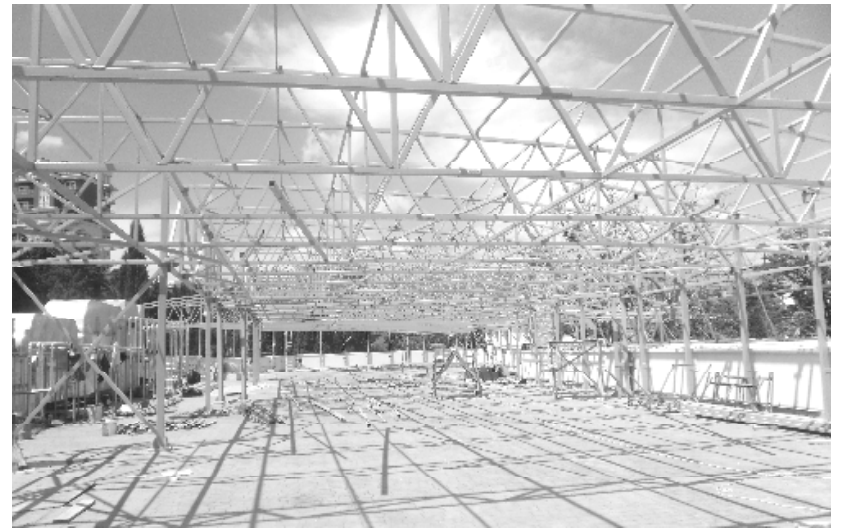

Рис. 3. Загальний вигляд сталевих конструкцій навісу під час монтажу

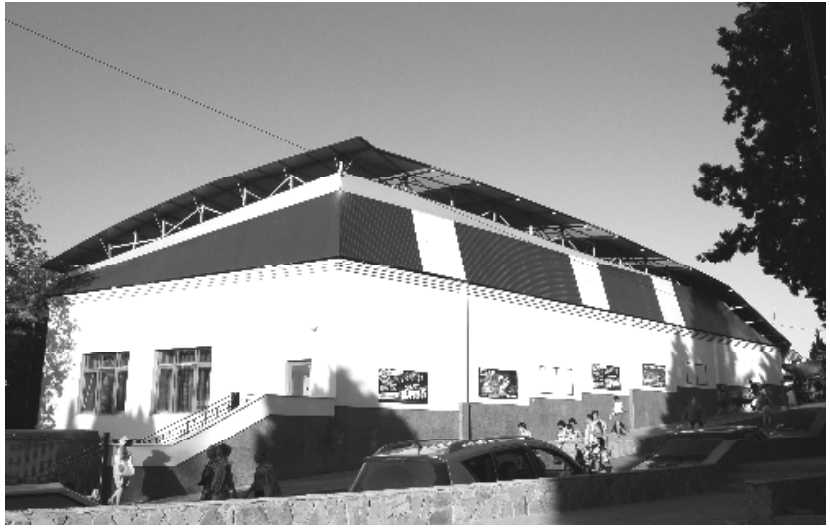

Рис. 4. Загальний вигляд змонтованих конструкцій навісу

3 початку роботи (виїзд на місце, ознайомлення з об'єктом, обмірні роботи) до здачі об'єкту в експлуатацію пройшло трохи більше за 100 днів.

Висновки. В ході проведених досліджень зроблено наступні висновки.

1. Удосконалено методику оцінювання технічного стану конструкцій на етапі експлуатації будівель та споруд. Розроблено методи розрахунку конструкцій, оцінки технічного стану та можливості його регулювання для подальшої експлуатації конструкцій будівель та споруд, а також при реконструкції з можливою добудовою.

2. Навіс являє собою одноповерхову просторову раму, що складається з жорстко сполучених із залізобетонними конструкціями покриття колон і ферм, які спираються на оголовки колон. З'єднання ферм з колонами жорстке i шарнірне. Система в'язів по колонах $\mathrm{i}$ покритті забезпечує просторову жорсткість споруди. Маса конструкцій навісу склала приблизно 38 т.

3. На підставі виконаних розрахунків з використанням ПК МСЕ були визначені зусилля в елементах комп'ютерної моделі, встановлені необхідні перерізи елементів колон, ферм, прогонів тощо. Конструкції було виготовлено, транспортовано та змонтовано. 3 початку робіт (виїзд на місце, ознайомлення 3 об'єктом, обмірні роботи) до здачі об'єкту в експлуатацію пройшло трохи більше 100 днів.

\section{Література}

1. ДБН В.2.6-198:2014. Сталеві конструкції. Норми проектування. (2015). - Київ: Мінрегіонбуд України, 199.

2. ДБН В.1.2-2:2006. Навантаження і впливи. Норми проектування. (2007). - Київ: Мінбуд України, 60.

3. ДСТУ-Н Б В.1.2-18:2016. Настанова щодо обстеження будівель і споруд для визначення та оцінки їх технічного стану. (2017). - К.: ДП «УкрНДНЦ», 45.

4. ДСТУ Б В.2.6-210:2016. Оцінка технічного стану сталевих будівельних конструкцій, що експлуатуються. (2017). - К. : Мінрегіон України, 53.

5. Голоднов, О., Антошина, Т., Отрош, Ю. (2017). Про необхідність розрахунку будівель зі сталевим каркасом на температурні впливи. Збірник наукових праць Українського інституту сталевих конструкцій імені В. М. Шимановського, 20, 65-84.

6. ДСТУ-Н Б В.1.2-17:2016. Настанова щодо науково-технічного моніторингу будівель і споруд. (2017). - Київ: Мінрегіон України, 45. 


\title{
References
}

[1] DBN V. 2.6-198:2014. Stalevi konstruktsiyi. Normi proektuvannja. (2015). - Kyiv: Minregion Ukrayini, 199.

[2] DBN V.1.2-2:2006. Navantagennja i vplivi. Normi proektuvannja. (2007). - Kyiv: Minbud Ukrayini, 60.

[3] DSTU-N B V.1.2-18:2016. Nastanova shchodo obstezhennya budivel i sporud dlya vyznachennya ta oczinky yikh tekhnichnoho stanu. (2017). Kyiv: DP «UkrNDNTs», 45.

[4] DSTU B V.2.6-210:2016. Oczinka tekhnichnogo stanu stalevikh budivelnikh konstrukczij, shho ekspluatuyutsya. (2017). - Kyiv: Minregion Ukrayini, 53.

[5] Holodnov, O., Antoshina, T., Otrosh, Yu. (2017). Pro neobkhidnist rozrakhunku budivel zi stalevym karkasom na temperaturni vplyvy. Zbirnyk naukovykh prats Ukrayinskoho instytutu stalevykh konstruktsiy imeni V. M. Shymanovskoho, 20, 65-84.

[6] DSTU-N B V.1.2-17:2016. Nastanova shchodo naukovo-tekhnitchnogo monitoringu budivel i sporud. (2017). - Kyiv: Minregion Ukrayini, 45.

\section{ОПЫТ ПРОЕКТИРОВАНИЯ И СТРОИТЕЛЬСТВА НАВЕСА НАД ЗДАНИЕМ}

Голоднов А.И., д.т.н., проф.,

ООО «Укринсталькон им. В.М. Шимановского », г. Киев, Украина, golodnow@ukr.net; ORCID: 0000-0002-9722-9164;

Антошина T.В., к.т.н., ООО «ГЛОБАЛ ПРОДЖЕКТ》, Украина, tvantos@ukr.net; ORCID: 0000-0002-6601-6078.

\begin{abstract}
Аннотация. Обобщенно современное состояние вопроса, поставлены задачи исследований, разработана методика оценки технического состояния эксплуатируемых конструкций зданий и сооружений. Анализ существующих методик позволил установить, что отсутствуют доведенные до практического использования методы расчета строительных конструкций, оценки их технического состояния и обоснования возможности последующей надежной эксплуатации после различных воздействий, а также при условии реконструкции с достройкой.
\end{abstract}

Предложена процедура оценки технического состояния и несущей способности эксплуатируемых конструкций при реконструкции.

Разработана методика получения определяющих параметров технического состояния конструкций. Предусмотрено, что конструкции и элементы на протяжении всего жизненного цикла в результате старения, деградации и других воздействий могут последовательно находиться в каждом из четырех технических состояний.

Приведены результаты выполненного обследования и оценки технического состояния строительных конструкций существующего здания, на покрытии которого необходимо было смонтировать навес.

Проектирование, расчеты, изготовление и монтаж несущих стальных и ограждающих конструкций навеса над покрытием существующего здания были выполнены в связи с необходимостью защиты размещенного на покрытии технологического оборудования и автомобилей от атмосферных осадков и других климатических факторов.

Навес представляет собой одноэтажную пространственную раму, состоящую из жестко соединенных с железобетонными конструкциями покрытия колонн и ферм, опирающихся на оголовки колонн. Соединение ферм с колоннами жесткое и шарнирное. Система связей по колоннам и покрытию обеспечивает пространственную жесткость сооружения.

На основании выполненных расчетов с использованием ПК МКЭ были определены усилия в элементах компьютерной модели, установлены необходимые сечения элементов колонн, ферм, прогонов, связей. Были выполнены также изготовление, транспортирование и 
монтаж конструкций. С начала работ до сдачи объекта в эксплуатацию прошло немногим более 100 дней.

Ключевые слова: эксплуатируемое здание, несущие конструкции, техническое состояние, навес, стальные конструкции, проектирование, изготовление, монтаж.

\title{
EXPERIENCE OF DESIGNING AND CONSTRUCTION OF BALDACHINS OVER THE BUILDING
}

\author{
Holodnov O., Doctor of Technical Sciences, prof., \\ LLC “V. Shimanovsky Ukrainian Institute of Steel Construction”, Kyiv, Ukraine, \\ golodnow@ukr.net; ORCID: 0000-0002-9722-9164; \\ Antoshina T., Cand. of Technical Sciences, \\ Global Project LTD, Ukraine, \\ tvantos@ukr.net; ORCID: 0000-0002-6601-6078.
}

\begin{abstract}
The current state of the issue is generalized, research objectives are set, a methodology has been developed for assessing the technical condition of operating structures of buildings and structures. An analysis of the existing methods made it possible to establish that there are no methods for calculating building structures brought to practical use, evaluating their technical condition and justifying the possibility of subsequent reliable operation after various influences, as well as under the condition of reconstruction with completion.

A procedure is proposed for assessing the technical condition and bearing capacity of exploited structures during reconstruction.

A technique has been developed for obtaining the determining parameters of the technical state of structures. It is envisaged that structures and elements throughout the entire life cycle as a result of aging, degradation, and other influences can consistently be in each of the four technical states.

The results of the survey and assessment of the technical condition of the building structures of the existing building are presented, on the cover of which it was necessary to mount the canopy.

The design, calculations, manufacture and installation of load-bearing steel and enclosing structures of the canopy over the coating of the existing building were carried out in connection with the need to protect the technological equipment and automobiles located on the coating from atmospheric precipitation and other climatic factors.

The canopy is a one-story spatial frame, consisting of columns and trusses rigidly connected to reinforced concrete structures, based on the column heads. The connection of trusses with columns is rigid and articulated. The system of ties along the columns and the coating provides the spatial rigidity of the structure.

Based on the calculations performed using the FEM PC, the forces in the elements of the computer model were determined, the necessary sections of the elements of the columns, trusses, runs, connections were established. The manufacture, transportation and installation of structures were also performed. From the beginning of work to the commissioning of the facility a little more than 100 days passed.
\end{abstract}

Key words: operated building, load-bearing structures, technical condition, canopy, steel structures, design, manufacturing, installation. 


\title{
РОЗВИНЕНА МОДЕЛЬ РОЗРАХУНКУ СТАЛЕВИХ РОЗКРІПЛЕНИХ ЕЛЕМЕНТІВ НА СТІЙКІСТЬ ПРИ СУМІСНІЙ ДІЇ ПОПЕРЕЧНОГО ЗГИНУ ТА КРУЧЕННЯ
}

\author{
Гудзь С.А., к.т.н., доцент \\ goods.sergiy@gmail.com ORCID 0000-0002-4764-8635 \\ Національний університет «Полтавська політехніка імені Юрія Кондратюка» \\ Гасій Г.М., д.т.н., доцент \\ grigoriigm@gmail.com ORCID 0000-0002-1492-0460 \\ Сумський наиіональний аграрний університет \\ Дарієнко В.В., к.т.н., доцент \\ vvdarienko@gmail.com ORCID 0000-0001-9023-6030 \\ Центральноукраӥнський національний технічний університет
}

\begin{abstract}
Анотація. Розглянуто основні етапи розрахунку сталевих розкріплених згинаних елементів із початковими недосконалостями за деформованою схемою. Розкріплення може відбуватися за допомогою приєднаних до сталевої балки конструкцій. На основі нового підходу до аналізу внутрішніх силових факторів було поставлено за мету знайти та описати особливості експлуатації балки при сумісній дії поперечного згину та кручення. Удосконалено існуючу теоретичну модель при усуненні присутніх у ній недоліків. На прикладах проведено порівняння методик визначення несучої здатності за стійкістю гнучких елементів. Запропоновано збільшити економію матеріалу шляхом деталізації розрахунку.

Ключові слова: бімомент, викривлення, втрата стійкості, кручення, розкріплення.
\end{abstract}

Вступ. Унаслідок ексцентричного прикладення навантаження у сталевих елементах різного призначення з відкритим поперечним перерізом з'являються деформації обмеженого кручення, що призводять до відповідних додаткових напружень, названих секторіальними. Проблема врахування цих напружень тісно пов'язана 3 таким явищем як «згинальнокрутильна форма втрати стійкості», котру для балок прийнято називати «поперечнокрутильна форма втрати стійкості». В цьому контексті існує суперечність, на яку слід звернути увагу і яка полягає у невідповідності роботи розкріпленої конструкції більшості класичних теоретичних уявлень про обмежене кручення тонкостінних стрижнів. Значна кількість математичних моделей характеризує лише деякі особливості поводження конструкції у складі каркасу. У таких випадках дійсні процеси не завжди відображаються при моделюванні, яке не відповідає реальній картині напружено-деформованого стану. Ступінь використання поперечного перерізу за напруженнями, необхідний для забезпечення надійності конструкції загалом, потребує уточнення для його адекватного відображення. Внутрішні зусилля потрібно визначати за нелінійною теорією другого порядку для збільшення точності розрахунків і наближення їх до дійсних умов роботи конструкції. Вона являє собою по суті розрахунок за деформованою схемою, в якому рівняння рівноваги записуються для деформованого стану системи, враховуючи геометричну нелінійність.

Огляд останніх джерел досліджень і публікацій. Сучасні експериментальнотеоретичні дослідження напружено-деформованого стану і стійкості тонкостінних сталевих балок, без розкріплення і з розкріпленням, представлені в роботах $[1,2]$ та працях інших дослідників. До основних джерел, де зазначено результати досліджень кручення та стійкості балок, можна віднести роботи представників німецької класичної технічної школи $[3,4,5]$. Застосування енергетичного методу до задач стійкості отримало бурхливий розвиток у теперішній час і супроводжується реалізацією обчислювальних методів на комп'ютері [6]. Визначення еквівалентних навантажень на стабілізуючі конструкції приводиться в дисертації [7] та статті [8]. Розрахунку балок при згині та крученні за одним із варіантом теорії другого порядку присвячено роботу [9]. Дану тематику розкрито також у статті [10]. 
Виділення не розв'язаних раніше частин загальної проблеми. Не розв'язаною раніше частиною загальної важливої проблеми $\epsilon$ виділення тих моментів, на які потрібно звертати увагу при розрахунку розкріплених елементів, особливо прогонів легкої похилої покрівлі, для відповідності побудованої моделі дійсній роботі балок при складному опорі. Відчутної економії можна досягти внаслідок урахування зменшення впливу скатної складової навантаження на напруження від згину за рахунок наявності розкріплення.

Постановка мети і задач досліджень. Складність математичного описання функції згинально-крутильного бімоменту часто призводить до спрощень і аналітичних помилок у процесі визначення внутрішніх зусиль, які залежать від функції кута закручування стрижня. Тому на основі набутого досвіду в частині аналізу внутрішніх зусиль із урахуванням особливостей умов роботи конструкції з недосконалостям при сумісній дії поперечного згину та кручення було вирішено уточнити модель визначення несучої здатності розкріплених сталевих елементів різного перерізу. Потребують подальшого теоретичного дослідження та вирішення задачі виявлення причин і наслідків виникнення кручення, вивчення природи його появи та способів контролю або мінімізації.

Основний матеріал і результати. При безперервному бічному розкріпленні з певною жорсткістю на зсув верхній пояс зміщується від зовнішнього і еквівалентного навантажень. Деформація верхнього поясу виникає внаслідок податливості кріплення. Взявши за основу положення теорії другого порядку і змінену модель стиснутого стрижня з урахуванням розподілу згинального моменту в балці, було отримано спрощений вираз для визначення максимального зміщення верхнього поясу закріпленої настилом балки $v_{o c, m}$, який призводить до незначного завищення результатів, що йде в запас міцності, але є простим у застосуванні. Податливість кріплення верхнього поясу може бути врахована наближено через прийняття на вихідній стадії розрахунку початкового викривлення балки, зміненого на величину максимального зміщення верхнього поясу, яке включає деформації балки під навантаженням i надалі може визначатися поступовим наближенням до потрібного значення із заданою точністю. В уточненій формулі EN 1993-1-1 (1) при зменшенні викривлення за абсолютною величиною використовується знак «+», при збільшенні за рахунок малої скатної складової або при додатному попередньому викривленні - знак «-»:

$$
\bar{v}_{0, m}=v_{0, m}+v_{o c, m} \approx v_{0, m}+\frac{-M_{z}+N_{E d} v_{0, m}}{S \pm N_{E d}},
$$

де $v_{0, m}$ - максимальне початкове викривлення балки, котре визначається залежно від виду кривої викривлення, перерізу і прольоту балки, а також виду розрахунку ( $e_{0}$ відповідно до позначень EN 1993-1-1); при спрямуванні викривлення проти напрямку осі $y$ його величина прийнята за логікою від’ємною;

$$
N_{E d}=\frac{C_{d} M_{y}}{h_{s}}-\text { поздовжня стискувальна сила у верхньому поясі балки з урахуванням }
$$

розподілу згинального моменту в балці (для рівномірно розподіленого навантаження за власними розрахунками при прийнятті кривої початкового викривлення за квадратну параболу $C_{d}=0,833$, або згідно з [7] при прийнятті кривої початкового викривлення за синусоїду $C_{d}=0,885 ; h_{s}$ - відстань по висоті між центрами ваги поясів балки);

$S$ - зсувна жорсткість розкріплення (профільованого настилу) на одну балку.

Важливішим варіантом напрямку початкового викривлення $\epsilon$ той випадок, при якому воно призводить до невигідного збільшення крутного навантаження, тобто для розкріпленого швелера спрямоване вверх по схилу проти напрямку осі найменшої жорсткості та має від'ємний знак. Додатне початкове викривлення призводить до зменшення загального крутного навантаження при такій розрахунковій схемі та менших загальних напружень, що є менш небезпечним випадком розрахунку, проте є також актуальним для розкріпленої двотаврової балки при відсутності ексцентриситету і перекосу переважаючої складової поперечного навантаження (в площині найбільшої жорсткості профілю). 
Напружено-деформований стан попередньо викривленої і закрученої тонкостінної балки, завантаженої рівномірно розподіленим поперечним навантаженням у двох площинах, 3 урахуванням закріплення балки від поперечних зміщень, а також висоти прикладення навантаження у загальному вигляді можна описати за допомогою просторової моделі для опису стабілізуючих еквівалентних навантажень із поширеною системою диференційних рівнянь рівноваги стрижня, взятої з роботи [7] (без впливу поздовжньої сили, також система відрізняється додаванням частини другого рівняння, що описує кручення балки, котре залежить від місця прикладення скатної складової навантаження):

$$
\left\{\begin{array}{l}
E I_{z} v^{I V}+\left(M_{y}\left(\vartheta_{0}+\vartheta\right)\right)^{\prime \prime}=q_{y} ; \\
E I_{\omega} \vartheta^{I V}-G I_{t} \vartheta^{\prime \prime}+c_{\vartheta} \vartheta+q_{z} z_{P}\left(\vartheta_{0}+\vartheta\right)+M_{y}\left(v_{0}+v\right)^{\prime \prime}+q_{y} y_{P}\left(\vartheta_{0}+\vartheta\right)=m_{x},
\end{array}\right.
$$

де $\vartheta_{0}, v_{0}$ - початкові кут закручування і викривлення балки;

$\vartheta, v-$ кут закручування і викривлення балки під навантаженням;

$E, G$ - модулі пружності та зсуву відповідно;

$I_{z}, I_{\omega}$ - момент інерції відносно осі $z$ і секторіальний момент інерції перерізу балки;

$I_{t}$ - момент інерції перерізу при вільному крученні;

$c_{\vartheta}$ - крутильна жорсткість розкріплення (профільованого настилу);

$z_{P}, y_{P}-$ координати точки прикладення навантаження відносно центра згину балки; при прикладенні переважаючої складової поперечного навантаження до верхнього поясу $z_{P} \approx-0,5 h_{s}$; для швелера при прикладенні скатної складової навантаження в місці кріплення профільованого настилу до прогону в рівні верхнього поясу по центру ваги перерізу $y_{P} \approx-\left(e-0,5 t_{w}+e_{y}\right)$, де $e-$ відстань від центра стінки до центра згину; $t_{w}-$ товщина стінки балки; $e_{y}$ - відстань по осі $y$ від центра ваги $C$ до лівої грані стінки (таблична величина);

$q_{z}, q_{y}$ - рівномірно розподілені поперечні навантаження, що діють вздовж осі $z$ і $y$ відповідно (для прогону - проекції розрахункового рівномірно розподіленого навантаження $q$ на вісь $z$ і $y: q_{z}=q \cos \alpha ; q_{y}=q \sin \alpha$, де $\alpha$ - кут нахилу перерізу); при збігові напрямку дії навантаження з напрямком осі знак приймається додатний;

$m_{x}$ - рівномірно розподілене крутне навантаження відносно центра згину 3 урахуванням правила знаків при крученні $\left(m_{x}=q_{z} e_{z}-q_{y} z_{P}=q_{z} e_{z}+0,5 q_{y} h_{s}\right.$, де $e_{z}-$ плече навантаження $q_{z}$, яке для швелерної балки може прикладатися посередині ширини полички $b_{f}$, або посередині стінки в рівні верхнього поясу; $e_{z}=-\left(e-0,5 t_{w}+0,5 b_{f}\right)$, або $e_{z}=-e$, що до кінця не з'ясовано, проте перший варіант призводить до збільшення запасу міцності балки).

Додаткові деформації закручування виникають від згинального моменту в площині найменшої жорсткості, який довантажує прогнуту балку в зворотну сторону від дії податливості з нерівномірним по довжині ексцентриситетом, рівним сумі їі розрахункового прогину $w$ та початкового прогину $w_{0}$ (див. рис. 1$)$. Цим чинником $\left(M_{z}\left(w_{0}+w\right)\right.$ ') за великим рахунком можна знехтувати, як було зроблено в $[7,8]$, оскільки він не суттєво впливає на кінцевий результат, але дозволяє підвищити його точність. Оскільки прогин та викривлення балки незалежні одне від іншого, систему записують без рівняння, що описує прогин балки:

$$
E I_{y} w^{I V}+\left(M_{z}\left(\vartheta_{0}+\vartheta\right)\right)^{\prime \prime}=q_{z},
$$

де $I_{y}$ - момент інерції перерізу балки відносно осі $y$.

Знаючи деформації $\vartheta, v$ та похідні від них, можна за допомогою рівнянь системи встановити внутрішні зусилля, необхідні для визначення несучої здатності елемента. При зміні згинального моменту по довжині балки диференційне рівняння задачі сумісної дії поперечного згину і кручення не має замкненого відносно простого розв'язку. 

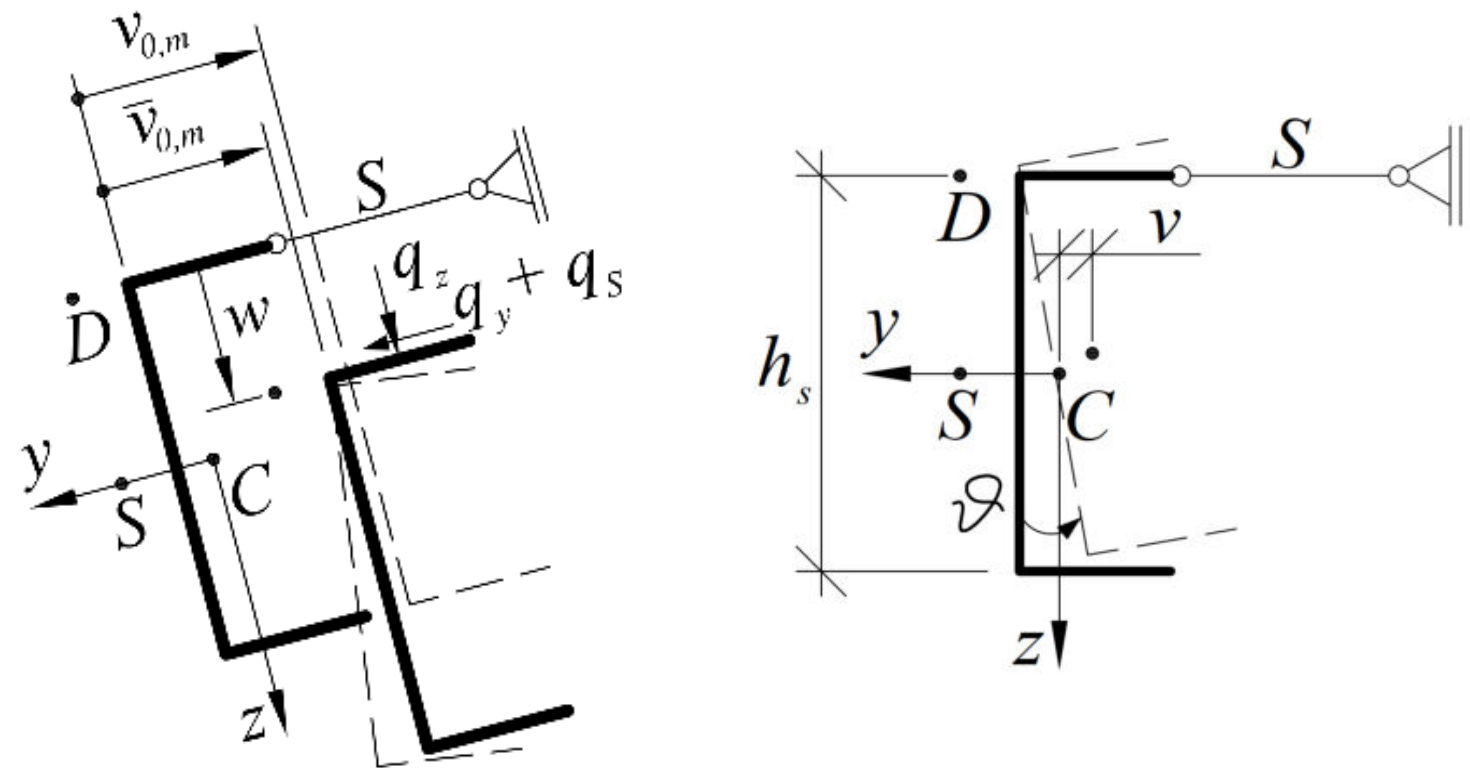

Рис. 1. Навантаження та деформації для розкріпленої швелерної балки; взаємозв'язок лінійних і кутових деформацій

Вважається, що при достатній зсувній жорсткості розкріплення стиснутий пояс практично повністю закріплений від поперечних зміщень і вісь обертання, котру в цьому випадку називають зв'язаною, розташовується над центром згину на рівні верхньої полички елемента. При введенні передумови існування в балці зв'язаної осі обертання за рахунок наявності достатньої зсувної жорсткості приєднаних конструкцій деформації $v$ та $\vartheta$ вже не $\epsilon$ незалежними одна від іншої. Тому можна ввести спрощення, справедливе при малих кутах закручування (знак «-» передбачає закріплення в площині верхнього поясу, лінійна деформація відраховується від центра ваги - рис. 1):

$$
v=-\frac{h_{s}}{2} \vartheta .
$$

При безперервному бічному закріпленні з певною жорсткістю на зсув верхній пояс всетаки дещо зміщується від навантаження в площині найменшої жорсткості. Якщо врахувати зміщення верхнього поясу балки $v_{o c}$, що виникло внаслідок податливості кріплення, у формі синусоїди, то замість викривлення $v$ слід застосовувати його змінене сумарне значення:

$$
\bar{v}=v+v_{o c}=v+v_{o c, m} \sin \left(\frac{\pi x}{L}\right) .
$$

Навантаження $q_{z}$ i $q_{y}$ передаються на балку через приєднані до верхнього поясу конструкції. Щоб знайти необхідні деформації застосуємо для балки 3 прикладеним в рівні верхнього поясу поперечним навантаженням умову рівності нулю сумарної елементарної можливої (віртуальної) роботи на основі принципу можливих переміщень і системи диференційних рівнянь рівноваги стрижня при відсутності початкового кута закручування балки. Виконавши попередньо заміну скатної складової навантаження на вираз із першого рівняння системи (2) і перетворення при відкритті дужок для другої похідної від добутку функцій, а також скорочення частин крутного навантаження від точки прикладення переважаючої складової поперечного навантаження, отримаємо вираз для роботи:

$$
\begin{aligned}
& \delta W=\delta W_{e}+\delta W_{g}+\delta W_{p}=-\int_{0}^{L}\left(\left(E I_{z} \frac{h_{s}^{2}}{4}+E I_{\omega}\right) \vartheta^{\prime \prime} \delta \vartheta^{\prime \prime}+G I_{t} \vartheta^{\prime} \delta \vartheta^{\prime}+\left(c_{\vartheta}+q_{y} y_{P}\right) \vartheta \delta \vartheta\right) d x- \\
& -\int_{0}^{L}\left(M_{y} h_{s} \vartheta^{\prime} \delta \vartheta^{\prime}\right) d x+\int_{0}^{L}\left(V_{z} h_{s} \vartheta^{\prime} \delta \vartheta\right) d x+\int_{0}^{L}(m \delta \vartheta) d x=0,
\end{aligned}
$$

де $V_{z}=-q_{z} x+q_{z} \frac{L}{2}-$ поперечна сила по довжині балки в напрямку осі $z$. 
Крутне навантаження $m$ за умови відсутності початкового прогину балки становитиме:

$$
m=-M_{y} \bar{v}_{0}^{\prime \prime}-M_{z} w^{\prime \prime}+q_{z} e_{z}+E I_{z} v_{o c}^{I V} \frac{h_{s}}{2} .
$$

Записавши рівняння (3) у вигляді основного диференційного рівняння зігнутої осі (пружної лінії) балки у просторовій постановці $E I_{y} w^{\prime \prime}=-M_{y}-M_{z}\left(\vartheta_{0}+\vartheta\right)$ і виразивши 3 нього другу похідну від функції прогину, рівняння (7) за умови прийняття кривої початкового викривлення за синусоїду перепишемо у вигляді:

$$
m=M_{y} \bar{v}_{0, m} \frac{\pi^{2}}{L^{2}} \sin \left(\frac{\pi x}{L}\right)+M_{z}\left(\frac{M_{y}}{E I_{y}}+\frac{M_{z} \vartheta}{E I_{y}}\right)+q_{z} e_{z}-E I_{z} v_{o c, m} \frac{\pi^{4}}{L^{4}} \sin \left(\frac{\pi x}{L}\right) \frac{h_{s}}{2} .
$$

Якщо прийняти криву початкового викривлення за квадратну параболу, вираз для відшукування крутного навантаження буде мати вигляд:

$$
m=M_{y} \bar{v}_{0, m} \frac{8}{L^{2}}+M_{z}\left(\frac{M_{y}}{E I_{y}}+\frac{M_{z} \vartheta}{E I_{y}}\right)+q_{z} e_{z}-E I_{z} v_{o c, m} \frac{\pi^{4}}{L^{4}} \sin \left(\frac{\pi x}{L}\right) \frac{h_{s}}{2} .
$$

Будемо розглядати лише найпоширенішу симетричну балкову схему завантаження у вигляді рівномірно розподіленого по всій довжині навантаження. Тоді згинальні моменти по довжині балки відносно осі $y$ і z за теорією першого порядку будуть визначатись так:

$$
\begin{gathered}
M_{y}=-\frac{q_{z} x^{2}}{2}+\frac{q_{z} L}{2} x ; \\
M_{z}=\frac{q_{y} x^{2}}{2}-\frac{q_{y} L}{2} x .
\end{gathered}
$$

Згідно з джерелом [3] і прийнятими спрощеннями зсувна жорсткість не виконує роботу, але призводить до появи додаткового скатного навантаження. При заміні скатної складової навантаження на вираз із першого рівняння системи (2) крутні зусилля, обумовлені зсувною жорсткістю, врівноважуються. Перше рівняння системи (2) запишеться таким чином:

$$
E I_{z}\left(-0,5 h_{s} \vartheta^{I V}+v_{o c}^{I V}\right)+\left(M_{y}\left(\vartheta_{0}+\vartheta\right)\right)^{\prime \prime}-S v_{o c}^{\prime \prime}=q_{y} .
$$

Деформований стан балки при крученні опишемо за допомогою виразу для кута закручування із трьома підібраними для зручності операцій диференціювання та інтегрування параметрами, один з яких виявиться нульовим $\left(\vartheta_{2}=0\right)$ :

$$
\vartheta=\sum_{j=1}^{3} \vartheta_{j} \sin \left(\frac{j \pi x}{L}\right)
$$

Вираз із одним параметром призводить до занадто високої похибки при визначенні згинально-крутильного бімоменту, бо не відповідає його епюрі. Можливість застосування виразу з трьома параметрами, один 3 яких нульовий, для опису деформацій балки при крученні з достатньо високою точністю доведена у роботі [8].

Похідні від кута закручування $\vartheta^{\prime}, \vartheta^{\prime \prime}$ і $\delta \vartheta$ після диференціювання будуть дорівнювати:

$$
\begin{gathered}
\vartheta^{\prime}=\sum_{j=1}^{3} \vartheta_{j} \frac{j \pi}{L} \cos \left(\frac{j \pi x}{L}\right) ; \\
\vartheta^{\prime \prime}=-\sum_{j=1}^{3} \vartheta_{j}\left(\frac{j \pi}{L}\right)^{2} \sin \left(\frac{j \pi x}{L}\right) ; \\
\delta \vartheta=\sum_{j=1}^{3} \delta \vartheta_{j} \sin \left(\frac{j \pi x}{L}\right) .
\end{gathered}
$$

Після введення виразів (13) - (16) у рівняння для віртуальної роботи і виконання інтегрування стає можливим отримати матричне рівняння для визначення кута закручування 3 невідомими параметрами, що відшукуються методом Крамера. 3 огляду на громіздкість виразів при інтегруванні, яке було виконано за допомогою системи комп'ютерної алгебри Maxima, наведемо тільки кінцеві формули в табл. 1. 
Таблиця 1 - Визначення кута закручування матричним способом

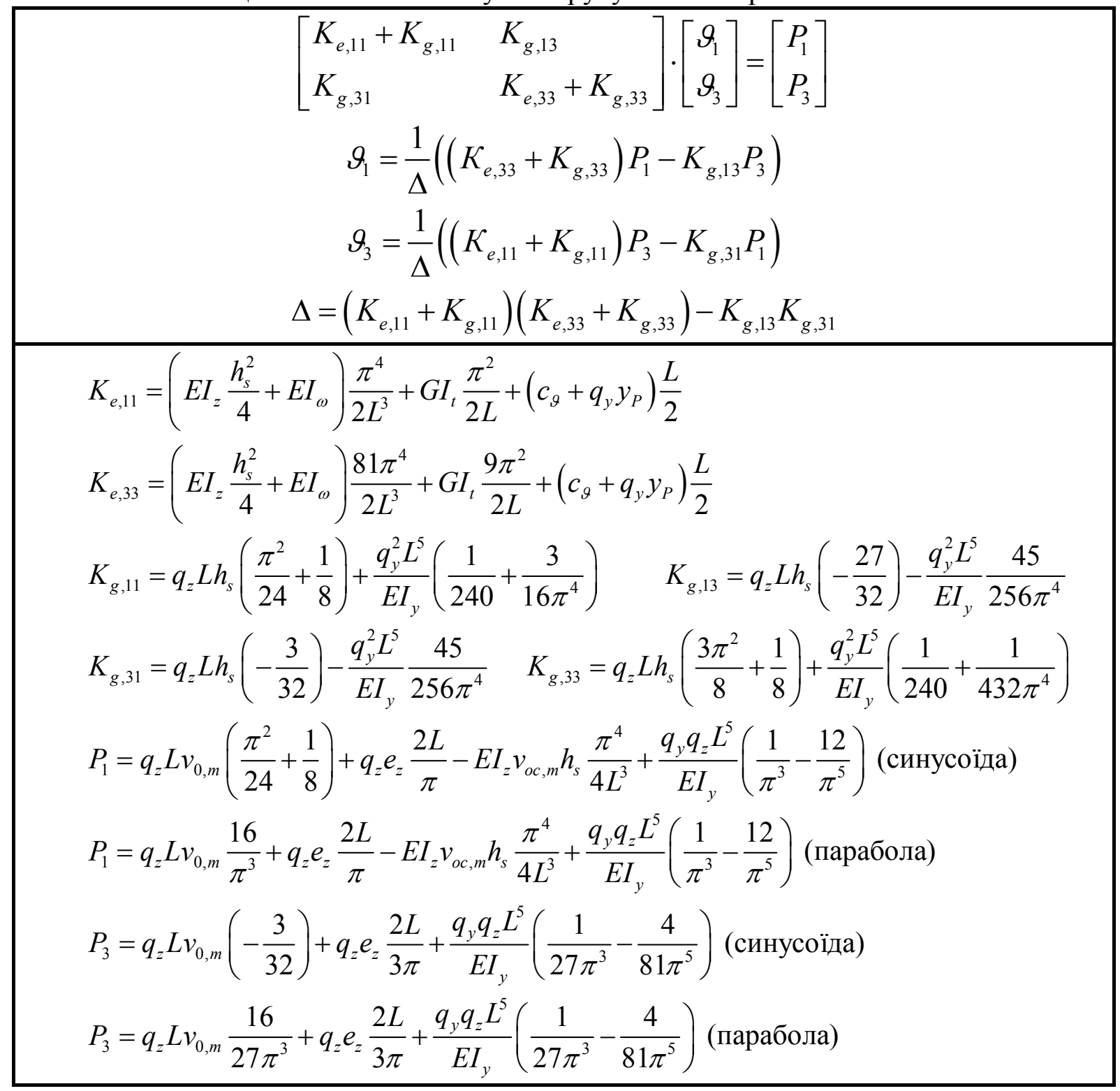

Для визначення зміщення застосуємо до нашого випадку рівняння (12). Виконавши інтегрування, отримаємо вираз для ітераційного відшукування уточненого максимального значення деформації зміщення верхнього поясу балки за деформованою схемою 3 урахуванням кута закручування та напрямку дії. Беручи до уваги прийняті спрощення, формула після перетворень набуде такого вигляду:

$$
v_{o c, m}=\frac{1}{S}\left(\frac{q_{y} L^{2}}{8}+\frac{q_{z} L^{2}}{8}\left(\vartheta_{1}-\vartheta_{3}\right)+\frac{\pi^{2} E I_{z}}{L^{2}}\left(\frac{h_{s}}{2}\left(\vartheta_{1}-9 \vartheta_{3}\right)-v_{o c, m}\right)\right) .
$$

Розрахункові згинальні моменти $M_{y}^{I I}, M_{z}^{I I}$ відносно осі $y$ i z за теорією другого порядку визначаються з урахуванням кута закручування стрижня і зсувної жорсткості розкріплення:

$$
\begin{gathered}
M_{y}^{I I}=M_{y}+M_{z} \vartheta ; \\
M_{z}^{I I}=M_{z}-M_{y} \vartheta+S v_{o c} .
\end{gathered}
$$

Важливо відзначити, що в дійсності розрахунковий бімомент залежить не тільки від навантаження, його ексцентриситету, пружної згинально-крутильної константи перерізу i прольоту балки, але також і від жорсткості приєднаних до балки конструкцій. Бімомент за теорією другого порядку пропорційний другій похідній від кута закручування стрижня:

$$
M_{\omega}^{I I}=-E I_{\omega} \vartheta^{\prime \prime} .
$$


Для точного розрахунку, як відомо, потрібно детально проаналізувати напружений стан i перевірити напруження в найбільш напруженій точці перерізу балки. Найбільші абсолютні значення напружень в розгорнутій формулі варто визначати у двох протилежних крайніх точках, де виникають напруження від згину у двох площинах одного знаку. Рівняння для визначення нормальних напружень у загальному вигляді буде мати таку форму:

$$
\sigma(z, y, \omega)=\frac{M_{y}^{I I}}{I_{y}} z-\frac{M_{z}^{I I}}{I_{z}} y+\frac{M_{\omega}^{I I}}{I_{\omega}} \omega,
$$

де $z, y, \omega$ - декартові координати розглядуваної точки поперечного перерізу, в якій визначаються напруження, відносно центра ваги та секторіальна координата в цій точці.

Перевіримо наведену модель, порівнявши результати різних розрахунків 3 даними моделювання методом скінченних елементів у програмах ConSteel 13, FE-STAB, Dlubal RSTAB 8.19.01 (додатковий модуль FE-LTB) із аналізом другого порядку. Порівняння внутрішніх зусиль і нормальних напружень для двох розкріплених балок зведемо до табл. 2. Проліт швелерної і двотаврової балок із близькою площею поперечного перерізу становив 6 м, а вертикальне навантаження на них складало 8 кН/м (кут нахилу покрівлі $\alpha$ різний).

Таблиця 2 - Порівняння моделі розрахунку з чисельним експериментом

\begin{tabular}{|c|c|c|c|c|c|c|}
\hline $\begin{array}{c}\text { Переріз, } \\
\text { площа }\end{array}$ & $\alpha,{ }^{\circ}$ & Метод, теорія & $M_{y}$, кНсм & $M_{z}$, кНсм & $M_{\omega}, \mathrm{\kappa Hсм}^{2}$ & $\sigma, \mathrm{M \Pi а}$ \\
\hline \multirow{15}{*}{$\begin{array}{c}\text { Швелер } \\
\text { UPE } 200 \\
\text { A }= \\
29,01 \\
\text { см }^{2}\end{array}$} & \multirow{5}{*}{5} & розвинена модель & 3674 & -100 & -756 & $226 / 1,00$ \\
\hline & & MCE ConSteel 13 & 3672 & -108 & -860 & $229 / 1,01$ \\
\hline & & MCE FE-STAB & 3698 & -109 & -835 & $227 / 1,00$ \\
\hline & & MCE FE-LTB & 3624 & -91 & -662 & $219 / 0,97$ \\
\hline & & тонкостінних стрижнів & 3586 & -314 & -1594 & $264 / 1,17$ \\
\hline & \multirow{5}{*}{15} & розвинена модель & 3572 & -135 & -788 & $226 / 1,00$ \\
\hline & & MCE ConSteel 13 & 3555 & -130 & -810 & $224 / 0,99$ \\
\hline & & MCE FE-STAB & 3580 & -132 & -804 & $223 / 0,99$ \\
\hline & & MCE FE-LTB & 3513 & -104 & -699 & $216 / 0,96$ \\
\hline & & тонкостінних стрижнів & 3477 & -932 & -1078 & $412 / 1,82$ \\
\hline & \multirow{5}{*}{30} & розвинена модель & 3208 & -168 & -796 & $211 / 1,00$ \\
\hline & & MCE ConSteel 13 & 3176 & -147 & -710 & $204 / 0,97$ \\
\hline & & MCE FE-STAB & 3197 & -152 & -730 & $203 / 0,96$ \\
\hline & & MCE FE-LTB & 3147 & -111 & -721 & $198 / 0,94$ \\
\hline & & тонкостінних стрижнів & 3118 & -1800 & -248 & $677 / 3,21$ \\
\hline \multirow{15}{*}{$\begin{array}{c}\text { Двотавр } \\
\text { IPE } 200 \\
\mathrm{~A}= \\
28,48 \\
\mathrm{~cm}^{2}\end{array}$} & \multirow{5}{*}{5} & розвинена модель & 3588 & -25 & -154 & $199 / 1,00$ \\
\hline & & MCE ConSteel 13 & 3590 & -20 & -130 & $197 / 0,99$ \\
\hline & & MCE FE-STAB & 3587 & -76 & -127 & $216 / 1,09$ \\
\hline & & MCE FE-LTB & 3589 & -9 & -94 & $192 / 0,96$ \\
\hline & & тонкостінних стрижнів & 3586 & -314 & 328 & $-307 /-1,54$ \\
\hline & \multirow{5}{*}{15} & розвинена модель & 3480 & -49 & -188 & $203 / 1,00$ \\
\hline & & MCE ConSteel 13 & 3480 & -36 & -100 & $196 / 0,97$ \\
\hline & & MCE FE-STAB & 3477 & -74 & -103 & $209 / 1,03$ \\
\hline & & MCE FE-LTB & 3479 & -15 & -160 & $191 / 0,94$ \\
\hline & & тонкостінних стрижнів & 3477 & -932 & 969 & $-541 /-2,67$ \\
\hline & \multirow{5}{*}{30} & розвинена модель & 3122 & -73 & -232 & $195 / 1,00$ \\
\hline & & MCE ConSteel 13 & 3120 & -50 & -80 & $181 / 0,93$ \\
\hline & & MCE FE-STAB & 3118 & -70 & -78 & $188 / 0,96$ \\
\hline & & MCE FE-LTB & 3119 & -18 & -246 & $176 / 0,90$ \\
\hline & & тонкостінних стрижнів & 3118 & -1800 & 1872 & $-861 /-4,42$ \\
\hline
\end{tabular}


При моделюванні у програмі Dlubal RSTAB 8.19.01 початкове викривлення задавалось у вигляді рівномірно розподіленого крутного навантаження (аналіз за додатковими силами):

$$
m_{v}=k_{i} q_{z} v_{0, m},
$$

де $k_{i}$ - коефіцієнт, що враховує нерівномірність початкового викривлення по довжині балки; згідно 3 [4] приймається із запасом 0,85, але при рівності інтегралів від нерівномірного початкового викривлення у формі синусоїди та рівномірного отримується цифра $2 / \pi \approx 0,637$, у формі параболи $-2 / 3=0,667$.

Модуль пружності та границя текучості сталі приймалися постійними $\left(E=2,1 \cdot 10^{5}\right.$ МПа, $f_{y}=235 \mathrm{MПа).} \mathrm{Величина} \mathrm{початкового} \mathrm{викривлення} \mathrm{становила} \mathrm{для} \mathrm{швелера} 1,5$ см $(0,5 l / 200)$, крива стійкості - $c$, для двотавра 1,2 см (0,5l/250), крива стійкості - $b$ згідно з EN 1993-1-1 при пружному розрахунку. Криву початкового викривлення прийнято за синусоїду. Довжина області зсуву складається з чотирьох кроків покрівельного несучого профільованого настилу FI + 100/275 - 0.75 | Fischer FI із горизонтальною проекцією 3 м, який з'єднується 3 прогоном через хвилю, забезпечуючи таким чином достатню крутильну жорсткість за критерієм Фогеля/Гейла завдяки наявності зменшеної порівняно з EN 1993-1-1 потрібної зсувної жорсткості для прийняття зв’язаної осі обертання стрижня.

Згідно з теорією тонкостінних стрижнів урахування кручення для швелерних прогонів дає зменшення розрахункових нормальних напружень у середньому на $15 \%$ порівняно зі згином у двох площинах. Зусилля, що виникають від ексцентричності прикріплення балки болтами на опорах, можуть теоретично знизити напруження в небезпечному перерізі більш ніж у два рази (для похилих прогонів, прикріплених стінкою). В дійсності ж це зниження буде значно меншим внаслідок нещільності болтових з'єднань. Наші власні підрахунки цих зусиль 3 урахуванням стандартних зазорів між болтом і отвором для різних класів точності болтового з'єднання (отримане поздовжнє зусилля зменшувалось на величину, що відповідає деформації, рівній зазору) на основі уточненої моделі з урахуванням жорсткості приєднаних конструкцій показали, що несуча здатність прогонів не збільшується, тому цей вплив враховувати недоцільно. Тим не менш, швелер вважається оптимальною формою перерізу для похилої покрівлі. У реальній розкріпленій конструкції профільований настил збільшує крутильну і згинальну жорсткість прогону проти викривлення, тому ефект буде іншим.

Висновки. Розрахунки показали, що, навіть при кріпленні профільованого настилу через хвилю, згинальний момент у площині найменшої жорсткості суттєво зменшується (для швелера при кутах нахилу покрівлі 5 - 30 більш ніж в 3 рази, для двотавра - більш ніж в 12 раз) i його вплив на загальний напружено-деформований стан конструкції практично нівелюється. Нормальні напруження для двотавра виявились відчутно нижчими (на 8 - 12\%). Тому двотавр може вважатися оптимальною формою поперечного перерізу прокатного прогону і для похилої покрівлі внаслідок зменшення негативної дії крутного навантаження. Порівняння свідчить про те, що розвинена модель розрахунку балки за теорією другого порядку відповідає чисельному експерименту i добре узгоджується 3 ним. Незначна розбіжність результатів пояснюється спрощеними передумовами при розрахунку, до того ж, вона в більшості випадків йде в незначний запас міцності, на відміну від теорії тонкостінних стрижнів, яка придатна тільки для нерозкріплених балок у зв'язку 3 прийняттям занадто простих передумов, які не враховують ефекти другого порядку, жорсткість приєднаних конструкцій і суттєво завищують результат. При визначенні несучої здатності ефективним буде врахування по можливості жорсткості бічних в'язей і пластичної роботи сталі.

\section{Література}

1. Balázs I. and Melcher J., Stability of Thin-Walled Beams with Lateral Continuous Restraint, Transactions of the VŠB-Technical University of Ostrava, Civil Engineering Series, 15(1), (2015), pp.1-10.

2. Put B.M., Pi Y.L. and Trahair N.S., Bending and torsion of cold-formed channel beams, Journal of Structural Engineering, 125(5), (1999), pp.540-546. 
3. Kindmann R., Stahlbau, Teil 2: Stabilität und Theorie II. Ordnung. 4. Auflage, Berlin: Ernst \& Sohn, 2008. - $429 \mathrm{~s}$.

4. Kuhlmann U., Stahlbau-Kalender 2009: Schwerpunkt - Stabilität, Berlin: Ernst \& Sohn, (2009), - $1032 \mathrm{~s}$.

5. Wagenknecht G., Stahlbau-Praxis nach Eurocode 3: Band 1 Tragwerksplanung, Grundlagen, Berlin: Beuth Verlag GmbH, (2011), - 396 s.

6. Kindmann R. and Kraus M., Steel structures: Design using FEM, John Wiley \& Sons, (2011), pp:168-216.

7. Krahwinkel M., Zur Beanspruchung stabilisierender Konstruktionen im Stahlbau, Fortschritt-Berichte VDI, Reihe 4 Bauingenieurwesen, Nr. 166, Düsseldorf: VDI-Verlag, (2001), $182 \mathrm{~s}$.

8. Kindmann R., Bemessung stabilisierender Verbände und Schubfelder / R. Kindmann, M. Krahwinkel // Stahlbau 70 (2001), S. 885 - 899.

9. Frickel J. Bemessung von Trägern unter Biegung und Torsion nach Th. II. Ordnung / J. Frickel // RUBSTAHL-Bericht 2-2002, Ruhr-Universität Bochum. - S. 89-94.

10. Hudz S., The Problem of Consideration Torsion Emergence in Beams / S. Hudz, G. Gasii, V. Pents // International Journal of Engineering \& Technology, 7 (3.2) (2018), pp:141-148.

\section{References}

[1] Balázs I. and Melcher J., Stability of Thin-Walled Beams with Lateral Continuous Restraint, Transactions of the VŠB-Technical University of Ostrava, Civil Engineering Series, 15(1), 2015.

[2] Put B.M., Pi Y.L. and Trahair N.S., Bending and torsion of cold-formed channel beams, Journal of Structural Engineering, 125(5), 1999.

[3] Kindmann R., Stahlbau, Teil 2: Stabilität und Theorie II. Ordnung. 4. Auflage, Berlin: Ernst \& Sohn, 2008.

[4] Kuhlmann U., Stahlbau-Kalender 2009: Schwerpunkt - Stabilität, Berlin: Ernst \& Sohn, 2009.

[5] Wagenknecht G., Stahlbau-Praxis nach Eurocode 3: Band 1 Tragwerksplanung, Grundlagen, Berlin: Beuth Verlag GmbH, 2011.

[6] Kindmann R. and Kraus M., Steel structures: Design using FEM, John Wiley \& Sons, 2011.

[7] Krahwinkel M., Zur Beanspruchung stabilisierender Konstruktionen im Stahlbau, FortschrittBerichte VDI, Reihe 4 Bauingenieurwesen, Nr. 166, Düsseldorf: VDI-Verlag, 2001.

[8] Kindmann R., Bemessung stabilisierender Verbände und Schubfelder / R. Kindmann, M. Krahwinkel // Stahlbau 70, 2001.

[9] Frickel J. Bemessung von Trägern unter Biegung und Torsion nach Th. II. Ordnung / J. Frickel // RUBSTAHL-Bericht 2-2002.

[10] Hudz S., The Problem of Consideration Torsion Emergence in Beams / S. Hudz, G. Gasii, V. Pents // International Journal of Engineering \& Technology, 7 (3.2) 2018.

\section{РАЗВИТАЯ МОДЕЛЬ РАСЧЕТА СТАЛЬНЫХ РАСКРЕПЛЁННЫХ ЭЛЕМЕНТОВ НА УСТОЙЧИВОСТЬ ПРИ СОВМЕСТНОМ ДЕЙСТВИИ ПОПЕРЕЧНОГО ИЗГИБА И КРУЧЕНИЯ}

Гудзь С.А., к.т.н., доцент goods.sergiy@gmail.com ORCID 0000-0002-4764-8635 Национальный университет «Полтавская политехника имени Юрия Кондратюка»

Гасий Г.М., д.Т.н., доцент grigoriigm@gmail.com ORCID 0000-0002-1492-0460 Сумской национальный аграрный университет Дариенко В.В., к.т.н., доцент vvdarienko@gmail.com ORCID 0000-0001-9023-6030 Центральноукраинский национальный технический университет 
Аннотация. В статье рассмотрены основные этапы расчета стальных раскрепленных изгибаемых элементов с начальными несовершенствами по деформированной схеме. Раскрепление может происходить с помощью присоединенных к стальной балке конструкций. На основе нового подхода к анализу внутренних силовых факторов была поставлена цель найти и описать особенности эксплуатации балки при совместном действии поперечного изгиба и кручения. Была усовершенствована существующая теоретическая модель с устранением присутствующих в ней недостатков. На примерах проведено сравнение методик определения несущей способности по устойчивости гибких элементов. Было предложено увеличить экономию материала путем детализации расчета.

Ключевые слова: бимомент, искривление, устойчивость, кручение, раскрепление.

\title{
DEVELOPED MODEL OF STEEL RESTRAINED ELEMENTS DESIGN FOR STABILITY BY THE COMPATIBLE ACTION OF TRANSVERSE BENDING AND TORSION
}

\author{
Hudz S.A., Ph.D., Assistant Professor \\ goods.sergiy@gmail.com ORCID 0000-0002-4764-8635 \\ National University «Yuri Kondratyuk Poltava Polytechnic» \\ Gasii G.M., Ph.D., Assistant Professor \\ grigoriigm@gmail.com ORCID 0000-0002-1492-0460 \\ Sumy National Agrarian University \\ Darienko V.V., Ph.D., Assistant Professor \\ vvdarienko@gmail.com ORCID 0000-0001-9023-6030 \\ Central Ukrainian National Technical University
}

\begin{abstract}
The main stages of the calculation of steel restrained flexible elements with initial imperfections are considered according to the deformed scheme. Restraint can occur using structures attached to the steel beam, such as profiled flooring, which is attached with self-tapping screws. The goal to find and describe the features of beam operation under the combined action of transverse bending and torsion was set on the basis of a new approach to the analysis of internal force factors. The existing theoretical model has been improved to eliminate the deficiencies present in it. A comparison of the methods for determining the bearing capacity of flexible elements by stability was carried out using examples. It was proposed to increase material savings by detailing the calculation. The moments to which you need to pay attention when calculating the restrained elements, especially the purlins of a light inclined roof, were highlighted to match the constructed model with the real work of beams with complex resistance. The complexity of the mathematical description of the bending-torsional bimoment function often leads to simplifications and analytical errors in the process of determining the internal forces, which depend on the function of the rod angle of rotation. Therefore, it was decided to clarify the model for determining the bearing capacity of restrained steel elements of various cross-sections. The tasks of identifying the causes and consequences of the occurrence of torsion, studying methods of control or minimization require further theoretical research and solutions. It is proved that the calculated bimoment depends not only on the load, its eccentricity, the elastic bending-torsional constant of the cross-section and span of the beam, but also on the stiffness of the structures laterally attached to the beam. The optimal cross-sectional shape of the rolled purlin for an inclined roof was justified, namely the I-beam, due to a decrease in the negative effect of the torsion load.
\end{abstract}

Keywords: bimoment, curvature, stability, buckling, torsion, restraint. 


\title{
ФІЗИЧНА МОДЕЛЬ РОБОТИ СИСТЕМИ «МЕТАЛЕВА ПОПЕРЕДНЬО НАПРУЖЕНА ОБОЙМА ПІДСИЛЕННЯ - ПОШКОДЖЕНА ЗАЛІЗОБЕТОННА БАЛКА»
}

\author{
Карпюк В. М., д.т.н., професор, \\ ORCID: 0000-0002-4088-6489 \\ Даниленко Д.С., аспірант, \\ ddsnauka@gmail.com, ORCID: 0000-0002-7517-5767 \\ Карпюк I.А., к.т.н., доцент, \\ ORCID: 0000-0003-3437-5882 \\ Даниленко А.В., к.т.н., асистент, \\ ORCID: 0000-0002-0204-6972 \\ Сьоміна Ю.А., к.т.н., асистент, \\ Одеська державна академія будівництва та архітектури \\ ORCID: 0000-0002-6330-0137
}

\begin{abstract}
Анотація. Представлені результати системних експериментальних досліджень несучої здатності, деформативності та тріщиностійкості пошкоджених залізобетонних балок, підсилених попередньо напруженими металевими обоймами, при статичному та малоцикловому знакозмінному навантаженнях високих рівнів. Зокрема, наведені експериментально-статистичні залежності міцності похилих перерізів (руйнуючої поперечної сили), стріли прогинів та ширини розкриття нормальних і похилих тріщин перед руйнуванням балок, довжини проекції небезпечних похилих тріщин на повздовжню вісь та середньої відстані між нормальними тріщинами по довжині елементів від конструктивних чинників та факторів зовнішньої дії. Усі дослідні зразки-балки були виготовлені та випробувані згідно з теорією планування експерименту за Д-оптимальним планом Бокса В4.

Ключові слова: пошкоджена силовими тріщинами залізобетонна балка, металева попередньо напружена обойма, малоциклове знакозмінне навантаження.
\end{abstract}

Вступ. Підвищення сейсмічності територій, на яких розташовані будівлі та споруди, їхнього фізичного зносу 3 накопиченням пошкоджень $\mathrm{i}$ зміною функціонального призначення зі збільшенням навантажень на них потребує прийняття нестандартних рішень. Заміна пошкоджених залізобетонних конструкцій вимагає значних трудових ресурсів, фінансових витрат і зупинки виробництва на тривалий час. Разом з тим, аналіз пошкоджень, що характеризують «життєдіяльність» прогінної залізобетонної конструкції, споруди чи будівлі, в цілому, показав, що у процесі іiі експлуатації відбувається значне руйнування захисного шару бетону, корозія арматури, утворення i надмірне розкриття тріщин, досягнення недопустимих прогинів тощо.

Накопичений досвід показав, що експлуатацію і «життєвий цикл» пошкоджених конструкцій можна продовжити за рахунок їх підсилення і відновлення у процесі проведення капітального ремонту без зупинки технологічного процесу.

Підсилення залізобетонних конструкцій за допомогою армованих бетонних або розчинних сумішей окрім збільшення їх ваги та інших відомих незручностей має такі недоліки: включення системи підсилення в сумісну роботу з пошкодженим елементом можливе тільки після набору достатньої міцності матеріалами нарощування перерізів; відсутність повного контролю за сумісною роботою пошкодженої конструкції та системи підсилення.

Останнім часом все частіше застосовується підсилення конструкцій наклеєними композитними матеріалами. Проте, висока вартість цих матеріалів, відсутність прямого контролю за якістю підсилення, чутливість до температурних впливів, можливість крихкого 
руйнування приопорних ділянок та недосконалість існуючих методів їх розрахунку стримують можливість більш широкого використання цього прогресивного, в цілому, методу підсилення пошкоджених конструкцій.

Більшість прогінних залізобетонних конструкцій під час експлуатації зазнає дії циклічних або малоциклових повторних та знакозмінних навантажень, які виникають у межах експлуатаційного рівня, а інколи й перевищують його. Зміна знака навантаження, його рівня та невизначене повторення в процесі експлуатації часто призводить до наслідків, якісно відмінних від отриманих при розрахунку на стале навантаження одного знаку максимальної інтенсивності, на яке орієнтовані більшість діючих норм проектування. Підсилення пошкоджених наскрізними нормальними і похилими перехресними надмірно розкритими тріщинами балкових залізобетонних конструкцій, доведених в процесі вказаної вище експлуатації до граничного або передаварійного стану, за дії зростаючого циклічного навантаження високих рівнів без зупинки технологічного процесу виробництва за допомогою попередньо напружених металевих обойм $\epsilon$ безальтернативним. Проте, проектування такого підсилення стримується відсутністю нормативної методики та чітких рекомендацій в авторських методиках, які адекватно б відображали реальний напруженодеформований стан як пошкодженої конструкції, так і елементів підсилення. Цим i зумовлена актуальність даної роботи.

Аналіз останніх джерел досліджень і публікацій. Експериментально [1] встановлено, малоциклове знакозмінне та знакопостійне навантаження високих рівнів не тільки зменшує несучу здатність дослідних зразків - залізобетонних балок до 20\% та їхню тріщиностійкість, суттєво збільшує ширину розкриття нормальних i, особливо, похилих тріщин, величину прогинів до $35 \%$, а також змінює характер їх руйнування порівняно 3 одноразовим статичним пропорційно зростаючим навантаженням. При багатократному циклічному навантаженні за несприятливих умов абсолютна межа витривалості бетону i арматури зменшується до 50\% від їх розрахункового опору, внаслідок чого ще більше зменшується тріщіностійкість та несуча здатність таких конструкцій, збільшується їхня деформативність та прискорюється процес руйнування.

Очевидно, що для підсилення залізобетонних конструкцій, доведених в таких умовах експлуатації до граничного або аварійного стану, слід використовувати метал, як один із найбільш вивчених матеріалів зі стабільними міцнісними і фізико-хімічними показниками, які легко контролювати. При цьому, наявність пластичних властивостей у сталі сприяє перерозподілу внутрішніх зусиль між елементами підсилення та пошкодженою конструкцією.

Розглянемо існуючі способи підсилення пошкоджених залізобетонних конструкцій 3 використанням сталевих пристроїв. Відомий спосіб підсилення залізобетонної конструкції [2] шляхом прикріплення додаткової арматури до оголеної робочої арматури розтягнутої зони, попереднього їі натягу "на бетон" і наступного обетонування. Проте, у даному способі попередньо стискається розтягнута зона, а тому збільшується опірність тільки розтягнутої зони елемента, що згинається, тобто має місце неповне підсилення пошкодженої конструкції , що веде до часткового і не завжди прийнятного (при підвищених статичних, пульсуючих або сейсмічних впливах) збільшення несучої здатності конструкції, що підсилюється.

Серед багатьох інших способів заслуговує уваги спосіб [3], який передбачає закріплення елемента підсилення в стиснутій зоні залізобетонної балки і подальше двостадійне його попереднє стиснення: до і після попереднього напруження елемента підсилення розтягнутої зони. Однак, даний спосіб дозволяє підсилити тільки нормальні перерізи цільної (без тріщин) залізобетонної балки на дію тільки знакопостійного поперечного навантаження або згинального моменту в головній вертикальній силовій площині і не призводить до підсилення похилих перерізів і приопорних ділянок, в цілому, на дію того ж знакопостійного навантаження. А при впливі знакозмінного поперечного навантаження (наприклад, під час землетрусу) цей спосіб, навпаки, може призвести до 
передчасного руйнування як за нормальними, попередньо розтягнутими верхніми елементами підсилення перерізами, так і за перехресними похилими перерізами.

Одним із перших у Радянському Союзі проф. Пинаджян В.В. [4] вивчав можливість застосування різних металевих пристроїв для підсилення прогінних залізобетонних конструкцій. Зокрема, він встановив, що підсилення пошкодженої таврової залізобетонної балки під навантаженням армованою розчинною "сорочкою" підвищило іiі несучу здатність на $42 \%$, а підсилення такої ж балки за допомогою попередньо напружених повздовжніх сталевих стержнів на 8\%; підсилення іiі за допомогою двох описаних вище пристроїв одночасно - на 71\%, а підсилення балки тільки на приопорних ділянках попередньо напруженими U-подібними хомутами - на 10\%. Для більш надійного з'єднання старого 3 новим бетоном автор [4] рекомендує встановлювати додаткові металеві зв'язки для запобігання їх взаємного зсуву. Він стверджував, що підсилення розтягнутої зони конструкції попередньо напруженою поздовжньою арматурою у вигляді шпренгельної затяжки є одним із найбільш ефективних пристроїв.

Цей висновок підтвердили випробовування [5] залізобетонних балок, підсилених попередньо напруженими металевими затяжками, які показали одночасне збільшення їхньої несучої здатності та жорсткості зі збільшенням поперечного перерізу затяжок. Випробовування автором [5] підсилених двопролітних балок показали, що попередньо напружені затяжки перетворювали балки в позацентрово стиснуті елементи, а також виявили залежність перерозподілу внутрішніх зусиль у балці від величини стискаючих зусиль у затяжках. Ці випробування також підтвердили доцільність створення попереднього напруження і у вертикальних поперечних стержнях.

Детальна кваліфікація найбільш розповсюджених причин та технічних станів будівельних конструкцій, які підкреслюють необхідність їх підсилення, а також методів їх здійснення наведена у роботі [6]. Вона містить у собі повний набір різноманітних пристроїв підсилення залізобетонних конструкцій, завдяки чому стала незамінною книгою багатьох фахівців у галузі реконструкції. Проте, як виявилося, наведений у [6] атлас схем і креслень все ж не містить пристроїв для підсилення аварійних конструкцій за дії циклічного знакозмінного або його зростаючого навантаження.

Відома конструкція пристрою [7] для підсилення залізобетонної балки з приклеєним до iii нижньої грані металевим листом і пов'язаними 3 нею попередньо напруженими горизонтальними елементами у вигляді двох гнучких тяжів на бічних поверхнях, напруження в яких створюється шляхом затягування (напруження) вертикальних елементів, заанкерених у верхній стиснутій зоні. Однак, за допомогою описаної вище конструкції можна підсилити тільки нижню розтягнуту зону та приопорні ділянки балки за сталого або знакопостійного циклічного поперечного навантаження.

Оригінальний пристрій для підсилення будівельних конструкцій, що згинаються [8], містить жорсткий хвилеподібний елемент підсилення, напружені вертикальні хомути, напружену арматуру і опорні котки. Елемент підсилення прикріплений кінцями на опорах і в місцях дотику до підсилюваної конструкції, що згинається, з боку стиснутої зони. Поздовжня напружена арматура закріплена в торцях конструкції, що підсилюється, а опорні котки розташовані між напруженою арматурою і розтягнутою гранню конструкції. Висота підйому гребенів хвилеподібного елемента підсилення виконана зі зменшенням від середини до кінців конструкції, що підсилюється 3 охопленням напруженої арматури між опорними котками. Хомут виготовлений у вигляді сережки з різьбовими ділянками на кінцях для гайок 3 установкою перемички. При закручуванні гайок відбувається натягування хомутів i арматури. Обтиснення конструкції здійснюють від іiі середини до країв. При цьому, верхня стиснута зона частково розвантажується, а в нижній арматурі підсилення створюється момент, протилежний за знаком моменту від зовнішнього навантаження. Отже, даний пристрій дозволяє підсилити верхню стиснуту і нижню розтягнуту зони, а також, частково, приопорні ділянки, внаслідок чого підвищується іiї несуча здатність, але за дії поперечного навантаження тільки одного знака. 
Представляє інтерес підсилення залізобетонних стиснутих та зігнутих елементів за допомогою стальних листів, прикріплених по їх боках болтовим з'єднанням [9]. У цій роботі автори встановили зв'язок між проковзуванням болтового з'єднання та несучою здатністю балки. Зважаючи на циклічний характер навантаження, автори $[10,11,12]$ підкреслюють як позитивну якість роботи даного пристрою, так і пластичний характер руйнування підсиленої конструкції.

Проведені експериментальні дослідження [13] підсиленої шляхом приклеювання стальної смуги на непошкоджену залізобетонну балку показали приріст її несучої здатності до 300\%. При цьому, автори [13] продовжують дослідження по закріпленню кінців смуг підсилення 3 метою більш повного використання їх міцності та запобігання крихкого руйнування балки.

Автори [14] випробували чотири балки: одну - без підсилення; другу, підсилену знизу у розтягнутій зоні приклеєною стальною смугою; третю, підсилену у стиснутій та розтягнутій зонах аналогічними стальними смугами без приклеювання їх до тіла балки;четверту, підсилену такими ж смугами зверху і знизу, приклеєними до тіла балки за допомогою епоксидного клею. Усі підсиленні балки мали однакове анкерне кріплення стальних пластин на їх торцях. Відзначається підвищення несучої здатності на $130 \ldots 160 \%$, зменшення деформативності підсилених на епоксидному клею балок і пластичний характер їх руйнування. А балка, підсилена металевими пластинами без їх приклеювання, працювала як балка із затяжкою і мала підвищену деформативність.

Експериментальні дослідження [15] трьох залізобетонних балок, підсилених стальним листом, розташованим у розтягнутій зоні та прикріплених за допомогою конічних анкерів і епоксидного клею, показали підвищення несучої здатності до 48\%. А в роботі [16] вказується на те, що застосування аналогічного пристрою підсилення (тільки з іншою конструкцією анкера) дало підвищення несучої здатності тільки на 10\% порівняно з балкою без анкерного кріплення.

За результатами експериментальних досліджень пристрою підсилення зовнішньою стержнево-котковою шпренгельною системою залізобетонних балок авторами [17] було досягнуто збільшення їхньої несучої здатності до 4,5 разів та суттєво зменшення деформативності.

Будівельні конструкції в момент підсилення, в основному, знаходяться під навантаженням, від величини якого згідно [18] залежить надійність підсиленого залізобетонного елемента. У результаті досліджень напруженого стану залізобетонних балок, підсилених нарощуванням розтягнутої стержневої арматури за дії навантаження авторами [19] були запропоновані дві нові методики оцінки надійності підсилених залізобетонних елементів.

Виділення не розв'язаних раніше частин загальної проблеми. У національних нормах проектування i відомих авторських методиках відсутні чіткі рекомендації 3 розрахунку сумісної роботи пошкоджених і доведених до граничного або аварійного стану прогінних залізобетонних конструкцій 3 елементами попередньо напружених металевих обойм.

Розрахунок металевих елементів підсилення залізобетонних конструкцій у авторських методиках здійснюється згідно існуючих положень чинних норм проектування вказаних конструкцій, у розрахункових формулах яких замість робочої, монтажної та поперечної арматури використовуються повздовжні, поперечні та похилі елементи підсилення без достатнього урахування їх взаємодії 3 пошкодженими конструкціями та реального їх технічного стану, вирівнювання, за потреби, рихтування та придання їм початкової форми у більшості випадків.

Аналіз наявних публікацій показав, що існуючі способи підсилення прогінних залізобетонних конструкцій мають наступні спільні ознаки:

- закріплення елементів підсилення на пошкодженій балці; 
- створення попереднього напруження в ній (балці) в повздовжньому і вертикальному поперечному напрямку.

Пристрої, що використовуються для підсилення прогінних конструкцій, мають такі спільні ознаки:

- поздовжні елементи підсилення;

- поперечні вертикальні елементи підсилення;

- поперечні вертикальні елементи підсилення, з'єднані з поздовжніми елементами підсилення.

Недоліками описаних вище способів та пристроїв підсилення балкових залізобетонних конструкцій являються:

- посилення, в основному, нормальних (частіше) і похилих (рідше) перерізів цільної залізобетонної балки на дію тільки знакопостійного поперечного навантаження в головній площині. При впливі знакозмінного навантаження більшість існуючих способів та пристроїв може призвести до передчасного руйнування дослідних елементів;

- неспроможність відновити або підвищити, за потреби, несучу здатність аварійних або доведених до граничного стану балкових конструкцій за дії знакозмінного циклічного чи пульсуючого навантаження високих рівнів, або сейсмічних впливів, а також нездатність їх до перерозподілу внутрішніх зусиль в нерозрізних балках.

Порівняння наявних дослідних даних несучої здатності як звичайних, так і підсилених металевими обоймами пошкоджених наскрізними нормальними і перехресними похилими тріщинами залізобетонних балок за дії малоциклового знакозмінного навантаження високих рівнів з результатами розрахунків за існуючими авторськими методиками показало, в цілому, незадовільну їх збіжність як для звичайних, так і підсилених дослідних балок. При цьому, основна частина публікацій приходиться на визначення несучої здатності нормальних перерізів звичайних і підсилених металевими елементами конструкцій за першими і другими групами граничних станів, в той час як міцність їхніх похилих перерізів та приопорних ділянок, в цілому, залишається ще далеко не вивченою.

Постановка завдання. Мета даної роботи полягає в експериментально-теоретичному дослідженні несучої здатності, тріщиностійкості та деформативності підсилених попередньо напруженими металевими обоймами пошкоджених наскрізними нормальними $\mathrm{i}$ перехресними похилими тріщинами залізобетонних балок за дії малоциклового знакозмінного навантаження високих рівнів для вдосконалення існуючих та подальшої розробки нової фізичної і математичної моделей несучої здатності нормальних і похилих перерізів пошкоджених прогінних залізобетонних конструкцій, в тому числі під час бойових дій.

Завдання досліджень:

- розробити оригінальний спосіб відновлення та підсилення пошкоджених наскрізними нормальними і перехресними похилими тріщинами залізобетонних балок і пристрій для його здійснення, а також отримати, по можливості, відповідний патент на винахід;

- вивчити напружено-деформований стан, несучу здатність, ширину розкриття нормальних i похилих тріщин, прогинів, характеру руйнування звичайних цільних i підсилених попередньо напруженими металевими обоймами залізобетонних балок, які отримали суттєві пошкодження і були доведені майже до руйнування у попередніх дослідженнях за дії статичного і малоциклового знакозмінного навантаження високих рівнів з використанням теорії планування експерименту;

- дослідити вплив основних конструктивних чинників на несучу здатність приопорних ділянок дослідних звичайних та підсилених попередньо напруженими металевими обоймами пошкоджених залізобетонних балок, їхню тріщиностійкість та деформативність за допомогою експериментально-статистичних залежностей, отриманих у процесі обробки одержаних даних;

- зробити порівняльний аналіз впливу основних конструктивних чинників на вказані параметри звичайних цільних і підсилених попередньо напруженими металевими обоймами 
пошкоджених залізобетонних балок 3 урахуванням дії статичного i малоциклового знакозмінного навантаження.

Методика проведення експериментів, матеріалів та обладнання. В Одеській державній академії будівництва та архітектури проводяться системні експериментальні дослідження $[1,20,21,22]$ несучої здатності приопорних ділянок складнонапружених залізобетонних прогінних конструкцій. Для досягнення вказаної мети в академії були створені спосіб та пристрій для відновлення і підсилення пошкоджених залізобетонних балок, що знаходяться у передаварійному стані внаслідок їх поділу наскрізними нормальними і перехресними похилими тріщинами на окремі блоки, з'єднані між собою поздовжньою і поперечною арматурою за дії знакозмінного циклічного чи пульсуючого навантаження високих рівнів, а також підсилення звичайної прогінної залізобетонної конструкції, яка хоча й знаходиться у задовільному технічному стані, проте може зазнати вказаного навантаження або сейсмічних впливів [23]. Поставлена задача була вирішена двома винаходами, об'єднаними єдиним задумом:

a) способом відновлення і підсилення пошкодженої залізобетонної балки шляхом закріплення елементів підсилення на ній 3 подальшим створенням в них попереднього напруження і тристороннього іï (балки) обтиснення;

б) пристроєм для відновлення і підсилення пошкодженої балки, що містить з'єднані між собою поздовжні та поперечні вертикальні і горизонтальні елементи, стягнуті між собою різьбовими муфтами.

Заявлений спосіб відновлення та підсилення пошкоджених залізобетонних балок і пристрій для його здійснення забезпечують наступний технічний результат:

1. Повне відновлення пошкодженої балки.

2. Підвищення, за необхідності, несучої здатності підсиленої попередньо напруженою металевою обоймою залізобетонної балки.

3. Здійснюються значна економія матеріально-технічних ресурсів за рахунок заощадження відновлення і посилення, у разі необхідності, існуючих балкових конструкцій на навантаження, яке змінилося, в тому числі зростаюче, знакозмінне, пульсуюче або інше динамічне навантаження.

4. Роботи з монтажу пристрою і способу його включення в роботу не вимагають зупинки основного технологічного процесу.

Виходячи 3 наведеного вище додатково була реалізована ще одна серія натурних дослідів з однопрогінними пошкодженими у попередніх експериментах балками, підсилених попередньо напруженими металевими обоймами за дії малоциклового знакозмінного навантаження високих рівнів з використанням теорії планування експерименту та ефективної комп'ютерної програми СОМРЕХ проф. Вознесенського В.А.

Із літературних джерел відомо, що основні параметри працездатності залізобетонних конструкцій підпорядковані нормальному закону розподілу Гаусса і при їхній обробці можна застосовувати метод найменших квадратів. Оскільки дослідні фактори можуть впливати на функцію "виходу" нелінійно, то іiї доцільно аппроксимувати поліномом другого ступеня. Тому дослідні зразки були виготовленні та двічі випробувані за чотирьохфакторним трирівневим Д-оптимальним планом Бокса В-4 [24], який забезпечує однакову точність прогнозу вихідного параметра з області, яка описується радіусом, що дорівнює умовній "1" відносно центральної "нульової" точки.

У якості дослідних обрані наступні фактори (конструктивні чинники), які змінювалися на трьох рівнях:

$\mathrm{X}_{1}$ - відносний проліт зрізу ( віддаль від опори до лінії дії зосередженої сили), $\mathrm{a} / \mathrm{h}_{0}=1,2,3$ при $\mathrm{h}_{0}=\mathrm{d}=175$ мм;

$\mathrm{X}_{2}$ - клас бетону C, МПа, C16/20, С30/35, C40/50;

$\mathrm{X}_{3}$ - коефіцієнт поперечного армування: зовнішньої металевої обойми $\rho_{\mathrm{fw}}(\mathrm{A} 240 \mathrm{C})=0,0046 ; 0,0105 ; 0,0263 ; \rho_{\mathrm{sw}}(\mathrm{BpI})=0,0016 ; 0,0029 ; 0,0044$; 
$\mathrm{X}_{4}$ - рівень зовнішнього поперечного навантаження в залізобетонних балках першої (АСД) та другої серії (А) $\eta_{1,2}=0,5 ; 0,65 ; 0,80$; рівень попереднього напруження в елементах обойми $\eta_{\sigma f}=0,25 ; 0,50 ; 0,75$.

Коефіцієнти верхнього і нижнього повздовжнього армування $\rho_{\mathrm{ls}}=\rho_{\mathrm{ls}}=0,176$ для усіх типів балок. Коефіцієнти верхнього i нижнього додаткового армування пошкоджених залізобетонних балок у вигляді попередньо напружених елементів обойми із кутиків $25 \mathrm{x} 25 \mathrm{x} 4$ $\rho_{\mathrm{ef}}^{\prime}=\rho_{\mathrm{ef}}=0,0191$, при $\mathrm{l}_{0}=9 \mathrm{~h}_{0} ; \mathrm{h}_{0}=175$ мм i $\mathrm{b}=100$ мм для звичайних залізобетонних балок.

Кожен дослід натурного експерименту першої (АСД) та другої (А) серій був забезпечений двома близнюками-балками 3 чотирма приопорними ділянками. Дослідні зразки-балки третьої серії (Д) представляли собою ті ж самі пошкоджені та поділені на окремі блоки наскрізними нормальними і похилими перехресними тріщинами балки другої серії (A), доведені під час попередніх випробувань на дію знакозмінного навантаження високих рівнів до граничного стану і які у третій серії (Д) були відновлені та підсилені запатентованими авторами способом та пристроєм [23]. Отже, усього було виготовлено у перших двох серіях 100 залізобетонних балок і випробувано на дію, відповідно, статично ступенево зростаючого і малоциклового знакозмінного навантаження високих рівнів аж до настання граничного стану, який виникає у дослідних елементах нарівні навантаження $\eta \approx 0,95 \mathrm{~F}_{\text {ult, }}$ тобто напередодні руйнування. А у третій серії (Д) усі відновлені та посилені попередньо напруженими металевими обоймами [23] пошкоджені дослідні зразки-балки другої серії (А) повторно були випробувані на дію малоциклового знакозмінного навантаження аж до їх руйнування.

Дослідні зразки-залізобетонні балки були армовані згідно плану експерименту B4 двома плоскими зварними каркасами. Для виготовлення зазначених елементів використовували важкий бетон вказаних вище класів на гранітному щебені фракцій 5-10 мм і кварцовому піску 3 модулями крупності 1,5. В якості в'яжучого застосовували портландцемент марки 500 без добавок. Для зменшення водоцементного відношення, поліпшення легкоукладності бетонної суміші та скорочення термінів набору міцності бетону у всіх дослідах використовували комплексну добавку Релаксол-Супер М у кількості 1\% від ваги цементу в перерахунку на суху речовину.

Для відновлення і підсилення пошкоджених силовими тріщинами залізобетонних балок згідно патенту на винахід №119294 [23] були виготовлені спеціальні пристрої для його здійснення заявленим способом, а для випробовування - сертифікована спеціальна силова установка. Навантаження у циклах прикладали за чотирьохточковою схемою за допомогою гідравлічного домкрату ДГ-50 і двох розподільних балок-траверс двома зосередженими силами ступенями: по $(0,04 \ldots 0,06) \mathrm{F}_{\text {ult }}$ до появи перших нормальних і похилих тріщин, a потім - по $(0,08 \ldots 0,12) \mathrm{F}_{\text {ult }}$ до руйнування у першій серії (АСД) або до заданого рівня $\eta$ знакозмінного навантаження у першому його циклі, а згодом - аж до руйнування на завершальному етапі у другій (А) та третій (Д) серіях. Витримка навантаження на ступені становила до 15 хвилин зі всіма вимірами на початку й наприкінці кожної ступені навантаження.

Перед бетонуванням дослідних балок на розтягнуту арматуру одного із плоских каркасів були наклеєні ланцюжки тензорезисторів КФ5П1-5-200 (з базою 5 мм).

Деформації бетону дослідних зразків вимірювали за допомогою дротяних та фольгових тензорезисторів з базою 40 і 50 мм, приклеєних за загальноприйнятою методикою на одну бічну і верхню відшліфовані грані.

Деформації повздовжніх і поперечних елементів попередньо напруженої металевої обойми вимірювали також за допомогою аналогічних тензорезисторів. Перехід від виміряних у досліді деформацій в арматурі і елементах обойми здійснювали за допомогою закону Гука, а в бетоні - за січним модулем пружності.

Контроль за деформаціями бетону стислої зони й розтягнутої арматури, а також за рівнем попереднього напруження у металевій обоймі здійснювали за допомогою індикаторів годинникового типу, а вертикальними переміщеннями - прогиномірів Аістова. 
Основний матеріал і результати. Випробування дослідних залізобетонних зразківбалок першої (АСД) і другої (А) серій показало, що їхнє деформування , тріщиноутворення та руйнування відбулося за правилами будівельної механіки і було прогнозованим. Першими появлялися нормальні тріщини в зоні дії максимальних згинальних моментів. 3 подальшим збільшенням поперечного навантаження нормальні тріщини розвивалися в глиб балки, збільшувалася ширина їх розкриття й появлялися нові нормальні тріщини. Подальше збільшення статичного ступенево зростаючого навантаження призводило до подальшого розвитку нормальних і похилих тріщин з переважним розкриттям похилих аж до руйнування балок першої (АСД) серії за небезпечними похилими тріщинами.

Дослідні зразки-балки першої (АСД) і другої (А) серій були запроектовані майже рівноміцними за нормальними та похилими перерізами, але так, щоби їх руйнування відбувалося, все-таки, за похилими перерізами під дією на завершальному етапі їхньої роботи руйнуючих поперечних сил та, пов'язаних з ними, згинальних моментів.

Під час зміни знаку напівцикла навантаження балок другої (А) серії раніше утворені нормальні і похилі тріщини повністю закривалися під дією стискаючих напружень у зміненій iз розтягнутої у попередньому напівциклі зони на стиснуту. I навпаки, у раніше стиснутій зоні "чистого згину" у наступному напівциклі появляються нові нормальні тріщини, які з'єднуються 3 попередніми нормальними, утворюючі видимі наскрізні тріщини у стані спокою. А на приопорних ділянках зі зміною знаку напівциклу з'являються нові похилі тріщини, які перетинають раніше утворені похилі тріщини під кутом, близьким до $90^{\circ}$, що добре пояснюється напрямком головних розтягуючих напружень.

Зі збільшенням рівнів знакозмінного навантаження поступово збільшувалася висота нормальних і довжина похилих небезпечних тріщин, погіршувалося зчеплення бетону 3 поздовжньою і поперечною арматурою, відбувалося розущільнення бетону і зниження його міцності, мало місце збільшення ширини розкриття тріщин, деформативності дослідних зразків-балок та взаємне зміщення окремих їх блоків. Руйнування балок другої (А) серії на високих рівнях $\eta \geq 0,8 \mathrm{~F}_{\text {ult }}$ носило, як правило, крихкий характер і відбувалося, в основному, на приопорних ділянках.

Відновлення і підсилення пошкоджених у другій (А) серії балок за допомогою заявлених в [23] способу і пристрою дозволило спочатку їх вирівняти і придати їм початкову форму, потім суттєво їх відновити і підсилити, що в результаті, як показали досліди третьої (Д) серії, дозволило значно підвищити їхню несучу здатність та підтвердити доцільність застосування вказаного винаходу на практиці.

У результаті отриманих експериментальних даних, вилучення незначимих та перерахунку тих коефіцієнтів, що залишилися, за допомогою ефективної компютерної програми COMPЕХ отримали адекватні експериментально-статистичні залежності основних параметрів працездатності дослідних зразків розглянутих серій, які мають добру інформаційну корисність та показують гарну збіжність 3 дослідними даними.

Міцність (несуча здатність) дослідних елементів може бути представлена наступними експериментальними залежностями:

$$
\begin{array}{lr}
\hat{Y}\left(V_{\mathrm{u} 1}^{\text {exp }}\right)=98-41 X_{1}+12 X_{2}+6 X_{3}+16 X_{1}^{2}-7 X_{2}^{2}-5 X_{3}^{2}-7 X_{1} X_{2}, k H, & v=5,2 \% ; \\
\hat{Y}\left(V_{\mathrm{u} 2}^{\text {exp }}\right)=80-33 X_{1}+13 X_{2}+6 X_{3}-2 X_{4}+21 X_{1}^{2}-12 X_{2}^{2}-5 X_{3}^{2}-7 X_{1} X_{2}, k H & v=5,8 \% ;(2) \\
\hat{Y}\left(V_{\mathrm{uf}}^{\text {exp }}\right)=148-32 X_{1}+17 X_{2}+2 X_{1}^{2}-8 X_{2}^{2}-10 X_{1} X_{2}, k H & v=5,3 \% ;
\end{array}
$$

де $\mathrm{V}_{\mathrm{u} 1}^{\exp }, \mathrm{V}_{\mathrm{u} 2}^{\exp }$ - руйнуюча поперечна сила, відповідно, при статистичному ступенево зростаючому і малоцикловому знакозмінному навантаженнях звичайних залізобетонних балок за [1];

$\mathrm{V}_{\mathrm{uf}}^{\mathrm{exp}}$ - руйнуюча поперечна сила пошкоджених силовими нормальними i похилими тріщинами залізобетонних балок другої серії (А), підсилених попередньо напруженими металевими обоймами згідно з [23], за дії малоциклового знакозмінного навантаження високих рівнів при тих же значеннях конструктивних чинників.

$$
-60-
$$


Представлені адекватні експериментально-статистичні залежності (1) ... (3), названі проф. Вознесенським В.А. математичними моделями [24], мають суттєву перевагу над кореляційними та іншими залежностями тому, що вони дозволяють комплексно оцінити вплив кожного зазначеного вище фактора на визначальні вихідні параметри не тільки зокрема, а й у взаємодії один $з$ одним, а також порівняти величину цього впливу як на звичайні залізобетонні балки за дії статичного ступенево зростаючого і малоциклового знакозмінного навантаження високих рівнів, так і на підсилені металевими попередньо напруженими обоймами пошкоджених і розділених силовими тріщинами на окремі блоки залізобетонних балок за дії аналогічного навантаження.

Серед конструктивних чинників найбільший вплив на несучу здатність приопорних ділянок дослідних елементів має величина відносного прольоту зрізу. В цілому, підтверджується виявлена О.С. Залєсовим, Ю.А. Климовим [25], В.М. Карпюком [20, 21, 22] та іншими дослідниками закономірність зменшення міцності похилих перерізів залізобетонних балкових конструкцій зі збільшенням прольоту зрізу за нелінійним законом.

Наступним за величиною $є$ клас бетону. При цьому, при збільшенні класу від C16/20 до C40/50 несуча здатність зростає також за нелінійним законом. Аналогічна картина спостерігається і 3 підвищенням коефіцієнтів поперечного армування $\rho_{\mathrm{sw}}, \rho_{\mathrm{fw}}$. Вплив збільшення рівня поперечного навантаження $\eta$ від 0,5 до 0,8 виявився негативним при знакозмінному його характері тільки для звичайних балок другої (А) серії.

Аналіз залежностей (1) ... (3) показує, що вони є якісно однотипними і вплив конструктивних чинників, а також фактора малоциклового навантаження $є$ якісно подібним. Відмінності спостерігаються у кількісних показниках. Так, несуча здатність похилих перерізів дослідних зразків-балок, виражена через руйнуючу поперечну силу $\mathrm{V}_{\mathrm{u}}$, збільшується по відношенню до середніх їхніх значень (вільних членів $\mathrm{b}_{0}$ ), відповідно, 98, 80 i $148 \mathrm{kH}$ :

- зі зменшенням величини відносного прольоту зрізу а/ $\mathrm{h}_{0}$ від 3 до 1 у першій (АСД), другій (А) і третій (Д) серіях на 84,83 і 43\%;

- зі збільшенням класу бетону від С16/20 до С40/50, відповідно на 24, 33 і 23\%;

- зі збільшенням кількості поперечної сталевої арматури $\rho_{\mathrm{sw}}$ від 0,0016 до 0,0044 (вирази (1), (2)) на 12 і 15\%;

- зі збільшенням кількості попередньо напружених поперечних хомутів металевої обойми $\rho_{\mathrm{fw}}$ від 0,0046 до 0,0263 значення $\mathrm{V}_{\mathrm{uf}}^{\mathrm{exp}}$ залишається сталим, очевидно, із-за ефекта сумісної роботи усіх попередньо напружених елементів металевої обойми та частково відновленої шляхом тристороннього обтиснення попередньо пошкодженої залізобетонної балки;

- при зменшенні рівня малоциклового знакозмінного навантаження $\eta$ від 0,8 до 0,5 у залізобетонних балках другої (А) серії на 5\%;

Наявність квадратичних ефектів при факторах $\mathrm{X}_{1}^{2}, \mathrm{X}_{2}^{2}$ i $\mathrm{X}_{3}^{2}$ зі знаками, протилежними прямому впливу вказаних чинників, свідчить про те, що за межами зміни дослідних факторів $\left(\mathrm{a} / \mathrm{h}_{0}>3, \mathrm{C}>40 / 50 \mathrm{MПа}, \rho_{\mathrm{sw}}>0,0044 \mathrm{i} \rho_{\mathrm{fw}}>0,0263\right)$ подальше збільшення $\mathrm{a} / \mathrm{h}_{0}$ не призведе до суттєвого зниження несучої здатності (руйнуючої поперечної сили), а подальше збільшення класу бетону C та кількості поперечної сталевої арматури $\rho_{s w}$ i попередньо напружених зовнішніх хомутів $\rho_{\mathrm{fw}} \in$ недоцільним, оскільки процес збільшення $\mathrm{V}_{\mathrm{u}}$, при цьому, носить затухаючий характер.

Аналіз отриманих експериментальних даних показав, що малоциклове повторне навантаження знижує несучу здатність приопорних ділянок залізобетонних балок, в середньому, на 8\% згідно [22], а малоциклове знакозмінне - аж на 18\% порівняно 3 несучою здатністю аналогічних балок, випробуваних на статичне ступенево зростаюче навантаження. Цей висновок підтверджується працями професорів Бабича Є.М., Масюка Г.Х. та їхніх учнів.

Як показали натурні експериментальні дослідження, несуча здатність підсилених попередньо напруженими металевими обоймами [23], пошкоджених у попередніх дослідах 
залізобетонних балок, в середньому, підвищилась на 51\% порівняно зі звичайними залізобетонними балками першої серії (АСД), що свідчить про високу ефетивність такого підсилення.

Кількість циклів повторного і знакозмінного навантаження у проведених дослідах була продиктована критерієм стабілізації деформацій у бетоні проф. Бабича Є.М. і склала не менше 10, якщо дослідні зразки-балки не зруйнувалися при меншому числі циклів.

Абсолютна більшість дослідних балок зруйнувалися за похилими перерізами в обох або одному (частіше) із прольотів зрізу. Критерієм руйнування дослідних зразків слугували досягнення граничних деформацій в бетоні або арматурі з явними ознаками виникнення в них пластичних деформацій, надмірне розкриття (до 1 мм і більше) похилих (частіше) або нормальних (рідше) тріщин, суттєве збільшення стріли прогинів $\left(\mathrm{f} \geq \frac{1}{100} 1_{0}\right)$, відсутність приросту або деякий спад (до 15\%) показів манометра насосної станції силової установки.

Експериментально доказано, що основною причиною зниження несучої здатності експериментальних зразків-балок при малоцикловому повторному i знакозмінному навантаженнях $\epsilon$ порушення структури бетону, особливо на приопорних ділянках, його розущільнення та часткова втрата зчеплення з арматурою.

Найбільший приріст залишкових деформацій у бетоні й поперечній арматурі спостерігається на перших двох- трьох циклах і, як правило, вони стабілізуються до пятогошостого циклів при рівнях навантаження $\eta=0 \ldots 0,65$. А в деяких зразках з мінімальним класом бетону і кількістю поперечної арматури при рівнях навантаження $\eta=0 \ldots 0,8$ вказані деформації не стабілізувалися і балки руйнувалися на 6 ..9 циклах від досягнення втомної міцності або можливого зниження їхніх міцнісних параметрів внаслідок статистичної похибки при визначенні руйнуючого однократного ступенево зростаючого навантаження.

Непереармовані $\left(\rho_{\mathrm{sw}} \leq 0,003(\mathrm{BpI}), \rho_{\mathrm{fw}} \leq 0,018\right.$ (A240C)) залізобетонні дослідні балки при однократному ступенево-зростаючому статичному, малоцикловому повторному та знакозмінному навантаженнях $[1,21,22]$, як правило, руйнувалися за схемою В/M, тобто за похилими перерізами при переважній дії згинального моменту внаслідок текучості поздовжньої робочої арматури в усті небезпечної похилої тріщини та поперечної арматури, що перетинається нею. Зі збільшенням кількості поперечної арматури $\rho_{\mathrm{sw}} \geq 0,0044$ аналогічні дослідні елементи з середніми $\left(\mathrm{a} / \mathrm{h}_{0}=2\right)$ і великими $\left(\mathrm{a} / \mathrm{h}_{0}=3\right)$ прольотами зрізу руйнувалися за схемою $\mathrm{C} / \mathrm{V}$, тобто за похилою тріщиною при переважній дії поперечної сили внаслідок текучості поперечної арматури та зрізу або зминання бетону стиснутої сили над вершиною небезпечної похилої тріщини. При малих прольотах зрізу $\left(\mathrm{a} / \mathrm{h}_{0} \leq 1\right)$ дослідні залізобетонні балки руйнувалися, як правило, за схемою Д/см за похилою стислою смугою між двома похилими тріщинами внаслідок роздроблення бетону в цій смузі за траєкторією головних стискаючих напружень або його зрізу під впливом максимальних дотичних напружень.

Руйнування підсилених балок третьої (Д) серії починалося 3 поступової втрати попереднього напруження в стиснутих елементах обойми, розкриття раніше утворених тріщин, взаємного зміщення окремих блоків та надмірного деформування елементів обойми $\mathrm{i}$ завершувалося втратою форми приопорної ділянки.

Прогини дослідних балок перед їх руйнуванням можуть бути охарактеризовані адекватними експериментально-статистичними залежностямми основних параметрів деформативності контрольних звичайних та посилених балок:

$$
\begin{aligned}
& \hat{Y}\left(f_{u 1}^{\exp }\right)=6+1,5 X_{1}+0,65 X_{2}+0,7 X_{3}+0,35 X_{4}-0,5 X_{1}^{2}+0,2 X_{1} X_{3}, \mathrm{Mm} \\
& v=5,5 \% \text {; } \\
& \hat{\mathrm{Y}}\left(\mathrm{f}_{\mathrm{u} 2}^{\exp }\right)=7,2+2,1 \mathrm{X}_{1}+0,8 \mathrm{X}_{2}+0,8 \mathrm{X}_{3}+0,4 \mathrm{X}_{4}-0,5 \mathrm{X}_{1}^{2}, \mathrm{MM} \\
& v=5,3 \% \text {; } \\
& \hat{Y}\left(f_{\text {uf }}^{\text {exp }}\right)=13,2+6,6 X_{1}-0,7 X_{2}+0,85 X_{3}-0,8 X_{4}+1,5 X_{1}^{2}+0,4 X_{2}^{2}+0,6 X_{1} X_{3} \\
& -0,8 \mathrm{X}_{1} \mathrm{X}_{4}+0,9 \mathrm{X}_{2} \mathrm{X}_{4}-0,6 \mathrm{X}_{3} \mathrm{X}_{4}, \mathrm{\text {мм }} \\
& v=5,1 \% ;
\end{aligned}
$$

які показують, що прогини балок першої (АСД) серії дослідів, в середньому, складали (1/263) розрахункового прольоту $1_{0}$, другої (А) серії - (1/219) $1_{0}$, а третьої (Д) серії - (1/119) $1_{0}$. 
При цьому, дія малоциклового знакозмінного навантаження збільшувала прогини дослідних зразків-балок порівняно з одноразовим статистичним ступенево зростаючим навантаженням на 20\%. Серед конструктивних чинників найбільший вплив на прогини випробовуваних $\mathrm{i}$ посилених, елементів має величина відносного прольоту зрізу. 3 ії збільшенням нелінійно зростають прогини. Наступним чинником за величиною впливу $\epsilon$ відсоток поперечного армування. При його збільшенні лінійно зростає несуча здатність дослідних зразків, a, отже, i їхня деформативність. Збільшуючи несучу здатність похилих перерізів, тим самим отримуємо збільшену деформативність. Наступним значущим фактором, для звичайних балок є рівень поперечного навантаження $\eta$, а для посилених балок, - рівень попереднього напруження. Так, при його збільшенні прогини лінійно зменшуються. Завдяки збільшенню класу бетону зростає несуча здатність непошкоджених дослідних зразків, а отже і їхні прогини.

Що стосується кількісних показників, то прогини дослідних зразків-балок, виражені через прогини перед руйнуванням, $\mathrm{f}^{0.95 \mathrm{Fu}}$ збільшується порівняно із середніми їх значеннями 6; 7.2; 13.2 мм, відповідно:

- зі збільшенням величини відносного прольоту зрізу $\mathrm{a} / \mathrm{h}_{0}$ від 1 до 3 у першій, другій та третій серії на 50, 58.3 і $100 \%$;

- при збільшенні класу бетону від C16/20 до C40/50 для першої та другої серії на 21.6 і $22.2 \%$;

- при зменшенні класу бетону для балок третьої серії на 10.6\%;

- зі збільшенням проценту поперечного армування $\rho_{\mathrm{sw}}$ балок від 0.0016 до 0.0044 для балок першої та другої серії, й проценту поперечного армування додатковою арматурою посилення $\rho_{\mathrm{fw}}$ від 0.0046 до 0.0263 у третій серії, відповідно, на 23.3, 22.2 і 12.9\%;

- при збільшенні рівня малоциклового знакозмінного навантаження $\eta$ від 0.5 до 0.8 для першої та другої серії балок на 11.7 і 11.1\%;

- зі зменшенням рівня попереднього напруження в прогінних елементах обойми $\eta_{\sigma f}$ від 0.75 до 0.25 на $12.1 \%$;

- при одночасному збільшенні величини відносного прольоту зрізу та проценту поперечного армування балок першої та третьої серії на $3.3,4.5 \%$;

- при одночасному збільшенні величини відносного прольоту зрізу та зменшенні рівня попереднього напруження прогінних елементів обойми третьої серії на $6.1 \%$;

- при одночасному зменшенні класу бетону та попереднього напруження прогінних елементів обойми третьої серії на $6.8 \%$;

- при одночасному збільшенні проценту поперечного армування додатковою арматурою посилення та зменшенні попереднього напруження прогінних елементів обойми третьої серії на 4.5\%;

Стосовно першої та другої серії - наявність квадратичного ефекту при факторі зі знаком, протилежними прямому впливу вказаного чиннику, свідчіть про те, що за межами зміни дослідного фактору $\mathrm{a} / \mathrm{h}_{0}>3$ подальше збільшення $\mathrm{a} / \mathrm{h}_{0}$ не призведе до суттєвого підвищення прогину (перед руйнуванням). Що до третьої серії квадратичні ефекти при факторах та зі знаками, котрі не суперечать знакам основних факторів, свідчать про те, що за межами зміни дослідних факторів (a/h $>3, \mathrm{C}>40 / 50$ МПа) подальше збільшення $\mathrm{a} / \mathrm{h}_{0}$ призведе до суттєвого збільшення прогинів, а подальше збільшення класу бетону С має сенс, оскільки процес зниження $\mathrm{f}^{0.95 \mathrm{Fu}}$ ще не стабілізувався. Але цей висновок носить теоретичний характер, основні класи бетону, 3 котрих виготовлюються й виготовлялися згинані конструкції, були охопленні даним експериментальним дослідженням.

Перед руйнування прогини підсилених металевою попередньо-напруженою обоймою пошкоджених наскрізними похилими та нормальними тріщинами, залізобетонних балок збільшились у 2 рази в порівнянні зі статично навантаженими звичайними залізобетонними балками першої серії, й в 1,8 разів в порівнянні з балками з пошкодженнями другої серії. При цьому, слід відзначити, що несуча здатність пошкоджених у попередніх дослідженнях і підсилених попередньо напруженими металевими обоймами повторно випробуваних балок 
третьої серії перевищувала міцність дослідних зразків - балок, які до початку випробувань першої та другої серій не мали силових пошкоджень, відповідно, у 1,51 та в 1,85 разів.

Ширина розкриття нормальних тріщин в зоні "чистого згину" може бути представлена залежностями (7), (8):

$$
\begin{aligned}
\hat{Y}\left(\mathrm{~W}_{\mathrm{cr} 1,2}^{\perp \exp }\right)= & 0,14+0,02 \mathrm{X}_{1}+0,03 \mathrm{X}_{2}+0,01 \mathrm{X}_{3}+0,05 \mathrm{X}_{4}+0,01 \mathrm{X}_{1}^{2}-0,03 \mathrm{X}_{2}^{2} \\
& +0,02 \mathrm{X}_{4}^{2}+0,01 \mathrm{X}_{1} \mathrm{X}_{3}+0,01 \mathrm{X}_{1} \mathrm{X}_{4}+0,02 \mathrm{X}_{2} \mathrm{X}_{4}+0,01 \mathrm{X}_{3} \mathrm{X}_{4}, \mathrm{MM}, v=6,2 \% ; \\
\hat{\mathrm{Y}}\left(\mathrm{W}_{\mathrm{crf}}^{\operatorname{Lexp}}\right)= & 0,06+0,04 \mathrm{X}_{1}+0,02 \mathrm{X}_{2}+0,01 \mathrm{X}_{3}-0,01 \mathrm{X}_{4}+0,02 \mathrm{X}_{1} \mathrm{X}_{2}+0,02 \mathrm{X}_{1} \mathrm{X}_{3} \\
& -0,01 \mathrm{X}_{1} \mathrm{X}_{4}+0,01 \mathrm{X}_{2} \mathrm{X}_{3}, \mathrm{MM}, \quad \mathrm{v}=21,6 \% ;
\end{aligned}
$$

Ширина розкриття похилих тріщин на приопорних ділянках дослідних елементів може бути представлена експериментально-статистичними залежностями:

$$
\begin{aligned}
\hat{Y}\left(\mathrm{~W}_{\mathrm{cr} 1}^{\text {exp }}\right)= & 0,35-0,06 \mathrm{X}_{1}-0,03 \mathrm{X}_{2}-0,01 \mathrm{X}_{3}-0,14 \mathrm{X}_{4}-0,01 \mathrm{X}_{1} \mathrm{X}_{3}-0,03 \mathrm{X}_{2} \mathrm{X}_{4} & \\
& -0,02 \mathrm{X}_{3} \mathrm{X}_{4}, \mathrm{MM}, & \mathrm{v}=10,4 \% ; \\
\hat{\mathrm{Y}}\left(\mathrm{W}_{\mathrm{cr} 2}^{\text {exp }}\right)= & 0,63+0,05 \mathrm{X}_{1}+0,05 \mathrm{X}_{2}-0,06 \mathrm{X}_{3}+0,24 \mathrm{X}_{4}-0,02 \mathrm{X}_{2}^{2}+0,02 \mathrm{X}_{3}^{2} & \\
& +0,02 \mathrm{X}_{4}^{2}+0,11 \mathrm{X}_{1} \mathrm{X}_{2}-0,03 \mathrm{X}_{1} \mathrm{X}_{3}-0,06 \mathrm{X}_{3} \mathrm{X}_{4}, \mathrm{MM}, & \mathrm{v}=11,5 \% ; \\
\hat{\mathrm{Y}}\left(\mathrm{W}_{\mathrm{crf}}^{\text {exp }}\right)= & 0,50+0,20 \mathrm{X}_{1}-0,01 \mathrm{X}_{2}-0,05 \mathrm{X}_{3}-0,09 \mathrm{X}_{4}+0,03 \mathrm{X}_{1}^{2}-0,03 \mathrm{X}_{1} \mathrm{X}_{2} & \\
& -0,04 \mathrm{X}_{1} \mathrm{X}_{4}, \mathrm{MM}, & \mathrm{v}=8,4 \% ;
\end{aligned}
$$

Як видно, наявність металевої попередньо напруженої обойми стримує розвиток нормальних тріщин посередині балки і зменшує ширину їх розкриття, в середньому, в 2,3 рази. А ширина розкриття похилих тріщин у звичайних балках в 2,5 рази перевищує ширину розкриття нормальних тріщин в них при однократному статичному навантаженні. Дія малоциклового знакозмінного навантаження високих рівнів збільшує ширину розкриття похилих тріщин в них аж в 4,5 разів.

Ширина розкриття нормальних тріщин дослідних балок збільшується по відношенню до середніх їх значень для першої та другої серії 0,14 мм, для третьої серії 0,06 мм:

- при збільшенні відносного прольоту зрізу $\mathrm{a} / \mathrm{h}_{0}$ у першій, другій та третій серіях на 29 , 29 i $133 \%$;

- зі збільшенням класу бетону від С16/20 до С40/50, відповідно, на 43, 43 та 67\%;

- при збільшенні кількості поперечної металевої арматури $\rho_{\mathrm{sw}}$, в залізобетонних балках, першої та другої серій від 0,0016 до 0,0044 на 14\%;

- зі збільшенням процента поперечного армування додатковою арматурою посилення $\rho_{\mathrm{fw}}$ від 0,0046 до 0,0263 для третьої серії - на 33\%;

- при збільшенні рівня малоциклового знакозмінного навантаження $\eta$ від 0,5 до 0,8 для першої та другої серій - на 71\%;

- зі зменшенням рівня попереднього напруження в поздовжніх елементах обойми $\eta_{\sigma f}$ від 0,75 до 0,25 - на $33 \%$.

Ширина розкриття похилих тріщин залізобетонних балок збільшується по відношенню до середніх їх значень для першої, другої і третьої серії 0,35, 0,63, 0,5 мм, відповідно:

- зі зменшенням відносного прольоту зрізу а $/ \mathrm{h}_{0}$ у першій серії на $34 \%$;

- при збільшенні прольоту зрізу у другій та третій серіях на 16 і 80\%;

- зі зменшенням класу бетону від С40/50 до C16/20 у першій та третій серіях на 17 і 4\%;

- при збільшенні класу бетону у другій серії на 16\%;

- зі зменшенням кількості поперечної металевої арматури $\rho_{\mathrm{sw}}$, в залізобетонних балках першої та другої серій від 0,0044 до 0,0016 та проценту поперечного армування додатковою арматурою посилення $\rho_{\mathrm{fw}}$, третьої серії, від 0,0263 до 0,0046 на 6, 19 і 20\%;

- при збільшенні рівня малоциклового знакозмінного навантаження $\eta$ від 0,5 до 0,8 на $76 \%$

- зі зменшенням рівня попереднього напруження в прогінних елементах обойми $\eta_{\sigma f}$ від 0,75 до 0,25 на $36 \%$. 
Наявність квадратичного ефекту при факторі у першій та другій серіях для нормальних тріщин, а у другій серії для похилих тріщин зі знаком, протилежними прямому впливу вказаного чинника, свідчіть про те, що за межами зміни дослідного фактора С $>40 / 50$ МПа, подальше його збільшення не призведе до суттєвої зміни ширини розкриття тріщин. Та, навпаки, квадратичні ефекти при факторах у першій та другій серіях для нормальних тріщин, а у третій серії для похилих тріщин зі знаками, що не суперечать знакам основного впливу факторів свідчать про те, що за межами зміни дослідних факторів $\left(\mathrm{a} / \mathrm{h}_{0}>3, \rho_{\mathrm{sw}}>0,0044\right.$, $\eta>0,8)$ відбудеться збільшення ширини розкриття нормальних тріщин для першої та другої серії балок й подальший розвиток похилих тріщин у третій серії. Підвищуючи несучу здатність похилих перерізів за допомогою збільшення процента поперечного армування залізобетонних балок у другій серії ми досягаємо більшої ширини розкриття похилих тріщин. Підвищуючи рівень малоциклового знакозмінного навантаження $\eta>0,8$ для балок другої серії, отримаємо збільшення величини ширини розкриття нормальних та похилих тріщин.

Використання металевої попередньо напруженої обойми дозволило не тільки збільшити несучу здатність пошкоджених і розділених на окремі блоки дослідних балок в 1,85 разів, а й зменшити ширину розкриття похилих тріщин на $21 \%$, що являється ще одним свідченням переваги застосованого методу підсилення пошкоджених прогінних залізобетонних конструкцій.

Довжина проекції небезпечної похилої тріщини на горизонтальну вісь балки представлена виразами (12), (13):

$$
\begin{array}{cc}
\hat{Y}\left(1_{\text {crl }}^{/ \exp }\right)=201+53 X_{1}-19 X_{3}-4 X_{1} X_{2}-23 X_{1} X_{3}, \text { MM, } & v=8,5 \% ; \\
Y\left(l_{\text {cr } 2, \mathrm{f}}^{/ \exp }\right)=173+40 X_{1}-16 X_{3}+19 X_{4}+16 X_{1} X_{2}-7 X_{1} X_{3}+14 X_{1} X_{4}-11 X_{3} X_{4}, \text { MM, } & v=8,9 \% ;
\end{array}
$$

Як видно з (12) і (13), середня довжина проекції критичної похилої тріщини при малоцикловому знакозмінному навантаженні зменшується порівняно зі статичним одноразовим на $14 \%$ за рахунок втомного руйнування бетону стиснутої зони і руйнування захисного шару бетону на опорах.

Віддаль між нормальними тріщинами у зоні "чистого згину" характеризується залежностями (14), (15):

$$
\begin{array}{lc}
\hat{Y}\left(1_{\text {crl }}^{\perp \perp \exp }\right)=68-6 X_{1}+2 X_{2}+3 X_{1} X_{3}, \text { мм, } & v=5,1 \% ; \\
\hat{Y}\left(1_{\text {cr } 2 \mathrm{f}}^{\perp \perp \exp }\right)=70,9-2,15 X_{1}+1,93 X_{2}-1,75 X_{3}, \text { мМ, } & v=4,7 \% ;
\end{array}
$$

Висновки. 1. Експериментально доказана можливість та доцільність використання на практиці розробленого авторами роботи оригінального способу відновлення та підсилення пошкоджених наскрізними нормальними і перехресними похилими тріщинами, поділених ними на окремі блоки залізобетонних балкових конструкцій, за рахунок тристороннього обтиснення і пристрій для його здійснення, закріплений патентом на винахід [23], за дії зростаючого статичного, циклічного знакозмінного, сейсмічного, пульсуючого та іншого динамічного навантаження, в тому числі пошкоджених під час бойових дій за умови неповного їх руйнування зі збереженням початкової форми.

2. Реалізований системний підхід до експериментально-теоретичного вивчення напружено-деформованого стану звичайних, відновлених та підсилених пошкоджених наскрізними силовими тріщинами прогінних залізобетонних конструкцій за допомогою металевих попередньо напружених обойм, вперше дозволив зробити достовірну кількісну і якісну оцінку впливу конструктивних чинників та факторів зовнішньої дії на їх несучу здатність, жорсткість, тріщиностійкість та інші параметри працездатності як зокрема, так і у взаємодії один з одним, суттєво уточнити фізичну модель роботи вказаних конструкцій при ïx статичному та малоцикловому знакозмінному навантажені. 
3. Малоциклове повторне навантаження знижує несучу здатність приопорних ділянок звичайних залізобетонних балок, в середньому, на 8\% за [22], а малоциклове знакозмінне на $18 \%$.

4. Несуча здатність підсилених попередньо напруженими металевими обоймами [23] пошкоджених залізобетонних балок при знакозмінному навантаженні підвищилась, в середньому, на 51\% порівняно зі звичайними залізобетонними балками, випробуваними на одноразове статичне навантаження, що свідчить про високу ефективність такого підсилення.

5. Дія малоциклового знакозмінного навантаження збільшує прогини дослідних зразків-балок порівняно з одноразовим статичним ступенево зростаючим навантаженням на $20 \%$.

Застосування металевої попередньо напруженої обойми для підсилення пошкоджених балок збільшує як їхню несучу здатність, так і прогини в 1,85 разів при малоцикловому знакозмінному навантаженні порівняно з цими показниками в звичайних цільних балках при однократному навантаженні.

6. Ширина розкриття нормальних тріщин посередині дослідних балок всіх серій не перевищує допустимих величин і коливається в межах $0,02 \ldots 0,22$.

Середня величина розкриття похилих тріщин при експлуатаційних рівнях навантаження у дослідних елементах не перевищує допустимих значень, а перед руйнуванням - коливається в межах 0,35 ... 0,63 мм. При цьому, застосування металевої попередньо напруженої обойми зменшує ширину розкриття похилих тріщин, в середньому, на $21 \%$, а нормальних - в 2,3 рази.

7. Середня довжина горизонтальної проекції критичної похилої тріщини при малоцикловому знакозмінному навантаженні зменшується порівняно зі статичним одноразовим на 14\% за рахунок втомного руйнування стиснутої зони бетону і руйнування його захисного шару на опорах.

\section{Література}

1. Вплив циклічного знакозмінного та малоциклового навантаження на міцність залізобетонних балок / [В. М. Карпюк, К. І. Албу, Д. С. Даниленко та ін.]. // Віснік Одеської державної академії будівництва та архітектури. - 2015. - №58. - С. 103-119.

2. Azizov T. N. New design concepts for strengthening of continuous reinforced-concrete beams [Електронний ресурс] / T. N. Azizov, D. V. Kochkarev, T. A. Galinska // IOP Conference Series: Materials Science and Engineering. - 2019. - Режим доступу до ресурсу: https://iopscience.iop.org/article/10.1088/1757-899X/708/1/012040/pdf.

3. А. с. 1778250 СССР, МКИ3 Е 04 В 1/00. Способ усиления конструкций / Р. Х. Габузов, Э.П. Александрян (СССР). - №4776410/33; заявл. 03.01.90; опубл. 30.11.92, Бюл. №44.

4. Пинаджян В. В. К вопросу усиления изгибаемых конструкций / В. В. Пинаджян. // Известия Академии наук Армянской ССР. - 1947. - №9. - С. 79-108.

5. Онуфриев Н. М. Усиление железобетонных конструкций промышленных зданий и сооружений / Н. М. Онуфриев. - Ленинград: Стройиздат, 1965. - 342 с.

6. Мальганов А. И. Восстановление и усиление строительных конструкций аварийных и реконструируемых зданий. Атлас схем и чертежей / А. И. Мальганов, В. С. Плевков, А. И. Полищук. - Томск: Томский межотраслевой ЦНТИ, 1990. - 316 с.

7. А.c. 1481359 СССР, МКИ3 Е 04 G 23/02/ Конструкция усиления железобетонной балки / Е. А. Рабинович, В. Л. Благов, А. А. Бохотский (СССР). - № 4248550/29-33; заявл. 21.05.87; опубл. 23.05.89, Бюл. №19.

8. А.c. 1574771 СССР, МКИ3 Е 04 G 23/02/ Устройство для усиления изгибаемых строительных конструкций / А. П. Лука, Ф. С. Кравченя, А. Н. Соболь (СССР). - № 4302639/23-33; заявл. 08.09.87; опубл. 30.06.90, Бюл. № 24. 
9. Su R. K. Experimental and numerical studies of external steel plate strengthened reinforced concrete coupling beams / R. K. Su, Y. Zhu. // Engineering Structures. - 2005. - №27. - p. 15371550 .

10. $\mathrm{Su} \mathrm{R} . \mathrm{K}$. Effects of bolt-plate arrangements on steel plate strengthened reinforced concrete beams / R. K. Su, W. H. Siu, S. T. Smith. // Engineering Structures. - 2010. - №32. - p. $1769-1778$.

11. Aykaç S. Strengthening of reinforced concrete T-Beams with steel plates / S. Aykaç, E. Özbak. // Teknik Dergi/Technical Journal of Turkish Chamber of Civil Engineers. - 2011. - №22. p. 5319-5334.

12. Strengthening and repair of reinforced concrete beams using external steel plates / S.Aykaç, I. Kalkan, B. Aykaç, S. Karahan. // Journal of Structural Engineering (United States). 2013. - №139. - p. 929-939.

13. Савйовський В. В. Дослідження особливостей підсилення залізобетонних балкових конструкцій зовнішнім армуванням / В. В. Савйовський, О. С. Молодід // Вісник Придніпровської державної академії будівництва та архітектури. - 2017. - № 4. - С. 29-36.

14. Ozbek E. Strengthening of RC beams with solid steel plates / E. Ozbek, M. Bocek, S. Aykac. // Athens Journal of Technology \& Engineering. - 2016. - №3. - C. 291-298.

15. Performance of reinforced concrete beams retrofitted by a directShear anchorage retrofitting system / [H. Ying, P. Huawei, Q. Xueyou та ін.]. // Procedia Engineering. - 2017. №210. - p. 132-140.

16. Prevention of premature failures of plate bonded flexurally strengthened RC slab using end anchor and connector / A.Alam, W. Mohamed, S. Bakkar, S. Beddu. // Alexandria Engineering Journal. - 2018. - №51. - p. 287-299.

17. Чеканович М. Г. Підсилення залізобетонних балок зовнішньою стрижневокотковою системою / М. Г. Чеканович, В. П. Журахівський, О. М. Чеканович. // Ресурсоекономічні матеріали, конструкції та споруди : зб. наук. праць. - 2018. - №36. - С. 413-420.

18. Development of the procedure for the estimation of reliability of reinforced concrete beams, strengthened by building up the stretched reinforcing bars under load / R.Khmil, R. Tytarenko, Y. Blikharskyy, P. Vegera. // Eastern-European Journal of Enterprise Technologies. 2018. - №7. - p. 32-42.

19. Influence of load level during strengthening of reinforced concrete beams on their reliability [Електронний ресурс] / R.Khmil, R. Tytarenko, Y. Blikharskyy, R. Vashkevych // IOP Conference Series: Materials Science and Engineering. - 2019. - Режим доступу до ресурсу: https://iopscience.iop.org/article/10.1088/1757-899X/708/1/012054/pdf.

20. Karpiuk V. Calculation models of the bearing capacity of span reinforced concrete structure support zones, / V. Karpiuk, Y. Somina, D. Antonova. // MSF.- 2019. - №968.

21. Karpiuk V. Engineering Method of Calculation of Beam Structures Inclined Sections Based on the Fatigue Fracture Model / V. Karpiuk, Y. Somina, O. Maistrenko. - 2020. - №47. - p. $135-144$.

22. Особливості напруженно-деформованого стану i розрахунку залізобетонних конструкцій за дії циклічного навантаження високих рівнів: монографія / В. М.Карпюк, Ю. А. Сьоміна, А. І. Костюк, О. Ф. Майстренко. - Одеса: ОДАБА, 2018. - 237 с.

23. Спосіб відновлення та підсилення пошкоджених залізобетонних балок і пристрій для його здійснення : пат. 119294 Україна : МПК Е04В 1/18, E04B 1/20, E04BG 23/02.№ a 201800651 ; заявл. 23.01.2018; опубл. 27.05.2019, Бюл. №10

24. Вознесенский В. А. Статистические методы планирования эксперемента в техникоэкономических исследованиях / В. А. Вознесенский. - Москва: Финансы и статистика, 1981. $-215 \mathrm{c}$.

25. Залесов А. С. Прочность железобетонных конструкций при действии поперечных сил / А. С. Залесов, Ю. А. Климов. - Киев: Будівельник, 1989. - 104 с. 


\section{References}

[1] V.M. Karpiuk, K.I. Albu, D.S. Danilenko, Y.A. Somina, „Vplyv cyklichnogo znakozminnogo ta malocyklovogo navantazhennya na micznist' zalizobetonnyx balok", Visnyk ODABA, Odesa, Optimym, vol. 58, pp. 103-119, 2015.

[2] T. N. Azizov, D. V. Kochkarev, T. A. Galinska, "New design concepts for strengthening of continuous reinforced-concrete beams", IOP Conference Series: Materials Science and Engineering, [Elektronnyy resurs]. Rezhym dostupu: http://www.pu.if.ua/inst/phys_che/start/pcss/vol14/1402-03.pdf. Accessed on: May 12, 2020.

[3] R. Gabuzov, E. Aleksandryan, "Sposob usileniya konstrukcij", MKI ${ }^{3}$ E 04 V 1/00. №4776410/33, Nov. 30, 1992.

[4] V.V. Pinadzhyan, "K voprosu usileniya izgibaemyh konstrukcij”, In: Izvestiya Akademii nauk Armyanskoj SSR, №9, pp. 79-108, 1947.

[5] N.M. Onufriev, 'Usilenie zhelezobetonnyh konstrukcij promyshlennyh zdanij i sooruzhenij”, Leningrad: Strojizdat, 1965.

[6] A.I. Malganov, V.S. Plevkov, A.I. Polishuk, "Vosstanovlenie i usilenie stroitel'nyh konstrukcij avarijnyh i rekonstruiruemyh zdanij. Atlas skhem i chertezhej", Tomsk, Tomskij mezhotraslevoj CNTI, 1990.

[7] E. Rabinovich, V. Blagov, A. Bohotskij, "Konstrukciya usileniya zhelezobetonnoj balki", MKI3 E 04 G 23/02. № 4248550/29-33, May 23, 1989.

[8] A. Luka, F. Kravchenya, A. Sobol, "Ustrojstvo dlya usileniya izgibaemyh stroitel'nyh konstrukcij”, MKI3 E 04 G 23/02. № 4302639/23-33, Jun 30, 1990.

[9] R. Su, "Experimental and numerical studies of external steel plate strengthened reinforced concrete coupling beams", In: Engineering Structures, no. 27, pp. 1537-1550, 2005.

[10] R. Su, "Effects of bolt-plate arrangements on steel plate strengthened reinforced concrete beams", In: Engineering Structures, no. 32, pp. 1769-1778, 2010.

[11] S. Aykac, "Strengthening of reinforced concrete T-Beams with steel plates", In: Teknik Dergi/Technical Journal of Turkish Chamber of Civil Engineers, no. 22, pp. 5319-5334, 2011.

[12] S. Aykac, I. Kalkan, B. Aykac, S. "Karahan, Strengthening and repair of reinforced concrete beams using external steel plates", In: Journal of Structural Engineering, United States, no. 139, pp. 929-939, 2013.

[13] V.V. Savjovskij, O.S. Molodid, "Doslidzhennya osoblivostej pidsilennya zalizobetonnih balkovih konstrukcij zovnishnim armuvannyam", In: Visnik Pridniprovs'koï derzhavnoï akademiï budivnictva ta arhitekturi, no. 4, pp. 29-36, 2017.

[14] E. Ozbek, M. Bocek, S. Aykac, "Strengthening of RC beams with solid steel plates", In: Athens Journal of Technology \& Engineering, no. 3, pp. 291-298, 2016.

[15] H. Ying, P. Huawei, Q. Xueyou, P. Jun, L. Xiancun, P. Qiyun, L. Bao, "Performance of reinforced concrete beams retrofitted by a direct shear anchorage retrofitting system", In: Procedia Engineering, no. 210, pp. 132-140, 2017.

[16] A. Alam, W. Mohamed, S. Bakkar, S. Beddu, "Prevention of premature failures of plate bonded flexurally strengthened RC slab using end anchor and connector", In: Alexandria Engineering Journal, no. 51, pp. 287-299, 2018.

[17] M.G. Chekanovich, V.P. Zhurahivskij, O.M. Chekanovich, "Pidsilennya zalizobetonnih balok zovnishn'oyu strizhnevo-kotkovoyu sistemoyu", In: Resursoekonomichni materiali, konstrukciï ta sporudi : zbirnik naukovih prac', no. 36, pp. 413-420, 2018.

[18] R. Khmil, R. Tytarenko, Y. Blikharskyy, P. Vegera, "Development of the procedure for the estimation of reliability of reinforced concrete beams, strengthened by building up the stretched reinforcing bars under load", In: Eastern-European Journal of Enterprise Technologies, no. 7, pp. 32-42, 2018. 
[19] R. Khmil, R. Tytarenko, Y. Blikharskyy, Y. Vashkevych, "Influence of load level during strengthening of reinforced concrete beams on their reliability" [online]. [accesat 10.05.2020]. Disponibil: https://iopscience.iop.org/article/10.1088/1757-899X/708/1/012054/pdf.

[20] V. Karpiuk, Y. Somina, D. Antonova, "Calculation models of the bearing capacity of span reinforced concrete structure support zones", no. 968, MSF, 2019.

[21] V. Karpiuk, Y. Somina, O. Maistrenko, "Engineering Method of Calculation of Beam Structures Inclined Sections Based on the Fatigue Fracture Model", no. 47, p.135-144, 2020.

[22] V. Karpiuk, Y. Somina, A. Kostyuk, O. Maistrenko, "Osoblivosti napruzhennodeformovanogo stanu i rozrahunku zalizobetonnih konstrukcij za diï ciklichnogo navantazhennya visokih rivniv: monografiya", Odessa: OSACEA, 2018.

[23] V.M. Karpiuk, D.S. Danilenko, I.A. Karpiuk, A.V. Danilenko, "Sposib vidnovlennya ta pidsilennya poshkodzhenih zalizobetonnih balok i pristrij dlya jogo zdijsnennya", MPK E04B 1/18, E04B 1/20, E04G 23/02. № a 2018 00651, May 27, 2019.

[24] V. Voznesenskij, "Statisticheskie metody planirovaniya eksperementa v tekhnikoekonomicheskih issledovaniyah", Moscow: Finance and Statistics, 1981.

[25] A. Zalesov, Y. Klimov, "Prochnost' zhelezobetonnyh konstrukcij pri dejstvii poperechnyh sil", Kiev: Budivel'nik, 1989.

\section{ФИЗИЧЕСКАЯ МОДЕЛЬ РАБОТИ СИСТЕМЫ «МЕТАЛЛИЧЕСКАЯ ПРЕДВАРИТЕЛЬНО НАПРЯЖЕННАЯ ОБОЙМА УСИЛЕНИЯ - ПОВРЕЖДЕННАЯ ЖЕЛЕЗОБЕТОННАЯ БАЛКА»}

Карпюк В. М., д.т.н., профессор, Даниленко Д.С., аспирант, Карпюк И.А., к.т.н., доцент, Даниленко А.В., к.т.н., ассистент, Семина Ю.А., к.Т.Н., асистент, Одесская государственная академия строительства и архитектуры

Аннотация. Анализ повреждений, ответственных за жизнедеятельность пролетной железобетонной конструкции, сооружения или здания, в целом показал, что в процессе их эксплуатации происходит значительное разрушение защитного слоя бетона, коррозия арматуры, образование и чрезмерное раскрытие трещин, достижение недопустимых прогибов и т.П..

Цель данной работы заключается в экспериментально-теоретическом исследовании физической модели работы усиленных предварительно напряженными металлическими обоймами поврежденных сквозными нормальными и перекрестными наклонными трещинами железобетонных балок при действии малоцикловой знакопеременной нагрузки высоких уровней.

Для этого авторами был создан способ для восстановления и усиления поврежденных железобетонных балок, находящихся в предаварийном состоянии в результате действия знакопеременной циклической или пульсирующей нагрузки высоких уровней, и устройство для его осуществления. Все опытные образцы-балки были изготовлены и испытаны согласно теории планирования эксперимента по Д-оптимальным планом Бокса В4.

Реализован системный подход к экспериментально-теоретическому изучению напряженно-деформированного состояния обычных, восстановленных и усиленных поврежденных сквозными силовыми трещинами пролетных железобетонных конструкций с помощью металлических предварительно напряженных обойм впервые позволил сделать достоверную количественную и качественную оценку влияния конструктивных факторов и факторов внешнего воздействия на их физическую модель работы указанных конструкций при статическом и малоцикловом знакопеременном нагружении. 
Экспериментально доказана возможность и целесообразность использования на практике предложенного авторами работы оригинального способа и устройства восстановления и усиления поврежденных сквозными нормальными и перекрестными наклонными трещинами, разделенных ими на отдельные блоки, железобетонных балочных конструкций за счет трехстороннего обжатия при действии растущей статической, циклической знакопеременной, сейсмической, пульсирующей или иной динамической нагрузки при неполном их разрушении с сохранением первоначальной формы.

Ключевые слова: поврежденная силовыми трещинами железобетонная балка, металлическая предварительно напряженная обойма, малоцикловая знакопеременная нагрузка.

\title{
PHYSICAL MODEL OF WORK OF THE SYSTEM «METAL PRELIMINARY TENSION REINFORCEMENT JACKET - DAMAGED REINFORCED CONCRETE BEAM»
}

\author{
Karpiuk V.M., ScD, Professor, \\ Danilenko D.S., post-graduate student, \\ Karpiuk I.A., $\mathrm{PhD}$, Associate Professor, \\ Danilenko A.V., PhD, Assistant, \\ Somina Yu.A., PhD, Assistant, \\ Odessa State Academy of Civil Engineering and Architecture
}

\begin{abstract}
Analysis of the damage responsible for the vital activity of a span reinforced concrete structure, structure or building, in general, showed that during their operation there is a significant destruction of the concrete protective layer, corrosion of the reinforcement, crack formation and excessive opening, achievement of unacceptable deflections, etc.

The aim of this work is to experimentally and theoretically study physical models reinforced with prestressed metal jackets damaged by through normal and transverse-inclined cracks in reinforced concrete beams under active low-cycle alternating loads of high levels.

To this end, a method was created for the restoration of damaged reinforced concrete beams needed in an anticipated state, as a result of which alternating cyclic or pulsating loads of high levels arise, and a device for providing it. All tested beam samples were manufactured and tested in accordance with the experimental design theory and D-optimum plan of Box B4.

The accomplished system approach to the experimental and theoretical research of the stressstrain behaviour of the common, renewed and strengthened reinforced concrete span structures damaged with through forced cracks with the aid of metal prestressed metal casings enabled to make a reliable quantitative and qualitative evaluation of the design factors and external factors impact on their load-bearing capacity, stiffness, crack resistance and other performance parameters, either individually or in their interaction with each other, considerably specify the physical model of said structures performance when subjected to static and low-cycle alternate loading.

The experiments have proved a possibility and expediency of practical application of the ingenious method developed by the authors which is distinctive of renewal and strengthening of the damaged reinforced concrete beam structures damaged with through normal and cross inclined cracks which divide the beam into separate blocks due to three-side clamping, and the arrangement for its accomplishment claimed by the patent of invention subjected to action of the increasing static, cyclic, alternate, seismic, fluctuating and other dynamic loading, including, among other things, the reinforced concrete beams damaged during military activity provide such beams did not collapse completely and preserve their initial shape.

Keywords: damaged reinforced concrete beam, prestressed metal casings, low-cycle alternate loading.
\end{abstract}




\title{
ПРОСТОРОВА ТРАНСФОРМАЦІЯ КОНСТРУКТИВНИХ ЕЛЕМЕНТІВ СУЧАСНИХ ОБОЛОНОК ПОКРИТЬ
}

\author{
Коломійчук Г.П., к.т.н., доцент, \\ gp11k1m@gmail.com, ORCID: 0000-0003-4484-7791 \\ Коломійчук В.Г., студентка, \\ veronika.kolomy@gmail.com \\ Одеська державна академія будівництва та архітектури
}

\begin{abstract}
Анотація. Розглянуто конструкції що змінюють свої геометричні розміри, тобто трансформуються під час експлуатації, для вирішення завдань по створенню належного мікроклімату в середині будівель та споруд. В дослідженні виділено тільки просторові конструкції що складаються 3 елементів нелінійного переміщення у просторі. Наведені сучасні способи трансформації конструкцій, що отримали найбільш високу оцінку під час експлуатації, і $\epsilon$ перспективним для подальшого дослідження та розвитку. Для прикладів використані конструкції експлуатація і будівництво яких контролюється за допомогою комп’ютерних програм. На основі аналізу зведених за допомогою трансформації оболонок різної форми отримані математичні моделі для визначення їх оптимальних габаритних розмірів і можуть бути використані в проектуванні нових оболонок.
\end{abstract}

Ключові слова: просторова трансформація оболонок, розумні конструкції, адаптивна архітектура, оптимальні розміри оболонок, реконструкція.

Вступ. Трансформовані просторові конструкції будівель та споруд - складова частина сучасної адаптивної архітектури, що сприймає нові вимоги суспільства та пристосовує їх в будівлях та спорудах. Потреба в динамічній адаптації архітектурних об'єктів обумовлена необхідністю усунення протиріччя між постійно зростаючими і мінливими потребами людей i незмінюваністю характеристик середовища [1]. Проектування трансформованих просторових конструкції сприяє зменшенню негативного впливу будівель та споруд на навколишне середовище, скороченню витрат на енергоспоживання, що безперечно сприятиме сталому розвитку міського середовища. Розвиток трансформації конструкцій в першу чергу пов'язаний з впровадженням інформаційно-комп'ютерних технологій.

Аналіз останніх досліджень та публікацій. Особливе місце серед великогабаритних трансформованих космічних систем займають просторові конструкції, розкриття яких відбувається автоматично при спрацьовуванні запобіжного механізму за рахунок початкової накопиченої енергії пружин, розташованих в шарнірних з'єднаннях [2]. Вони складаються 3 двох поясів, з'єднаних між собою діагональними стрижнями. На рис. 1 наведено рефлектор антени просторової конструкції в розкритому стані.

Стрижні просторової конструкції можуть бути виконані як 3 металу, так i 3 композиційного матеріалу. На рис. 2 показано конструкції вузлового шарніру і шарніру в стрижні що здатний складатися.

Розвиток способу розгортання великогабаритних конструкцій передбачає застосування автоматичних систем в яких для розкриття використовується електрична енергія. Автоматичні актуатори дають можливість керувати процесом розкриття, зменшують коливання та прогини конструкції.

В огляді [3] наведено великопролітні конструкції покрить що трансформуються. Розглянуті конструкції монтаж яких виконувався за способом «Pantadome System», а також існуючі великопролітні покриття 3 простою трансформацію.

Застосування трансформації в архітектурі сучасних унікальних суспільних будівель та споруд в яких закладені біонічні підходи розглянуті в $[4,5]$. Використання трансформації в архітектурі будівель та споруд збільшує їх багатофункціональність та дозволяє створювати унікальні форми та конструктивні рішення. 


\section{Стрижні верхнього поясу}
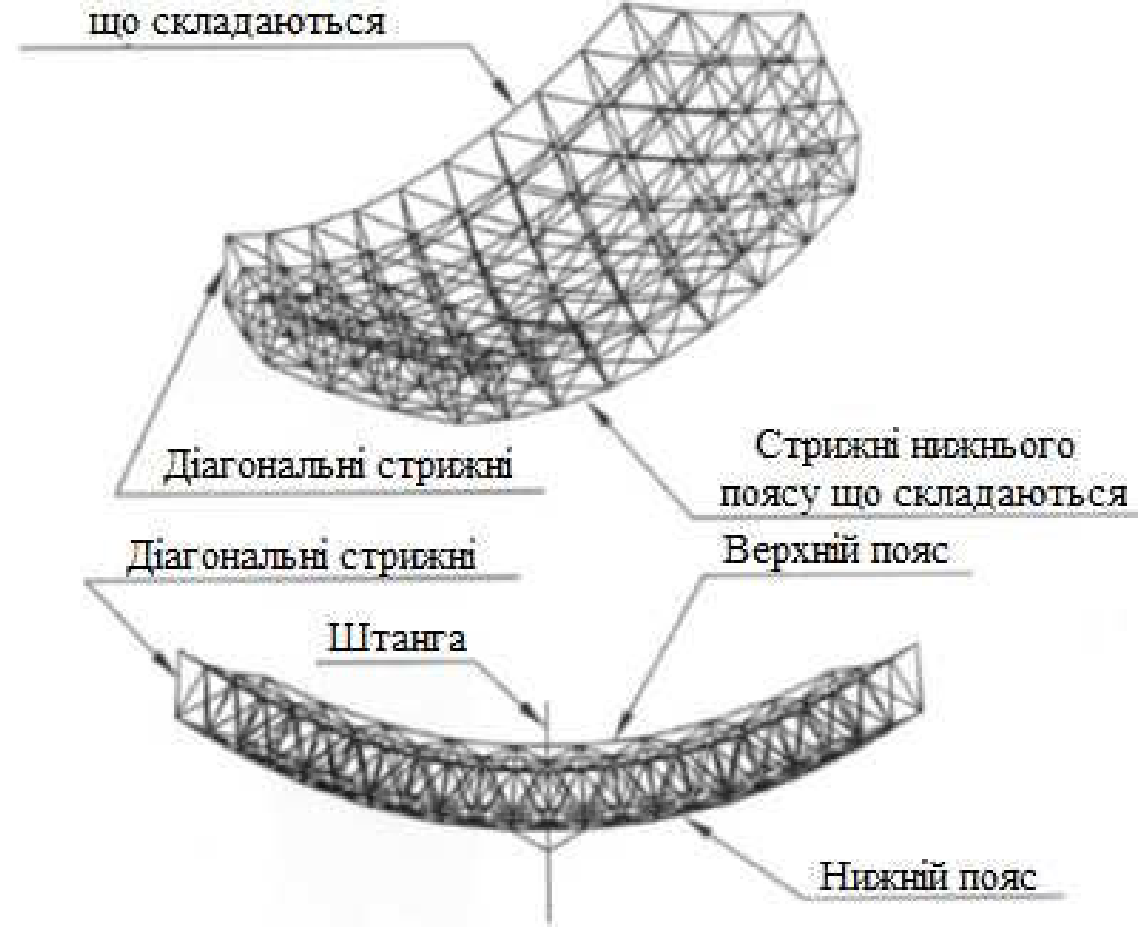

Рис.1. Просторова конструкція рефлектора антени

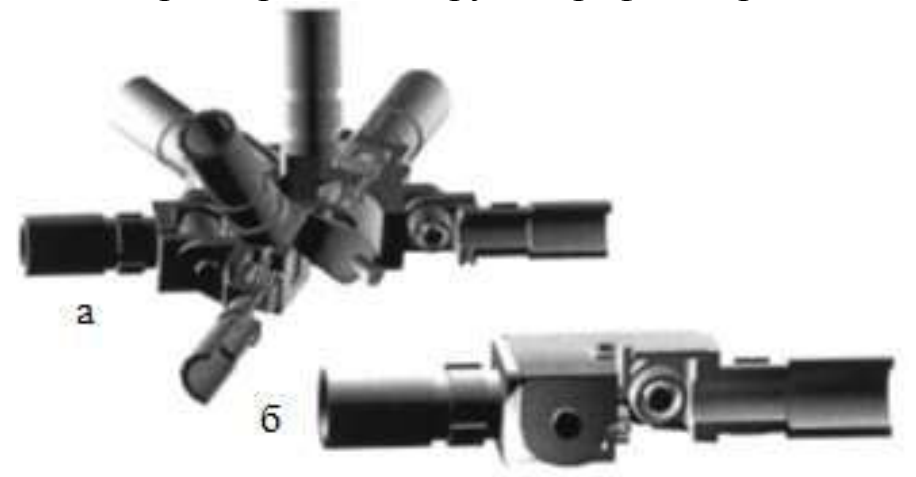

Рис.2. Вузлові шарніри, що з'єднують діагональні стрижні зі стрижнями що складаються верхнього і нижнього поясів (а), шарнір, що з'єднує елементи стрижня що складається (б)

В науковій роботі [6] розроблено нові концепцій по розкриттю конструкцій що використовуються в мобільних будівлях та спорудах. Починаючи з вибору необхідної геометрії на основі архітектурно релевантних параметрів, оцінюючи кінематику конструктивної системи та виконуючи дослідження техніко-економічного обгрунтування, продемонстровано повний процес проектування, що розкриває сильні та слабкі сторони конструкцій що трансформуються.

Незважаючи на велику кількість існуючих просторових покрить що трансформуються в них використовується проста трансформація, а запропоновані вражаючі моделі 3 просторовою трансформацією, через механічну складність їх систем під час процесу складання і розгортання, не побудовані в натуральну величину.

Мета та завдання. Метою даного дослідження $є$ вибір раціональних конструктивних рішень сучасних оболонок покрить що просторово трансформуються, їх аналіз та розробка математичних моделей що дозволяють отримувати оптимальні розміри для проектування.

На відміну від подібних досліджень інших авторів, де здебільшого виконувався архітектурний огляд трансформації оболонок, в даній роботі виконано огляд конструктивних рішень складної трансформації оболонок.

Завдання дослідження: виконати аналіз розвитку сучасних конструктивних рішень просторової трансформації оболонок; виявити оболонкові покриття різної форми побудовані 
за допомогою трансформації; отримати математичні моделі що допомагають визначати оптимальні розміри оболонок, побудованих за допомогою трансформації, та використовувати в проектуванні нових конструкцій.

Матеріали та методика дослідження. Трансформовані просторові конструкції складова частина унікальних будівель та споруд. Найчастіше просторова трансформація використовується для підйому оболонок покриття в проектне положення та при експлуатації під час розкриття частини, або всієї оболонки покриття.

В силу малої кількості однотипних конструктивних рішень оболонок покрить 3 просторовою трансформацією для аналізу вибрані лише ті що отримали найбільш високу оцінку під час експлуатації, і є перспективними для подальшого дослідження та розвитку.

Результати досліджень. Розширюючи роботу над двовимірними конструкціями висувних пластин, в науковій роботі [7] запропоновано елегантне рішення для просторових висувних купольних конструкцій, використовуючи тільки фрагменти оболонок замість комбінації багатокутних елементів і накладок. Однією з пропозицій автора є новий тип куполу що трансформується. Існуюча просторова конструкція не має будь-яких перекриттів, i, отже, усувається тертя між сусідніми оболонковими елементами, що робить ії більш придатною для великопролітних застосувань. Іншими перевагами конструкції куполу $є$ можливість зміни меж оболонкових елементів і розташування нерухомих точок, навколо яких вони обертаються. На рис. 3 показаний купол що трансформується 3 симетрично розташованими оболонковими елементами, що мають фіксовані точки обертання. Елементи оболонки забезпечують вільну поверхню у відкритому і закритому положенні.

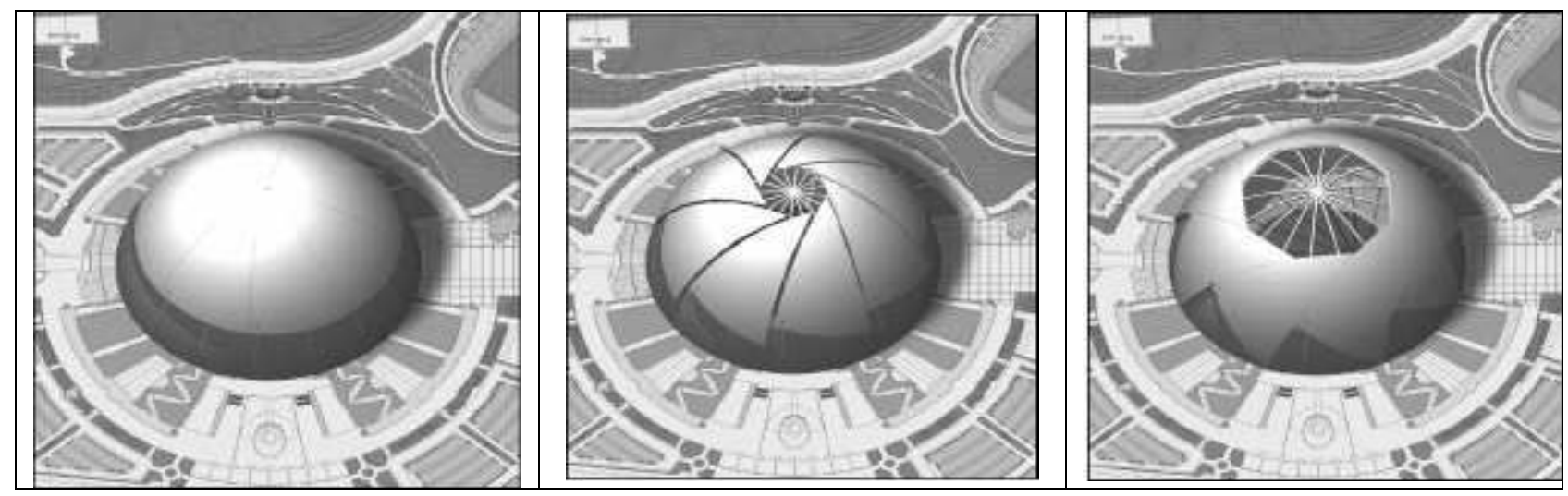

Рис.3. Купол з оболонкових елементів 3 фіксованими точками обертання: а) закритий стан покриття; б) 8 оболонкових елементів в проміжному стані; в) розкритий стан покриття

Проте, в найближчому майбутньому в будівництві, необхідно зробити так, щоб конструкція мала живий рух, гнучкість i, крім того, інтелект. Зокрема, конструкція змінюється в форму, гармонізовану з навколишнім середовищем, і зміна форми реалізує більш універсальну функцію. В одному з механізмів, які роблять можливим більш складний pyx, є просторова ферма зі змінною геометрією, яка названа VGT (Variable Geometry Truss ферма змінної геометріï) [8]. Спочатку конструкція VGT була розроблена в якості робочого механізму космічного апарату і була доповнена невеликим двигуном для виконання різних завдань в космічному просторі.

Як показано на рис. 4,a, VGT - це просторова конструкція, яка складається з пружних елементів і шарнірів. Контролюючи довжину пружних елементів, можна створити різні форми просторової конструкції. Приклад зміни форми, що поєднує два розміри VGT послідовно, показаний на рис. 4,б. Під час розтягування одного пружного елементу VGT кожні два промені що з'єднані з ним змінюється у нову форму, коли він рухається. Розтягуючи пружні елементи разом, конструкція змінюється, як пружина. Переміщення елементів VGT виконується за допомогою гідравлічних домкратів, дії яких і в свою чергу контролюються комп'ютерною програмою. 


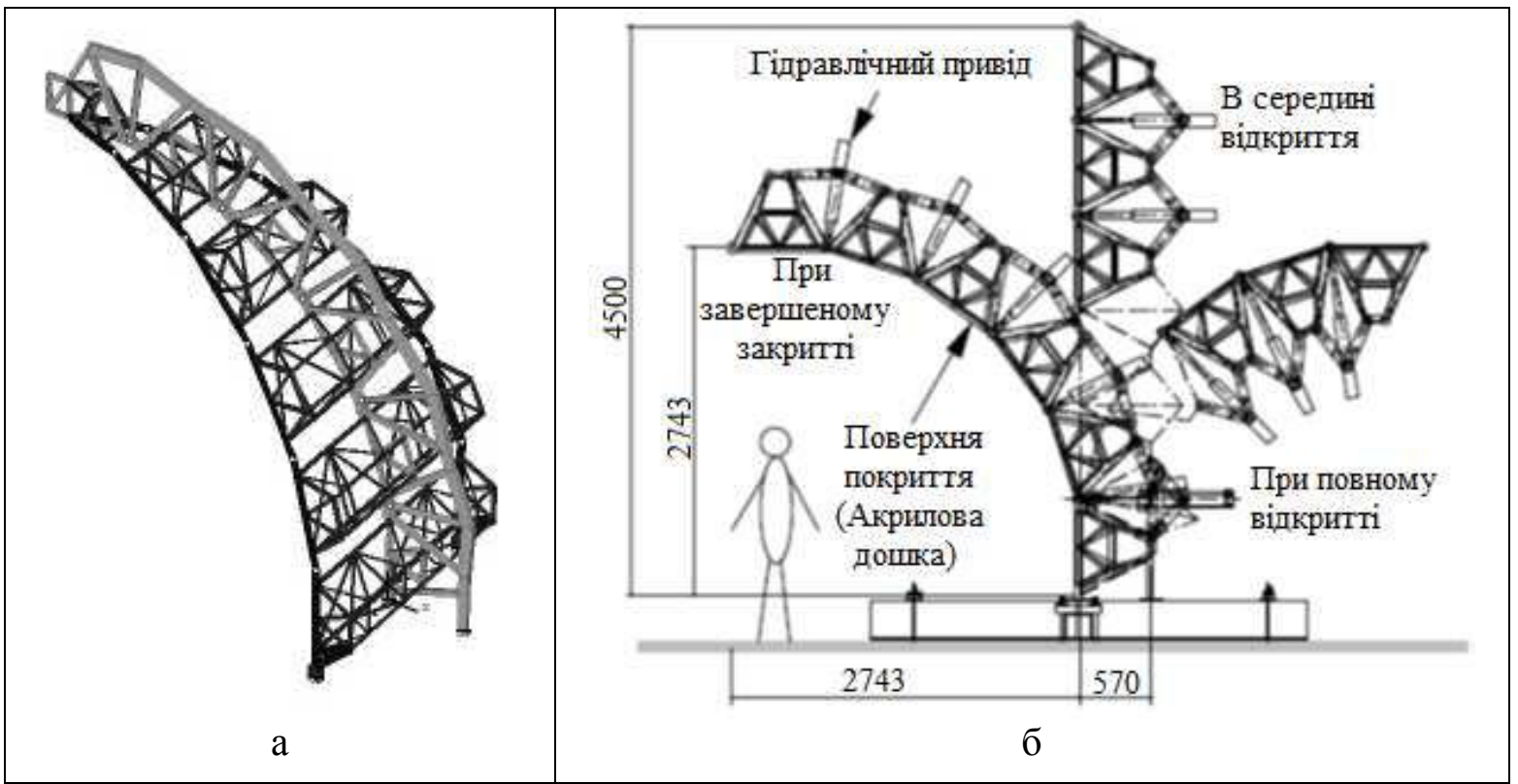

Рис. 4. Просторова конструкція ферми змінної геометрії: а) елемент VGT в закритому стані; б) граничні положення елементу VGT в закритому та розкритому станах

На рис. 5 наведено авторську розробку [8] купольного покриття що трансформується за складною траєкторією, утвореного з 10 ферм змінної геометрії.

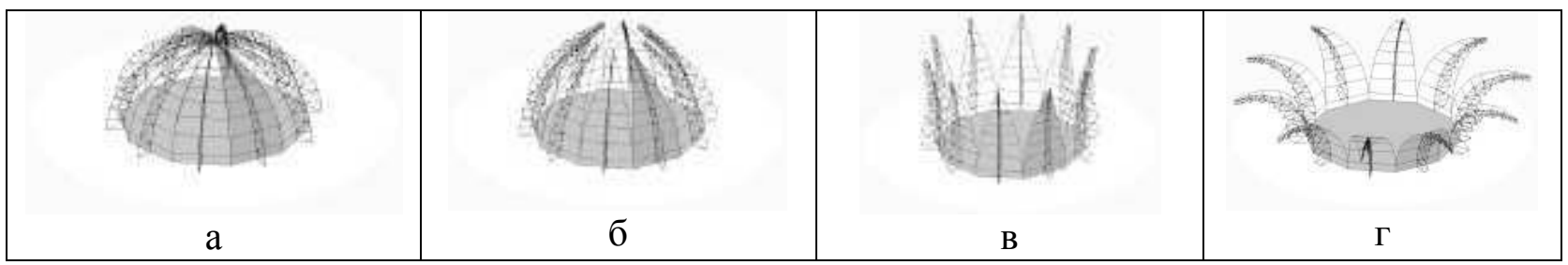

Рис. 5. Моделювання закриття та розкриття куполу: а) закритий стан; б) напівзакритий стан; в) розкритий стан з вертикальним положенням елементів VGT; г) граничний розкритий стан

Професор М. Кавагучі [9] розробив систему під назвою «Pantadome System», яка використовується для створення просторових покриттів, що трансформуються в процесі зведення. Основний принцип «Pantadome System» полягає в тому, що просторова конструкція перетворюється в геометрично змінну тільки на період іï зведення. Це досягається тим, що окремі елементи, на які розділена оболонка, з'єднуються між собою тимчасовими конструктивними шарнірами. Збірка елементів проводиться на рівні землі. Кількість шарнірів призначається мінімальною для того, щоб конструкцію можна було підняти за меншу кількість точок i, в той же час, в процесі підйому окремі елементи оболонки могли вільно повертатися, утворюючи механізм. На рис. 6 показано приклад підйому трансформованого покриття у вигляді сітчастого металевого куполу, розділеного на окремі елементи трьома кільцевих лініями шарнірів. Розташувавши «складену» конструкцію, як показано на рис. 6, а, і встановивши домкрати в точках 3 шарнірами №1, можна підняти купол в проектне положення (рис. 6, в).

У 1996 році в місті Кадома префектури Осака побудований універсальний спортивний центр з залом в формі овалу. Габаритні розміри: - довжина 127 м; - ширина 110 м; - висота 42 м. Покриття будівлі являє собою двопоясну сітчасту металеву оболонку висотою 1,5 м 3 невеликим нахилом по довжині що складає $5^{\circ}$. Унікальність універсального спортивного центру в тому, що просторова конструкція його покриття, трансформована в процесі підйому за принципами «Pantadome System». Перед підйомом оболонка покриття була розділена по периметру трьома лініями тимчасових конструктивних шарнірів, за допомогою яких вона 
являла собою механізм (кінематично змінну конструкцію), як показано на рис. 7. Сітчаста металева оболонка розділена на три частини (монтажні блоки): центральну, середню і нижню

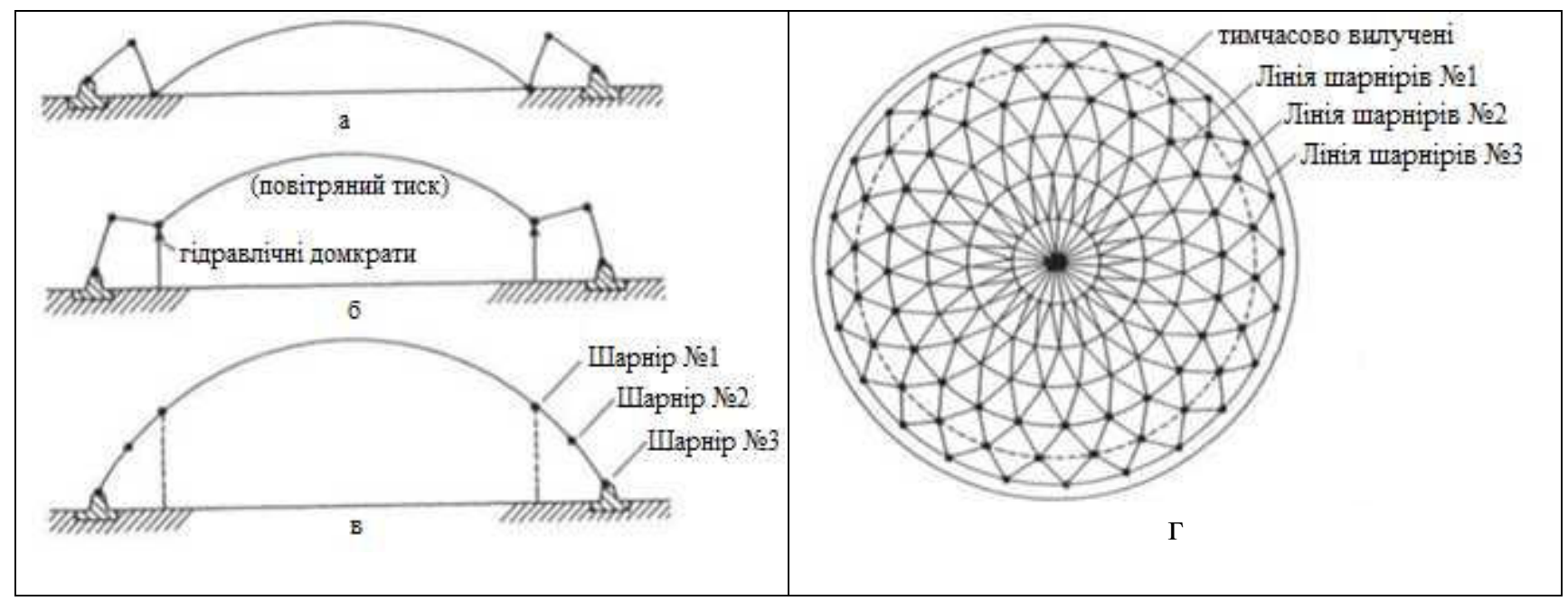

Рис. 6. Підйом сітчастого металевого куполу: а) складена конструкція перед підйомом; б) проміжний стан підйому; в) конструкція в проектному положенні; розміщення тимчасових шарнірів на плані покриття

(опорну). Найбільша центральна частина, з розмірами в плані 86х66 м, з'єднана тимчасовими шарнірами №1 3 середньою частиною. Середня і нижня частини, в свою чергу, розділені лініями шарнірів №2 на 14 монтажних блоків.

Центральна частина оболонки покриття зібрана на риштованні на невеликій відстані від поверхні землі. Блоки нижньої частини покриття опиралися (в місцях шарнірів №3) на залізобетонну кільцеву оболонку, верхня площина якої нахилена до горизонту на $5^{\circ}$. Підйом металевої оболонки покриття в проектне положення здійснювався 16 гідравлічними домкратами, розташованими по периметру центрального монтажного блоку, і з'єднаними 3 ними висувними монтажними стійками (рис. 7). За допомогою домкратів оболонка покриття піднята в проектне положення на висоту 28,74 м, після чого виконана заміна тимчасових шарнірів жорсткими зв'язками і жорстке з'єднання між собою окремих блоків по лініях перерізів. Весь процес підйому покриття проводився під контролем спеціальної комп'ютерної програми.

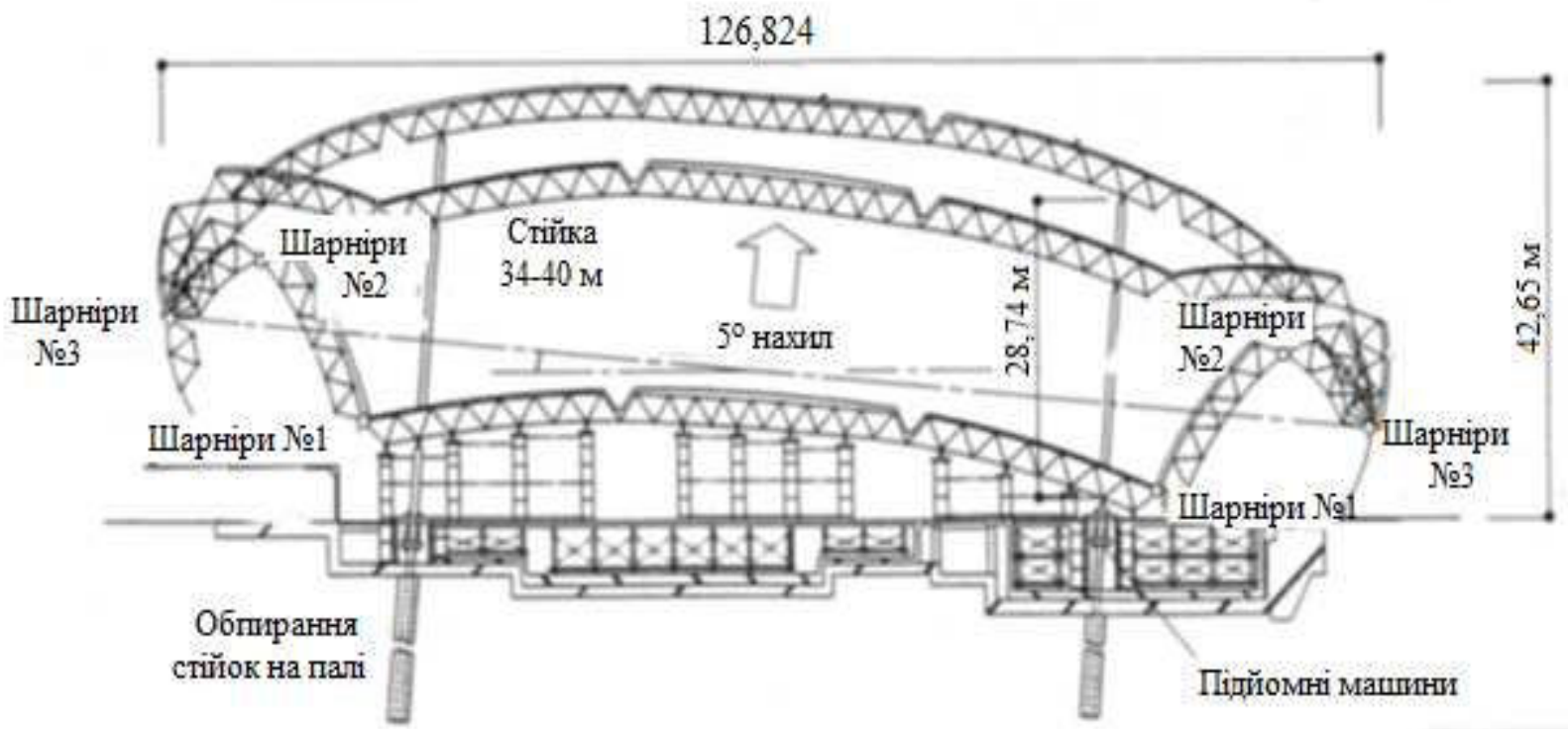

Рис. 7. Етапи зведення металевої сітчастої оболонки за принципами «Pantadome System» 
В Хатіві (Іспанія) виконано реконструкцію арени для бою биків 3 влаштуванням покриття над трибунами у вигляді металевого куполу [10]. Оболонка покриття зведена за допомогою нового способу «Pantadome System». Купол сферичної форми 3 центральним отвором діаметром 42 м і зовнішнім діаметром 101,6 м, опертий на 44 колони, розподілених по колу діаметром 86,4 м. Несуча конструкція покриття утворена гратами радіальних ферм, прикріплених до колон і внутрішнього кільця. Вона підтримується дією зовнішнього натяжного кільця, за допомогою елементів радіального натягу, а також розтягуванням (верхній пояс) та стисненням (нижній пояс) у внутрішньому кільці. Конструкція покриття зібрана на поверхні землі (рис. 8 а, б) і піднята в проектне положення шляхом укорочення 44 радіальних канатів 3 домкратами, прикріплених до внутрішнього кільця. Весь процес підйому покриття проводився під контролем спеціальної комп'ютерної програми.

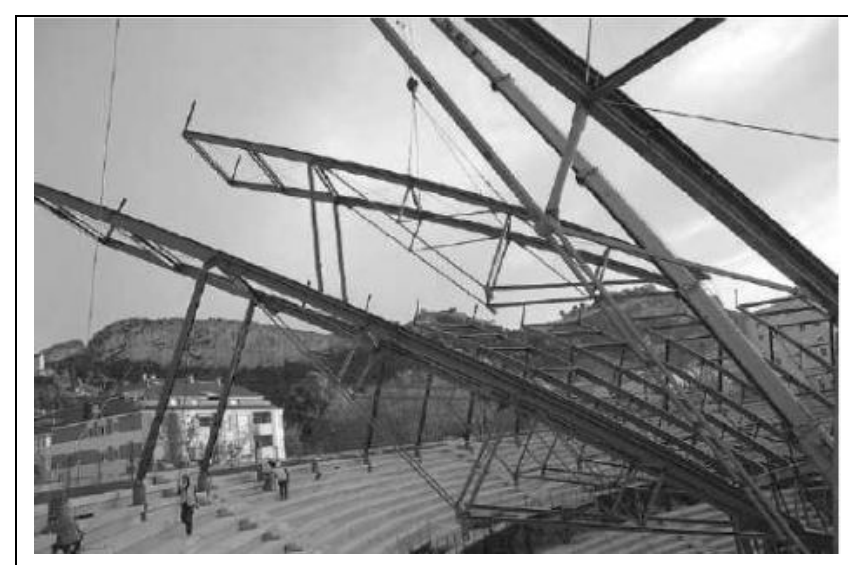

$\mathrm{a}$

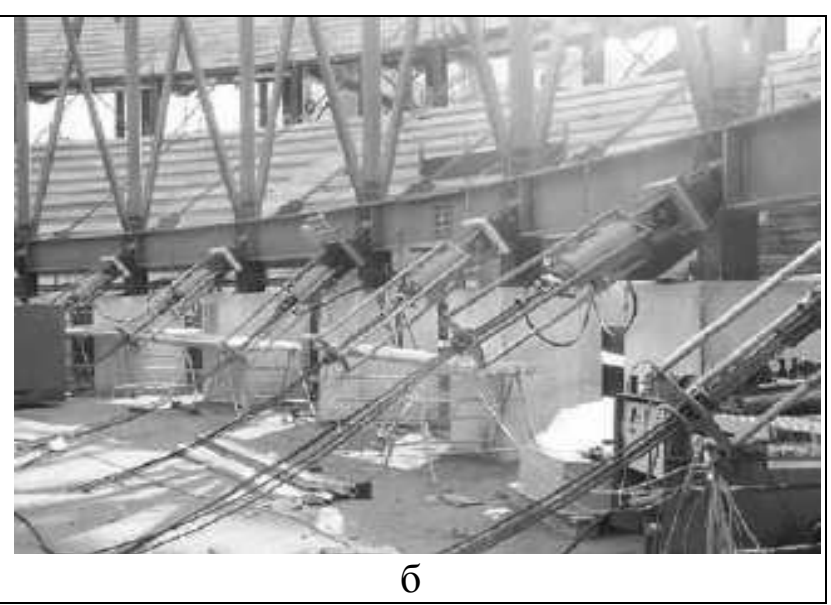

6

а) збірка металевих ферм; б) внутрішнє кільце з закріпленими гідравлічними домкратами

Особливість «Pantadome System» в Хатіві - це відсутність тимчасових вертикальних домкратів. Замість них для переміщення внутрішнього кільця вгору, було застосовано укорочення 44 елементів радіального натягу, що з'єднують нижні вузли решітки ферм 3 нижнім поясом внутрішнього кільця. Підйом куполу показано на рис. 9. Загальна вага конструкції покриття склала 4530 кН. Під час зведення покриття шарнірно закріплені опорні колони повернулися відносно вертикалі на кут від $+21,3^{\circ}$ (внутрішній початковий нахил) до вертикального положення 3 максимальним нахилом назовні $-3,4^{\circ}$ в проміжному положені. Внутрішнє кільце перемістилося на висоту 16,87 м, а довжина нижніх радіальних елементів ферм скоротилася на 5,33 м.

(1)

(3)
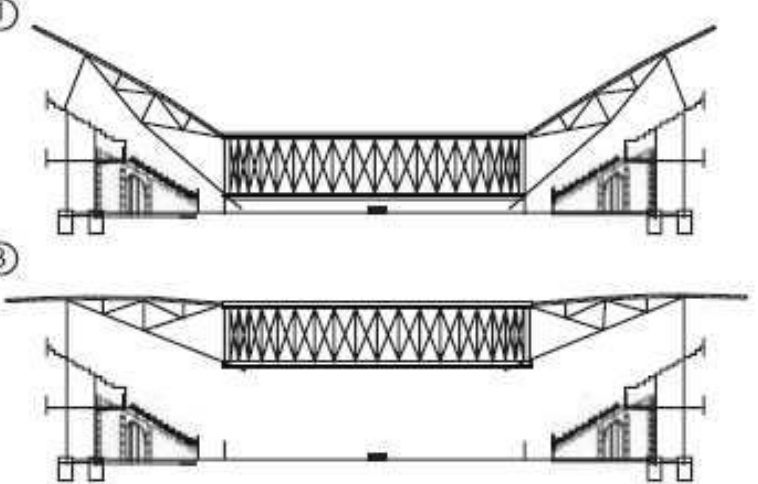

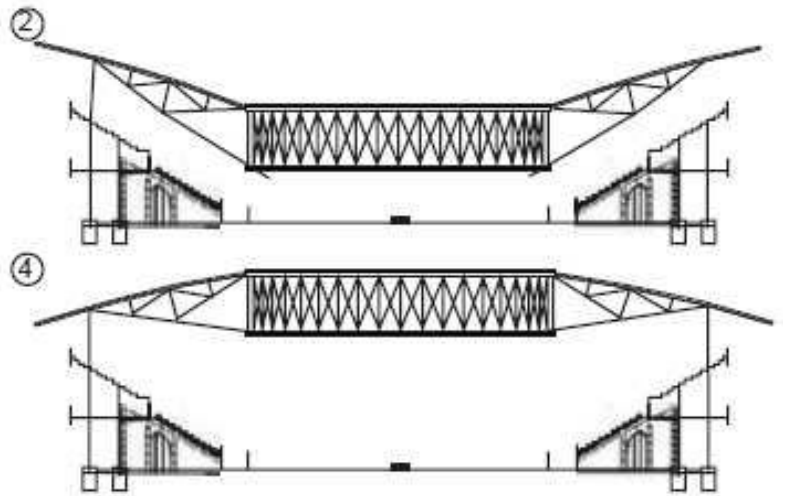

(4)

Рис.9. Етапи зведення куполу за принципами «Pantadome System». Поперечний переріз

Трансформацію плоскої плити в оболонку додатної кривизни можна виконати, якщо вона складається 3 ортотропного матеріалу, який дозволяє великі деформації при низькій напрузі в одному напрямку і набагато міцніший в іншому. В статті [11] наведено спосіб, 
завдяки якому плоска пластина з міцного матеріалу (наприклад, клеєної деревини, бетону) i м'якого компоненту (наприклад, полістиролу) за допомогою пневматичної опалубки та натягу металевих канатів по контуру трансформується в оболонку додатної кривизни.

Для прикладу обраний купол діаметром 12 м і висотою 2,16 м. На поверхні землі виготовлена плоска кругла плита 332 сегментів діаметром 13 м (рис. 10, а). Товщина двошарової плити склала 100 мм (нижній шар полістиролу - 50 мм, верхній шар залізобетону - 50 мм). По контуру утворено залізобетонне ребро шириною 150 мм і товщиною 120 мм для розміщення двох канатів натягу під час трансформації.

На рис. 10 б, в наведено результати трансформації плоскої круглої плити в купол. Спочатку центр плити підняли на 20 мм за допомогою пневматичної опалубки для компенсації власної ваги оболонки. Максимальний тиск склав 6 мбар. Потім одночасно навантажені металеві канати в обох анкерних блоках до 40 кН. Збільшення напруги канатів привело до зменшення діаметру і підйому центру оболонки. Коли було досягнуто остаточної трансформації, канати були закріплені з двох боків на якорях. Під час трансформації плити в купол зменшилися: - радіус кривизни від нескінченного для пластини до 9,365 м; - діаметр 3 13 м до 12 м; - сегменти полістиролу по колу від 144 мм до 38 мм.

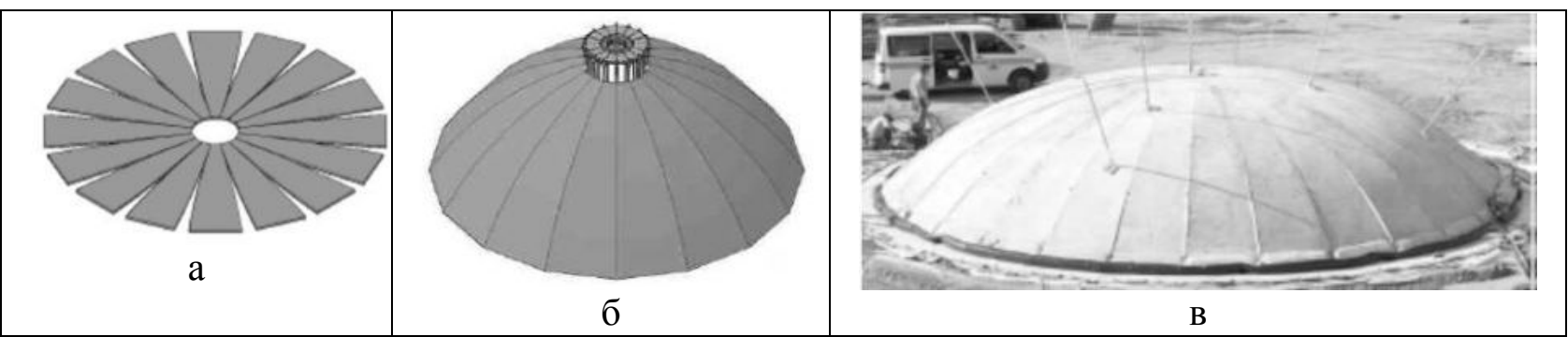

Рис. 10. Трансформація плоскої круглої плити в купол: а) схема плоскої плити на поверхні землі; б) схема куполу в проектному положенні; в) модель куполу в зведеному стані

В науково-практичній літературі не достатньо матеріалів для виконання аналізу оболонок що просторово трансформуються під час експлуатації і тому було виконано дослідження оболонок що трансформуються під час зведення за допомогою пневматичної опалубки. Показники досліджених сучасних натурних оболонкових покрить різної геометрії дали можливість отримати математичні моделі, що дозволяють виконувати попередню оцінку нових конструкцій оболонок на стадії проектування (таблиця 1). В таблиці Ү(I) відношення стріли підйому до прольоту (діаметру) оболонки покриття в плані.

Таблиця 1

Математичні моделі оболонок різної геометрії

\begin{tabular}{|l|c|}
\hline \multicolumn{1}{|c|}{ Поверхня оболонки покриття } & Висота оболонки, м \\
\hline Купол, діаметром $30-150 \mathrm{~m}$ & $\mathrm{Y}(1)=\left(-0,0048 \times \mathrm{D}^{2}+1,6095 \times \mathrm{D}+76,3304\right) \times 10^{-3}$ \\
\hline Додатної кривизни, розміром $30-120 \mathrm{~m}$ & $\mathrm{Y}(2)=\left(-0,0526 \times \mathrm{L}^{2}+7,8325 \times \mathrm{L}+128,2428\right) \times 10^{-3}$ \\
\hline Від'ємної кривизни, розміром $30-90 \mathrm{M}$ & $\mathrm{Y}(3)=\left(-0,0124 \times \mathrm{L}^{2}+3,5285 \times \mathrm{L}+29,9667\right) \times 10^{-3}$ \\
\hline Шатрового типу, розміром $20-80 \mathrm{~m}$ & $\mathrm{Y}(4)=\left(-0,0199 \times \mathrm{L}^{2}+4,6748 \times \mathrm{L}+120,7339\right) \times 10^{-3}$ \\
\hline Довга циліндрична, розміром $15-45 \mathrm{~m}$ & $\mathrm{Y}(5)=\left(0,0057 \times \mathrm{L}^{2}+(-0,8143) \times \mathrm{L}+86,5095\right) \times 10^{-3}$ \\
\hline Коротка циліндрична, розміром 30-150 м & $\mathrm{Y}(6)=\left(-0,0025 \times \mathrm{L}^{2}+0,7035 \times \mathrm{L}+209,4094\right) \times 10^{-3}$ \\
\hline
\end{tabular}

Висновки. Для досягнення мети виконано аналіз розвитку сучасних конструктивних рішень просторової трансформації оболонок, що отримали найбільш високу оцінку під час експлуатації, і є перспективним для подальшого дослідження та розвитку. Найбільш раціональними $є$ конструктивні рішення трансформованих покрить зі змінною формою що аналізуються комп'ютерними програмами, а їх трансформація виконується робототехнікою. Математичні моделі побудовані за результатами обробки великої кількості оболонок різної 
геометрії, зведених за допомогою пневматичної опалубки, а їх використання дає можливість визначати висоту оболонки при проектуванні.

Для подальших досліджень важливо дослідити можливість розповсюдження принципів «Pantadome System» на оболонки складної геометрії, а також просторову трансформацію оболонок з застосуванням робототехніки.

\section{Література}

1. Шаталюк Ю. В. Принципи формування адаптивної архітектури в контексті сталого розвитку міського середовища: дис. ... кандидата архітектури: 18.00 .02 / Ю. В. Шаталюк. Харків: ХНУБА, 2018. - 246 с.

2. Зимин В.Н. Экспериментальное определение динамических характеристик крупногабаритных трансформируемых космических конструкций / В.Н. Зимин // Вестник МГТУ им. Н.Э. Баумана. Сер. “Машиностроение”, 2011. - №1. - С. 47-56.

3. Шугаев В.В. Трансформируемые большепролетные конструкции покрытий / В.В. Шугаев // Пространственные конструкции зданий и сооружений (Исследования, расчет, проектирование и применение). - М.: МОО «Пространственные конструкции», 2008. - Вып. 11. - C. 212-219.

4. Asefi M. Nature and Kinetic Architecture: The Development of a New Type of Transformable Structure for Temporary Applications / M. Asefi, A. Foruzandeh // Journal of Civil Engineering and Architecture (USA), 2011. - Vol. 5. - No. 6. (Serial No. 43). - P. 513-526.

5. Asefi M. Transformation and movement in architecture: the marriage among art, engineering and technology / M. Asefi // Procedia - Social and Behavioral Sciences, 2012. -Vol. 51. - P. 1005-1010.

6. De Temmerman, N. Design and Analysis of Deployable Bar Structures for Mobile Architectural Applications. Dissertation submitted in fulfilment of the requirements for the award of the degree of Doctor in de Ingenieurswetenschappen (Doctor in Engineering) Vrije Universiteit Brussel. - Brussels, 2007.

7. Jensen, F.V. Concepts for retractable roof structures. Dissertation submitted to the University of Cambridge for the degree of Doctor of Philosophy. - Cambridge, 2004.

8. Inoue F. Development of Adaptive Construction Structure by Variable Geometry Truss / F. Inoue // Robotics and Automation in Construction, 2008, P. 253-272.

9. Kawaguchi M. Application of pantadome system to long-span roof structures / $\mathrm{M}$. Kawaguchi // IABSE reports, 1994. - Vol. 71. - P. 91-100.

10. Lazaro C. Detailing and construction of the pantadome roof structure for a bullring in Xativa (Spain) / C. Lazaro, A. Domingo // International Journal of Space Structures, 2010. - Vol. 25. - No. 4. - P. 229-241.

11. Kollegger J. The building of ice and concrete shells by employing pneumatic formwork / J. Kollegger, B. Kromoser, S. Dallinger // Proceedings: Second International Conference on Flexible Formwork. Bath, University of Bath, 27-29 June 2012.

\section{References}

[1] Shatalyuk YU. V. Pryntsypy formuvannya adaptyvnoyi arkhitektury v konteksti staloho rozvytku mis'koho seredovyshcha: dys. ... kandydata arkhitektury: 18.00.02 / YU. V. Shatalyuk. - Kharkiv: KHNUBA, 2018. - 246 s.

[2] Zimin V.N. Eksperimental'noye opredeleniye dinamicheskikh kharakteristik krupnogabaritnykh transformiruyemykh kosmicheskikh konstruktsiy / V.N. Zimin // Vestnik MGTU im. N.E. Baumana. Ser. "Mashinostroyeniye", 2011. - №1. - S. 47-56.

[3] Shugayev V.V. Transformiruyemyye bol'sheproletnyye konstruktsii pokrytiy / V.V. Shugayev // Prostranstvennyye konstruktsii zdaniy i sooruzheniy (Issledovaniya, raschet, 
proyektirovaniye i primeneniye). - M.: MOO «Prostranstvennyye konstruktsii», 2008. - Vyp. 11. - S. 212-219.

[4] Asefi M. Nature and Kinetic Architecture: The Development of a New Type of Transformable Structure for Temporary Applications / M. Asefi, A. Foruzandeh // Journal of Civil Engineering and Architecture (USA), 2011. - Vol. 5. - No. 6. (Serial No. 43). - P. 513 526.

[5] Asefi M. Transformation and movement in architecture: the marriage among art, engineering and technology / M. Asefi // Procedia - Social and Behavioral Sciences, 2012. -Vol. 51. - P. 1005-1010.

[6] De Temmerman, N. Design and Analysis of Deployable Bar Structures for Mobile Architectural Applications. Dissertation submitted in fulfilment of the requirements for the award of the degree of Doctor in de Ingenieurswetenschappen (Doctor in Engineering) Vrije Universiteit Brussel. - Brussels, 2007.

[7] Jensen, F.V. Concepts for retractable roof structures. Dissertation submitted to the University of Cambridge for the degree of Doctor of Philosophy. - Cambridge, 2004.

[8] Inoue F. Development of Adaptive Construction Structure by Variable Geometry Truss / F. Inoue // Robotics and Automation in Construction, 2008, P. 253-272.

[9] Kawaguchi M. Application of pantadome system to long-span roof structures / M. Kawaguchi // IABSE reports, 1994. - Vol. 71. - P. 91-100.

[10] Lazaro C. Detailing and construction of the pantadome roof structure for a bullring in Xativa (Spain) / C. Lazaro, A. Domingo // International Journal of Space Structures, 2010. - Vol. 25. - No. 4. - P. 229-241.

[11] Kollegger J. The building of ice and concrete shells by employing pneumatic formwork / J. Kollegger, B. Kromoser, S. Dallinger // Proceedings: Second International Conference on Flexible Formwork. Bath, University of Bath, 27-29 June 2012.

\title{
ПРОСТРАНСТВЕННАЯ ТРАНСФОРМАЦИЯ КОНСТРУКТИВНЫХ ЭЛЕМЕНТОВ СОВРЕМЕННЫХ ОБОЛОЧЕК ПОКРЫТИЙ
}

\author{
Коломийчук Г.П., к.Т.Н., доцент \\ gp11klm@gmail.com, ORCID: 0000-0003-4484-7791
}

Коломийчук В.Г., студентка veronika.kolomy@gmail.com Одесская государственная академия строительства и архитектуры

\begin{abstract}
Аннотация. В настоящее время в практике строительства уникальных большепролетных пространственных оболочечных покрытий чаще других используются принципы адаптивной архитектуры. Построенные здания и сооружения приобретают искусственный интеллект для экономичной и комфортной эксплуатации и могут с помощью компьютерных программ реагировать на меняющиеся условия внешних воздействий. Такие здания и сооружения состоят из конструктивных систем способных трансформироваться для удовлетворения нужд эксплуатации. Особая сложность проектирования трансформируемых пространственных конструктивных систем состоит в том, что в процессе эксплуатации значительно изменяется их расчетная схема, а все многочисленные экстремальные изменения необходимо заранее спрогнозировать.

Рассмотрены в статье конструкции, которые могут менять свои геометрические размеры, то есть трансформироваться во время эксплуатации, для решения задач адаптивной архитектуры по созданию надлежащего микроклимата внутри зданий и сооружений.

Выделены в исследовании только пространственные конструкции, состоящие из элементов сложного перемещения в пространстве, хотя существует много построенных трансформируемых оболочек покрытий с более простой трансформацией в пространстве (горизонтальной, вокруг вертикальной оси, по направляющим опорным элементам поверхности оболочек переноса).
\end{abstract}


Развитие таких конструкций имеет много направлений. Одно из сложнейших развитие мобильных конструкций в космической отрасли, когда на орбиту доставляется крупногабаритная конструкция, упакованная в контейнер минимальных размеров, а на орбите она автоматически раскрывается до необходимых габаритов.

Приведены современные подходы в трансформации конструкций, получившие наиболее высокую оценку во время нового строительства, реконструкции и эксплуатации зданий и сооружений, и являются перспективными для дальнейших исследований и применения. Для примеров использованы пространственные оболочечные конструкции, а также те эксплуатация и строительство которых осуществляется с помощью компьютерных программ.

Выполнен анализ построенных оболочек различной формы с использованием пневматической опалубки для получения математических моделей, позволяющих определять оптимальные габаритные размеры и использовать в проектировании.

Ключевые слова: пространственная трансформация оболочек, умные конструкции, адаптивная архитектура, оптимальные размеры оболочек, реконструкция.

\title{
SPATIAL TRANSFORMATION OF STRUCTURAL ELEMENTS OF MODERN COATINGS SHELLS
}

\author{
Kolomiychuk G.P., PhD., Assistant Professor, \\ gp11k1m@gmail.com, ORCID: 0000-0003-4484-7791 \\ Kolomiichuk V.G., student \\ veronika.kolomy@gmail.com
}

Odessa State Academy of Civil Engineering and Architecture

\begin{abstract}
Currently, the principles of adaptive architecture are most often used in the practice of building unique large-span spatial shell coverings. Constructed buildings and structures acquire artificial intelligence for economical and comfortable operation and can use computer programs to respond to changing environmental conditions. Such buildings and structures consist of structural systems capable of transforming to meet the needs of operation. The particular complexity of the design of transformable spatial structural systems is that their design scheme changes significantly during operation, and all numerous extreme changes must be predicted in advance.

Structures that can change their geometric dimensions, that is, transform during operation, are considered in the article to solve the problems of adaptive architecture to create the proper microclimate inside buildings and structures.

Only spatial structures consisting of elements of complex displacement in space were identified in the research, although there are many constructed transformable shells of coverings with a simpler transformation in space (horizontal, around a vertical axis, along the guiding support elements of the surface of the transfer shells).

The development of such structures has many directions. One of the most difficult is the development of mobile structures in the space industry, when a large-sized structure packed in a container of minimum dimensions is delivered into orbit, and in orbit it automatically opens to the required dimensions.

Modern approaches to the transformation of structures are given, which were highly appreciated during the new construction, reconstruction and operation of buildings and structures, and are promising for further research and application. For examples, spatial shell structures were used, as well as those operation and construction of which are carried out using computer programs.

The analysis of the constructed shells of various shapes using pneumatic formwork to obtain mathematical models to determine the optimal overall dimensions and use in the design.

Keywords: spatial transformation of shells, smart constructions, adaptive architecture, optimal shell sizes, reconstruction.
\end{abstract}




\title{
ЗАБЕЗПЕЧЕННЯ ВОГНЕСТІЙКОСТІ ЕКСПЛУАТОВАНИХ СТАЛЕВИХ КОНСТРУКЦІЙ
}

\author{
Маладика І.Г., к.т.н., доц., \\ maladyka@gmail.com; ORCID: 0000-0001-8784-2814 \\ Шкарабура I.М., ад’юнкт, \\ Черкаський інститут пожежної безпеки \\ імені Героїв Чорнобиля НУЦЗ України, \\ shkgg.13@ukr.net; ORCID: 0000-0002-3882-7623; \\ Антошина T.В., к.т.н., \\ ТОВ «ГЛОБАЛ ПРОДЖЕКТ», Україна, \\ tvantos@ukr.net; ORCID: 0000-0002-6601-6078; \\ Іванов Б.В., інженер, \\ ТОВ «МегаСП», м. Київ, Україна \\ ivanov@megabp.com; ORCID: 0000-0002-9203-2987.
}

\begin{abstract}
Анотація. Узагальнено сучасний стан питання, поставлено задачі досліджень, зазначено основні передумови застосування захисту експлуатованих сталевих будівельних конструкцій від високотемпературних впливів. Наведено огляд результатів досліджень різних аспектів захисту конструкцій, визначення технічного стану в процесі експлуатації після різних впливів та його регулювання шляхом ремонту, підсилення або заміни. Аналіз існуючих методик дозволив встановити, що відсутні доведені до практичного використання методи розрахунку, оцінки їхнього технічного стану та обгрунтування можливості подальшої експлуатації сталевих конструкцій будівель та споруд після різних впливів.
\end{abstract}

Ключові слова: сталеві конструкції, визначальні параметри, технічний стан, регулювання, вогнестійкість.

Вступ. Постановка проблеми. Надійність будівельних конструкцій повинна бути забезпечена відповідно до вимог чинних нормативних документів. При проектуванні конструкцій повинні бути забезпечені експлуатаційна придатність і безпека протягом строку експлуатації, який визначається в завданні на проектування. Окрім цього, проектування конструкцій необхідно виконувати 3 урахуванням вимог охорони навколишнього середовища, а також інших особливих умов, наведених у завданні на проектування $[1,2,3]$.

Основні вимоги щодо проектування сталевих конструкцій викладено в розділі 5 ДБН B.2.6-198:2014 [2].

Результати досліджень застосовано при обгрунтуванні можливості подальшої експлуатації сталевих конструкцій, які отримали пошкодження після пожежі.

Аналіз останніх джерел досліджень і публікацій. Широке застосування сталеві конструкції отримали при будівництві одноповерхових виробничих будівель, несучих каркасів висотних будівель, великопрольотних будівель громадського призначення, будівель спеціального призначення тощо [1].

В Україні прийнято ряд документів, в яких встановлено обов'язкові вимоги безпеки, в т. ч. і пожежної, в будівництві (стосовно будівель зі сталевим каркасом): ДБН В.2.6-198:2014 [2], ДБН В.1.2-2:2006 [3], ДСТУ-Н Б В.1.2-18:2016 [4], ДСТУ Б В.2.6-210:2016 [5], ДСТУ-Н Б В.2.6-211:2016 [6], ДСТУ Б В.1.1-17:2007 (ENV 13381-4:2002, NEQ) [7], ДСТУ-Н-П Б В.1.129:2010 [8].

Прийняття цих та інших нормативних документів дозволяє проектувати нові об'єкти. В той же час, за статистичними даними останніх років в Україні в середньому виникає 50-60 пожеж, які досягають критеріїв надзвичайних ситуацій. Однією 3 основних причин 
виникнення надзвичайних ситуацій є застарілість основних фондів та аварійний стан значної частини мереж комунального господарства.

Зростання ризику виникнення техногенних надзвичайних ситуацій в Україні обумовлено тим, що в останні роки в найбільш відповідальних галузях об'єкти підвищеної небезпеки та потенційно небезпечні об'єкти мають напрацювання проектного ресурсу на рівні 50-70\%, а іноді досягають передаварійного рівня.

Для подальшої безпечної експлуатації будівель та споруд необхідно проводити постійну діагностику конструкцій, визначати контрольовані параметри конструкцій, розробляти способи захисту конструкцій у відповідності з вимогами чинних нормативних документів, в т.ч. і від високотемпературних впливів.

Вибір схеми підсилення сталевих конструкцій, які отримали різні пошкодження за час експлуатації, можна вважати багатоваріантним завданням. Це питання вивчали вітчизняні та закордонні вчені, які досліджували різні аспекти цієї проблеми: М. Барабаш, Б. Бартелемі, О. Башинська, В. Бушев, С. Беленя, О. Голоднов, В. Корсун, О. Кричевський, І. Мосалков, К. Муханов, Г. Плюсніна, В. Пчелінцев, В. Ройтман, М. Стрілецький, С. Фомін, В. Шимановський, А. Яковлєв та ін. Рішення завдань оптимізації ускладнюється ще й тим, що основним критерієм оптимальності підсилення часто $є$ не економія матеріалу або зниження вартості робіт із підсилення, а забезпечення найбільшої його технологічності. При цьому під технологічністю розуміється не зручність проведення робіт, а можливість їх здійснення без зупинки виробництва з метою зниження виробничих витрат [9].

Через все вищевикладене передбачається, що йдеться про розрахунок i застосування підсилення конструкції за цілком певною схемою із заздалегідь заданими параметрами і при відомих впливах на неї. Підтвердженням правомірності прийнятої схеми підсилення або вирівнювання конструкцій можуть бути тільки результати експериментальних досліджень (зокрема, [9]), а також результати постійного моніторингу у відповідності з вимогами ДСТУ-Н Б В.1.2-17:2016 [10].

В статті наведено приклад розслідування руйнувань конструкцій будівлі зі сталевим каркасом після пожежі внаслідок нехтування вимогами чинних нормативних документів.

Формулювання мети та методів дослідження. Мета цієї роботи полягає в розробці взаємозв'язаних заходів щодо визначення параметрів технічного стану та оцінювання вогнестійкості експлуатованих сталевих конструкцій, будівель та споруд в цілому, обгрунтування можливості продовження терміну експлуатації або необхідності регулювання технічного стану та вогнестійкості шляхом ремонту, підсилення або заміни конструкцій i вогнезахисних матеріалів.

Оцінка технічного стану та вогнестійкості виконується для визначення можливості подальшої експлуатації сталевих конструкцій в такій послідовності $[1,2,4]$ :

- аналіз технічної документації;

- візуальне обстеження конструкцій;

- інструментальне обстеження конструкцій;

- аналіз результатів візуального й інструментального обстеження;

- виконання перевірочних розрахунків (за необхідності) 3 урахуванням можливості розвитку особливих впливів (наприклад, вибуху);

- оцінка технічного стану та вогнестійкості на основі проведених досліджень;

- висновок про можливість подальшої експлуатації та рекомендації щодо приведення конструкцій в придатний для експлуатації стан (за необхідності);

- визначення технічного стану, залишкового ресурсу та вогнестійкості з урахуванням можливості розвитку особливих впливів (за необхідності).

Основний матеріал і результати. Для оцінки технічного стану та вогнестійкості конструкцій використовуються $[1,5,6]$ :

- критерій відповідності конструкції (споруди) робочій документації (розміри, конструктивні особливості, засоби захисту від агресивних впливів оточуючого середовища, вогнестійкості тощо); 
- критерій відповідності конструкції (споруди) визначальним параметрам технічного стану та вогнестійкості (наявність або відсутність неприпустимих дефектів, відповідність застосованих матеріалів і засобів вогнезахисту вимогам проекту та чинних нормативних документів України тощо) і задоволення вимогам розрахунку за граничними станами.

Удосконалення методики розрахунку із залученням сучасних програмних комплексів на основі методу скінчених елементів (ПК МСЕ) з метою визначення залишкової несучої здатності сталевих конструкцій, що зазнали на протязі певного часу дію різних чинників впливу, вимагає використання такої моделі деформування матеріалів, яка б включала всі етапи його роботи від початку навантаження до повного руйнування.

Таким чином, для удосконалення методики оцінювання технічного стану та вогнестійкості експлуатованих конструкцій будівель та споруд для доповнення положень чинних нормативних документів $[2,4,5]$ необхідно вирішити наступні завдання $[1,9]$ :

- розробити комплекс взаємозв'язаних заходів щодо визначення параметрів напружено-деформованого стану (НДС), технічного стану та вогнестійкості;

- встановити величини параметрів та критерії технічного стану, які були б придатні для розрахунків НДС, технічного стану та вогнестійкості сталевих конструкцій;

- розробити методи оцінки НДС, залишкової несучої здатності та вогнестійкості сталевих конструкцій будівель та споруд і можливості їхнього регулювання для подальшої експлуатації шляхом ремонту, підсилення або заміни.

Оцінка технічного стану конструкцій передбачає вивчення технічної документації. До технічної документації відносять нормативну, проектну, виконавчу й експлуатаційну документацію. Технічна документація на вогнезахисні матеріали повинна містити $[7,8]$ :

- опис матеріалу;

- якісні характеристики матеріалу та показники його вогнезахисної ефективності згідно документів з оцінки відповідності;

- дані про сировину та матеріали, з яких виготовляється вогнезахисна продукція;

- опис методів та (або) обладнання за допомогою яких контролюється якість засобів, що виробляються, їхня ідентифікація та методи контролю під час і після обробляння;

- настанови з вогнезахисного обробляння, а також зі збереження та транспортування засобів вогнезахисту (регламент робіт з вогнезахисту);

- довговічність (строк експлуатаційної придатності) та гарантійні зобов'язання;

- іншу інформацію, що описує всі відповідні елементи, які пов'язані з виробництвом та 3 необхідною системою оцінки (перевірки) сталості характеристик якості вогнезахисних засобів та робіт щодо їхнього застосування.

Для проведення вогнезахисних робіт на кожен вогнезахисний засіб (систему вогнезахисту) виробник або його уповноважений представник розробляє технічну документацію 3 вогнезахисного обробляння - регламент робіт 3 вогнезахисту, в якому встановлюють порядок та всі можливі процедури щодо застосування та підтримання експлуатаційної придатності вогнезахисту.

Відповідальність за повноту та достовірність інформації, яку зазначено в технічній документації на вогнезахисні матеріали та документації з вогнезахисного обробляння, покладається на виробника та (або) його уповноваженого представника.

Особливу увагу під час визначення відповідальності треба приділяти документації, що містить умови підтримання експлуатаційної придатності вогнезахисту.

Методика визначення значень параметрів, що характеризують механізм накопичення змін в сталевих конструкціях, потребує виконання наступних процедур $[4,5,10]$ :

- проведення спостережень за поточним станом сталевих конструкцій службами організації, яка експлуатує будівлю (постійний візуальний контроль);

- періодичні вимірювання геометричних параметрів конструкції, постійний контроль положення будівлі;

- систематичні геодезичні спостереження з фіксацією отриманих результатів;

- візуальний систематичний контроль технічного стану сталевих конструкцій 
службами організації, що експлуатує будівлю;

- періодичні обстеження сталевих конструкцій 3 визначенням контрольованих параметрів та їхнього технічного стану;

- встановлення механізму накопичення необоротних змін в сталевих конструкціях;

- оцінювання вогнестійкості експлуатованих сталевих конструкцій;

- на основі механізму накопичення необоротних змін в сталевих конструкціях i результатів геодезичних спостережень - прогноз зміни контрольованих параметрів i технічного стану сталевих конструкцій в часі, визначення залишкового ресурсу конструкцій.

Як критерії відмов і пошкоджень необхідно розглядати граничні величини параметрів технічного стану (наявність або відсутність тріщин, прогини, переміщення, руйнування захисних покриттів тощо), які встановлено проектною або нормативною документацією.

Перелік найбільш характерних визначальних параметрів для оцінки технічного стану сталевих конструкцій наведено в у відповідних таблицях ДСТУ Б В.2.6-210:2016 [5].

На основі встановлених ознак 3 використанням прогнозної зміни їх в часі встановлюють критерії вичерпання несучої здатності конструкцій 3 вказівкою наслідків такого виду відмови, а також розроблюють рекомендації щодо запобігання вичерпанню несучої здатності конструкцій.

Вихід з ладу конструкцій будівель та споруд, як правило, не виникає раптово i розглядається як результат старіння - накопичення пошкоджень при дії корозійного середовища, підвищених температур, статичних, динамічних і особливих навантажень.

Візуальне обстеження технічного стану виконується шляхом проведення технічного огляду конструкцій. Візуальним методом виявляють видимі дефекти сталевих конструкцій, а також визначають явні та передбачувані причини їхнього виникнення. Остаточно причини появи дефектів уточнюють після вивчення технічної документації, а також в ході інструментального обстеження.

Виявлення при обстеженні конструкцій дефектів i пошкоджень повинно супроводжуватися порівнянням відповідності обстежуваних конструкцій і умов їхньої експлуатації вимогам нормативної та проектної документації.

Технічний стан вогнезахисту експлуатованих сталевих конструкцій перевіряється відповідно до проектної та технічної документації на застосовану систему вогнезахисту. В загальному випадку достатньо визначення зовнішнього вигляду та можливих при цьому змін у кольорі та фактурі матеріалів, надійності систем кріплення та інших фізичних показників. За необхідності проводять визначення характеристичних показників застосованих у системі вогнезахисту матеріалів, а саме [7, 8]:

- при перевірці реактивних вогнезахисних покривів - визначення товщини покриву та коефіцієнту спучення;

- при перевірці пасивних вогнезахисних покривів - визначення товщини покриву.

В ході виконання перевірочних розрахунків передбачається $[1,2,3]$ :

- математичне моделювання конструкцій MCE 3 урахуванням встановленого деформованого стану;

- розрахунок конструкцій і визначення зусиль і деформацій в елементах розрахункової схеми;

- порівняння характеру деформації реального об'єкту та математичної моделі й уточнення, у разі потреби, характеристик жорсткості матеріалів елементів моделі;

- розрахунок уточненої моделі, визначення зусиль і переміщень;

- перевірка дотримання умов, що забезпечують несучу здатність і деформативність будівельних конструкцій, оцінка їхнього технічного стану;

- проектування підсилення (за необхідності);

- коректування розрахункової схеми споруди з урахуванням встановлення елементів підсилення і розрахунок нової моделі та вогнестійкості.

Остаточна оцінка технічного стану та вогнестійкості конструкцій (споруди) проводиться шляхом зіставлення контрольованих параметрів, які визначено в ході 
проведення візуального й інструментального обстежень, 3 відповідними проектними параметрами, а також за результатами перевірних розрахунків.

Як уже було викладено вище, надійність будівельних конструкцій повинна бути забезпечена відповідно до вимог чинних нормативних документів. Конструкції будівель та споруд, які було побудовано до 2007 p., було розраховано на навантаження, в т.ч. i кліматичні, величина яких майже в 1,5 рази менша за сучасні параметри. Нехтування такими обставинами призводить до руйнувань конструкцій і економічних збитків.

В якості приклада нехтування основними вимогами щодо проектування сталевих конструкцій (будівлю побудовано на початку XXI століття) можна привести руйнування конструкцій складської будівлі зі сталевим каркасом внаслідок пожежі [1].

Будівля складу комплексу по зберіганню продуктів харчування ТОВ «Кушнер» в с.м.т. Велика Димерка Броварського району Київської обл. являє собою споруду прямокутної форми в плані загальними розмірами 100x48 м (рис. 1). В осях Г-Т будівля являє собою одноповерхову двохпрольотну споруду зі сталевим каркасом розмірами в плані в осях $108 \times 48$ м, яка являє собою склад для зберігання продуктів харчування. Висота до низу конструкцій 5,25 м. Каркас цієї частини будівлі змонтовано 3 конструкцій комплектної поставки фірми ZAMIL STEEL. Зовнішні стіни виконано з сандвіч-панелей. Покрівля плоска, 3 незначним ухилом. Ступінь вогнестійкості конструкцій - IIIа.

Колони будівлі в осях Г-Т являють собою сталеві конструкції двотаврового профілю, які закріплено до фундаментів за допомогою анкерних болтів М24. Колони по осі 22 виконано зі змінним по висоті перерізом, колони по осях 14 і 18 - постійного перерізу.

Зверху на колони (по осях 18 і 22) обпираються сталеві балки покриття, які складаються з окремих відправних марок. До колон по осі 14 балки закріплюються збоку до поясів. Відправні марки балок виконано змінного перерізу.

Зверху на пояси балок обпираються прогони прольотом 9 м, які виконано з гнутих Сподібних профілів висотою 360 мм.

Просторова жорсткість конструкцій цієї частини будівлі повинна була забезпечуватись за допомогою шарнірно з'єднаних 3 фундаментами колон, балок покриття, які жорстко з'єднано з оголовками колон, балок-розпірок для встановлення на них технологічного обладнання на даху, вертикальних і горизонтальних в'язів, які виконано зі сталевих канатів.

6 квітня 2016 року в будівлі складу сталася пожежа. Пожежа виникла в осях Л-П/14-18, де зберігалось обладнання. В ході обстеження було отримано наступні відомості про пожежу, які необхідні для подальшого детального обстеження конструкцій:

- час виявлення пожежі, початку інтенсивного горіння (пожежа почалась зранку, повністю була ліквідована близько 16 години 6 квітня 2016 року);

- тривалість інтенсивного горіння під час пожежі (пожежа виникла в зоні складування обладнання, тривалість інтенсивного горіння становила приблизно 3 години);

- засоби гасіння пожежі (для гасіння пожежі рятувальники застосували воду);

- місце знаходження осередку займання (осередок займання знаходився в зоні розміщення обладнання в осях Л-П/14-18);

- максимальну температуру середовища під час пожежі (температура перевищувала $1000{ }^{\circ} \mathrm{C} з$ огляду на стан обвалених конструкцій).

Детальне обстеження сталевих конструкцій проводилось в наступній послідовності:

- вивчено наявну документацію по конструкціям і будівлі в цілому;

- ознайомлено з пошкодженим пожежею об'єктом;

- виконано обстеження конструкцій, які залишились в проектному положенні, 3 метою з'ясування їхнього технічного стану після пожежі;

- виконано візуальне обстеження конструкцій, які найбільш постраждали від високотемпературного впливу під час пожежі. Було встановлено, що конструкції не мали вогнезахисних покриттів, а засоби гасіння пожежі не спрацювали (рис. 2, 3);

- виявлено дефекти та пошкодження конструкцій, проведено їхній аналіз, розроблено розрахункову модель МСЕ і виконано розрахунки конструкцій; 


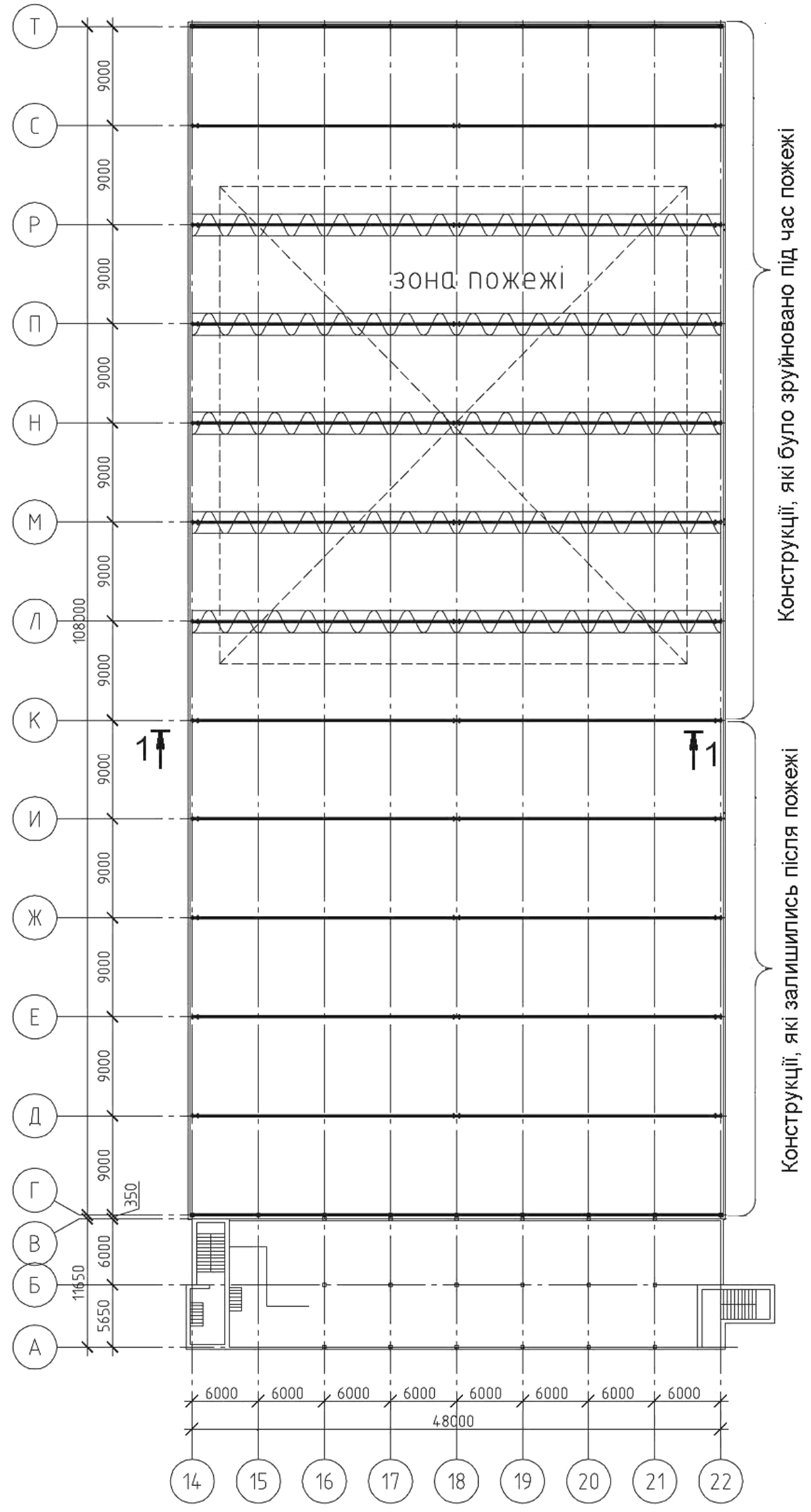

Рис. 1. Схема розташування несучих елементів каркасу після пожежі 


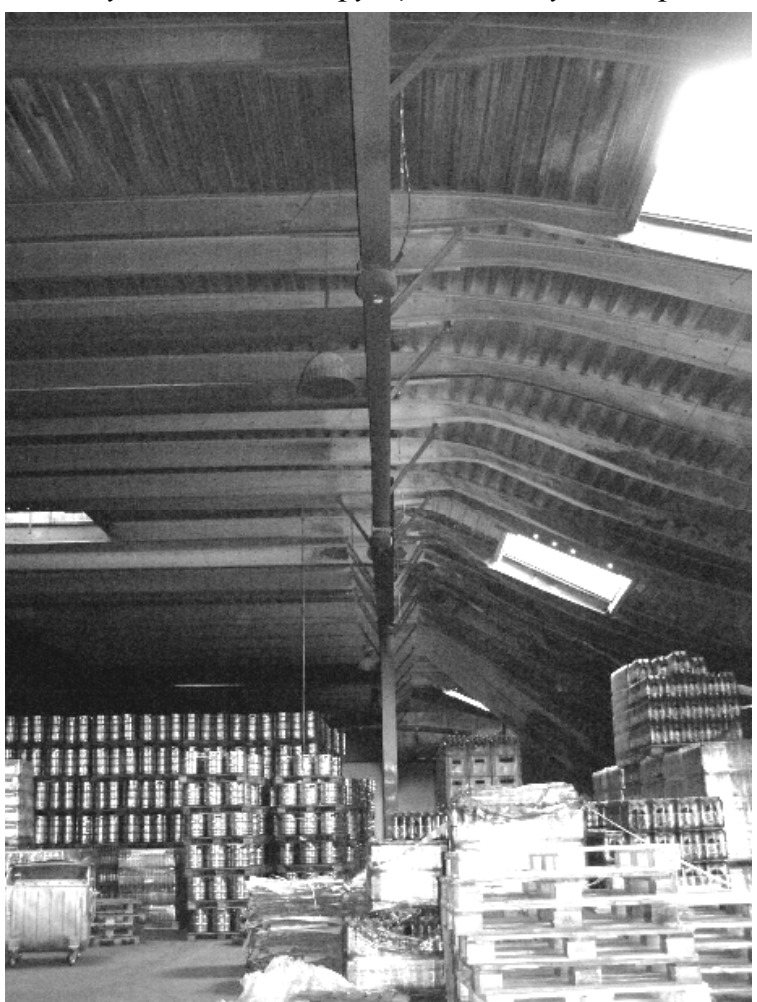

Рис. 2. Обвалення конструкцій каркасу будівлі в осях К-Л після пожежі

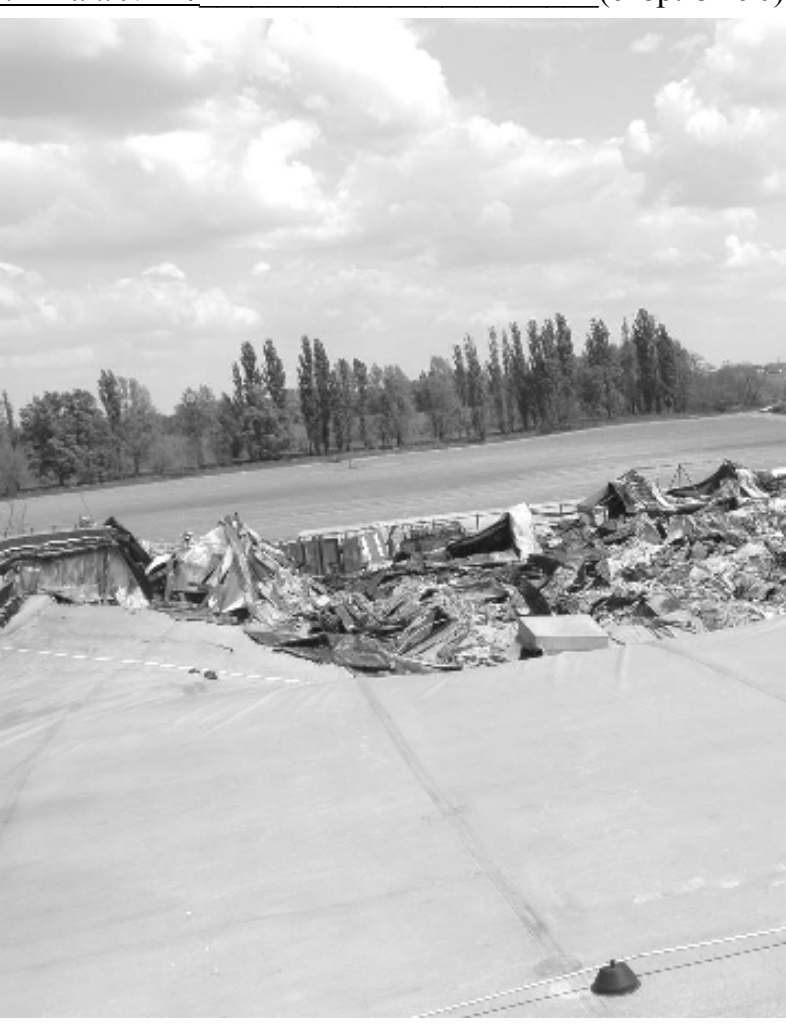

Рис. 3. Вигляд обвалених конструкцій будівлі в осях Г-Т (вигляд з покрівлі)

- підготовлено висновок про технічний стан і можливість подальшої експлуатації будівлі, розроблено проект відновлення будівлі та реалізовано його в натурі.

Подальша експлуатація будівлі передбачається зі зміною функціонального призначення (пропонується розмістити обладнання для випуску товарів народного призначення).

Висновки. В ході проведених досліджень зроблено наступні висновки.

1. Проаналізовано та узагальнено результати досліджень в області визначення вогнестійкості сталевих конструкцій, НДС конструкцій будівель та споруд після різних впливів, обгрунтовано необхідність проведення досліджень в цій області, сформульовано передумови та допущення. В результаті проведеної роботи встановлено, що експлуатовані сталеві конструкції протягом експлуатації та після пожежі можуть втрачати свої властивості внаслідок зміни характеристик міцності та деформативності сталі, руйнування вогнезахисних покриттів та нерівномірних деформацій елементів конструкцій внаслідок локального високотемпературного розігрівання.

2. Удосконалено методику оцінювання технічного стану та вогнестійкості сталевих конструкцій на етапі експлуатації будівель та споруд. Розроблено методи розрахунку конструкцій і вогнестійкості, оцінки технічного стану та можливості його регулювання для подальшої експлуатації конструкцій будівель та споруд. Методи розрахунку базуються на відомих принципах і допущеннях будівельної механіки, теплофізики, охорони праці тощо.

3. Певною мірою результати досліджень було використано при визначенні технічного стану конструкцій будівлі складу комплексу по зберіганню продуктів харчування ТОВ «Кушнер» в с.м.т. Велика Димерка Броварського району Київської обл. після пожежі. За результатами проведених досліджень було розроблено розрахункову схему будівлі 3 використанням ПК ЛІРА, виконано розрахунки, підготовлено висновок про технічний стан та проект відновлення конструкцій будівлі, який реалізовано в натурі. 


\section{Література}

1. Голоднов, О., Антошина, Т., Отрош, Ю. (2017). Про необхідність розрахунку будівель зі сталевим каркасом на температурні впливи. Збірник наукових праць Українського інституту сталевих конструкцій імені В. М. Шимановського, 20, 65-84.

2. ДБН В.2.6-198:2014. Сталеві конструкції. Норми проектування. (2015). - Київ: Мінрегіонбуд України, 199.

3. ДБН В.1.2-2:2006. Навантаження і впливи. Норми проектування. (2007). - Київ: Мінбуд України, 60.

4. ДСТУ-Н Б В.1.2-18:2016. Настанова щодо обстеження будівель і споруд для визначення та оцінки їх технічного стану. (2017). - К.: ДП «УкрНДНЦ», 45.

5. ДСТУ Б В.2.6-210:2016. Оцінка технічного стану сталевих будівельних конструкцій, що експлуатуються. (2017). - К. : Мінрегіон України, 53.

6. ДСТУ-Н Б В.2.6-211:2016. Проектування сталевих конструкцій. Розрахунок конструкцій на вогнестійкість. (2017). Київ: Мінрегіон України, 147.

7. ДСТУ Б В.1.1-17:2007 (ENV 13381-4:2002, NEQ). Вогнезахисні покриття для будівельних несучих металевих конструкцій. Метод визначення вогнезахисної здатності. (2008). - Київ: Мінрегіонбуд України, 65.

8. ДСТУ-Н-П Б В.1.1-29:2010. Вогнезахисне обробляння будівельних конструкцій. Загальні вимоги та методи контролювання. (2011). - Київ: Мінрегіонбуд України, 9.

9. Голоднов, О., Іванов, Б. (2019). Вирівнювання стислих сталевих двотаврових елементів після розвантаження різними способами. Сучасні будівельні конструкції з металу та деревини, 23, 24-32.

10. ДСТУ-Н Б В.1.2-17:2016. Настанова щодо науково-технічного моніторингу будівель і споруд. (2017). - Київ: Мінрегіон України, 45.

\section{References}

[1] Holodnov, O., Antoshyna, T., Otrosh, Yu. (2017). Pro neobkhidnist rozrakhunku budivel zi stalevym karkasom na temperaturni vplyvy. Zbirnyk naukovykh prats Ukrayinskoho instytutu stalevykh konstruktsiy imeni V. M. Shymanovskoho, 20, 65-84.

[2] DBN V. 2.6-198:2014. Stalevi konstruktsiyi. Normi proektuvannja. (2015). - Kyiv: Minregion Ukrayini, 199.

[3] DBN V.1.2-2:2006. Navantagennja i vplivi. Normi proektuvannja. (2007). - Kyiv: Minbud Ukrayini, 60.

[4] DSTU-N B V.1.2-18:2016. Nastanova shchodo obstezhennya budivel i sporud dlya vyznachennya ta oczinky yikh tekhnichnoho stanu. (2017). Kyiv: DP «UkrNDNTs», 45.

[5] DSTU B V.2.6-210:2016. Oczinka tekhnichnogo stanu stalevikh budivelnikh konstrukczij, shho ekspluatuyutsya. (2017). - Kyiv: Minregion Ukrayini, 53.

[6] DSTU-N B V.2.6-211:2016. Proektuvannja stalevikh konstrukczij. Rozrahunok konstrukczij na vognestijkist. (2017). Kyiv: Minregion Ukrayini, 147.

[7] ДСТУ Б В.1.1-17:2007 (ENV 13381-4:2002, NEQ). Vognezahisni pokrittja dlja budivelnikh nesutchikh metalevikh konstrukczij. Metod viznatchennja vognezakhisnoi zdatnosti. (2008). Kyiv: Minregionbud Ukrayini, 65.

[8] DSTU-N-P B V.1.1-29:2010. Vognezahisne obrobljannja budivelnikh konstrukczij. Zagalni vimogi ta metodi kontroluvannja. (2011). - Kyiv: Minregionbud Ukrayini, 9.

[9] Holodnov, O., Ivanov B. (2019). Virivnyuvannya stislikh stalevikh dvotavrovikh elementiv pislya rozvantajennja riznivi sposobami. Sutchasni budivelni konstrukczii z metalu ta derevini, 23, 24-32.

[10] DSTU-N B V.1.2-17:2016. Nastanova shchodo naukovo-tekhnitchnogo monitoringu budivel i sporud. (2017). - Kyiv: Minregion Ukrayini, 45. 


\title{
ОБЕСПЕЧЕНИЕ ОГНЕСТОЙКОСТИ ЭКСПЛУ АТИРУЕМЫХ СТАЛЬНЫХ КОНСТРУКЦИЙ
}

\author{
Маладыка И.Г., к.т.н., доц., \\ maladyka@gmail.com; ORCID: 0000-0001-8784-2814; \\ Шкарабура И.Н., адъюнкт, \\ Черкасский институт пожарной безопасности \\ имени Героев Чернобыля НУГЗ Украины, \\ shkgg.13@ukr.net; ORCID: 0000-0002-3882-7623; \\ Антошина Т.В., к.т.н., \\ ООО «ГЛОБАЛ ПРОДЖЕКТ», Украина, \\ tvantos@ukr.net; ORCID: 0000-0002-6601-6078; \\ Иванов Б.В., инженер \\ ООО «МегаСП», г. Киев, Украина, \\ ivanov@megabp.com; ORCID: 0000-0002-9203-2987.
}

\begin{abstract}
Аннотация. Обобщенно современное состояние вопроса, поставлены задачи исследований, отмечены основные предпосылки применения защиты эксплуатируемых стальных строительных конструкций от высокотемпературных воздействий. Приведен обзор результатов исследований различных аспектов защиты конструкций, определения технического состояния в процессе эксплуатации после различных воздействий и его регулирования путем ремонта, усиления или замены. Проанализированы работы известных ученых в этой области, в которых изложены положения теории расчета строительных конструкций с учетом высокотемпературных воздействий. Анализ существующих методик позволил установить, что отсутствуют доведенные до практического использования методы расчета стальных конструкций, оценки их технического состояния и обоснования возможности последующей надежной эксплуатации конструкций зданий и сооружений после различных воздействий.

Предложена процедура проектирования, устройства и оценки огнестойкости стальных конструкций в процессе эксплуатации.

Приведена методика исследования технического состояния стальных конструкций, поврежденных в результате пожара. В ходе выполнения работ устанавливаются очаг и причины возгорания, величина максимальной температуры при пожаре, зоны термических повреждений, длительность нагревания в разных зонах пожара и т.п. На основе полученных данных готовится вывод о техническом состоянии конструкций и возможности или невозможности возобновления их эксплуатационной пригодности.

В соответствии с требованиями проектной и нормативной документации рекомендуется определять критерии оценки технического состояния и огнестойкости материала и конструкций в целом.

Разработана и апробирована методика получения определяющих параметров технического состояния и огнестойкости стальных конструкций. Предусмотрено, что конструкции и элементы на протяжении всего жизненного цикла в результате старения, деградации и других воздействий могут последовательно находиться в каждом из четырех технических состояний.

Приведены результаты оценки технического состояния и огнестойкости строительных конструкций здания, которые получили повреждения в результате эксплуатации и пожара, и мероприятия по регулированию технического состояния и огнестойкости конструкций.

Ключевые слова: стальные конструкции, определяющие параметры, техническое состояние, регулирование, огнестойкость.
\end{abstract}




\title{
PROVIDING OF FIRE-RESISTANCE OF THE EXPLOITED STEEL CONSTRUCTIONS
}

\author{
Maladyka I., Ph.D. (Tech.), Assoc. Prof, \\ maladyka@gmail.com; ORCID: 0000-0001-8784-2814; \\ Shkarabura I.M., Postgraduate Student, \\ Cherkassy Institute of Fire Safety named after Heroes of Chornobyl \\ of National University of Civil Defense of Ukraine, \\ shkgg.13@ukr.net; ORCID: 0000-0002-3882-7623; \\ Antoshina T., Cand. of Technical Sciences, \\ Global Project LTD, Ukraine, \\ tvantos@ukr.net; ORCID: 0000-0002-6601-6078; \\ Ivanov B., engineer, \\ MegaBP LLC, Kyiv, Ukraine. \\ ivanov@megabp.com; ORCID: 0000-0002-9203-2987.
}

\begin{abstract}
The modern state of the question is generalized, the tasks of researches are put, basic pre-conditions of application of defence of on-the-road steel build constructions are marked from high temperature influences. The review of results of researches of different aspects of defence of constructions is resulted, determinations of the technical state in the process of exploitation after different influences and its adjusting by repair, strengthening or replacement. Works of the known scientists in this area, in which positions of theory of calculation of building constructions are expounded taking into account high temperature influences, are analysed. The analysis of existent methods allowed to set that the methods of calculation of steel constructions, estimations of their technical state and ground of possibility of subsequent reliable exploitation of constructions of buildings and buildings, taken to the practical use absent after different influences.

Procedure of planning, device and estimation of fire-resistance of steel constructions in the process of exploitation is offered.

The method of research of the technical state of steel constructions, damaged as a result of fire is resulted. During implementation of works a hearth and reasons of fire, size of maximal temperature at a fire, areas of thermal damages, is set, duration of heating in the different areas of fire etc. On the basis of findings a conclusion prepares about the technical state of constructions and possibility or impossibility of proceeding in their service ability.

In accordance with requirements it is recommended to determine the criteria of estimation of the technical state and fire-resistance of material and constructions a project and normative document on the whole.

The method of receipt of determining parameters of the technical state and fire-resistance of steel constructions is developed and approved. It is foreseen, that constructions and elements during all of life cycle as a result of senescence, degradation and other influences can consistently be in each of four technical states.

The results of estimation of the technical state and fire-resistance of constructions of the buildings, which got damage as a result of exploitation of both fire and measure on adjusting of the technical state and fire-resistance of constructions are presented.
\end{abstract} resistance.

Key words: steel constructions, determining parameters, technical state, adjusting, fire- 


\title{
ПРАКТИЧНІ ПІДХОДИ ДО РОЗРАХУНКУ НАДІЙНОСТІ БАГАТОБОЛТОВИХ З'ЄДНАНЬ ЛИСТІВ КОРПУСУ СИЛОСНИХ СМНОСТЕЙ
}

\author{
Махінько А.В., д.т.н., с.н.с. \\ ТОВ «Етуаль» \\ pasargada1981@gmail.com, ORCID 0000-0002-9147-7087 \\ Махінько Н.О., к.т.н. \\ Наџіональний авіаційний університет \\ pasargada1985@gmail.com, ORCID 0000-0001-8120-6374
}

\begin{abstract}
Анотація. Дана стаття присвячена питанням практичного розрахунку надійності квазіоднорідних болтових з'єднань корпусу тонкостінних конструкцій сталевих силосів. Неоднорідність з'єднання обумовлювалася присутністю в стику болтів двох класів міцності. При розрахунках надійність системи визначалася через імовірність безвідмовної роботи в просторі коефіцієнту критичного фактору. Значення коефіцієнту критичного фактору $\epsilon$ відношенням випадкового параметру узагальненого зусилля до випадкової величини несучої здатності з'єднання і знаходиться відповідно до системи умов, при яких забезпечується надійність неоднорідного з'єднання. В статті також досліджена залежність рівня надійності від впливу різної кількості непроєктних болтів та подана ії логічна інтерпретація.
\end{abstract}

Ключові слова. Імовірнісний розрахунок, болтові з'єднання, силос, надійність, імовірність безвідмовної роботи, коефіцієнт критичного фактору.

Вступ. Проблема надійності конструкцій будівель і споруд є однією з найважливіших наукових задач, що порушується в області розрахунку будівельних конструкцій. Це пов'язано не лише з отриманням на їі основі більш виправданих з економічної точки зору результатів, але і загальною сутністю поняття надійності. В залежності, від обраного показника, надійність слугує якісним та кількісним індикатором цілого комплексу властивостей конструкції. Розглядуючи питання імовірнісного розрахунку болтових з'єднань елементів сталевих силосів, варто приділити увагу питанням, пов'язаним з особливостями даного класу споруд - застосування тонкостінних стрижневих та листових гофрованих елементів, високий рівень завантаженості та врахування найбільш типових будівельних недоліків, що виникають в процесі зведення такої споруди.

Аналіз останніх досліджень і публікацій. Аналітичний розрахунок болтових з'єднань металевих конструкцій наводиться в класичних довідниках курсу металевих конструкцій [1, 2], регламентується нормативним документом [3], а також активно досліджується сучасними науковцями, залежно від напрямку обраних досліджень [4-9]. Традиційно питання імовірнісного розрахунку тяжіють до наукової сфери і залишаються менш вивченими, що безумовно викликано складністю математичних перетворень та великим обсягом теоретичних знань в області теорії імовірностей та математичної статистики. Вирішення задач оцінки надійності вузлів сталевих конструкцій, в тому числі болтових з'єднань, було розпочато в авторських роботах [10-12].

Актуальність та постановка проблеми. В практиці проєктування вузлів тонкостінних конструкцій сталевих силосів, широкого розповсюдження набули болтові 3'єднання елементів. В попередніх дослідженнях було визначено, що проєктна надійність таких стиків відрізняється від фактичних показників їх безвідмовної роботи [11-12]. Джерелом цього $є$ ряд об'єктивних причин, до числа яких можна віднести недоліки монтажних операцій неправильна затяжка болтів чи використання кріпильних елементів непроєктного класу міцності. Дані особливості виходять за рамки вказівок нормативних документів, та, відповідно, оминаються увагою в процесі інженерного розрахунку. Так само як і величини запасу, невідомими лишаються рівні надійності болтових з'єднань виконаних з урахуванням 
монтажних недоліків. Їх оцінка $є$ важливою задачею, що вимагає всебічного розгляду та детального наукового аналізу. Важливим моментом $є$ також дослідження зміни рівня надійності, залежності від впливу «шкідливого» чинника при деякому кількісному вираженні даного фактору.

Мета та завдання. Основною метою даного дослідження є практичний імовірнісний розрахунок квазіоднорідного болтового з'єднання тонкостінних елементів корпусу сталевого силосу. Неоднорідність такого вузла обумовлена присутністю в з'єднанні листів змінної кількості болтів непроєктного класу міцності.

Методи дослідження Розрахунок виконується з використанням теорії імовірностей та математичної статистики на базі загальних методів теорії надійності будівельних конструкцій.

Основними конструктивними елементами корпусу сталевих силосів $є$ тонкостінні елементи листових гофрованих панелей та вертикальних ребер жорсткості, які з'єднуються між собою за допомогою болтових з'єднань, що виконуються з зазором та попереднім затягуванням. Загальна концепція імовірнісного розрахунку такого з'єднання буде грунтуватися на використанні імітаційної процедури Монте-Карло для вибірок великого об'єму нормованих випадкових величин узагальненого зусилля $\gamma_{S, i}$ і узагальненої несучої здатності $\gamma_{R, i}$ з заданими законами розподілу [10]. Для критичного фактору основного металу листів корпусу силосу, справедливим буде відношення

$$
K_{R, i}=\frac{m_{S}}{m_{R}} \cdot \frac{1+\gamma_{S, i} V_{S}}{1+\gamma_{R, i} V_{R}}=m_{K} \cdot \gamma_{K, i},
$$

де $m_{S}$ і $m_{R}$ - математичні очікування випадкових величин міцності $\tilde{R}$ та зусилля $\tilde{S} ; V_{R}$ і $V_{S}$ - коефіцієнти варіації міцності та навантаження; $m_{K}$ - математичне очікування критичного фактору.

У проєктному випадку однорідного болтового з’єднання, коли всі болти системи є елементами однієї вибірки, коефіцієнт критичного фактору металу болтів виражається за наступним виразом [11]

$$
\begin{gathered}
\tilde{K}_{b, i}=\frac{\tilde{S}_{i}}{\tilde{R}_{b s, i} \cdot A_{b} \cdot n}=m_{b} \cdot \frac{1+V_{S} \tilde{\gamma}_{S, i}}{1+V_{b s} \tilde{\gamma}_{b s, i}}, \\
m_{b}=\frac{1,273}{d_{b}^{2} \cdot n} \cdot \frac{m_{S}}{m_{b s}},
\end{gathered}
$$

де $\tilde{R}_{b s, i}$ - випадкова величина міцності одного болта на зріз; $A_{b}-$ значення площі болтів; $d_{b}$ - діаметр болта; $n$ - кількість елементів (болтів) вибірки; $m_{S}$ і $m_{b s}$ та $V_{S}$ і $V_{b s}-$ відповідно значення математичних очікувань та коефіцієнтів варіації випадкових величин $\tilde{S}_{i}$ і $\tilde{R}_{b s, i}$; $\tilde{\gamma}_{b s, i}-$ значення нормованої випадкової величини міцності болта; $\tilde{\gamma}_{S, i}-$ значення нормованої випадкової величини максимумів зовнішнього зусилля, яке діє на з'єднання.

Формула (3) відповідає одночасній відмові всіх болтів 3'єднання при перевищенні випадковим зусиллям $\tilde{S}_{i}$ випадково рівня несучої здатності з'єднання $\tilde{R}_{b s} \cdot A_{b} \cdot n$. Відповідно надійність всього з'єднання визначається виключно статистичними характеристиками міцності одного болта, їх кількістю та імовірнісними характеристиками навантаження.

Для квазіоднорідного болтового з'єднання, коли болти з'єднання складаються 3 двох незалежних вибірок, використання виразів (2) і (3) буде справедливим лише для випадків, коли коефіцієнт критичного фактору $\tilde{K}_{b, i}<1,0$, тобто до настання відмови

$$
\tilde{K}_{b, i}=\frac{\tilde{S}_{i}}{A_{b} \cdot\left(\tilde{R}_{b s 1, i} \cdot n_{1}+\tilde{R}_{b s 2, i} \cdot n_{2}\right)} .
$$


В разі руйнування з'єднання відбувається перевищення критичним фактором одиничного рівня. Даний процес може реалізовуватися за різним схемами, кожна 3 яких має бути розглянута при обчисленні випадкової величини критичного фактору. Для з'єднання 3 двох болтів, випадкова міцність яких в просторі зусиль становить відповідно $\tilde{S}_{01}$ i $\tilde{S}_{02}$, надійність з'єднання буде забезпечена, якщо для $i$-го елементу вибірки виконується ряд наступних вимог:

1) при значенні зусилля $\tilde{S}_{i}$ міцність обох болтів забезпечена;

2) зусилля $\tilde{S}_{i}$ викликає відмову другого болта, а перший продовжує виконувати свої функції;

3) зусилля $\tilde{S}_{i}$ викликає відмову першого болта, другий продовжує виконувати свої функції;

4) міцність обох болів вичерпана одночасно.

Відповідно, формула для коефіцієнт критичного фактору набуде вигляду сукупності умов [11]

$$
\tilde{K}_{b, i}=\mid \begin{array}{cllll}
\tilde{S}_{i} /\left(\tilde{S}_{01, i}+\tilde{S}_{02, i}\right), & \text { if } & \tilde{S}_{i} / \tilde{S}_{01, i}<2 & \wedge & \tilde{S}_{i} / \tilde{S}_{02, i}<2 ; \\
\tilde{S}_{i} / \tilde{S}_{01, i}, & \text { if } & \tilde{S}_{i} / \tilde{S}_{01, i}<2 & \wedge & \tilde{S}_{i} / \tilde{S}_{02, i} \geq 2 ; \\
\tilde{S}_{i} / \tilde{S}_{02, i}, & \text { if } & \tilde{S}_{i} / \tilde{S}_{01, i} \geq 2 & \wedge & \tilde{S}_{i} / \tilde{S}_{02, i}<2 \\
\tilde{S}_{i} /\left(\tilde{S}_{01, i}+\tilde{S}_{02, i}\right) & \text { if } & \tilde{S}_{i} / \tilde{S}_{01, i} \geq 2 & \wedge & \tilde{S}_{i} / \tilde{S}_{02, i} \geq 2 .
\end{array}
$$

Основний матеріал і результати. Відповідно до описаного підходу, був виконаний практичний розрахунок стику двох панелей корпусу циліндричної ємності зберігання, на яку діє розрахункове зусилля величиною $S_{p}=800$ кН. Коефіцієнт варіації зусилля приймаємо рівним $V_{S}=0,2$ та знаходимо його математичне очікування $m_{S}$, яке пов'язане 3 розрахунковим значенням $S_{p}$ співвідношенням

$$
m_{S}=\frac{S_{p}}{1+2 \cdot V_{S}} \approx 570 \kappa \mathrm{H} .
$$

3 досвіду проєктування відомо, що при конструюванні стику листів корпусу та покрівлі силосної ємності найчастіше застосовуються болти М10 двох класів міцності 5.8 та 8.8. Досить часто в процесі монтажу припускаються помилки та виконують встановлення в 3'єднанні стика, який розрахований на болти 8.8, болтів 3 меншим класом міцності.

Розрахункові значення міцності болтів на зріз відповідно становлять $R_{b s 1}=32 \mathrm{\kappa H} / \mathrm{cm}^{2}$ (клас 8.8) і $R_{b s 2}=21 \mathrm{\kappa H} / \mathrm{cm}^{2}$ (клас 5.8) при коефіцієнтах варіації $V_{b s 1}=0,07$ і $V_{b s 2}=0,1$.

Математичні очікування міцності визначимо наступним чином

$$
m_{b s 1}=\frac{R_{b s 1}}{1-3 V_{b s 1}}=42,1 \kappa \mathrm{H} / \mathrm{cm}^{2}, \quad m_{b s 2}=\frac{R_{b s 2}}{1-3 V_{b s 2}}=30 \mathrm{\kappa H} / \mathrm{cm}^{2} .
$$

Розрахуємо необхідну кількість болтів класу міцності 8.8 на зріз при дії розрахункового зусилля $S_{p}=800$ кН. Для цього скористаємося формулою (16.12) ДБН [3] при одиничних коефіцієнтах $\gamma_{b}, \gamma_{c}$ i $\gamma_{n}$

$$
n=1,273 \frac{S_{p}}{R_{b s 1} d_{b}^{2}}=1,273 \cdot 800 /(32 \cdot 1) \approx 32 \text { болта. }
$$

Виконаємо імовірнісний розрахунок болтового з'єднання за умови, що в загальній кількості болтів $n=32$ виявилось $n_{2}=1 \div 31$ болтів класу міцності 5.8 .

Результати розрахунку, представлені у вигляді кривих критичного фактору на рис. 1, побудованих для різних значень кількості непроєктних болтів. Для графічного 
представлення графіків надійності застосована координатна площина, на якій по осі абсцис відкладається аргумент подвійного експоненціального розподілу Гумбеля [10]

$$
y=-\ln \left[-\ln \left(F_{\gamma}\right)\right],
$$

де $F_{\gamma}$ - імовірність безвідмовної роботи

$$
F_{\gamma}=\exp \left[-\exp \left(\frac{\alpha_{B}-\sqrt{\alpha_{B}^{2}-4 \alpha_{A}^{2}\left(1-\alpha_{C} V_{S}-1 / m_{b}\right)}}{2 \alpha_{A}}\right)\right],
$$

де $\alpha_{A}, \alpha_{B}$ и $\alpha_{C}$ - безрозмірні коефіцієнти, які враховують вплив коефіцієнту варіації несучої здатності та максимумів випадкового навантаження. Їх значення покладаються рівними: для розподілу навантаження за нормальним законом розподілу $\alpha_{A} \approx-0,02$, $\alpha_{B} \approx 0,65, \alpha_{C} \approx 0,18$ та для подвійного експоненціального закону Гумбеля $\alpha_{A} \approx 0, \alpha_{B} \approx 0,84$, $\alpha_{C} \approx 0,57$.

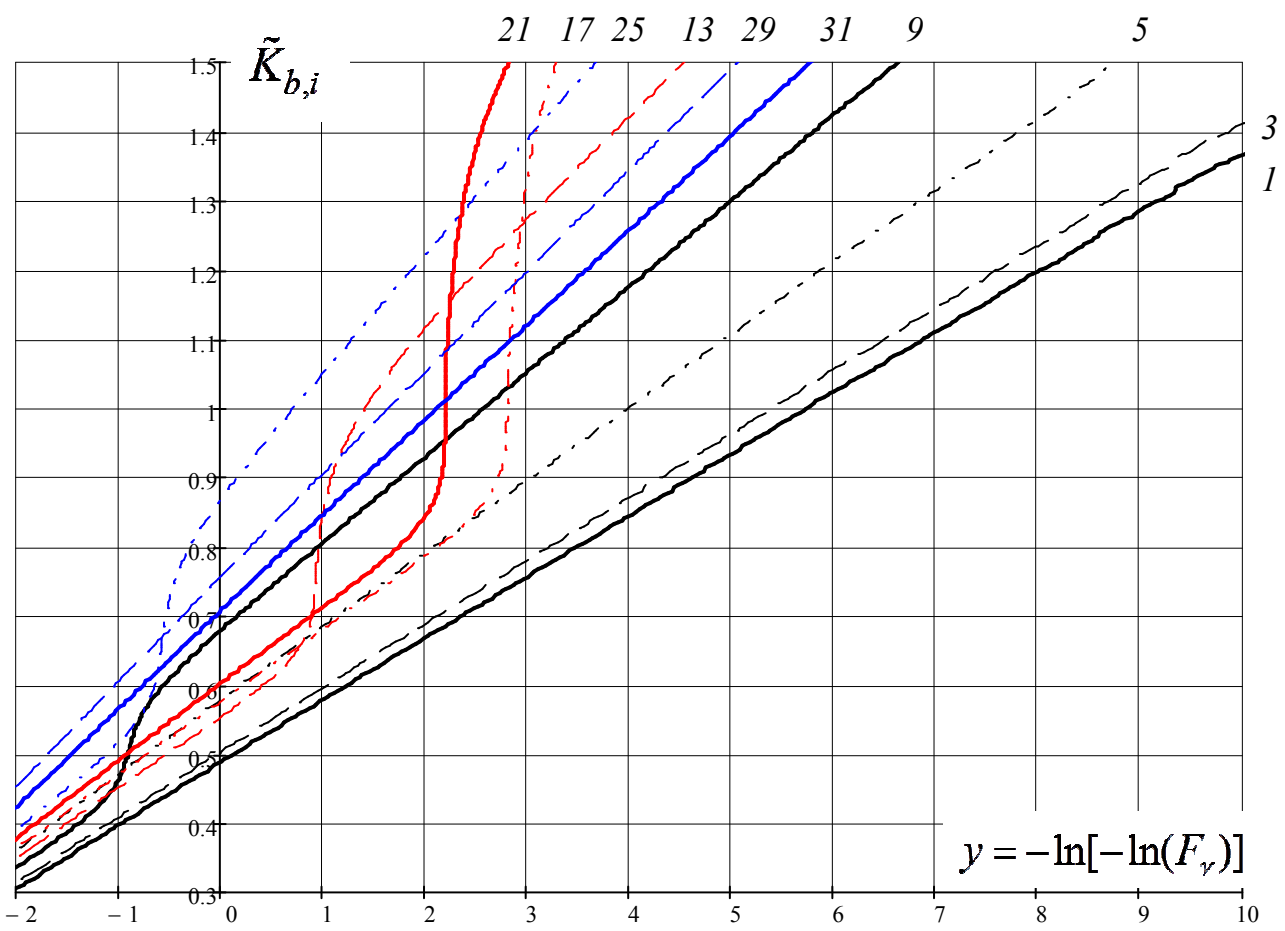

Рис. 1. Імовірності безвідмовної роботи багатоболтового з’єднання при використанні декількох болтів з меншим класом міцності

Аналізуючи графіки (рис. 1), цілком логічно виявлено, що імовірність відмови з'єднання при «заміні» проєктного класу міцності болтів іншим знижується. Проте цікаво дослідити характер даного зниження.

Отже, при кількості непроєктних болтів $1<n_{2}<5$ імовірність безвідмовної роботи знижується монотонно, а криві критичного фактору не мають яскраво вираженої точки перегину. Положення даної точки можливо приблизно прослідкувати лише при $n_{2}=9$. Відповідно подальше збільшення кількості замінених болтів призводить до зниження імовірності безвідмовної роботи і більш чіткого вираження точки перегину

При $n_{2}>13$ спостерігається досить цікаве явище - при збільшенні кількості болтів «заміни», імовірність безвідмовної роботи починає збільшуватися. Дана тенденція триває до значень $n_{2}=19$, після чого можливо спостерігати різке падіння.

Мінімум імовірності безвідмовної роботи реалізується при співвідношенні болтів $n_{1} \approx 7$ та $n_{2} \approx 25$, і в подальшому спостерігається збільшення надійності з’єднання. 
Таким чином ми можемо відмітити, що імовірність безвідмовної роботи при кількості болтів «заміни» $n_{2}=21$ i $n_{2}=31$, а також $n_{2}=9$ i $n_{2}=17$ будуть приблизно рівні. Спробуємо надати логічне пояснення даному явищу.

При застосуванні болтів меншої міцності з’єднання здебільшого втрачає міцність та руйнується. Імовірність даного руйнування буде монотонно збільшуватися при збільшенні кількості болтів «заміни», при цьому в першу чергу відмовлять саме вони. При подальшому зростанні кількості непроєктних болтів, певна річ також відбудеться руйнування з'єднання, проте механізм руйнування може бути будь-який - або по основним болтам, або по болтам «заміни». Дани факт буде залежати від імовірнісних властивостей навантаження і міцності.

Висновки дослідження. Таким чином на основі авторської методики імовірнісного розрахунку багатоболтових з'єднань корпусу циліндричних ємностей, утворених із болтів однакового та різних класів міцності, виконано практичний розрахунок надійності квазіоднорідних болтових з'єднань листів тонкостінних конструкцій сталевих силосів при варіюванні кількості непроєктних кріпильних елементів. Результати зміни імовірності безвідмовної роботи та характер зміни надійності проілюстровано в графічному представленні у вигляді сукупності кривих критичного фактору на критичній імовірнісній шкалі. Показано, що при незначній кількості болтів «заміни» саме вони виступають основною причиною відмови з'єднання, проте при зростанні кількості непроєктних болтів механізм руйнування буде залежати від імовірнісного обгрунтування навантаження i міцності.

\section{Література}

1. Анурьев В.И. Справочник конструктора машиностроителя : в 3 т. Т. 1. - М.: Машиностроение, 2001. - 920 с.

2. Орлов П.П. Основы конструирования: в 3 т. Т.2. - М.: Машиностроение, 1977. - 574 c.

3. ДБН В.2.6-198:2014. Сталеві конструкції. Норми проектування. - [Чинний від 201501-01]. - К. : Мінрегіон України, 2014. - 199 с. - (Державні будівельні норми України).

4. Maggi Y.I. Parametric analysis of steel bolted end plate connections using finite element modeling / Y.I.Maggi, R.M.Gonçalves, R.T.Leon, L.F.L.Ribeiro // Journal of Constructional Steel Research. - Vol. 61, № 5. - 2005. - P. 689-708.

5. Liu F. Probabilistic bolt load distribution analysis of composite single-lap multi-bolt joints considering random bolt-hole clearances and tightening torques / F. Liu, M. Shan, L. Zhao, J. Zhang. - Composite Structures. - Vol. 194, №15. - 2018. - C. 12-20

6. Elliott M.D. Behaviour and strength of bolted connections failing in shear / M.D. Elliott, L. H.Teh, A. Ahmed // Journal of Constructional Steel Research. - Vol. 153. - 2019. - P. 320-329.

7. Farahmand B. Fracture mechanics of metals, composites, welds, and bolted joints: application of LEFM, EPFM, and FMDM theory / B. Farahmand. - Pringer Science+Business Media, 2001. $-408 \mathrm{p}$.

8. Kim T.S. Experimental investigation on strength and curling influence of bolted connections in thin-walled carbon steel / T.S. Kim, J.H. Yoo, C.W. Roeder // Thin-Walled Structures. - Vol. 91. - 2015. - P.1-12. https://doi.org/10.1016/j.tws.2015.01.016

9. Yu C. Bearing strength of cold-formed steel bolted connections with a gap / C. Yu, M. Panyanouvong //Thin-Walled Structures. - Vol. 67. - 2013. - P. 110-115

10. Махінько Н.О. Імовірнісне представлення коефіцієнта критичного фактору в задачах надійності будівельних конструкцій / Н.О. Махінько // Наука та будівництво. - К. : НДІБК, 2019. - № 2. - С. 56-61.

11. Пічугін С.Ф. Оцінка надійності багатоболтових з'єднань стінки силосної ємності / С.Ф. Пічугін, Н.О. Махінько // Building Innovations - 2019 : зб. наук. пр. за матеріалами II Міжнар. укр.-азерб. конф., 23 - 24 трав. 2019 р. - Полтава : ПолтНТУ, 2019. - С. 176-178. 
12. Махінько Н.О. До розрахунку надійності елементів сталевих ємностей зберігання / Н.О. Махінько // Вісник Придніпровської державної академії будівництва та архітектури. Дніпро : ПДАБА, 2018. - Вип. 6 (247-248). - С. 71-76.

\title{
References
}

[1] V. Anurev, Spravochnik konstruktora mashinostroitelia. Moscow: Mashinostroenie, 2001.

[2] P. Orlov, Osnovy konstruirovaniia. Moscow: Mashinostroenie, 1977.

[3] DBN V.2.6-198:2014. Stalevi konstruktsii. Normy proektuvannia. Kyiv, Minrehion Ukrainy, 2014.

[4] Y. Maggi, R. Gonçalves, R. Leon and L. Ribeiro, "Parametric analysis of steel bolted end plate connections using finite element modeling", in Journal of Constructional Steel Research, Vol. 61(5). Elsevier, 2005, pp. 689-708.

[5] F. Liu, M. Shan, L. Zhao and J. Zhang, "Probabilistic bolt load distribution analysis of composite single-lap multi-bolt joints considering random bolt-hole clearances and tightening torques", in Composite Structures, Vol. 194 (15). Elsevier, 2018, pp. 12-20.

[6] M.D. Elliott, L.H. Teh and A. Ahmed, "Behaviour and strength of bolted connections failing in shear", in Journal of Constructional Steel Research, Vol. 153. Elsevier, 2019, pp. 320-329.

[7] B. Farahmand, Fracture mechanics of metals, composites, welds, and bolted joints: application of LEFM, EPFM, and FMDM theory. Springer, 2001.

[8] T.S. Kim, J.H. Yoo and C.W. Roeder, "Experimental investigation on strength and curling influence of bolted connections in thin-walled carbon steel", in Thin-Walled Structures, Vol. 9. Elsevier, 2015, pp. 1-12.

[9] C. Yu and M. Panyanouvong, "Bearing strength of cold-formed steel bolted connections with a gap", in Thin-Walled Structures, Vol. 67. Elsevier,, 2013, pp. 110-115.

[10] N.O. Makhinko, "Imovirnisne predstavlennia koefitsiienta krytychnoho faktoru v zadachakh nadiinosti budivelnykh konstruktsii," in Nauka ta budivnytstvo, Vol. 2 (20). Kyiv, Masterknig, 2019, pp. 56-61.

[11]S. Pichugin and N.O. Makhinko, " Otsinka nadiinosti bahatoboltovykh ziednan stinky sylosnoi yemnosti " in Zb. mat. tu II Mizhnar. ukr.-azerb. konf, Poltava, PoltNTU, 2019, pp. 176-178.

[12]. N.O. Makhinko, "Do rozrakhunku nadiinosti elementiv stalevykh yemnostei zberihannia", in Visnyk PDABA, Vol. 6 (247-248). Dnipro, PDABA, 2018, pp. 71-76.

\section{ПРАКТИЧЕСКИЕ ПОДХОДЫ К РАСЧЕТУ НАДЕЖНОСТИ МНОГОБОЛТОВЫХ СОЕДИНЕНИЙ ЛИСТОВ КОРПУСА СИЛОСНЫХ ЕМКОСТЕЙ}

\author{
Махинько А.В., Д.т.н., с.н.с. \\ TOВ «Этуаль» \\ pasargada1981@gmail.com, ORCID 0000-0002-9147-7087 \\ Махинько Н.А., к.Т.н. \\ Национальный авиационный университет \\ pasargada1985@gmail.com, ORCID 0000-0001-8120-6374
}

\begin{abstract}
Аннотация. В представленной статье рассматриваются вопросы практического расчета вероятности безотказной работы квазиоднородных болтовых соединений листов корпуса стальных силосов. Неоднородность стыков тонколистовых конструкций силоса может быть вызвана рядом причин, наиболее распространенными из которых являются ошибки монтажа, например, присутствие в соединение болтов непроектного класса прочности. Такой дефект будет вызывать увеличение риска отказа, количественно определить величину которого, согласно существующим инженерным методикам или указаниям нормативных документов не представляется возможным. Более логичным в этом направлении является использование вероятностных методов расчета, которые во-первых дают более оправданный экономический результат, а во-вторых, в зависимости от принятого показателя, могут являться качественной
\end{abstract}


и количественной характеристикой любого параметра. В рамках данной задачи, расчет надежности соединения выполнялся путем определения случайной величины коэффициента критического фактора. Значение данного параметра принималось равным соотношению случайной величины обобщенного усилия к случайной величине несущей способности стыка. В представленном примере болтового соединения тонколистовых конструкций силоса, коэффициент критического фактора определялся согласно авторской методики из системы условий, при которых соблюдается надежность неоднородного соединения. Также в статье исследована зависимость уровня надежности соединения при варьировании количества непроектных болтов. Результаты изменения вероятности безотказной работы и характер поведения графиков надежности проиллюстрировано на графиках в виде совокупности кривых критического фактора на критической вероятностной шкале. Выбор данной визуализации основывается на простоте и наглядности представления полученных результатов. В ходе исследования показано, что при незначительном количестве болтов «замены» именно они выступают основной причиной отказа соединения, однако при росте количества непроектных болтов механизм разрушения будет зависеть от вероятностного обоснования нагрузки и прочности.

Ключевые слова: Вероятностный расчет, болтовое соединение, силос, надежность, вероятность безотказной работы, коэффициент критического фактора.

\title{
PRACTICAL APPROACHES TO CALCULATING THE RELIABILITY OF MULTIPLE- BOLT JOINTS OF THE SILO BODY SHEETS
}

Makhinko A.V., Doctor of Engineering., Senior Scientist, ETUAL LLC, pasargada1981@gmail.com, ORCID 0000-0002-9147-7087 Makhinko N.O., PhD, Assistant Proffesor, National Aviation University pasargada1985@gmail.com, ORCID 0000-0001-8120-6374

\begin{abstract}
This article discusses the issues of practical probability calculation of failure-free operation of quasihomogeneous bolted joints of steel silo body sheets. The heterogeneity of the joints of silo thin-sheet structures can be caused by a number of reasons, the most common of which are installation errors, for example, the presence of a beyond-design strength class in the bolt joint. Such a defect will cause an increase in the risk of failure, to quantify the value of which is not possible, according to existing engineering methods or guidelines of regulatory documents. It is more logical in this direction to use probabilistic methods of calculation, which, firstly, give a more justified economic result, and secondly, depending on the adopted indicator, can be a qualitative and quantitative characteristic of any parameter. As part of this problem, the reliability calculation of the joint was performed by determining a random value of the critical variable coefficient. The value of this parameter was taken equal to the ratio of the random value of the generalized stress to the random value of the joint bearing capacity. In the presented example of a bolted joint of thinsheet silo structures, the critical variable coefficient was determined according to the author's technique from a system of conditions under which the reliability of an inhomogeneous joint is observed. The article also investigated the dependence of the level of joint reliability when varying the number of beyond-design bolts. The results of changes in the probability of failure-free operation and the behavior of the reliability graphs are illustrated in the graphs as a set of critical variable curves on a critical probability scale. The choice of this visualization is based on the simplicity and clarity of the presentation of the results received. The study showed that with a small number of "replacement" bolts, they are the main reason for the failure of the joint; however, with an increase in the number of beyond-design bolts, the fracture mechanism will depend on the probabilistic justification of the load and strength.
\end{abstract}

Keywords. Stochastic calculation, bolted joints, silo, reliability, probability of the troublefree work, coefficient of the critical factor. 


\title{
ОЦЕНКА НЕСУЩЕЙ СПОСОБНОСТИ ОПОРНЫХ УЗЛОВ ДЕРЕВЯННЫХ КЛЕЕННЫХ БАЛОК С ПОДРЕЗКАМИ
}

\author{
Найчук А.Я. д.т.н., проф. \\ atnya@yandex.by, \\ УО «Брестский государственный технический университет»
}

\begin{abstract}
Аннотация. Одним из методов уменьшения строительной высоты покрытия или перекрытия с использованием клееных деревянных балок, а также соединения по их длине является выполнение подрезок в опорных узлах. Такой же метод используют при проектировании балочных перекрытий, где опирание второстепенных балок на главные осуществляется в заранее выбранные гнезда как в главных так и второстепенных балках. Что же касается расчета таких узлов, то в нормативных документах приведена лишь методика расчета для случая, кода в опорных узлах подрезка выполняется со скосом, или же устанавливаются жесткие ограничения относительно глубины подрезки балки без скоса со стороны растянутой зоны по отношению к ее высоте. Кроме того в ряде нормативных документов рекомендуется в зоне подрезки устанавливать вклеенные или ввинченные стержни, но каких-либо данных по их расчету не приводится. Поэтому целью данных исследований являлось разработать модель, позволяющую оценить несущую способность опорных узлов деревянных клееных балок с подрезками различной глубины по высоте поперечного сечения, а также элементами усиления в виде вклеенными перпендикулярно волокнам стальных стержней. Для достижения поставленной цели были выполнены экспериментально-теоретические исследования фрагментов опорных узлов балок с использованием методов механики разрушения. Теоретические исследования выполнялись с использованием программы в которой реализован метод конечных элементов и реализована процедура определения коэффициентов интенсивности напряжений. В результате численных исследований, по предложенной методике, базирующейся на использовании критерия разрушения, определены закономерности изменения несущей способности в зависимости от отношения глубины врезки и диаметра вклеенных арматурных стержней. В результате испытаний натурных фрагментов опорных узлов балок с подрезками подтверждена достоверность принятой методики численных исследований и разработанной модели определения несущей способности узлов. На основе полученных результатов исследований установлено, что наличие подрезки в опорных узлах деревянных клееных балок со стороны растянутой кромки существенно снижает их несущую способность, а установка вклеенных поперек волокон древесины двух арматурных стальных стержней диаметром от 16 мм до 20 мм на расстоянии не менее трех диаметров от вертикальной грани подрезки повышает несущую способность узла в 8 - 10 раз, по сравнению с узлами без арматурных стержней.
\end{abstract}

Ключевые слова: вклеенный стержень, деревянная балка, коэффициент интенсивности напряжений, разрушающая нагрузка, сопротивление, несущая способность.

Введение. При проектировании зданий и сооружений с применением деревянных клееных балок очень часто встает вопрос об уменьшении строительной высоты покрытия или перекрытия. Одним из таких методов является уменьшение высоты поперечного сечения балок на опорах путем выполнения подрезки как со скосом, так и в виде прямоугольного углубления со стороны растянутой зоны балки (рис.1). Кроме того, такое конструктивное решение применяется в стыках многопролетных деревянных клееных балок.

Общеизвестно, что наличие подрезок в опорных зонах балок приводит к концентрации напряжений вследствие резкого изменения поперечного сечения, что существенным образом снижает их несущую способность. 
В нормах [1, 2] приведены методики расчета опорных участков балок виде прямоугольного углублений со скосами. Что же касается подрезок опорных участков балок без скосов, то такие случаи не рассматриваются, поскольку наличие таких подрезок существенным образом снижает их несущую способность. Следует отметить, что в [3, 4] наличие подрезки со скосом допускается выполнять для балок с цельной древесины, т.е. в балках незначительных пролетов, что чаще всего это относится к прогонам. Согласно [3, 4] глубина подрезки $a$ не должна превышать $0,25 h$, а длина $c$ опорной площадки не должна быть больше $h$ при длине скоса $c_{1} \geq 2 a$ (рис. 1) если

$$
\frac{Q}{b h}<0,4 \text { МПа, }
$$

где $Q$ - опорная реакция от расчетной нагрузки; $b$ и $h$ - ширина и высота поперечного сечения балки.

a)

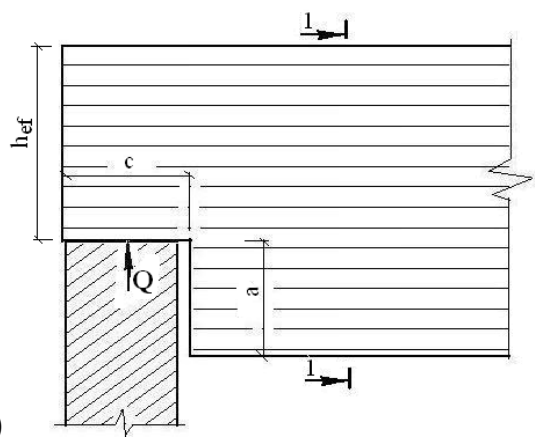

б)

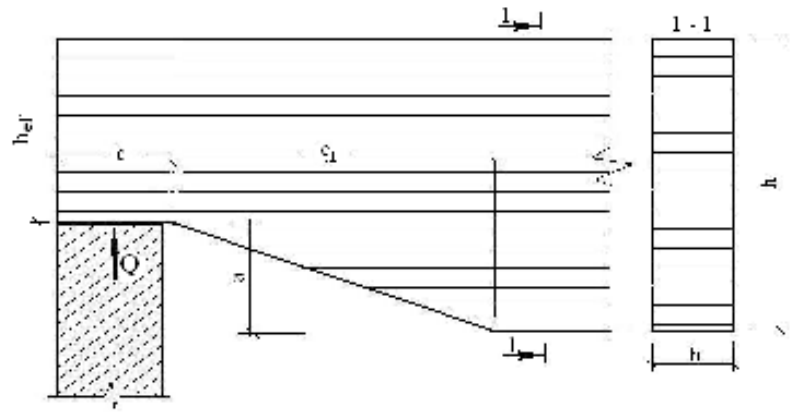

Рис. 1. Схема опорного узла балки с подрезкой

а) - без скоса; б) - со скосом

Следует отметить, что для деревянных балок с подрезками на опорах несущая способность ограничивается не сопротивлением сечения изгибу, расположенного в зоне максимального изгибающего момента или скалыванию вдоль волокон в сечениях опорных зон, а сопротивлением сечения в зоне подрезки. Для повышения несущей способности опорных узлов балок с подрезками могут использоваться накладки (деревянные, либо фанерные), наклеенные на боковые поверхности, стяжные болты, металлические стержни периодического профиля, вклеенные в пазы или ввинченные перпендикулярно волокнам древесины стальные винты. Применение накладок или металлических стержней, вклеенных в пазы, выбранные на боковых поверхностях, ограничивается температурно-влажностным режимом эксплуатации конструкций. Это вызвано тем, что согласно [5 - 7], поверхностные слои древесины в поперечных сечениях клееных балок, характеризующихся значительной высотой по сравнению с балками из цельной древесины, при периодическом увлажнении, приводящему к появлению дополнительных усилий в клеевом соединении, а иногда и к нарушению его контакта между накладкой или стержнем, стесняющим поперечные деформации. Установка стяжных болтов также малоэффективна, поскольку древесина обладает значительной ползучестью поперек волокон, и такое конструктивное решение можно рассматривать лишь как аварийную связь. Для винтов или стержней, вклеенных в высверленные поперек волокон древесины отверстия, этот недостаток исключен. Кроме того, здесь стержни защищены от действия химически агрессивной среды и быстрого нагрева при пожаре. Учитывая отсутствие в нормативных документах методики по оценке несущей способности опорных узлов балок с подрезками без скосов, а также узлов усиленных вклеенными или ввинченными стержнями, нами были проведены их экспериментально-теоретические исследования.

Целью исследований являлось определение закономерностей изменения несущей способности опорных узлов балок с подрезками без скосов в зависимости от отношения 
глубины $a$ подрезки к высоте $h$ поперечного сечения балки (рис.1) и диаметра $d$ вклеенных или ввинченных стальных стержней, как элементов усиления.

Методика исследований. Теоретические исследования узлов проводились численным методом по программе [8] в которой реализован метод конечных элементов (МКЭ) с определением параметров механики разрушения таких как: коэффициенты интенсивности (КИН) $K_{I}$ и $K_{I I}$, а также контурных интегралов $J_{x}$ и $J_{y}$.

Общеизвестно, что в зоне резкого изменения поперечного сечения любого нагруженного элемента имеет место сложное неоднородное напряженное состояние (концентрация напряжений), где для проверки прочности материала в указанных зонах чаще всего используют критерии прочности. Следует отметить, что значения компонент напряжений в указанных зонах, определенные по МКЭ, зависят от размеров КЭ. Поэтому и несущая способность элемента, определенная исходя из проверки того или иного критерия прочности, будет зависеть от принятого размера КЭ. Учитывая данный недостаток нами была разработана методика определения несущей способности опорных узлов балок с подрезками, базирующаяся на использовании не критериев прочности, а критериев разрушения, компонентами которых являлись значения коэффициентов интенсивности напряжений $K_{I}$ и $K_{I I}$ для соответствующих длин трещин и значения вязкости разрушения материала (древесины) $K_{I c}$ и $K_{I I c}$. Сущность данной методики заключалась в следующем:

- первоначально для опорного узла балки с подрезкой с соответствующими геометрическими параметрами поперечного сечения (шириной $b$, высотой $h$ ) и глубиной врезки $a$ определялись значения коэффициентов интенсивности напряжений $K_{I}$ и $K_{I I}$ от действия усилия $Q$ при разных значениях длины трещины $l_{i}$ (рис.2);

- для каждого расчетного случая с заданной длиной $l_{i}$ трещины и величиной приложенного усилия $Q$, определялись значения разрушающей нагрузки $Q_{t, i}$, исходя из критерия разрушения [9], по формуле

$$
Q_{t, i}=\frac{Q}{K_{I} / K_{I C}+\left(K_{I I} / K_{I C}\right)^{2}},
$$

$\mathrm{Q}$ - усилие, приложенное в узле (опорная реакция); $K_{I}$ и $K_{I I}-$ КИН в вершине трещины длиной $l_{i} ; K_{I c}$ и $K_{I I c}-$ вязкость разрушения древесины при нормальном отрыве и поперечном сдвиге.

- для каждого отношения глубины врезки $a$ к высоте поперечного сечения $h$ выполнялась аппроксимация значений $Q_{t, i}$ в зависимости от длины $l_{i}$ трещины;

- за разрушающую нагрузку узла $Q_{t}$ принималось значение, полученное из аппроксимирующей зависимости $Q_{t, i}\left(l_{i}\right)$ при длине трещины $l_{i}=0$;

- для определения расчетных значений несущей способности $Q_{d, i}$ узла в выражении (2) использовались расчетные значения вязкости разрушения древесины $K_{d, \text { Ic }}$ и $K_{d, I I c}[10]$.

При проведении численных исследований было рассмотрено две серии узлов: первая серия - узлы балок с подрезкой на опоре и трещиной длиной $l_{i}$; вторая серия - узлы балок с подрезкой на опоре, усиленные вертикально вклеенными в тело древесины арматурными стержнями, и трещиной длиной $l_{i}$ (рис. 2).

a)

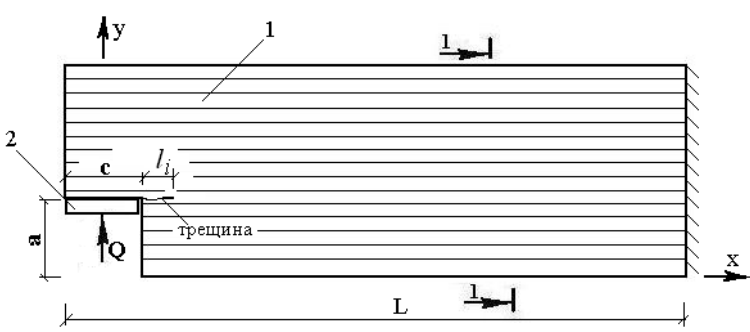

б)

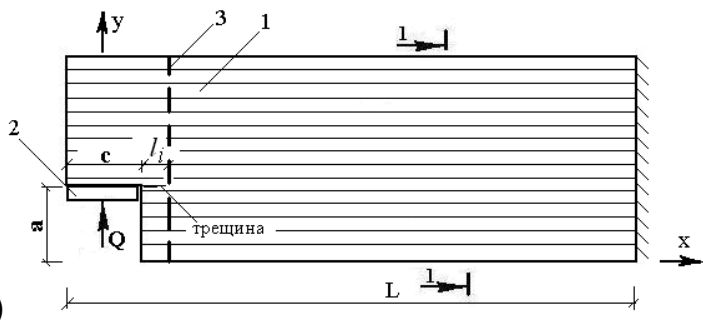

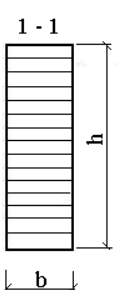

1 - древесина; 2 - стальная пластина; 3 - арматурные стержни

Рис. 2. Расчетные схемы узлов балок с подрезкой на опоре

a) - узел балки с подрезкой на опоре (серия 1); б) - узел балки с подрезкой на опоре, усиленный арматурными стержнями (серия 2) 
Расчетная область узла, граница которой определяется длиной $L$ (рис.2), назначалась в соответствие с [11]. В качестве варьируемых параметров при расчете узлов первой серии принимались: отношение $a / h=0,1 ; 0,2 ; 0,3 ; 0,4$ и 0,5 ; длина трещины $l_{i}=3 ; 5$ и 10 мм; а для узлов второй серии - отношение $a / h=0,1 ; 0,2 ; 0,3 ; 0,4$ и 0,$5 ;$ диаметр арматурных стержней $d$ $=16 ; 18$ и 20 мм (по два стержня), расположенных на расстоянии 60 мм от вертикальной грани подрезки с длиной трещины $l=59$ мм. Во всех расчетных схемах длина опорной площадки $c=150$ мм, высота сечения балки $h=500 \mathrm{Mм}$, a ее толщина $b=140$ мм (рис. 2). Толщина стальной пластины 2 принималась равной 70 мм. Упругие характеристики для стальной пластины 2 и арматурных стержней 3 равнялись: $E_{x}=E_{y}=210000 \mathrm{MПа,} \mu_{x y}=\mu_{y x}=0,3$ и $G_{x y}=81000 \mathrm{MПа,} \mathrm{а} \mathrm{для} \mathrm{древесины}-E_{x}=11000 \mathrm{MПа,} E_{y}=500 \mathrm{MПа,} \mu_{x y}=0,44, \mu_{y x}=0,02$ и $G_{x y}=500$ МПа (рис. 2). Во всех расчетных схемах усилие $Q=70$ кН.

С целью проверки результатов, полученных в процессе численных исследований опорных узлов балок с подрезками, нами были проведены испытания натурных узлов. Всего было изготовлено и испытано 18 узлов трех серий, каждая из которых состояла из 6 образцов. Все узлы изготавливались из клееной древесины. Подразделение узлов на серии осуществлялось в зависимости от отношения $a / h$ и высоты сечения $h$. Каждая серия узлов подразделялась на две группы. В первую группу включались узлы без арматурных стержней, а во вторую - узлы с вклеенными арматурными стержнями. В первую серию У-І включались узлы поперечным сечением $b \times h=140 \times 500$ мм с отношением $a / h=0,4$; во вторую У-ІІ - узлы поперечным сечением $b \times h=140 \times 500$ мм с отношением $a / h=0,5$ и в третью У-ІІІ - узлы поперечным сечением $b \times h=160 \times 910$ мм с отношением $a / h=0,5$ (рис.3).
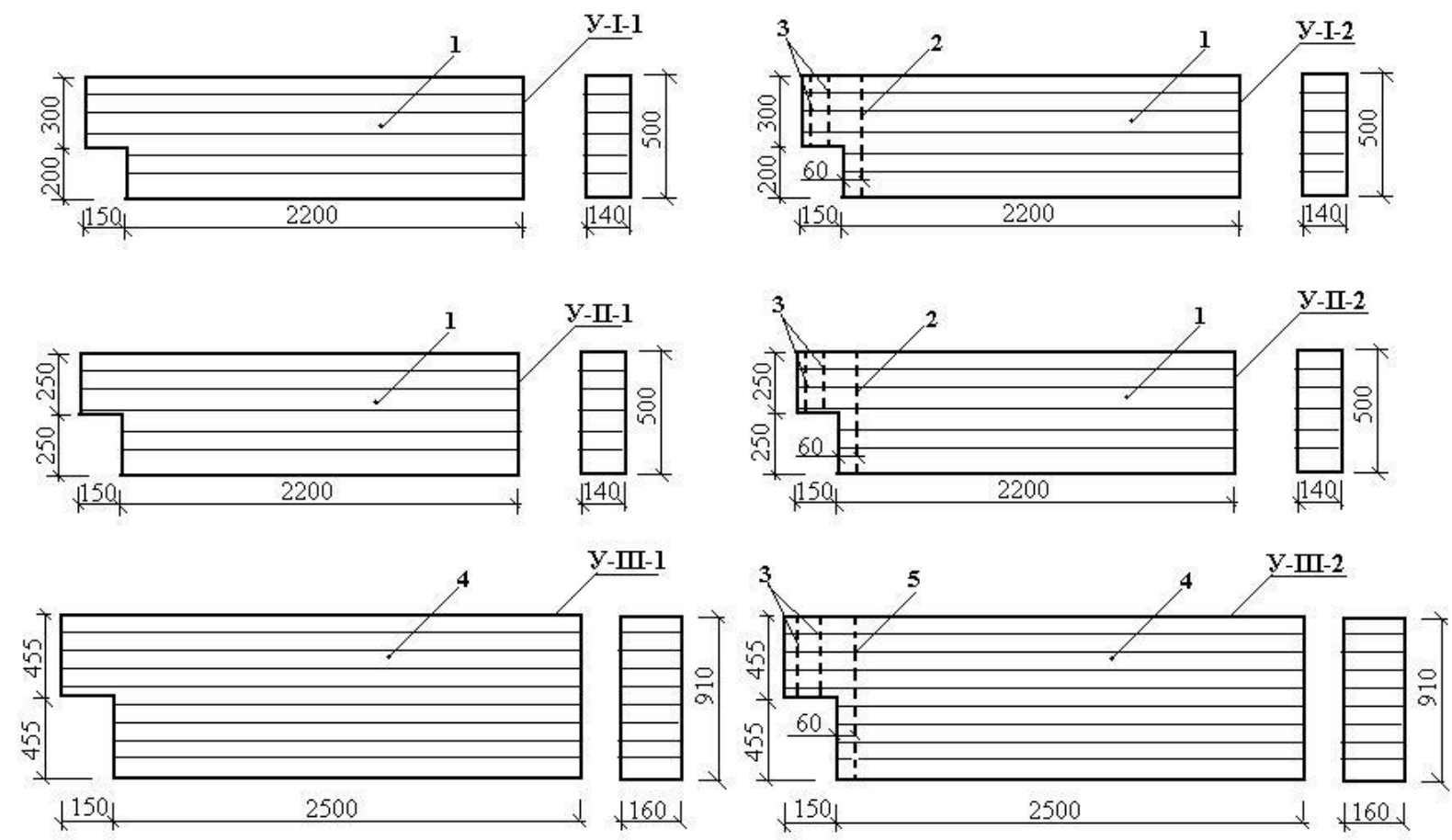

1, 4 - деревянные элементы; 2 - арматурные стержни диаметром 16 мм; 3 - арматурные стержни диаметром 16 мм; 5 - арматурные стержни диаметром 20 мм

Рис. 3. Схемы фрагментов узлов для испытаний

В узлах первой и второй серий второй группы (У-I-2; У-II-2) на расстоянии 60 мм от торца вертикальной грани подрезки было вклеено по два стальных арматурных стержня диаметром 16 мм, а в узлах третьей серии второй группы (У-III-2) по два арматурных стержня диаметром 20 мм (рис.3). Для каждой группы узлов было изготовлено и испытано по три образца. Ввиду недостаточной несущей способности опорных площадок от смятия древесины поперек волокон, они были усилены 4 арматурными стержня 3 (рис. 3) диаметром 16 мм, вклеенными на всю высоту поперечного сечения в опорной части. 
Испытание узлов проводилось по балочной схеме. Нагружения образцов осуществлялись с помощью гидравлических домкратов ступенями. На каждой ступени нагружения осуществлялась выдержка в течение 10 мин. Посредством индикаторов часового типа, установленных на боковых гранях образцов в зоне предполагаемого образования трещины, измерялись деформации древесины поперек волокон, а при образовании трещины - раскрытие ее берегов. По результатам испытаний определялись два значения нагрузки: первая $Q_{t 1}$ - значение нагрузки соответствующее началу образования продольной трещины; вторая $Q_{t 2}$ - значение нагрузки, при котором происходило полное разрушение узла.

Разрушающая нагрузка определялась из диаграмм деформирования древесины поперек волокон в зоне образования трещины. В образцах без арматурных стержней за разрушающую нагрузку принималось значение $Q_{t 1}$, при котором на диаграмме разностей деформаций наблюдалось их резкое увеличение. В узлах с арматурными стержнями (У-I-2, У-II-2 и У-III-2) за разрушающую нагрузку принималось значение $Q_{t 2}$, при котором происходило разрушение образца, характеризующееся развитием трещины за арматурными стержнями и резким падением нагрузки (растяжение поперек и скалывание древесины по длине образца). Экспериментальное значение величины несущей способности испытанных узлов определялась в соответствии с рекомендациями [12].

Результаты численных исследований. В результате выполненных расчетов были определены КИН $K_{I}$ и $K_{I I}$, значения которых приведены в табл.1 и табл.2.

Таблица 1 - Результаты численных исследований опорных узлов балок с подрезкой поперечным сечением $b \times h=140 \times 500$ мм без арматурных стержней от действие усилия $Q=70 \kappa \mathrm{H}$

\begin{tabular}{|c|c|c|c|c|c|}
\hline $\begin{array}{c}\text { Отношение } \\
\mathrm{a} / \mathrm{h}\end{array}$ & $\begin{array}{c}\text { Длина } \\
\text { трещины } 1_{i}, \text { мм }\end{array}$ & $\begin{array}{l}\text { КИН } K_{I} \text { в } \\
\text { МПа }{ }^{1 / 2}\end{array}$ & 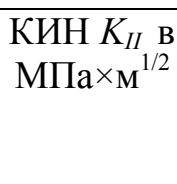 & $\begin{array}{c}\text { Разрушающая } \\
\text { нагрузка } Q_{t, i}, \\
\text { кН }\end{array}$ & $\begin{array}{c}\text { Несущая } \\
\text { способность } \\
\text { опорного } \\
\text { узлаQ } \mathrm{Q}_{\mathrm{d}} \mathrm{\kappa H}\end{array}$ \\
\hline \multirow{4}{*}{0,1} & 3 & 0,631 & 0,468 & 43,63 & 14,58 \\
\hline & 5 & 0,553 & 0,463 & 49,11 & 16,46 \\
\hline & 10 & 0,481 & 0,581 & 54,74 & 18,49 \\
\hline & 0 & - & - & 35,22 & 10,62 \\
\hline \multirow{4}{*}{0,2} & 3 & 0,855 & 0,606 & 31,33 & 10,54 \\
\hline & 5 & 0,794 & 0,604 & 33,39 & 11,26 \\
\hline & 10 & 0,710 & 0,603 & 36,71 & 12,43 \\
\hline & 0 & - & - & 27,46 & 9,19 \\
\hline \multirow[t]{4}{*}{0,3} & 3 & 1,049 & 0,729 & 24,89 & 8,42 \\
\hline & 5 & 1,002 & 0,722 & 25,94 & 8,79 \\
\hline & 10 & 0,923 & 0,699 & 28,09 & 9,52 \\
\hline & 0 & - & - & 23,11 & 7,78 \\
\hline \multirow[t]{4}{*}{0,4} & 3 & 1,257 & 0,871 & 20,14 & 6,86 \\
\hline & 5 & 1,200 & 0,834 & 21,26 & 7,23 \\
\hline & 10 & 1,113 & 0,809 & 22,86 & 7,78 \\
\hline & 0 & - & - & 17,95 & 6,14 \\
\hline \multirow[t]{4}{*}{0,5} & 3 & 1,457 & 0,953 & 17,27 & 5,89 \\
\hline & 5 & 1,408 & 0,946 & 17,81 & 6,08 \\
\hline & 10 & 1,359 & 0,929 & 18,45 & 6,30 \\
\hline & 0 & - & - & 16,16 & 5,50 \\
\hline
\end{tabular}


Таблица 2 - Результаты расчета опорных узлов балок с подрезкой поперечным сечением $b \times h=140 \times 500$ мм, усиленных арматурными стержнями, от действия усилия $Q=70$ кН

\begin{tabular}{|c|c|c|c|c|c|c|}
\hline $\begin{array}{c}\text { Отношение } \\
\mathrm{a} / \mathrm{h}\end{array}$ & $\begin{array}{c}\text { Диаметр двух } \\
\text { арматурных } \\
\text { стержней d, } \\
\text { мм }\end{array}$ & 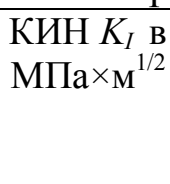 & 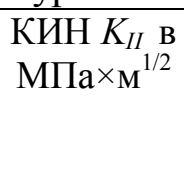 & $\begin{array}{c}\text { Напряжение в } \\
\text { арматурном } \\
\text { стержне, МПа }\end{array}$ & $\begin{array}{c}\text { Разрушающая } \\
\text { нагрузка } Q_{t, i} \\
\text { кН }\end{array}$ & $\begin{array}{c}\text { Несущая } \\
\text { способность } \\
\text { опорного } \\
\text { узла } Q_{d} \text { кН }\end{array}$ \\
\hline \multirow[t]{3}{*}{0,1} & 16 & 0,073 & 0,308 & 155 & 284,82 & 101 \\
\hline & 18 & 0,072 & 0,294 & 145 & 296,32 & 104,5 \\
\hline & 20 & 0,070 & 0,298 & 117 & 299,41 & 106 \\
\hline \multirow{3}{*}{0,2} & 16 & 0,086 & 0,380 & 190 & 220,28 & 79,4 \\
\hline & 18 & 0,084 & 0,370 & 165 & 228,16 & 82,08 \\
\hline & 20 & 0,080 & 0,361 & 144 & 239,61 & 86,19 \\
\hline \multirow{3}{*}{0,3} & 16 & 0,109 & 0,424 & 223 & 175,02 & 63,01 \\
\hline & 18 & 0,102 & 0,413 & 198 & 186,02 & 67,03 \\
\hline & 20 & 0,097 & 0,404 & 175 & 195,14 & 70,35 \\
\hline \multirow{3}{*}{0,4} & 16 & 0,135 & 0,463 & 259 & 143,39 & 51,49 \\
\hline & 18 & 0,126 & 0,450 & 230 & 152,92 & 54,96 \\
\hline & 20 & 0,119 & 0,440 & 205 & 161,16 & 57,97 \\
\hline \multirow{3}{*}{0,5} & 16 & 0,162 & 0,504 & 267 & 120,06 & 43,08 \\
\hline & 18 & 0,153 & 0,489 & 266 & 127,28 & 45,66 \\
\hline & 20 & 0,142 & 0,478 & 241 & 135,63 & 48,75 \\
\hline
\end{tabular}

Анализируя данные табл.1 и табл.2., можно отметить, что с увеличением отношения $a / h$ значения КИН $K_{I}$ и $K_{\text {II }}$ возрастают, т. е. несущая способность будет уменьшаться. В узлах с арматурными стержнями изменение величин КИН не столь значительно, так как большую часть растягивающих поперек волокон древесины и скалывающих вдоль волокон напряжений воспринимают арматурные стержни. При увеличении отношения $a / h$, увеличиваются максимальные значения растягивающих напряжений в арматурных стержнях. Увеличение диаметра арматурных стержней в рассмотренном диапазоне несущественно сказывается на уменьшении значений КИН.

Величины разрушающей нагрузки $Q_{t, i}$ и несущей способности $Q_{d, i}$ узлов для разных длин трещины определялись по формуле 2 с соответствующей подстановкой значений вязкости разрушения древесины при кратковременном и длительном действии нагрузки. Значения вязкости разрушения древесины для плотности $\rho=500$ кг $/ \mathrm{m}^{3}$, согласно данным [10], составили $K_{I C}=0,446 \mathrm{MПа} \times \mathrm{m}^{1 / 2}, K_{I I C}=1,075 \mathrm{MПа} \times \cdot \mathrm{M}^{1 / 2}$, а расчетные $K_{d, I C}=0,14 \mathrm{MПа}$ $\times \mathrm{M}^{1 / 2}$ и $K_{d, I I C}=0,71 \mathrm{MПа} \times \mathrm{M}^{1 / 2}$.

В результате аппроксимации значений $Q_{t, i}$ и $Q_{d, i}$ (табл. 1) были получены следующие выражения:

$$
\begin{array}{cc}
\text { для } a / h=0,1 & Q_{t, i}=35,22+4,584 l_{i}-0,2306 l_{i}^{2}, \\
& Q_{d, i}=10,62+1,55 l_{i}-0,076 l_{i}^{2}, \\
\text { для } a / h=0,2 \quad & Q_{t, i}=27,455+1,448 l_{i}-0,052 l_{i}^{2}, \\
& Q_{d, i}=9,19+0,504 l_{i}-0,018 l_{i}^{2}, \\
\text { для } a / h=0,3 \quad Q_{t, i}=23,11+0,63 l_{i}-0,014 l_{i}^{2}, \\
& Q_{d, i}=7,78+0,23 l_{i}-0,006 l_{i}^{2}, \\
\text { для } a / h=0,4 & Q_{t, i}=17,94+0,83 l_{i}-0,034 l_{i}^{2}, \\
& Q_{d, i}=6,14+0,27 l_{i}-0,011 l_{i}^{2}, \\
\text { для } a / h=0,5 & Q_{t, i}=16,16+0,43 l_{i}-0,02 l_{i}^{2}, \\
& Q_{d, i}=5,49+0,15 l_{i}-0,0731 l_{i}^{2}, \\
& -103-
\end{array}
$$


Разрушающая нагрузка $Q_{t}$ и несущая способность $Q_{d}$ узла определялись по аппроксимированным зависимостям $Q_{t, i}$ и $Q_{d, i}(3-7)$ при длине трещины $l=0$.

Анализируя значения несущей способности $Q_{d, i}$ для узлов без арматурных стержней, можно отметить, что с увеличением соотношения $a / h$ несущая способность уменьшается (табл. 1). Так, при $a / h=0,1 Q_{d}=10,62 \kappa \mathrm{H}$, а при $a / h=0,5 Q_{d}=5,5 \mathrm{\kappa H}$. Полученные значения несущей способности $Q_{d}$ (табл. 1) свидетельствуют о том, что несущая способность опорного узла значительно меньше несущей способности балки в пролетном сечении.

Таким образом, устройство подрезок в опорных сечениях балок приводит к значительному снижению их несущей способности. Установка вклеенных арматурных стержней способствует повышению сопротивления сечений сдвигу вдоль и растяжению поперек волокон древесины, расположенных в зоне подрезки балки, в среднем, в 10 раз (табл. 2).

Результаты экспериментальных исследований. В результате испытаний узлов без арматурных стержней было установлено, что разрушение их имело хрупкий характер и происходило в три стадии. На первой стадии в древесине, расположенной в зоне подрезки, при нагрузке $Q_{t 1}$ происходило образование продольной трещины (рис. 4). Вторая стадия разрушения узлов характеризовалась развитием трещины по длине при увеличении нагрузки. Третья стадия разрушения узлов характеризовалась быстрым развитием трещины и падением нагрузки.
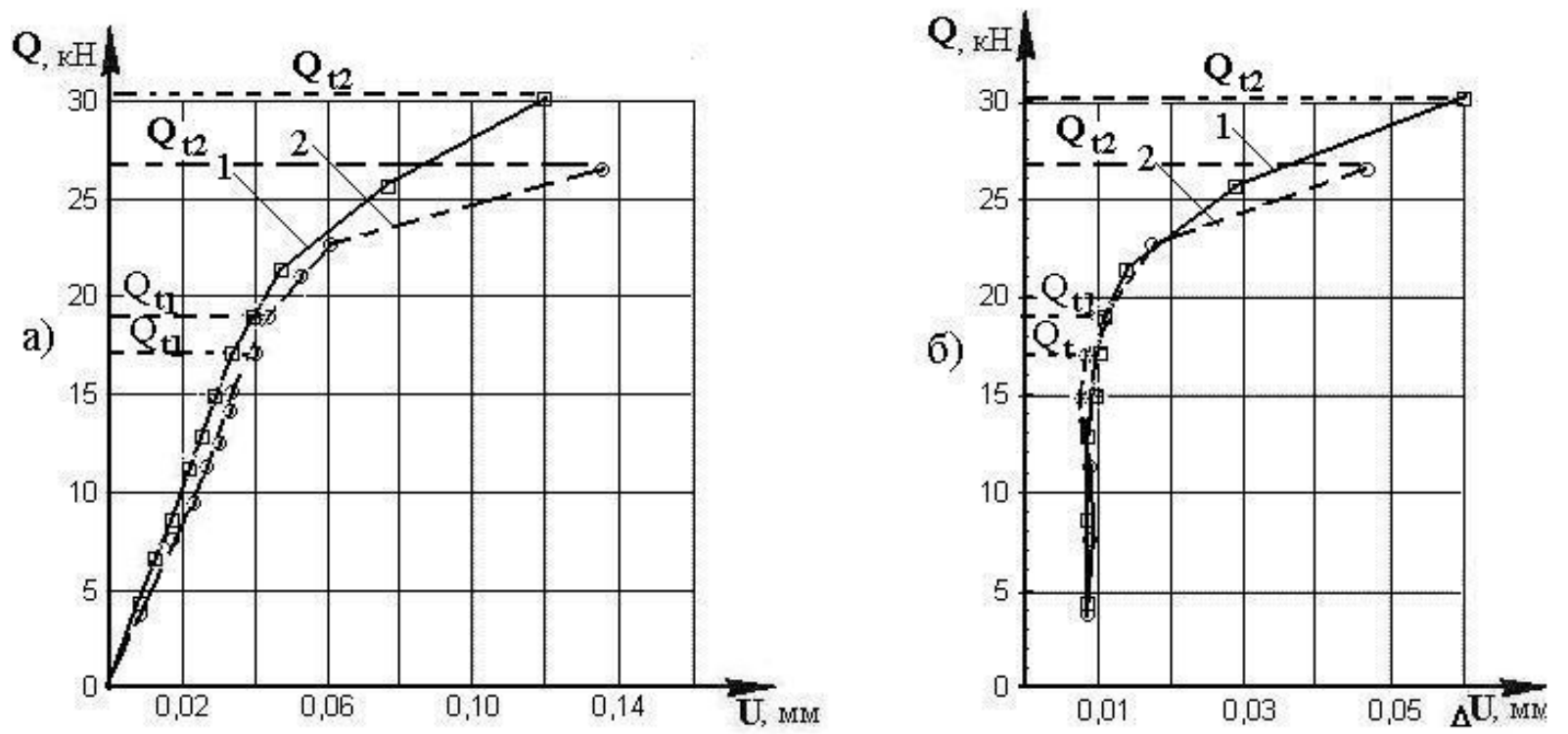

Рис. 4. Диаграммы полных деформаций древесины поперек волокон (а) и их разности (б) в зоне подрезки при испытании узлов поперечным сечением $b \times h=140 \times 500$ мм 1 - для образца Y-I-1-1 с $a / h=0,4 ; 2$ - для образца Y-II-1-1 с $a / h=0,5$

Разрушение узлов с арматурными стержнями происходило также в три стадии. На первой стадии разрушения, при нагрузке на 35 - 40\% выше, чем в узлах без стержней, происходило образование продольной трещины, которая с увеличением нагрузки продолжала развиваться и при достижении арматурных стержней наблюдалась ее остановка. При дальнейшем увеличении нагрузки происходило только раскрытие берегов трещины (вторая стадия). Полное разрушение узлов происходило в результате сдвига (скалывания, динамического развития трещины по длине образца за арматурными стержнями) древесины вдоль волокон. Так, для узла У-I-1-1 образование трещины произошло при величине опорной реакции $Q_{t 1}=18,6 \mathrm{\kappa H}$, а при нагрузке $Q_{t}=25,71$ кН длина трещины $l=24$ мм. Полное разрушение узла произошло при нагрузке $Q_{t 2}=30$ кН. Для узла У-I-2-1, усиленного двумя вертикальными арматурными стержнями диаметром $16 \mathrm{mм}$, при нагрузке $Q_{t 1}=25 \mathrm{\kappa H}$ происходило образование трещины, которая с увеличением нагрузки продолжала развиваться, а при достижении арматурных стержней происходила ее остановка, и 
наблюдалось только раскрытие берегов. При нагрузке $Q_{t 2}=150 \mathrm{\kappa H}$ произошло полное разрушение образца в результате скалывания древесины. Величина этой нагрузки была принята за разрушающее усилие. В процессе испытаний узлов выдергивания арматурных стержней из древесины, а также их разрыва не наблюдалось. Значения разрушающих нагрузок $Q_{t 1}$ и $Q_{t 2}$ и несущей способности $Q_{d 1, c p}$ испытанных узлов приведены в табл. 3.

Таблица 3 - Результаты испытаний опорных узлов балок с подрезками

\begin{tabular}{|c|c|c|c|c|c|c|c|}
\hline $\begin{array}{c}\text { Марка } \\
\text { образца }\end{array}$ & $\begin{array}{c}\text { Разрушаю } \\
\text { щая } \\
\text { нагрузка } \\
Q_{t l}, \text { кH } \\
\end{array}$ & $\begin{array}{c}\text { Среднее } \\
\text { значение } \\
Q_{t 1, c p}\end{array}$ & $\begin{array}{c}\text { Несущая } \\
\text { способность } \\
\text { по [12] } \\
Q_{d 1, c p}, \mathrm{\kappa H} \\
\end{array}$ & $\begin{array}{c}\text { Марка } \\
\text { образца }\end{array}$ & $\begin{array}{c}\text { Разрушаю } \\
\text { щая } \\
\text { нагрузка } \\
Q_{t 2}, \kappa \mathrm{H} \\
\end{array}$ & $\begin{array}{l}\text { Среднее } \\
\text { значение } \\
Q t_{2, c p}, \text { кН }\end{array}$ & $\begin{array}{c}\text { Несущая } \\
\text { способнос } \\
\text { ть по [12] } \\
Q_{d 1, c p}, \mathrm{\kappa H} \\
\end{array}$ \\
\hline Y-I-1-1 & 18,6 & \multirow{3}{*}{18,37} & \multirow{3}{*}{6,42} & Y-I-2-1 & 150.0 & \multirow{3}{*}{150,5} & \multirow{3}{*}{53,37} \\
\hline Y-I-1-2 & 17,5 & & & $\mathrm{y}-\mathrm{I}-2-2$ & 155,9 & & \\
\hline Y-I-1-3 & 19,0 & & & Y-I-2-3 & 145,6 & & \\
\hline Y-II-1-1 & 17,5 & \multirow{3}{*}{17,0} & \multirow{3}{*}{5,94} & Y-II-2-1 & 130,7 & \multirow{3}{*}{128,97} & \multirow{3}{*}{45,73} \\
\hline Y-II-1-2 & 17,0 & & & Y-II-2-2 & 126,4 & & \\
\hline Y-II-1-3 & 16,5 & & & Y-II-2-3 & 129,8 & & \\
\hline Y-III-1-1 & 33,6 & \multirow{3}{*}{31,0} & \multirow{3}{*}{10,83} & Y-III-2-1 & 260,0 & \multirow{3}{*}{276,06} & \multirow{3}{*}{92,89} \\
\hline Y-III-1-2 & 30,4 & & & Y-III-2-2 & 289,5 & & \\
\hline Y-III-1-3 & 28,0 & & & Y-III-2-3 & 278,7 & & \\
\hline
\end{tabular}

Сопоставляя значения разрушающих нагрузок $Q_{t 1, c p}$ и $Q_{t 2}$, а также несущей способности $Q_{d 1, c p}$, полученных в результате испытаний узлов поперечным сечением $b \times h=140 \times 500$ мм (табл. 3) со значениями разрушающей нагрузки $Q_{t, i}$ и несущей способности $Q_{d}$ для аналогичных узлов (табл. 1 и 2), полученных по МКЭ, можно отметить их хорошую сходимость. Так, для улов без арматурных стержней, при $a / h=0,5$ разрушающая нагрузка $Q_{t 1, c p}=17,0 \kappa \mathrm{H}$, а $Q_{t, i}=16,16 \kappa \mathrm{H}$, которые отличаются между собой на $5 \%$. Для тех же узлов, но с арматурными стержнями диаметром 16 мм $Q_{21, c p}=128,97$ кН (табл. 3), а $Q_{t, i}=120,06$ кН (табл.2), где разница в значениях составляет 6,9\%.

С целью сопоставления результатов испытаний образцов сечением $b \times h=160 \times 910$ мм с данными табл. 1 и 2 для узлов поперечным сечением $b \times h=140 \times 500$ мм определим величины касательных напряжений по нейтральной оси от действия разрушающих нагрузок исходя из зависимости

$$
\tau=\frac{1,5 Q}{b h},
$$

где $Q$ - величина поперечной силы в сечении; $b$ и $h$ - ширина и высота поперечного сечения.

Тогда для узлов поперечным сечением $b \times h=140 \times 500$ мм без арматурных стержней при $a / h=0,5$ при $Q_{t, i}=16,16$ кН (табл. 1) касательные напряжения $\tau=0,35$ МПа, а для узлов с $b \times h=160 \times 9100$ мм при $Q_{t 1, c p}=31,0$ кН (табл.3), $\tau=0,32$ МПа. Что же касается узлов с арматурными стержнями диаметром 20 мм, то для сечения $b \times h=140 \times 500$ мм при $Q_{t, i}=$ 135,63 кН (табл. 2) касательные напряжения $\tau=2,91$ МПа, а при $b \times h=160 x 9100$ мм и $Q_{t l, c p}$ $=276,06 \mathrm{\kappa H} \mathrm{(табл.3),} \tau=2,84$ МПа. Таким образом, результаты экспериментальных исследований согласуются с данными, полученными численным методом.

С целью оценки влияния концентрации напряжений в зоне подрезки на несущую способность опорных узлов балок был введен в качестве сомножителя к расчетному значению прочности древесины на скалывание вдоль волокон коэффициент $\mathrm{k}$, определяемый по формуле (9).

$$
k=\frac{\tau}{f_{v, d}}
$$


где $\tau$ - касательные напряжения, определяемые по формуле (8) при значениях $\mathrm{Q}=Q_{d, I}$

(табл. 1 или 2); $f_{v, d}$ - расчетное значение прочности древесины скалыванию вдоль волокон, определяемое в соответствии с [1].

В результате аппроксимации значений $k$, определенных по формуле (9), были получены следующие выражения:

$$
\begin{aligned}
& k=0,1787-0,2725 a / h+0,1378(a / h)^{2} \text { - для узлов без арматурных стержней; } \quad \text { (10) } \\
& k=1,8048-3,9654 a / h+3,1857(a / h)^{2}-\text { для узлов со стержнями диаметром } 16 \text { мм; (11) } \\
& k=1,8412-3,8529 a / h+2,9714(a / h)^{2} \text {-для узлов со стержнями диаметром } 18 \text { мм; (12) } \\
& k=1,842-3,5433 a / h+2,5071(a / h)^{2}-\text { для узлов со стержнями диаметром } 20 \text { мм. (13) }
\end{aligned}
$$
выводы:

Выводы. На основании выполненных исследований можно сделать следующие

- наличие подрезки в опорных узлах деревянных клееных балок со стороны растянутой кромки существенно снижает их несущую способность;

- установка вклеенных поперек волокон древесины двух арматурных стержней на расстоянии не менее трех диаметров от вертикальной грани подрезки способствует увеличению несущей способности узла в 8 - 10 раз, по сравнению с узлами без арматурных стержней;

- несущая способность опорных узлов балок с подрезками на опоре от действия скалывающих вдоль волокон древесины должна определяться из условия

$$
\frac{1,5 Q}{b \cdot h} \leq k \cdot f_{v, d}
$$

где $Q$ - величина опорной реакции; $b$ и $h$ - ширина и высота поперечного сечения балки; $k$ - коэффициент, определяемый по формулам $(10-13) ; f_{v, d}$ - расчетное значение прочности клееной древесины скалыванию вдоль волокон, определяемое по [1] в зависимости от класса прочности.

\section{Литература}

1. Еврокод 5. Проектирование деревянных конструкций. Часть 1-1. Общие правила и правила для зданий : ТКП ЕN 1995-1-1-2009. - Минск : Минстройархитектуры, 2010. - 110 с.

2. Деревянные конструкции. Нормы проектирования : ТКП 45-5.05-146 -2009. - Минск : Минстройархитектуры, 2009. - 72 с.

3. Иванов В.Ф. Деревянные конструкции. - Л.- М.: Госстройиздат, 1956 - 316 с.

4. Карлсен Г.Г., Большаков В.В., Каган М.Е. и др. Конструкции из дерева и пластмасс. М.: Стройиздат, 1975. -688 с.

5. Орлович Р.Б., Найчук А.Я. О применении критериев длительной прочности в расчета деревянных конструкций // Изв. вузов. Строительство и архитектура. - 1989. - №5 - С. 1519.

6. Фрейдин А.С., Отарбаев Ч.Т, Лемешова Т.Я. Развитие трещин в клееной древесине // Изв. Вузов. Лесной журнал. - 1986. - №3. - С. 59-63.

7. Фрейдин А.С., Вуба К.Т. Прогнозирование свойств клеевых соединений древесины. - М.: Лесн. Промышленность, 1980. - 224 с.

8. Найчук А.Я. Оценка прочности узлов деревянных клееных трехшарнирных арок методами механики разрушения// Промышленное и гражданское строительство. М., 2006. № 6. - С.34-35.

9. Найчук А.Я. Вязкость разрушения древесины сосны $\mathrm{K}_{\mathrm{IC}}$ и $\mathrm{K}_{\mathrm{IIC}}$ при совместном действии нормального отрыва и поперечного сдвига // Строительная механика и расчет сооружений. - 2006. - №4. - С.12 - 15 .

10. Найчук А.Я., Захаркевич И.Ф. Некоторые вопросы нормирования вязкости разрушения древесины // Вестник БрГТУ. Строительство и архитектура. - 2005. - №2(32). C.57-59. 
11. Орлович Р.Б., Найчук А.Я. О принципе Сен-Венана при загружении элементов из древесных материалов // Изв. вузов. Строительство и архитектура. - 1981.-№9 - С. 14-17.

12. Рекомендации по испытанию деревянных конструкций / ЦНИИСК. - М.: Стройиздат, 1976. -28 с.

\title{
References
}

[1] Yevrokod 5. Proyektirovaniye derevyannykh konstruktsiy. Chast' 1-1. Obshchiye pravila i pravila dlya zdaniy : TKP EN 1995-1-1-2009. - Minsk : Minstroyarkhitektury, 2010. - $110 \mathrm{~s}$.

[2] Derevyannyye konstruktsii. Normy proyektirovaniya : TKP 45-5.05-146 -2009. - Minsk : Minstroyarkhitektury, 2009.

[3] Ivanov V.F. Derevyannyye konstruktsii. - L.- M.: Gosstroyizdat, 1956 - 316 s.

[4] Karlsen G.G., Bol'shakov V.V., Kagan M.Ye. i dr. Konstruktsii iz dereva i plastmass. - M.: Stroyizdat, 1975.

[5] Orlovich R.B., Naichuk A.YA. O primenenii kriteriyev dlitel'noy prochnosti v rascheta derevyannykh konstruktsiy // Izv. vuzov. Stroitel'stvo i arkhitektura. - 1989. - №5 - S. 15-19.

[6] Freydin A.S., Otarbayev CH.T, Lemeshova T.YA. Razvitiye treshchin v kleyenoy drevesine // Izv. Vuzov. Lesnoy zhurnal. - 1986.

[7] Freydin A.S., Vuba K.T. Prognozirovaniye svoystv kleyevykh soyedineniy drevesiny. - M.: Lesn. Promyshlennost', 1980.

[8] Naichuk A.YA. Otsenka prochnosti uzlov derevyannykh kleyenykh trekhsharnirnykh arok metodami mekhaniki razrusheniya // Promyshlennoye i grazhdanskoye stroitel'stvo. M., 2006.

[9] Naychuk A.YA. Vyazkost' razrusheniya drevesiny sosny KIC i KIIC pri sovmestnom deystvii normal'nogo otryva i poperechnogo sdviga // Stroitel'naya mekhanika i raschet sooruzheniy. 2006.

[10] Naichuk A.YA., Zakharkevich I.F. Nekotoryye voprosy normirovaniya vyazkosti razrusheniya drevesiny // Vestnik BrGTU. Stroitel'stvo i arkhitektura. - 2005.

[11] Orlovich R.B., Naichuk A.YA. O printsipe Sen-Venana pri zagruzhenii elementov iz drevesnykh materialov // Izv. vuzov. Stroitel'stvo i arkhitektura. - 1981.

[12] Rekomendatsii po ispytaniyu derevyannykh konstruktsiy / TSNIISK. - M.: Stroyizdat, 1976.

\section{ОЦІНКА НЕСУЧОЇ ЗДАТНОСТІ ОПОРНИХ ВУЗЛІВ ДЕРЕВ'ЯНИХ КЛЕСНИХ БАЛОК 3 ПІДРІЗКАМИ}

\section{Найчук А.Я. д.т.н., проф. atnya@yandex.by, \\ УО «Брестський державний технічний університет»}

\begin{abstract}
Анотація. Одним з методів зменшення будівельної висоти покриття або перекриття 3 використанням клеєних дерев'яних балок, а також з'єднання по їх довжині є виконання підрізувань в опорних вузлах. Такий же метод використовують при проектуванні балкових перекриттів, де спирання другорядних балок на головні здійснюється в заздалегідь вибрані гнізда як в головних так і другорядних балках. Що ж стосується розрахунку таких вузлів, то в нормативних документах наведена лише методика розрахунку для випадку, коду в опорних вузлах підрізування виконується зі скосом, або ж встановлюються жорсткі обмеження щодо глибини підрізування балки без скосу з боку розтягнутої зони по відношенню до іiі висоті. Крім того в ряді нормативних документів рекомендується в зоні підрізування встановлювати вклеєні або угвинчені стрижні, але будь-яких даних по їх розрахунку не наводиться. Тому метою даних досліджень було розробити модель, що дозволяє оцінити несучу здатність опорних вузлів дерев'яних клеєних балок 3 підрізуваннями різної глибини по висоті поперечного перерізу, а також елементами посилення у вигляді вклеєними перпендикулярно волокнам сталевих стрижнів. Для досягнення поставленої мети були виконані експериментально-теоретичні дослідження фрагментів опорних вузлів балок 3
\end{abstract}


використанням методів механіки руйнування. Теоретичні дослідження виконувалися 3 використанням програми в якій реалізовано метод скінченних елементів та реалізовано процедуру визначення коефіцієнтів інтенсивності напружень. В результаті чисельних досліджень, за запропонованою методикою, що базується на використанні критерію руйнування, визначені закономірності зміни несучої здатності в залежності від відношення глибини врізки і діаметра вклеєних арматурних стрижнів. В результаті випробувань натурних фрагментів опорних вузлів балок 3 підрізуваннями підтверджена достовірність прийнятої методики чисельних досліджень і розробленої моделі визначення несучої здатності вузлів. На основі отриманих результатів досліджень встановлено, що наявність підрізування в опорних вузлах дерев'яних клеєних балок з боку розтягнутої кромки істотно знижує їх несучу здатність, а установка вклеєних поперек волокон деревини двох арматурних сталевих стрижнів діаметром від 16 мм до 20 мм на відстані не менше трьох діаметрів від вертикальної грані підрізування підвищує несучу здатність вузла в 8 - 10 разів, в порівнянні з вузлами без арматурних стрижнів.

Ключові слова: вклеєний стрижень, дерев'яна балка, коефіцієнт інтенсивності напружень, руйнівне навантаження, опір, несуча здатність.

\title{
THE LOAD BEARING CAPACITY OF GLULAM BEAMS WITH NOTCHES AT THE SUPPORT
}

\author{
Naichuk A.Ya., Dr.Sc. in Engineering. \\ atnya@yandex.by, ORCID 0000-0000-0000-0000 \\ Brest State Technical University
}

\begin{abstract}
One of the methods of reducing the construction height of the coating or overlap using glued wooden beams, as well as the connection along their length is to perform undercuts in the support nodes. The same method is used in the design of beam ceilings, where the support of secondary beams on the main ones is carried out in pre-selected sockets in both the main and secondary beams. As for the calculation of such nodes, the normative documents only provide a calculation method for the case when the support nodes are cut with a bevel, or strict restrictions are set regarding the depth of cutting a beam without a bevel on the side of the stretched zone in relation to its height. In addition, a number of regulatory documents recommend installing glued or screwed rods in the pruning area, but no data on their calculation is provided. Therefore, the aim of this research was to develop a model allowing to estimate the carrying capacity of supporting assemblies of wooden glued beams with various depths of cut according to the height of the crosssection, and reinforcements in the form of glued perpendicular to the fiber steel rods. To achieve this goal, experimental and theoretical studies of fragments of beam support units were performed using methods of fracture mechanics. Theoretical studies were performed using a program that implemented the finite element method and implemented a procedure for determining stress intensity coefficients. As a result of numerical studies, according to the proposed method based on the use of the failure criterion, the regularities of changes in the bearing capacity depending on the ratio of the depth of the inset and the diameter of the glued reinforcing rods are determined. As a result of tests of full-scale fragments of support nodes of beams with undercutting, the reliability of the accepted method of numerical research and the developed model for determining the bearing capacity of nodes was confirmed. Based on the obtained research results, it was found that the presence of undercutting in the support nodes of wooden glued beams on the side of the stretched edge significantly reduces their load - bearing capacity, and the installation of two reinforcing steel rods with a diameter of $16 \mathrm{~mm}$ to $20 \mathrm{~mm}$ glued across the wood fibers at a distance of at least three diameters from the vertical face of the undercut increases the load-bearing capacity of the node by 8 to 10 times, compared to nodes without reinforcing rods.
\end{abstract}

Keyword: tipped-in stud, timber beam, the stress intensity factor, breaking load, resistance load-bearing capacity. 


\title{
ЩОДО МОЖЛИВОСТІ ВИКОРИСТАННЯ ТЕРМОГРАФІЧНОГО СПОСОБУ КОНТРОЛЮ ДЛЯ ВИЯВЛЕННЯ ТРІЩИН У СТАЛЕВИХ КОНСТРУКЦІЯ
}

\author{
Попаденко А.О., магістр, \\ popadenko@donnaba.edu.ua, ORCID:0000-0002-5615-7117 \\ Колесніченко С.В., к.т.н., доцент \\ Донбаська національна академія будівництва і архітектури \\ svk.mk15@gmail.com, ORCID: 0000-0001-5087-8354
}

Анотація. У статті наведені результати дослідження можливості використання термографічного неруйнівного контролю для пошуку тріщин у сталевих конструкціях. Описано експеримент що доводить можливість застосування термографічного неруйнівного контролю для виявлення тріщини у сталевих конструкціях. У якості вимірювальних приладів для проведення експерименту використовувалися тепловізори із різною роздільною здатністю матриці ІЧ-зображення, інфрачервоний термогігрометр, люксметр. Автори роблять висновки про те, що спосіб термографічного контролю може бути використаний під час обстеження сталевих конструкцій для якісного оцінювання наявності тріщин.

Ключові слова: сталеві конструкції, тріщина, термографія, інфрачервона камера, неруйнівний контроль.

Вступ. Питання виконання вимог нормативних документів щодо експлуатації сталевих конструкцій $\epsilon$ основним для забезпечення нормального виробничого процесу та гарантування безпеки персоналу промислових підприємств, особливо через великий відсоток конструкцій, що експлуатуються за межами свого проектного ресурсу, що призводить до збільшення кількості випадків техногенних аварій [1].

Виникнення аварійних ситуацій спричинених металевими конструкціями пов'язано 3 багатьма факторами, але практично завжди обумовлено утворенням пошкоджень в елементах цих конструкцій. Самим небезпечним пошкодженням для сталевих конструкцій $\epsilon$ тріщини. Використання конструкцій із тріщиною заборонено нормами [2] у зв'язку із неможливістю прогнозування їх розвитку, що призводить до подальшого руйнування конструкції.

Під час проведення технічного обстеження сталевих будівельних конструкцій використовують наступні методи неруйнівного контролю: візуальний, ультразвуковий, рентгенівський, вимірювальний, електромагнітний, капілярний, тощо. Всі ці методи дозволяють вирішити задачу виявлення і визначення параметрів дефектів та пошкоджень, однак, як правило, вимагають досить трудомістких робіт, тривалих технологічних перерв у виробництві при проведенні контролю. Також, їх використання у виробничих умовах ускладнене у зв'язку із необхідністю ви-конання жорстких вимог до підготовки поверхні, що потребує часу та значних матеріальних витрат. Враховуючи обмеження: неможливість доступу до всієї поверхні конструкції, обмежена кількість працівників, неможливість стаціонарного електропостачання - більшість площі конструкції не може бути обстеженою, що призводить до відповідних допущень у висновках за результатами обстеження, та наявності великих ризиків можливості розвитку невиявлених дефектів та пошкоджень.

Неруйнівний термографічний контроль [3] може використовуватися під час виробництва деталей для автоматичного виявлення відхилення геометричних показників виробів та наявності поверхневих дефектів [4]. Для виявлення поверхневих дефектів сталевих конструкцій може використовуватися сканування поверхні конструкції що нагрівається за допомогою лазерного променя, відхилення форми теплової точки буде свідчити про наявність дефекту поверхні [5].

Аналіз останніх досліджень і публікацій. Розробка методик i апаратури термографічного контролю (ТК), орієнтованих на діагностику стану i дослідження 
теплофізичних характеристик різних матеріалів, здійснюється в провідних наукових лабораторіях США, Канади. Німеччині. Франції. Фінляндії, Росії, а в останні роки Індії та Китаю.

Перші дослідження по ТК були виконані ще в 70-ті роки минулого століття Н. А. Бекешко, В.П. Вавілов, Ю.А. Поповим, Д.А. Рапопортом, П. Н. Будадіним, Б.Н. Епіфанцевим. В останні роки проблемі ТК присвячено дослідження Е. В. Абрамова, А Н. Чепрасова, В. А. Захаренко, В.Г. Торгунакова.

Більша частина уваги у вищезазначених дослідженнях приділяється методам та приладам термографічного контролю, що націлені на виявлення пошкоджень під час їх виникнення. Зокрема, у своїй роботі В. В. Котельников [7], розглядає методи і пристрої ТК, грунтуючись на тому, що під час виникнення деформацій у сталевих конструкціях, під впливом механічних напруг, виділяється певна кількість енергії (тепла), котра фіксується за допомогою інфрачервоної камери такий метод теплового неруйнівного контролю називається пасивним і не дає змогу виявляти дефекти після їх утворення.

Постановка завдання. Основою неруйнівного теплового контролю $є$ реєстрація змін теплового поля, що виникає під час порушення термодинамічної рівноваги об'єкта із оточуючим середовищем, яке з'являється на поверхні, та характер якого дозволяє отримати необхідну інформацію. Метод теплового контролю базується на взаємодії теплового поля об'єкта із термодинамічними чутливими елементами (термопара, фотоприймальник, рідкокристалічний елемент, болометр), що перетворюють параметри поля (інтенсивність, температурний градієнт, контрастність, променистість) в електричний сигнал реєструючого пристрою.

В термографічному способі контролю у якості енергії використовується теплова енергія, що розповсюджується у об'єкті контроля. Температурне поле поверхні є джерелом інформації особливостей процесу теплопередачі, які, в свою чергу, залежать від наявності внутрішніх дефектів (пошкоджень).

Умовно розрізняють пасивний тепловий неруйнівний контроль (ПТНК), активний (АТНК) та комбіновані способи термографічного контролю [6]. Пасивний не потребує зовнішнього теплового впливу, активний, навпаки, передбачає нагрів об'єкта дослідження зовнішнім теплом. Комбіновані методи потребують додаткового використання інших методів неруйнівного контроля.

Пасивним методом контролюють виникнення дефектів та пошкоджень під час роботи та (або) експлуатації об'єкта. Це найбільш поширені методи, що використовуються під час енергетичного аудиту, контролю приладів, що працюють під напругою.

Активний метод використовують, коли під час експлуатації об'єкта не виділяється достатня кількість теплового випромінювання для виконання обстеження. В цьому випадку об'єкт додатково нагрівають зовнішнім джерелом тепла [8].

Найбільш поширеними приладами теплового контролю $\epsilon$ інфрачервоні камери (тепловізори). Прилади обладнані інфрачервоними датчиками (болометрами) та спеціальним цифровим дисплеєм, де відображається картина теплового поля. Як правило, всі тепловізори мають спеціальне програмне забезпечення для обробки отриманих термограм. Також існує розподілення на наглядові та вимірювальні тепловізори, але перші не мають широкого спеціального використання, тому що, як правило, контролюється значення температур поверхня об'єкта.

Теплопровідність - здатність речовини переносити теплову енергію, а також кількісна оцінка цієї здатності: фізична величина, що характеризує інтенсивність теплообміну в речовині, яка дорівнює відношенню густини теплового потоку до градієнта температури. Явище теплопровідності полягає в тому, що кінетична енергія атомів й молекул, яка визначає температуру тіла, передається атомам і молекулам у тих областях тіла, де температура нижча.

Найбільшу теплопровідність мають речовини, в яких тепло переноситься вільними електронами, що зумовлено їхньою малою масою. Саме тому 
теплопровідність металів зазвичай висока. В нагрітій області речовини є більше електронів із високою енергією, вони легко мігрують в холодніші області, й втрачають там енергію, розсіюючись на коливаннях кристалічної гратки.

У структурно однорідних тілах розповсюдження тепла шляхом теплопровідності (тепловий градієнт) відбувається рівномірно у всі сторони від найгарячішої точки (рис. 1), у випадку коли тіло має структурні неоднорідності або пошкодження (наприклад тріщину), виникає помітна “ступінчастість" теплового градієнта (рис. 2), що помітна на термограмах, отриманих під час проведення тепловізійного обстеження.

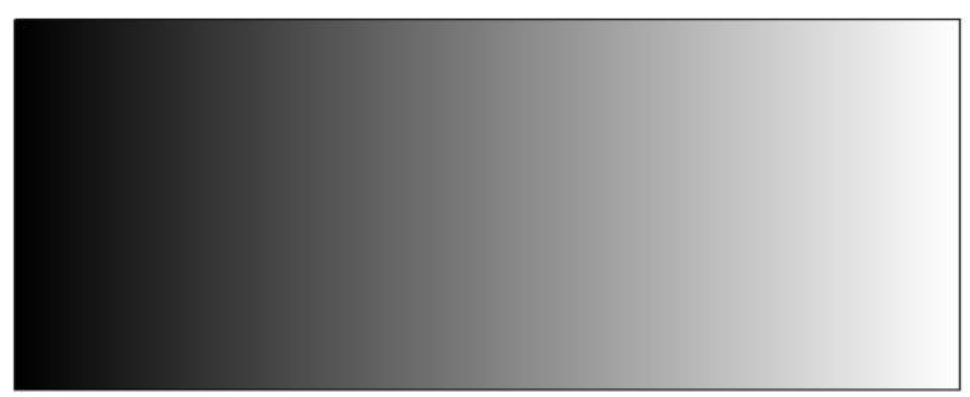

Рис. 1 Тепловий градієнт однорідної металевої пластини

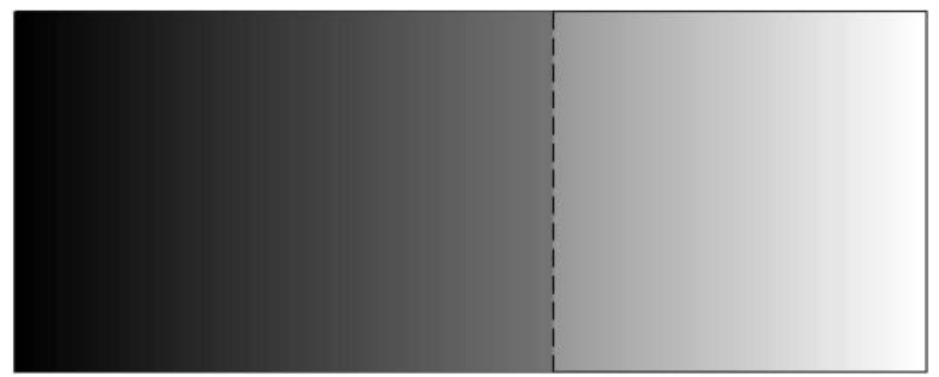

Рис. 2 Тепловий градієнт однорідної металевої пластини з тріщиноподібним дефектом

Також АТНК можна розподілити на контроль під час нагрівання, та контроль під час охолодження. АТНК під час нагрівання доцільно використовувати для виявлення ділянок неоднорідності в переважно однорідних тілах, АТНК під час охолодження дозволяє виявити чужорідні включення (наприклад ділянки корозійного ураження, коли замість металу присутній його оксид), виконувати контроль зварних з'єднань оскільки матеріал зварного шва відрізняється від матеріалу конструкції він охолоджується з іншою (відносно матеріалу конструкціі) швидкістю.

Завданням дослідження є експериментальне визначення можливості та ефективності використання АТНК для пошуку та ідентифікації візуально невизначених тріщин у сталевих конструкціях.

Основний матеріал. У якості вимірювальних приладів для проведення експерименту використовувалися тепловізори FLIR C2 із роздільною здатністю матриці IЧ-зображення (термічного зображення) 80x60 пікселів та FLIR E8 із роздільною здатністю матриці IЧзображення 320x240 пікселів, інфрачервоний термогігрометр, люксметр.

Задачі експериментальних досліджень включали:

1. Вивчення можливостей принципового застосування термографічного пособу контролю для обстеження сталевих конструкцій.

2. Пошук вирішення можливих проблем роботи із приладами.

3. Розробка методики виконання робіт при проведені обстеження способом термографічного контролю з урахуванням реального стану конструкцій.

Для проведення експерименту у якості об’єктів дослідження було використано зразки металевих конструкцій та їх частин на яких було імітовано тріщину що подолала $60-80 \%$ 
товщини металу, розриви металу та корозійне пошкодження, далі приведено опис зразків що досліджувалися.

Зразок № 1 - балка сталева двотаврова №16, імітація тріщини що переходить у розрив 3 розкриттям 0,8-1,8 мм, розрив заповнений фарбою та гіпсовою штукатуркою, ділянки уражені корозією (рис. 3).

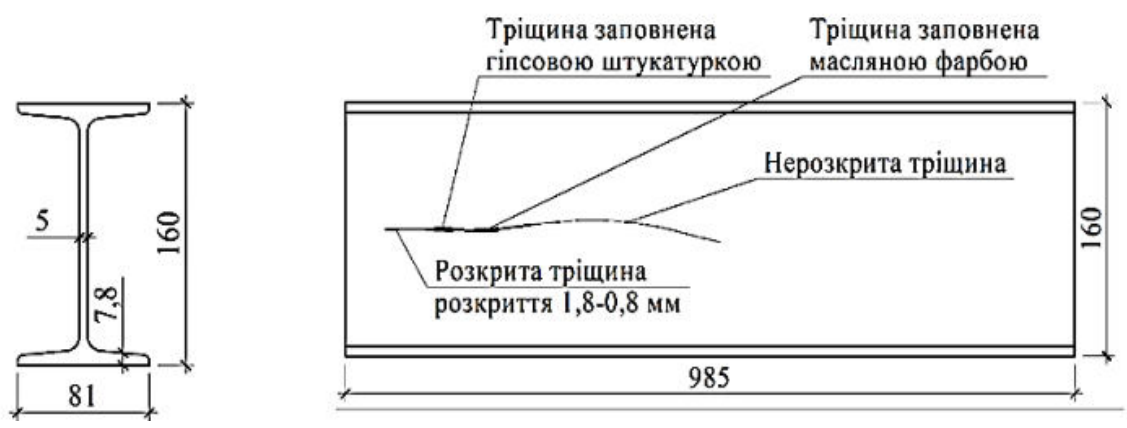

a)

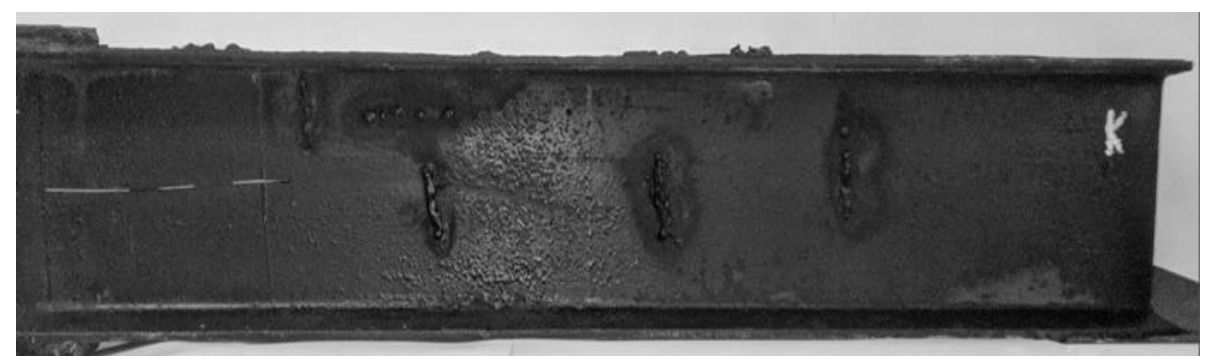

б)

Рис. 3 Зразок № 1 а) схематичне зображення, б) фотографія зразку

Зразок № 2 - Труба сталева, товщина 4 мм, діаметр 103 мм, імітація розриву 3 розкриттям 0,2-3,0 мм (рис. 4).

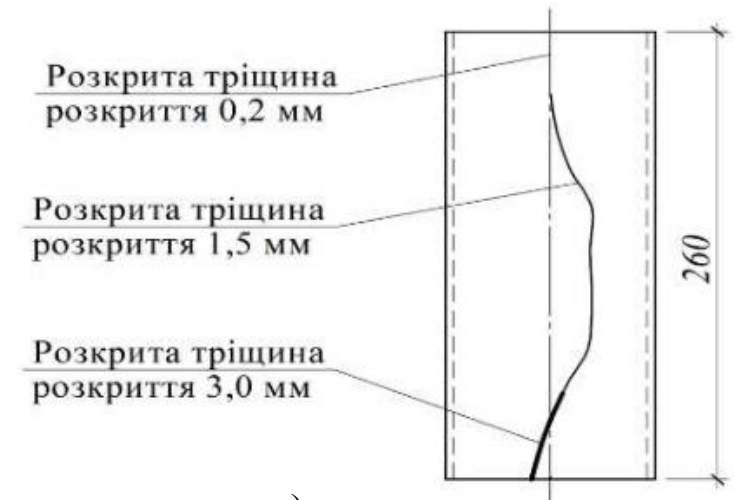

a)

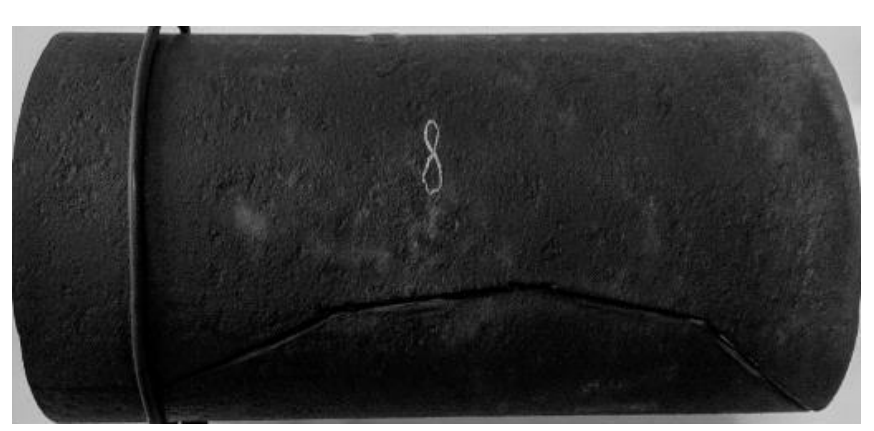

б)

Рис. 4 Зразок № 2 а) схематичне зображення, б) фотографія зразку

Зразок № 3 - Труба сталева, товщина 4 мм, діаметр 103 мм, імітація розриву 3 розкриттям 0,2-2,0 мм (рис. 5). 


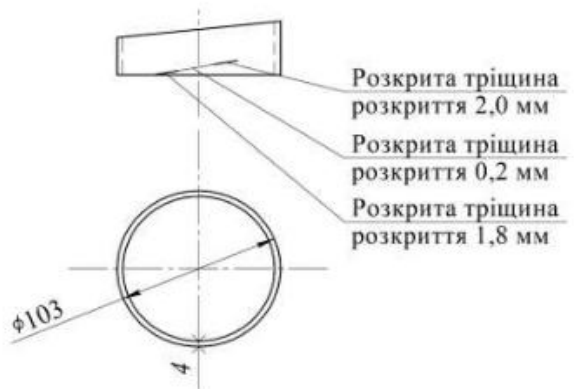

a)

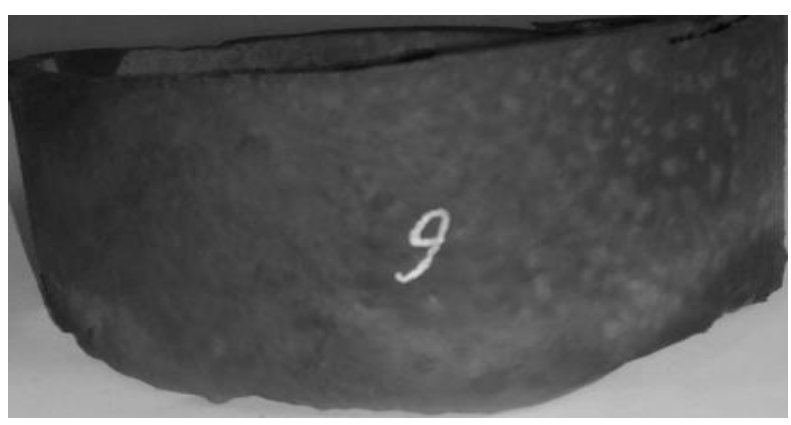

б)

Рис. 5 Зразок № 3 а) схематичне зображення, б) фотографія зразку

Зразок № 4 - Балка сталева коробчастого перетину 80x80 мм, товщина стінки 3 мм, імітація розриву з розкриттям 0,3-1,0 мм (рис. 6).

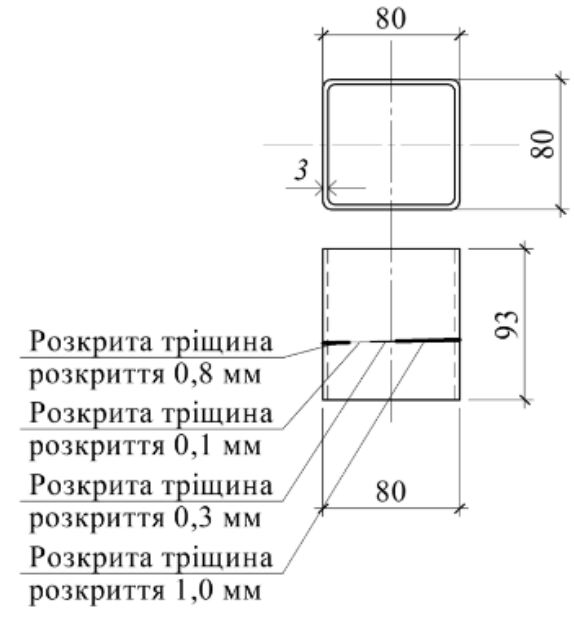

a)

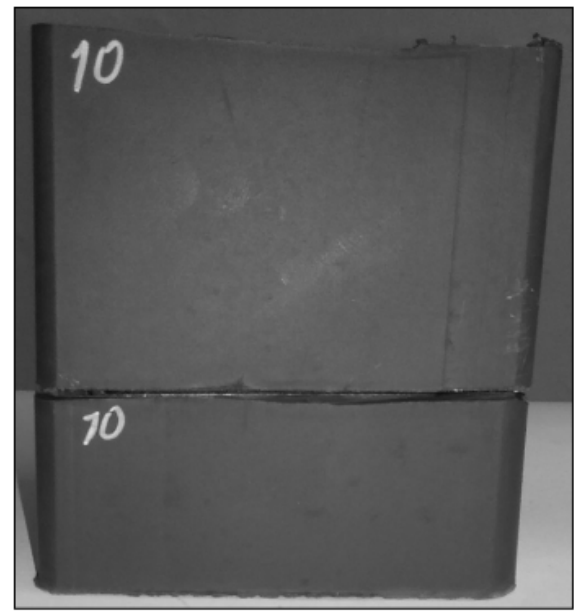

б)

Рис. 6 Зразок № 4 а) схематичне зображення, б) фотографія зразку

Зразок № 5 - Сталевий лист товщиною 5 мм, імітація тріщин що переходять у розриви 3 розкриттям до 1,5 мм (рис. 7).

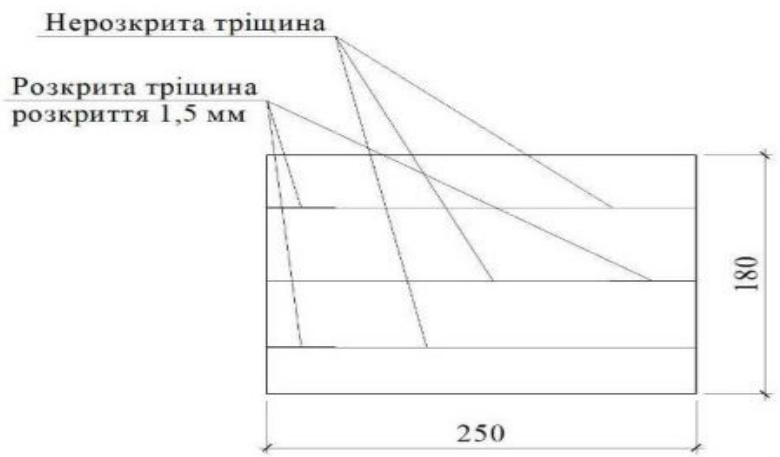

a)

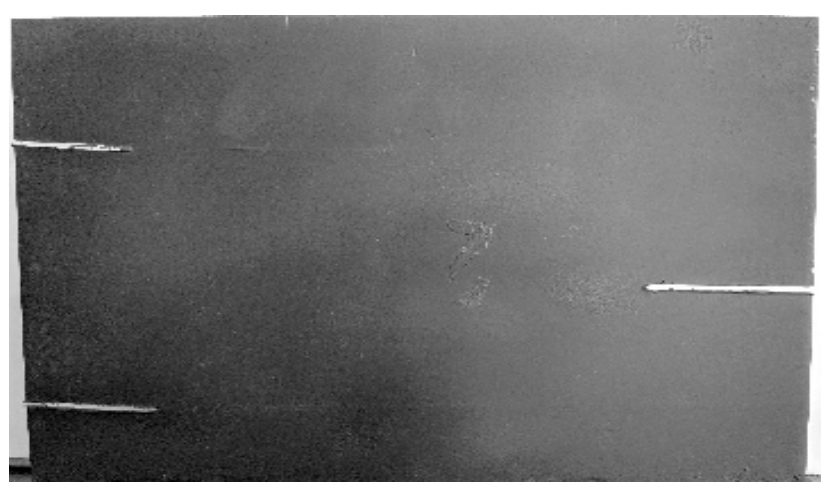

б)

Рис. 7 Зразок № 5 а) схематичне зображення, б) фотографія зразку

Методика проведення досліджень включала наступні основні операції: 
1. Огляд та попередня оцінка зразків металевих конструкцій, що мають дефекти та пошкодження, визначення яких візуальним методом ускладнене або неможливе.

2. Визначення кліматичних параметрів зони проведення дослідження (температура, відносна вологість, природня освітленість).

3. Нагрів зразків до температури $\approx 373^{0} \mathrm{~K}\left(\approx 100^{0} \mathrm{C}\right)$.

4. Сканування та запис термограм на інфрачервоні камери Flir C2 та Flir Е8 при природному охолодженні зразків до температури $\approx 323^{0} \mathrm{~K}\left(\approx 50^{0} \mathrm{C}\right)$.

5. Обробка даних з термограм за допомогою програмного комплексу Flir Tools.

6. Порівняння даних, отриманих за допомогою інфрачервоних камер Flir C2 та Flir E8.

7. Визначення місць пошкоджень на термограмах із формуванням зразків термограм.

Нагрів досліджуваного зразку виконувався різними шляхами: конвективний нагрів, нагрів випроміненням, контактний нагрів.

В результаті проведення експерименту було підтверджено що термографічний спосіб контролю може бути використаний під час обстеження сталевих конструкцій для якісного оцінювання наявності прихованих дефектів та пошкоджень. На Рис. 8 показано компіляцію цифрового та інфрачервоного зображення ділянки двотаврової сталевої балки товщиною 6мм, на інфрачервоному зображенні видно приховану тріщину, вона виглядає як різка зміна теплового поля.

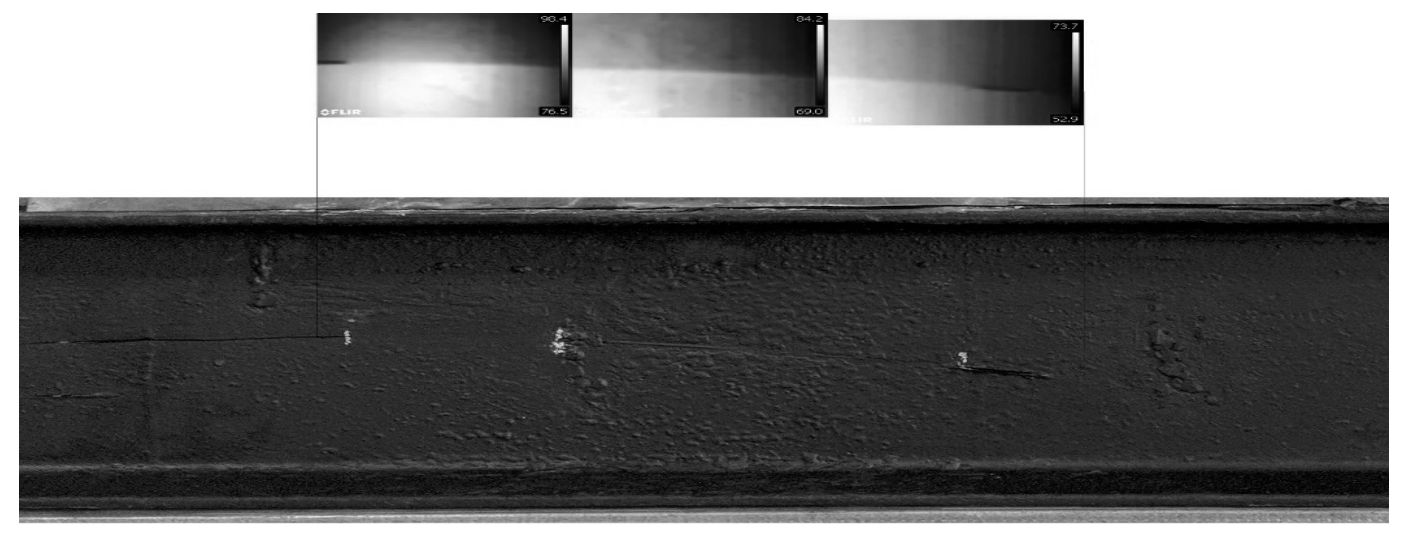

Рис. 8 Компіляція цифрового та інфрачервоного зображення досліджуваного зразку №1.

На Рис. 9 показано фотографічне (а) та інфрачервоне (б) зображення зразка № 5, так само приховані тріщини виглядають як різкі зміни теплового поля.

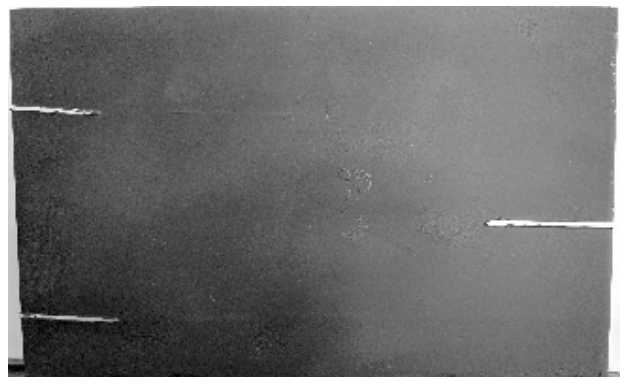

a)

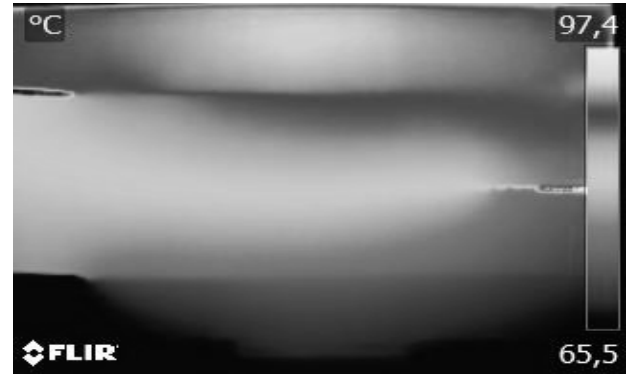

б)

Рис. 9 Зображення зразка № 5 (а фотографічне, (б інфрачервоне 
На Рис. 10 зображено інфрачервоні зображення зразків 2, 3 і 4 на них видно що ділянки металу що розділені розривами різко відрізняються за поверхневою температурою.

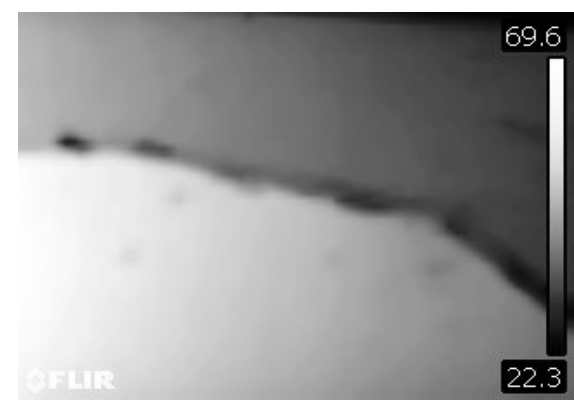

a)

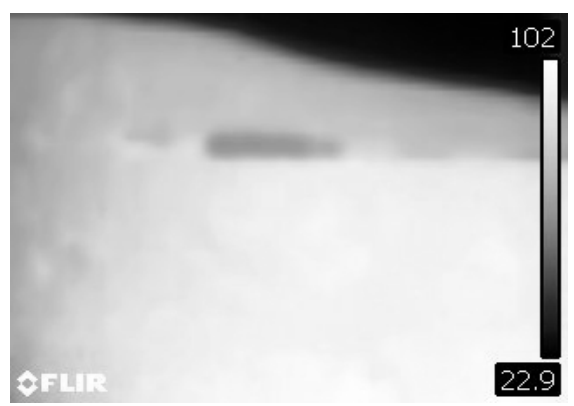

б)

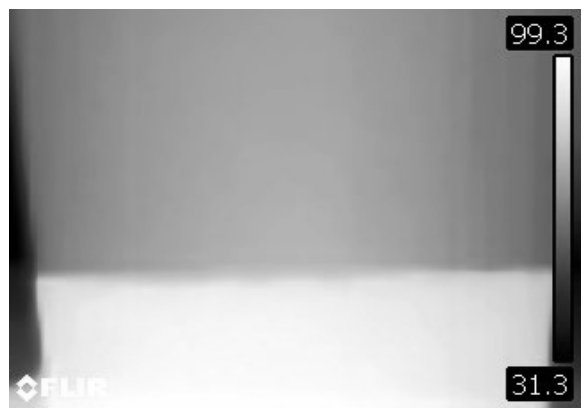

B)

Рис. 10. Інфрачервоні зображення зразків а) зразок № 2, б) зразок № 3, в) зразок № 4.

Таким чином для отримання достовірних даних при використанні методу активної термографії необхідно враховувати наступні параметри:

- температура повітря навколишнього середовища;

- вологість повітря;

- ступінь блиску об'єкта, при високому ступені блиску досліджуваного об'єкта необхідно нанесення спеціального покриття, що володіє високим коефіцієнтом випромінювання;

- кут нахилу оптичної осі вимірювального приладу до поверхні досліджуваного об'єкта;

- природна освітленість об'єкта дослідження;

- наявність в полі зору тепловізора високотемпературних об'єктів.

Висновки. Метод теплового контролю не потребує високоточного інфрачервоного обладнання. Під час проведення експерименту не було знайдено принципової різниці застосування тепловізорів із різними типами ІЧ матриць. При використанні більш точного тепловізора Flir E8 теплограма мала чіткіше визначення температури поверхні, порівняно із Flir C2. Ця особливість може стати у нагоді для кількісного визначення дефектів - на приклад, глибини та розмірів тріщини під шаром фарби, але принципово, для якісного знаходження дефектів та пошкоджень, використання більш точного обладнання не $\epsilon$ обов'язковою умовою.

Оптимальним методом нагріву виявився контактний нагрів оскільки він дозволяє точно локалізувати зону нагріву зразка.

Значною мірою на якість термограм впливає ступінь блиску поверхні досліджуваного об'єкта, високий ступінь блиску не дозволяє отримати достовірні дані, для зниження ступеню блиску поверхню досліджуваного об'єкту необхідне нанесення спеціального покриття з високим коефіцієнтом випромінення. 
Із вищезазначених даних випливає те, що використання теплового неруйнівного способу контролю значно збільшує імовірність знаходження місць розташування небезпечних прихованих дефектів та пошкоджень та підвищує якість результатів проведення обстеження технічного стану металевих конструкцій.

\section{Література}

1. Thoft-Christensen, P. (2001). Risk Analysis in Civil Engineering. Aalborg: Dept. of Building Technology and Structural Engineering. Structural Reliability Theory, No. 224, Vol. R0163. - p.24.

2. Eurocode 3: ENV 1993-1-1, Design of Steel Structures, Part 1.1: General rules and rules for the buildings. CEN, Brussels, 2005.

3. A. Killey, J. P. Sargent, "Analysis of thermal nondestructive testing”, 22(1):216, 2000.

4. Beate Oswald-Tranta, Paul O'Leary, "Fusion of geometric and thermographic data for automated defect detection", April 2012, Journal of Electronic Imaging 21(2):1108.

5. S. E. Burrows, S. Dixon, Simon Gideon Pickering, Teng Li, D. P. Almond, "Thermographic detection of surface breaking defects using a scanning laser source", November 2011, NDT \& E International 44(7):589-596.

6. Europian Standart EN 16714-1 Non-destructive testing - Thermographic testing - Part 1: General principles.

7. Котельников В. В. Дисертація на здобуття вченого ступеню кандидата технічних наук «Разработка методики теплового контроля и диагностики технического состояния металлоконструкций мостовых кранов». МГУ ім Н. С. Баумана. Москва, 2009. С. 35.

8. M. Belkacemi, C. Stolz, A. Mathieu, G. Lemaitre, J. Massich, O. Aubreton, "Nondestructive testing based on scanning-from-heating approach: Application to nonthrough defect detection and fiber orientation assessment", Journal of Electronic Imaging, 24(6):061112, 2015.

9. Патент України на корисну модель № 117575 від 26.06.2017.Спосіб безконтактної дефектоскопії металевих конструкцій. Колесніченко С.В., Шарабарін О.Г., Точонов І.В., Ковтун С.В., Мнацаканян К.Б., Путілін С.В., Попаденко А.О.

10. Патент України № 125968. Спосіб безконтактної дефектоскопії металевих конструкцій. Зареєстровано в Державному реєстрі патентів України на корисні моделі 25.05.2018. // Кравець В.А., Колесніченко С.В., Точонов I.В., Мнацаканян К.Б., Шарабарін О.Г., Гололобов Б.Д., Попаденко А.О.

\section{References}

[1] Thoft-Christensen, P. (2001). Risk Analysis in Civil Engineering. Aalborg: Dept. of Building Technology and Structural Engineering. Structural Reliability Theory, No. 2 224, Vol. R0163. p.24.

[2] Eurocode 3: ENV 1993-1-1, Design of Steel Structures, Part 1.1: General rules and rules for buildings. CEN, Brussels, 2005.

[3] A. Killey, J. P. Sargent, "Analysis of thermal nondestructive testing”, 22 (1): 216, 2000.

[4] Beate Oswald-Tranta, Paul O'Leary, "Fusion of geometric and thermographic data for automated defect detection," April 2012, Journal of Electronic Imaging 21 (2): 1108.

[5] SE Burrows, S. Dixon, Simon Gideon Pickering, Teng Li, DP Almond, "Thermographic detection of surface breaking defects using a laser scanning source", November 2011, NDT \& E International 44 (7): 589 -596.

[6] Europian Standart EN 16714-1 Non-destructive testing - Thermographic testing - Part 1: General principles. CEN, Brussels, 2016. 
[7] Kotelnikov V.V. Dissertation for the degree of Candidate of Technical Sciences "Development of the method of thermal control and diagnostics of the technical state of metal structures of bridge cranes". Bauman MSU. Moscow, 2009. P. 35.

[8] M. Belkacemi, C. Stolz, A. Mathieu, G. Lemaître, J. Massich, and O. Aubreton, "Nondestructive testing based on a scanning-from-heating approach: Application to nonthrough defect detection and fiber orientation assessment", Journal of Electronic Imaging, 24 (6): $061112,2015$.

[9] Kolesnichenko S.V., Sharabarin O.G., Tochonov I.V., Kovtun S.V., Mnatsakanyan K.B., Putilin S.V., Popadenko A.O. Patent of Ukraine No. 117575 from 06/26/2017. Method of contactless flaw detection of metal structures.

[10] Kravets V.A., Kolesnichenko S.V., Tochonov I.V., Mnatsakanyan K.B., Sharabarin O.G., Gololobov B.D., Popadenko A.O. Patent of Ukraine No. 125968 from 05/25/2018. Method for non-contact defectoscopy of metal structures.

\title{
ВОЗМОЖНОСТЬ ИСПОЛЬЗОВАНИЯ ТЕРМОГРАФИЧЕСКОГО СПОСОБА КОНТРОЛЯ ДЛЯ ВЫЯВЛЕНИЯ ТРЕЩИН В СТАЛЬНЫХ КОНСТРУКЦИЯХ
}

\author{
Попаденко А.А., магистр, \\ popadenko@donnaba.edu.ua, ORCID: 0000-0002-5615-7117 \\ Колесниченко С.В., к.т.н., доцент \\ Донбасская нащиональная академия строительства и архитектуры \\ svk.mk15@gmail.com, ORCID: 0000-0001-5087-8354
}

Аннотация. В статье приведены результаты исследования возможности использования термографического неразрушающего контроля для поиска трещин в стальных конструкциях. Основой неразрушающего теплового контроля является регистрация изменений теплового поля, возникающего при нарушении термодинамического равновесия объекта с окружающей средой, которое появляется на поверхности, и характер которого позволяет получить необходимую информацию. Метод теплового контроля базируется на взаимодействии теплового поля объекта с термодинамическими чувствительными элементами (термопара, фотоприёмник, жидкокристаллический элемент, болометр), которые преобразуют параметры поля (интенсивность, температурный градиент, контрастность, лучистость) в электрический сигнал регистрирующего устройства. В результате проведения эксперимента было подтверждено что термографический способ контроля может быть использован при обследовании стальных конструкций для качественной оценки скрытых дефектов и повреждений. В качестве измерительных приборов для проведения эксперимента использовались тепловизоры с различной разрешающей способностью матрицы ИК изображения, инфракрасный термогигрометр, люксметр. Во время проведения эксперимента не было выявлено принципиальной разницы применения тепловизоров с различными типами ИК матриц. При использовании более точного тепловизора Flir E8 теплограмма имела более четкое определение температуры поверхности по сравнению с Flir C2. Эта особенность может пригодиться для количественного определения дефектов, к примеру, глубины и размеров трещины под слоем краски, но принципиально, для качественного обнаружения дефектов и повреждений, использование более точного оборудования не является обязательным условием. Указаны проблемы, возникающие при использовании способа теплового неразрушающего контроля и возможные способы их решения. Авторы делают выводы о том, что способ термографического контроля может быть использован при обследовании стальных конструкций для качественной оценки наличия трещин. В значительной степени на качество термограмм влияет степень блеска поверхности исследуемого объекта, высокая степень блеска не позволяет получить достоверные данные, для снижения степени блеска поверхность исследуемого объекта необходимо нанесение специального покрытия с высоким коэффициентом излучения. 
Ключевые слова: стальные конструкции, трещина, термография, инфракрасная камера, неразрушающий контроль.

\title{
THE POSSIBILITY OF THERMOGRAPHIC CONTROL METHOD APPLICATION FOR DETECTION OF CRACKS IN STEEL STRUCTURES
}

Popadenko A.O., Master, popadenko@donnaba.edu.ua, ORCID:0000-0002-5615-7117

Kolesnichenko S.V., PhD., Associate Professor, Donbas national academy of civil engineering and architecture svk.mk15@gmail.com, ORCID: 0000-0001-5087-8354

\begin{abstract}
The paper discusses a possibility of using thermographic non-destructive testing to search for cracks in steel structures. The basis of non-destructive thermal control is the registration of changes in the thermal field that occurs when the thermodynamic balance of the object with the environment is disturbed, which appears on the surface and whose nature allows to obtain the necessary information. The method of thermal control is based on the interaction of the thermal field of the object with thermodynamic sensitive elements (thermocouple, photodetector, liquid crystal element, bolometer), which convert the field parameters (intensity, temperature gradient, contrast, radiance) into electrical signal of the recording device. As a result of the experiment, it was confirmed that the thermographic control method can be used in the examination of steel structures for a qualitative assessment of latent defects and damage. As measuring instruments for the experiment, thermal cameras with different resolutions of the IR image sensor, infrared thermohygrometer, and luxmeter were used. During the experiment, there was no fundamental difference of the use thermal cameras with different types of IR matrices. When using a more accurate Flir E8 thermal camera, the thermogram had a clearer definition of surface temperature compared to Flir C2. This feature can be used for the quantitative determination of defects, for example, the depth and size of a crack under a paint layer, but fundamentally, for the qualitative detection of defects and damage, the use of more accurate equipment is not a prerequisite. The problems arising when using the method of thermal non-destructive testing and possible methods for solving them are indicated. The authors conclude that the method of thermographic control can be used in the examination of steel structures for a qualitative assessment of the presence of cracks. To a large extent, the quality of thermograms is influenced by gloss degree of the surface of studied object, a high gloss degree does not allow reliable data to be obtained, to reduce the gloss degree, the surface of the examined object requires the application of a special coating with a high emissivity.
\end{abstract}

Keywords: steel structures, crack, thermography, infrared camera, non-destructive testing. 


\section{РОЗРАХУНОК ДЕРЕВ'ЯНОЇ РАМИ БУДІВЛІ $З$ УРАХУВАННЯМ ВЛАШТУВАННЯ НА ПОКРІВЛІ ЕЛЕМЕНТІВ АЛЬТЕРНАТИВНОЇ ЕНЕРГЇ̈}

Романенко С.М., старший викладач кафедри будівництва, romanesko666@gmail.com, ORCID ID: 0000-0002-0443-3896

Андрісвська Я.П., асистент кафедри будівництва, ДВНЗ «Херсонський державний аграрний університет» yanaandrievska321@gmail.com, ORCID ID: 0000-0003-3052-2515

Анотація. У статті наведені результати обстеження несучих конструкцій будівлі в комплексі. Обстеження проводилося візуальним і інструментальним методом у зв'язку 3 розташуванням сонячних панелей на даху будівлі. Визначено схеми і параметри зовнішніх впливів на дерев'яні частини об'єкта, в т.ч. фактично діючі постійні і тимчасові навантаження 3 урахуванням власної ваги матеріалів, конструктивних і технологічних особливостей об'єкта.

У зв’язку збільшенням навантаження проведено перевірочний розрахунок несучих конструкцій будівлі, розроблена розрахункова модель.

Дослідження виконано із застосуванням класичних розрахунків будівельної механіки та методів комп'ютерного моделюючого експерименту в програмному комплексі «Ліра САПР 2013».

Ключові слова: деревина, рама, зусилля, навантаження, несуча здатність

Вступ. Одним з першочергових завдань у розвитку України, є реалізація програми енергонезалежності, основна мета якої полягає у забезпеченні енергетичної безпеки i переходу до енергоефективного, енергоощадного використання та споживання енергоресурсів.

Використання нових технологічних та нетехнологічних інновацій поширено, як на виробничій стороні рівняння енергії (альтернативні джерела, нові передові технології енергозбереження) та на стороні споживання.

На сьогоднішній день $є$ ефективним рішення для суб’єктів підприємницької діяльності та виробництва це встановлення сонячних електростанцій на даху будівель та споруд.

При будівництві сільськогосподарських, громадських i промислових будівель поширеним та основним будівельним матеріалом для конструкцій покриття є цільна або клеєна деревина.

Вітчизняний i зарубіжний досвід показав, що найбільш доцільно застосовувати дерев'яні кроквяні конструкції, несучі конструкції у вигляді напівферм або полурам, ферм i рам при будівництві, через невелику масу конструкцій і малої механізації при збиранні каркасів.

В процесі експлуатації дерев'яні конструкції втрачають міцність, деформативні, тепло- і звукоізоляційні властивості, а також піддаються загниванню, грибковим захворюванням $\mathrm{i}$ тому, щоб продовжити їх термін служби, необхідно виконати ряд заходів по ліквідації вищевказаних недоліків.

У зв'язку зі зміною навантажень, зміною характеристик матеріалу i можливим розвитком тріщин на експлуатаційній стадії дерев'яні будівельні конструкції покриття будівель та споруд потребують підсилення або повної заміни.

Питання про підвищення несучої здатності конструкцій будівель і споруд шляхом їх підсилення є актуальним.

Аналіз останніх джерел досліджень та публікацій. Праці вчених В. С. Деревягина, Г. Г. Карлсена, М. Є. Кагана, В. Ф. Іванова, В. М. Коченова,Ю.М. Іванов, В.В. Фурсов, І. Баррет, Р. Фоші, П. Кроссман, Л. Нільсен і П. Хоффмайер та інші значно збагатили науку в області дерев'яних конструкцій. В роботах цих вчених розглядались питання теоретичного $\mathrm{i}$ 
експериментального дослідження тривалої міцності та довговічності цільної деревини. Такими вченими як Б.Н. Уголєв, В.М. Хрульов, Л.М. Ковальчук, Ю.Ю. Славік, А.Д. Ломакін, С.Б. Турковський, В.П. Ярцев вивчали питання довговічності клеєної деревини.

С.Г. Лехницький, А.М. Мітинський, С.А. Амбарцумян, Ю.С. Соболєв, Дж. Гудман, 3. Хашин, О. Хоффман, К. Норріс проведено теоретичне обгрунтування чисельних методів розрахунків дерев'яних конструкцій та досліджено кінцево-елементні моделі з урахуванням анізотропії властивостей деревини.

Вченими проведено колосальну роботу по визначенню різних видів дефектних станів експлуатованих дерев'яних конструкцій, причин їх появи, а також по розробці різних методів і способів відновлення і посилення дерев'яних конструкцій. Основні результати такої роботи відображені в працях М.Д. Бойко, В.В. Большакова, І.М. Гуськова, Г.Н. Зубарєва, В.Ф. Іванова, А.В. Калугіна, Г.Г. Карлсена, Л.М. Ковальчука, Т.А. Мальцева, Н.А. Мітюшина, Г.В. Свєнціцького, Ю.В. Сліцкоухова, А.В. Туркова, С.Б. Турківського, Г.А. Цвінгмана та інших вчених.

Серед зарубіжних слід виділити роботи - Bauman R., Gatz K., Haring H., Kollmann F., Larsen H., Lyon D.E., Mielczarek Z., Norris H. и др. др.

Постановка цілей і завдань досліджень. Метою дослідження є обстеження будівлі складу для визначення несучої здатності дерев'яних конструкцій після тривалої експлуатації і з урахуванням влаштування на покрівлі сонячних панелей, пропозиції щодо підсилення конструкцій та розрахунок. Дослідження виконано із застосуванням класичних розрахунків будівельної механіки та методів комп'ютерного моделюючого експерименту в програмному комплексі «Ліра САПР 2013», який алгоритмічно базується на методі кінцевих елементів.

Задачі дослідження:

- виконати аналіз конструкцій з цільної деревини після тривалої експлуатації;

- розроблення розрахункової моделі дерев'яної рами;

- розробити рекомендації з відновлення несучої здатності дерев'яних конструкцій;

- проаналізувати результати, отримані після перевірочних розрахунків.

Методика дослідження. Згідно результатів проведеного інженерно-технічного обстеження будівлі представлена загальна характеристика будівлі. [1-4]

Об'єктом обстеження є будівельні конструкції одноповерхової будівлі складу для зберігання зерна. Склад розташований в сільськогосподарському комплексі ХПП ПраТ «Херсонський КХП» за адресом: Херсонська обл., Білозерський район, с. Микільське, вул. Репринська, будинок 2-А. Будівля поділена на три протипожежні відсіки: зерносклад №1, зерносклад №2 та зерносклад №3 згідно технічного паспорту, представленого замовником. (Рис. 1).

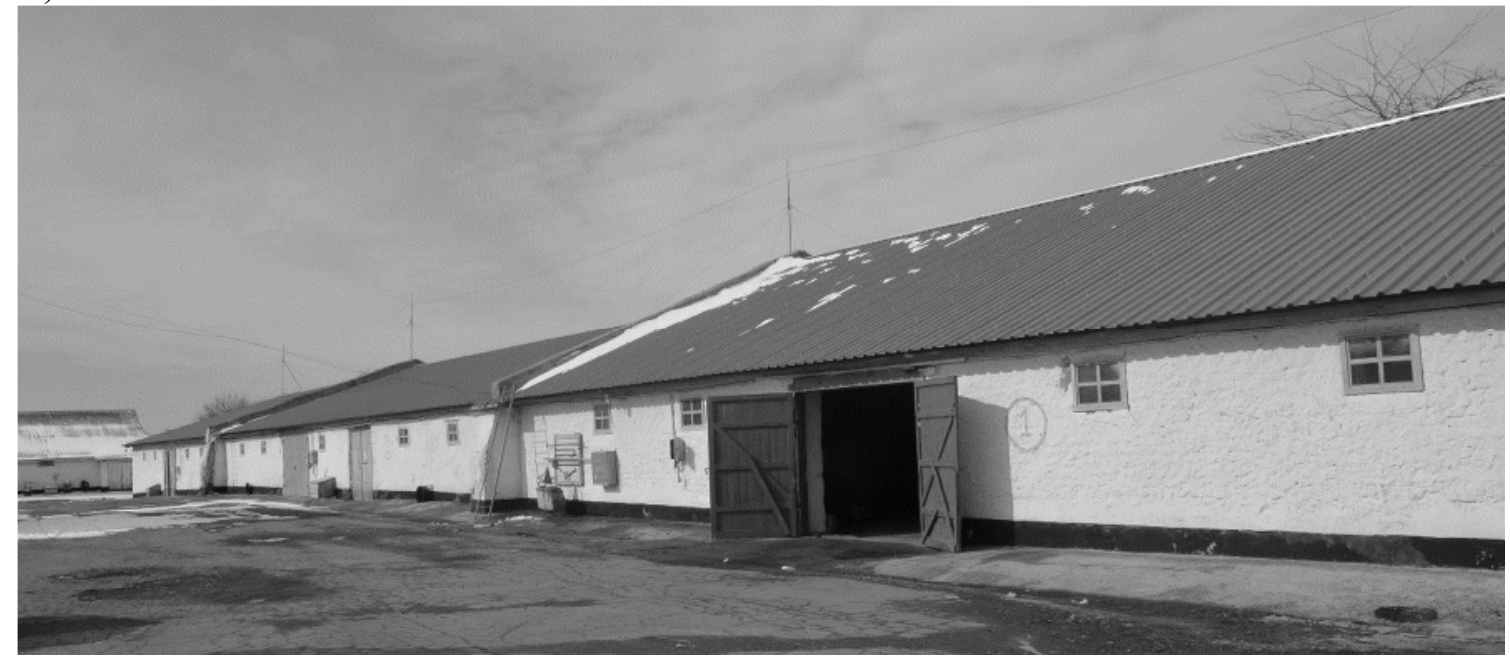

Рис. 1. Загальний вигляд та головний фасад будівлі 
Протипожежна стіна - брандмауер відокремлює одну частину будівлі від іншої на всю висоту та ширину, спирається на фундаменти і перевищує покрівлю будинку.

Згідно технічної документації зерновий склади № 3 побудован 1949 році, а зернові склади № 1,2 рік побудови будівель не визначен.

Конструктивна схема будівлі - неповний каркас. Будівля складу прямокутної форми 3 габаритними розмірами в плані: зерносклад №1 - 28,3×20,1 м; зерносклад №2 - 34,1х20,1м; зерносклад №3 - 28,2х20,1 м. Висота приміщень зернових складів становить 5,2 м.

Зовнішні стіни виконані з використанням бутової кладки з вапняку товщиною 750 мм. Висота зовнішніх стін складає 3,54 м. Кладка стін щільна міцна, вивітрювання розчину кладки відсутнє. Внутрішнє опорядження стін - цементно-піщана штукатурка, пофарбована.

Фундаменти - стрічкові із бутової кладки з вапняку. Окремо виконані фундаменти під суцільно дерев'яні стойки.

Колони - дерев'яні круглого суцільного перерізу. Крок колон в поздовжньому напрямі 5,7 м. Максимальна відстань між колонами у поперечному напрямі 8,7 м.

На момент обстеження візуально визначено що конструкція покрівлі і несучі елементи покрівлі (кроквяна нога) оновлені.

По виду конструкцій крокви наслонні, які виконані з дерев'яного брусу прямокутного перерізу. Крокви встановлені с кроком 60 см. Кроквяна нога складна. Стик двох елементів кроквяних ніг виконаний в місцях обпирання колон.

Нижні кінці кроквяних ніг опираються на зовнішні стіни. Кроквяні ноги підтримуються системою прогонів, стойок, підкосів. В якості стояків-опор служать дерев'яні колони внутрішнього каркаса.

Між верхніми кінцями кроквяних ніг затискають одну підвісну бабку з підкосами, до нижнього кінця якої підвішена за допомогою хомутів із сталі затяжка, яка опирається на прогін. Елементи дерев'яної ферми виконані з брусу і круглих колод.

Дах - двосхилий. Торець двосхилого даху вирішено у вигляді фронтону. Водостік неорганізований.

Покрівля виконана $з$ профільованого листа типу Н без лакофарбового покриття по ДСТУ Б В.2.6-9 по об'ємною кроквяній системі.

Ворота дерев'яні розсувні.

Віконні блоки - дерев'яні одинарної конструкції з листовим склом. Всередині приміщення на вікна встановлені металеві грати.

Перемички над прорізами - дерев’яні.

Підлога - бетонна по грунту.

Загальний вигляд дерев'яних конструкцій зерноскладу №1 представлено на рис. 2 та поперечний розріз будівлі на рис. 3.

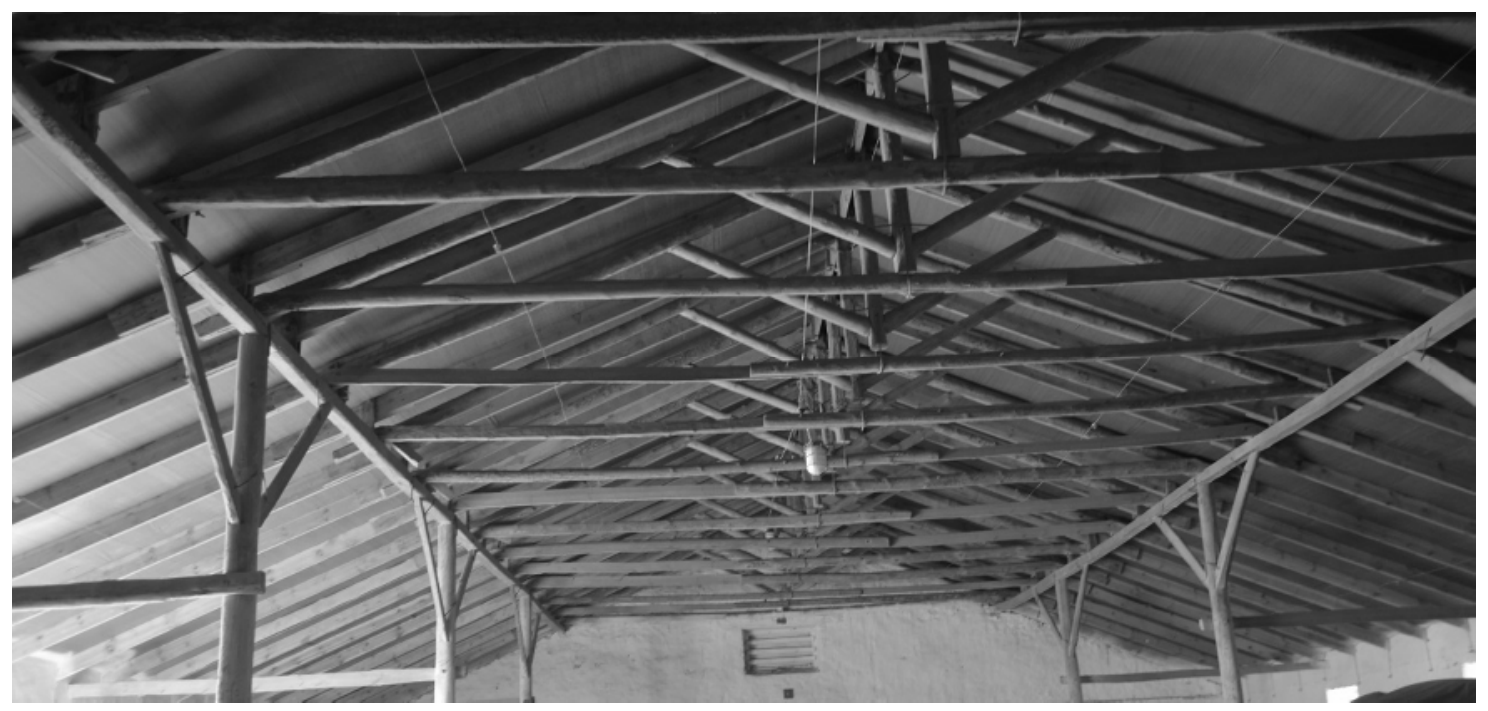


Рис. 2. Внутрішні несучі дерев’яні конструкції зерноскладу №1

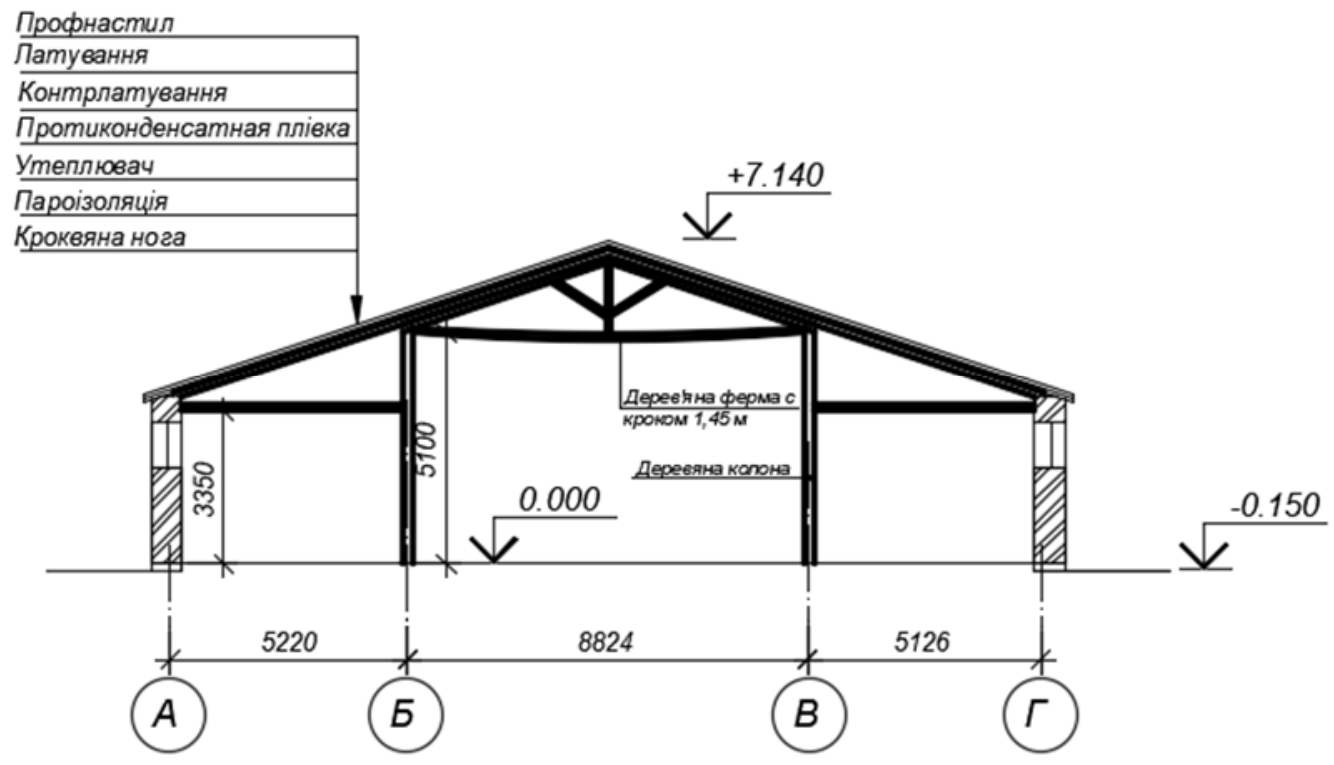

Рис. 3. Поперечний розріз будівлі зерноскладу №1

Після обстеження прийняте рішення про можливість використання існуючих конструкцій у подальшому після виконаних перевірочних розрахунків. Конструкції, які не задовольняють вимогам перевірних розрахунків, можуть бути підсилені з поновленням їх працездатності та підвищення несучої здатності за рахунок спеціальних заходів або замінені на нові. Основними способами ремонту і підсилення дерев'яних конструкцій $є$ [5]:

- збільшення поперечного перерізу окремих елементів конструкції;

- заміна ушкоджених дерев'яних елементів новими дерев'яними чи металевими;

- зміна конструктивної схеми всього каркаса або окремих елементів;

- зміна виду з'єднань елементів і конструкцій;

- регулювання напружень;

- установлення додаткових конструкцій чи робочих елементів без зміни схеми роботи конструкцій.

Кожен з цих методів може застосовуватися самостійно або в комбінації з іншим.

Результати досліджень. В результаті обстеження будівлі під час експлуатації було встановлено, що дерев'яні конструкції рами мають дефекти та пошкодження: тріщини в деревині елементів конструкцій; прогини елементів.

Для оцінки несучої здатності дерев’яних конструкцій каркасу будівлі зерноскладу №1 в сільськогосподарському комплексі ХПП ПраТ «Херсонський КХП» за адресом: Херсонська обл., Білозерський район, с. Микільське, вул. Репринська, будинок 2-А, згідно з нормами $[6,7]$ виконано розрахунок дерев'яної рами з застосуванням розрахункової моделі, яка 3 точністю передбачає реальну роботу конструкції. Розрахунок дерев'яної рами виконано у програмному комплексу «Ліра САПР 2013» [8] 3 використанням статичної моделі, яка враховує достовірну роботу конструкції та опор. Дерев'яні конструкції повинні задовольняти вимогам розрахунку за несучою здатністю і відповідності з заданими розрахунковими схемами. Перевірка несучої здатності і стійкості конструкцій виконана відповідно до діючого нормативного документа ДБН В. 2.6-161:2017 [9-11].

Навантаження і впливи враховувались при проектуванні конструкції з цілої деревини приймаються відповідно до ДБН В.1.2-2 з урахуванням класу навантаження за тривалістю діï.

Дерев'яні елементи круглого перерізу повинні відповідати вимогам ДСТУ EN 8443:2004, ДСТУ ЕNV 1927-2:2005, ДСТУ ЕN 1315-2-2001. 
При розрахунку елементів конструкцій враховувалось викривлення елементів та неоднорідність матеріалу.

Розрахунок дерев'яної рами виконувався у такій послідовності згідно 3 діючими нормами:

- встановлення розрахункової схеми рами;

- визначення та збір навантаження;

- визначення розрахункових зусиль в елементах рами;

- підбір поперечних перерізів елементів.

Розрахункова схема з доданими навантаженнями і переміщень уздовж осі Z, X від розрахункових навантажень представлена на рис. 4-8.

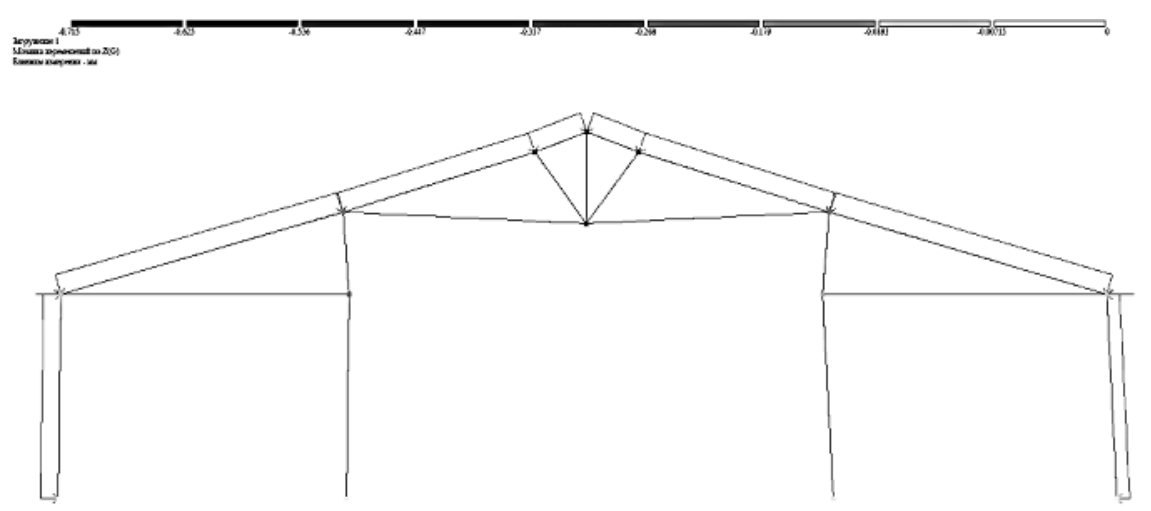

臸

Рис. 4. Переміщення уздовж осі Z від розрахункових навантажень

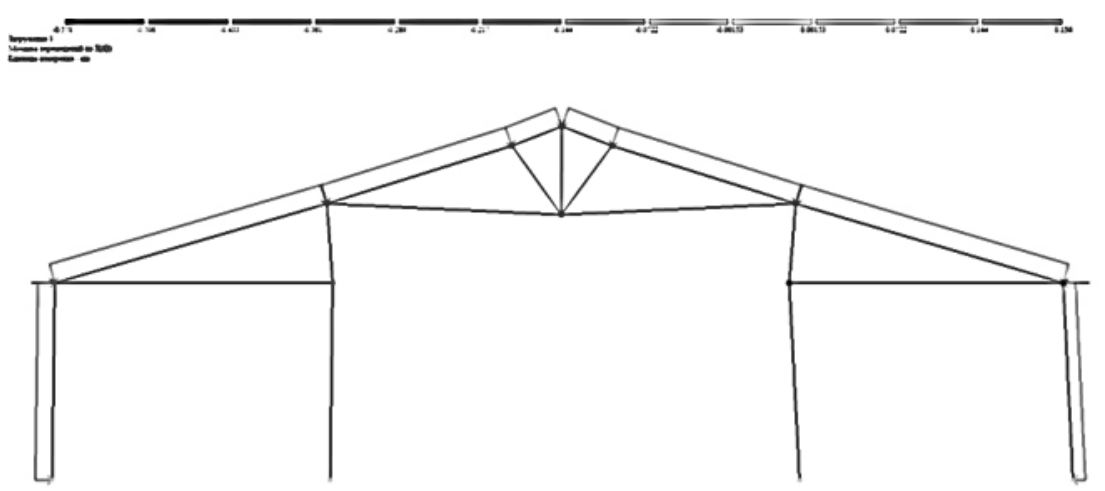

约

Рис. 5. Переміщення уздовж осі X від розрахункових навантажень

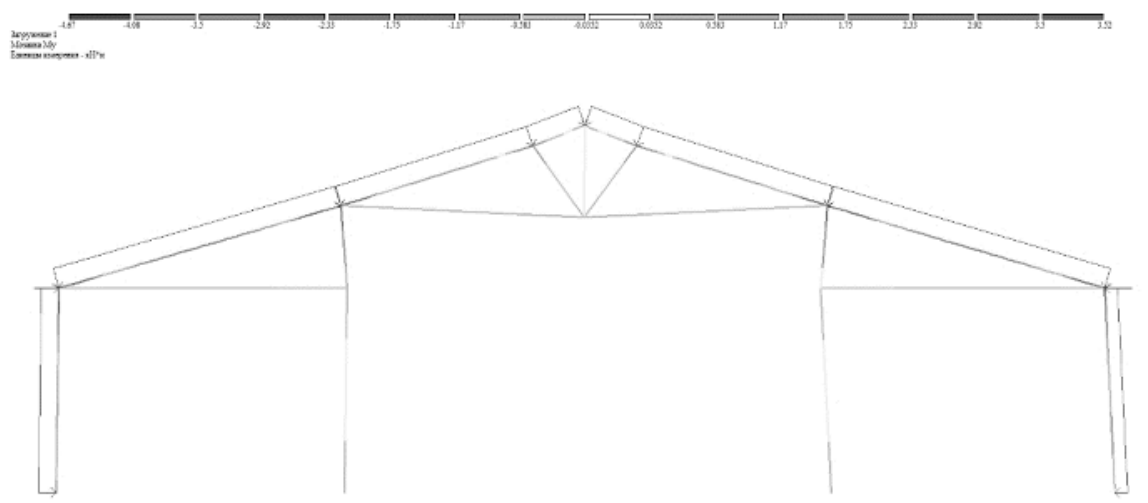


Рис. 6. Розрахункові моменти від навантажень в елементах дерев'яної рами

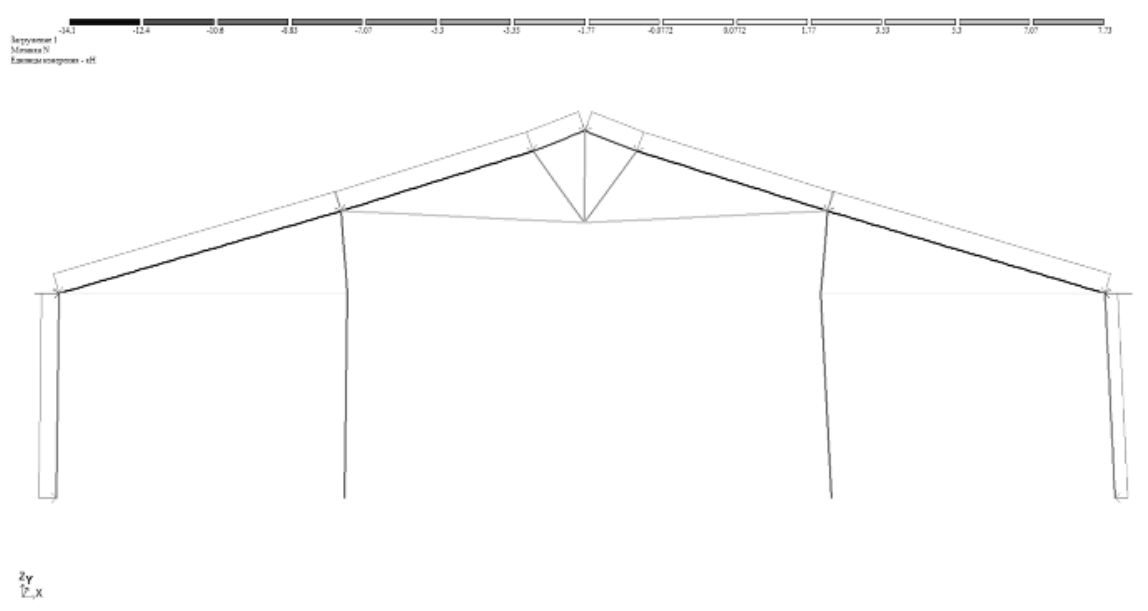

Рис 7. Розрахункові зусилля від навантажень в елементах дерев’яної рами

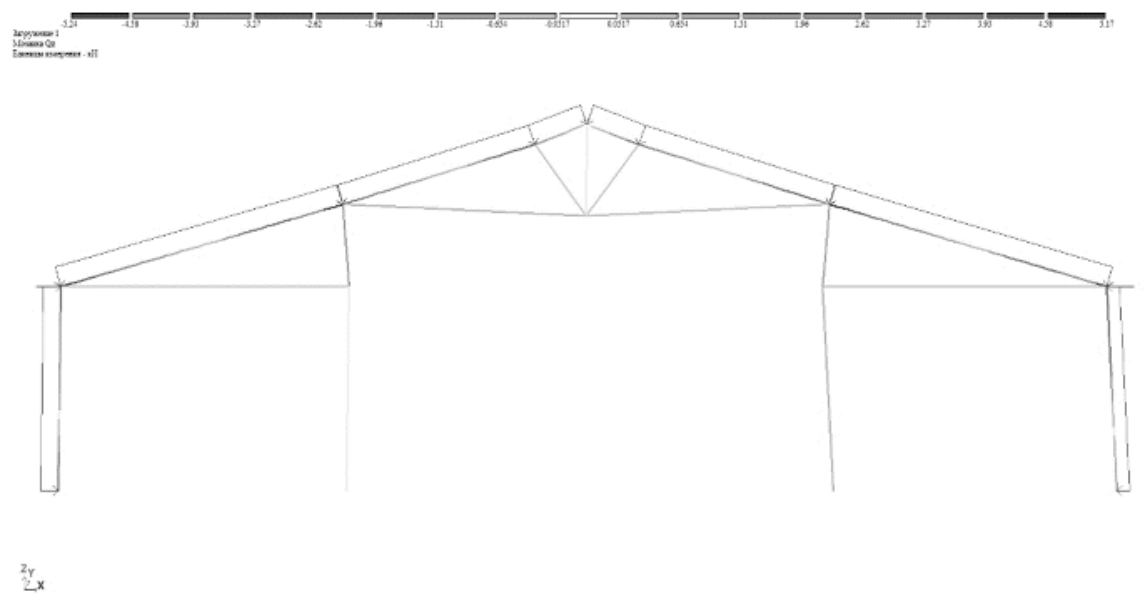

Рис. 8. Поперечні сили від розрахункових експлуатаційних навантажень в елементах дерев'яної рами

Переріз існуючих елементів дерев'яної рами задовольняє згідно розрахунку.

Висновок. Аналіз результатів та натурних обстежень дерев'яних конструкцій та їх елементів в зерноскладі №1 після експлуатації понад 75 років в змінних температурно вологісних умовах показав, що несуча здатність та надійність несучих дерев'яних конструкцій незмінна не тільки при наявності різних пошкоджень та дефектів, але й внаслідок природного старіння деревини.

Результати проведених досліджень використані при складанні рекомендацій по відновленню властивостей конструкцій з цільної деревини після їх тривалої експлуатації.

Отримані дані впроваджені в будівельну практику при капітальному ремонті зернового складу №1.

\section{Література}

1. ДСТУ-Н Б В.1.2-18:2016. Настанова щодо обстеження будівель і споруд для визначення та оцінки їх технічного стану. [Чинний $з$ 2017-04-01]. Вид. офіц. Київ : ДП "УкрНДНЦ", 2017. 32 с.

2. Клименко С.В. Технічний стан будівель та споруд: монографія. Одеса: ОДАБА, 2010. $316 \mathrm{c}$. 
3. Барашиков А. Я., Малишев О.М. Оцінювання технічного стану будівель та інженерних споруд: Навч. посіб. для студ. вищих навч. закл. - К.: Основа, 2008. - 320 с. ISBN: 978-966-699-399-4

4. Гладишев Д. Г., Гладишев Г. М. Дослідження технічного стану будівель, споруд та їхніх елементів: монографія. Нац. ун-т «Львів. політехніка». - Л. : Вид-во Львів. політехніки, 2012. - 303 с. ISBN: 978-617-607-201-0

5. ДСТУ Б В.3.1-2:2016 Ремонт і підсилення несучих і огороджувальних будівельних конструкцій та основ будівель та споруд. [чинний з 2017-04-01] Вид. офіц. Київ : ДП «УкрНДНЦ», 2017. 67 с.

6. ДБН В. 1.2-14-2018. Загальні принципи забезпечення надійності та конструктивної безпеки будівель та споруд. [Чинний з 2019-01-01]. Вид. офіц. Київ : Мінрегіонбуд України, 2018. $29 \mathrm{c}$.

7. ДБН В.1.2-9-2008. Система забезпечення надійності та безпеки будівельних об єктів. Основні вимоги до будівель і споруд. Безпека експлуатації. [Чинний з 2008-10-01 ]. Вид. офіц. Київ : Мінрегіонбуд України, 2008. 21с.

8. Городецкий Д.А., Барабаш М.С., Водопьянов Р.Ю., Титок В.П., Артамонова А.Е. Учебное пособие програмный комплекс Лира-Сапр 2013: учебное пособие. Москва: Электронное издание, 2013. 376 с.

9. ДБН В.2.6-161:2017 Дерев’яні конструкції. Основні положення. [Наказ Міністерства регіонального розвитку, будівництва та житлово-комунального господарства України від 06.06.2017 p. № 140, чинні з першого числа місяця, що настає через 90 днів 3 дня їх опублікування в офіційному друкованому виданні Міністерства "Інформаційний бюлетень Міністерства регіонального розвитку, будівництва та житлово-комунального господарства України"] Вид. офіц. Київ : Міністерство регіонального розвитку, будівництва та житловокомунального господарства України, 2017. 67 с.

10. А. А. Ягмур, Я. В. Назім, Є. В. Шевченко, С. М. Бакаєв Приклади розрахунку конструкцій з дерева і пластмас : Навч. посіб. Донбас. нац. акад. буд-ва і архіт. - Макіївка, 2004. $120 \mathrm{c}$.

11. В. З. Кліменко, Д. В. Михайловський, М. С. Коваленко, І. О. Скляров Дерев'яні конструкції. Арки : навч. посіб. для студ. напряму підготов. "Архітектура" Київ. нац. ун-т буд-ва і архіт. - К. : КНУБА, 2012. 86 с.

\section{References}

[1] DSTU-N B V.1.2-18:2016. Nastanova schodo obstezhennya budIvel I sporud dlya viznachennya ta otsInki Yih tehnIchnogo stanu. [Chinniy z 2017-04-01]. Vid. oflts. KiYiv : DP "UkrNDNTs", 2017. 32 s.

[2] Klimenko E.V. TehnIchniy stan budIvel ta sporud: monograflya. Odesa: ODABA, 2010. 316 s.

[3] Barashikov A. Ya., Malishev O.M. OtsInyuvannya tehnIchnogo stanu budIvel ta Inzhenernih sporud: Navch. posIb. dlya stud. vischih navch. zakl. - K.: Osnova, 2008. - 320 s. ISBN: 978966-699-399-4

[4] Gladishev D. G., Gladishev G. M. DoslIdzhennya tehnIchnogo stanu budIvel, sporud ta YihnIh elementIv: monograflya. Nats. un-t «LvIv. polItehnIka». — L. : Vid-vo LvIv. polItehnIki, 2012. - 303 s. ISBN: 978-617-607-201-0

[5] DSTU B V.3.1-2:2016 Remont I pIdsilennya nesuchih I ogorodzhuvalnih budIvelnih konstruktsIy ta osnov budIvel ta sporud. [chinniy z 2017-04-01] Vid. oflts. KiYiv : DP «UkrNDNTs», 2017.67 s.

[6] DBN V. 1.2-14-2018. ZagalnI printsipi zabezpechennya nadIynostI ta konstruktivnoYi bezpeki budIvel ta sporud. [Chinniy z 2019-01-01]. Vid. ofIts. KiYiv : MInregIonbud UkraYini, 2018. $29 \mathrm{~s}$. 
[7] DBN V.1.2-9-2008. Sistema zabezpechennya nadIynostI ta bezpeki budIvelnih ob'EktIv. OsnovnI vimogi do budIvel I sporud. Bezpeka ekspluatatsIYi. [Chinniy z 2008-10-01 ]. Vid. oflts. KiYiv : MInregIonbud UkraYini, 2008. 21s.

[8] Gorodetskiy D.A., Barabash M.S., Vodopyanov R.Yu., Titok V.P., Artamonova A.E. Uchebnoe posobie programnyiy kompleks Lira-Sapr 2013: uchebnoe posobie. Moskva: Elektronnoe izdanie, 2013. $376 \mathrm{~s}$.

[9] DBN V.2.6-161:2017 Derev'yanI konstruktsIYi. OsnovnI polozhennya. [Nakaz MInIsterstva regIonalnogo rozvitku, budIvnitstva ta zhitlovo-komunalnogo gospodarstva UkraYini vId 06.06.2017 r. \# 140, chinnI z pershogo chisla mIsyatsya, scho nastaE cherez $90 \mathrm{dnIv}$ z dnya Yih opublIkuvannya $\mathrm{v}$ ofltsIynomu drukovanomu vidannI MInIsterstva "InformatsIyniy byuleten MInIsterstva regIonalnogo rozvitku, budIvnitstva ta zhitlovo-komunalnogo gospodarstva UkraYini"] Vid. oflts. KiYiv : MInIsterstvo regIonalnogo rozvitku, budIvnitstva ta zhitlovo-komunalnogo gospodarstva UkraYini, 2017. $67 \mathrm{~s}$.

[10] A. A. Yagmur, Ya. V. NazIm, E. V. Shevchenko, S. M. BakaEv Prikladi rozrahunku konstruktsIy z dereva I plastmas : Navch. posIb. Donbas. nats. akad. bud-va I arhIt. MakIYivka, 2004. $120 \mathrm{c}$.

[11] V. Z. KlImenko, D. V. Mihaylovskiy, M. S. Kovalenko, I. O. Sklyarov Derev'yanI konstruktsIYi. Arki : navch. posIb. dlya stud. napryamu pIdgotov. "ArhItektura" KiYiv. nats. un-t bud-va I arhIt. - K. : KNUBA, 2012. 86 c.

\section{РАСЧЕТ ДЕРЕВЯННОЙ РАМЫ ЗДАНИЯ С УЧЕТОМ УСТРОЙСТВО НА КРЫШЕ ЭЛЕМЕНТОВ АЛЬТЕРНАТИВНОЙ ЭНЕРГИИ}

Романенко С.Н., старший преподаватель кафедры строительства, romanesko666@gmail.com, ORCID ID: 0000-0002-0443-3896

Андриевская Я.П., ассистент кафедры строительства, Херсонский государственный аграрный университет yanaandrievska321@gmail.com, ORCID ID: 0000-0003-3052-2515

\footnotetext{
Аннотация. Одной из задач в развитии Украины, является реализация программы энергонезависимости. Использование новых технологических и нетехнологических инноваций распространено, как на производственной стороне сравнения энергии (альтернативные источники, новые передовые технологии энергосбережения) так и на стороне потребителя.

На сегодняшний день является эффективным решение для субъектов предпринимательской деятельности и производства - это установка солнечных электростанций на крыше зданий и сооружений.

В статье приведены результаты обследования визуальным и инструментальным методом в связи с расположением солнечных панелей на крыше здания. Определены схемы и параметры внешних воздействий на деревянные части объекта, в т.ч. фактически действующие постоянные и временные нагрузки с учетом собственного веса материалов, конструктивных и технологических особенностей объекта.

В связи увеличением нагрузки проведено проверочный расчет несущих деревянных конструкций здания, разработана расчетная модель.

Исследование выполнено с применением классических расчетов строительной механики и методов компьютерного моделирующего эксперимента в программном комплексе «Лира САПР 2013».

Расчет деревянной рамы выполнялся в такой последовательности согласно действующим нормам:

- установление расчетной схемы рамы;

- определение и сбор нагрузки;

- определение расчетных усилий в элементах рамы;
} 
- подбор поперечных сечений элементов.

Анализ результатов и натурных обследований деревянных конструкций и их элементов в здании зерноскладе №1 после эксплуатации более 75 лет в переменных температурно влажностных условиях показал, что несущая способность и надежность несущих деревянных конструкций неизменна не только при наличии различных повреждений и дефектов, но и вследствие естественного старения древесины.

Результаты проведенных исследований использованы при составлении рекомендаций по восстановлению свойств конструкций из цельной древесины после их длительной эксплуатации.

Ключевые слова: древесина, рама, усилие, нагрузка, несущая способность

\title{
CALCULATION OF A WOODEN FRAME OF A BUILDING TAKING INTO ACCOUNT THE DEVICE ON THE ROOF OF ALTERNATIVE ENERGY ELEMENTS
}

\author{
Romanenko S.M., senior lecturer department of Construction, \\ romanesko666@gmail.com, ORCID ID: 0000-0002-0443-3896 \\ Andriievska Y.P., assistant department of Construction, \\ Kherson State Agrarian University \\ yanaandrievska321@gmail.com, ORCID ID: 0000-0003-3052-2515
}

\begin{abstract}
One of the tasks in the development of Ukraine is the implementation of the energy independence program. The use of new technological and non-technological innovations is widespread both on the production side of energy comparison (alternative sources, new advanced energy saving technologies) and also on the consumer side.

An effective solution for business and production entities is the installation of solar power plants on the roof of buildings and structures at today.

In the article presents the results of the examination by visual and instrumental method in connection with the location of solar panels on the roof of the building. The schemes and parameters of external influences on the wooden parts of the object, including actual permanent and temporary loads, taking into account the sole weight of materials, design and technological features of the object.

Due to the increased of load was verification calculation of the load-bearing wooden structures of the building and was developed a calculation model.

The investigation was performed using classical calculations of structural mechanics and the methods of a computer simulation experiment in the software package "Lira CAD 2013".

The calculation of the wooden frame was carried out in the following sequence in accordance with applicable standards:

- the establishment of the design scheme of the frame;

- definition and collection of the load;

- determination of the design efforts in the frame elements;

- selection of cross sections of the elements.

Analysis of the results and field surveys of wooden structures and their elements in the building of grain warehouse No.1 after operation for the more than 75 years in a variable the temperature and humidity conditions is showed that the bearing capacity and reliability of the bearing wooden structures is unchanged not only in the presence of various damage and defects, but also due to the natural aging wood.

The results of the investigation were used to draw up the recommendations for restoring the properties of solid wood structures after their long-term operation.
\end{abstract}

Key words: wood, frame, an effort, load, bearing capacity 


\title{
ОЦЕНКА НАПРЯЖЕННО-ДЕФОРМИРОВАННОГО СОСТОЯНИЯ ФЕРМ ПОКРЫТИЙ ОДНОЭТАЖНЫХ ПРОМЫШЛЕННЫХ ЗДАНИЙ В ТОРЦЕВЫХ СВЯЗЕВЫХ БЛОКАХ С УЧЕТОМ ВЕТРОВОГО ДАВЛЕНИЯ В ТОРЕЦ ЗДАНИЯ
}

\author{
Сингаевский П.М., к.Т.н., доцент, \\ mdipk@ukr.net, ORCID: 0000-0003-1268-414X \\ Купченко Ю.В., к.Т.Н., доцент, \\ steelconpro@gmail.com, ORCID: 0000-0003-1480-6884 \\ Одесская государственная академия строительства и архитектуры
}

\begin{abstract}
Аннотация. В статье авторы исследуют вопрос влияния ветровой нагрузки в торец здания на напряженно-деформированное состояние ферм покрытия в торцевых связевых блоках. Традиционно, для восприятия ветрового давления в торец здания, в уровне нижних поясов ферм покрытия, посредством листовых шарниров на фахверковых колоннах устраивались горизонтальные связевые фермы. Поясами этих связевых ферм были нижние пояса самих ферм покрытия, а решетка проектировалась дополнительно. Далее, опорные реакции горизонтальных связевых ферм от ветровой нагрузки, через связи в плоскости колонн, передавались на фундамент. Однако, вопрос о том, что нижний пояс фермы покрытия выполняет функции пояса и связевой фермы и что усилия от вертикальной нагрузки в нем суммируются - не рассматривался.

Ключевые слова: ферма покрытия, листовой шарнир, связевой блок, нагрузка, опорная реакция, фахверк.
\end{abstract}

Введение. Авторы этой работы делают попытку оценки влияния ветрового давления в торец промздания на напряженно-деформированное состояние ферм покрытия в торцевых связевых блоках.

Анализ последних исследований и публикаций. Примеров публикаций в литературных источниках оценки влияния ветрового давления в торец здания на напряженно-деформированное состояние ферм покрытий в связевых торцевых блоках не обнаружено.

Целью работы является разработка методики количественной оценки влияния ветрового давления в торец промзданий на напряженно-деформированное состояние ферм покрытия в торцевых связевых блоках.

Результаты исследований. Определим усилия в связевых фермах по нижним поясам ферм покрытия от единичных сосредоточенных сил ветрового давления в торец промздания, приложенных в узлах нижнего пояса стропильных ферм (в уровне листовых шарниров на фахверковых колоннах по торцам здания).

На рис. 1 приведены геометрические схемы связевых ферм по нижним поясам ферм покрытия с усилиями в их элементах от единичной узловой нагрузки ветрового давления в торец промздания для типовых пролетов 18, 24, 30 и 36 м. Располагая единичными усилиями в элементах связевых ферм для любых типовых пролетов легко оценить влияние ветрового давления в торец промздания на напряженно-деформированное состояние ферм покрытия в связевых торцевых блоках.

Исследование проводим для промздания со следующими исходными данными:

1. Район строительства - г. Краматорск;

2. Пролет рамы $L=36$;

3. Шаг рам $B=6 \mathrm{~m}$;

4. Шаг колонн торцевого фахверка $B_{\phi}=6 \mathrm{~m}$;

5. Характеристическое значение ветрового давления $w_{0}=47 \mathrm{\kappa H} / \mathrm{s}^{2}$ [2];

6. Высота помещения цеха $H_{0}=12 \mathrm{~m}$; 
7. $\gamma_{f m}=1.035$ - коэффициент надежности по предельному расчетному значению ветровой нагрузки [2];

8. $\gamma_{n}=0.95$ - коэффициент надежности по назначению [4];

9. $C_{h 1}$ - коэффициент высоты сооружения [2], на высоте $0.5 \cdot H_{0}=0.5 \cdot 12=6$ м значение $C_{h 1}=1.65$

10. $C_{h 2}$ - коэффициент высоты сооружения [2], на высоте $H_{0}+h_{\phi}=12+3.5=15.5 \mathrm{M}$ значение $C_{h 2}=2.0$;

11. $h_{\phi}=3.5$ - высота фермы покрытия с ориентировочной высотой парапетной стенки;

12. $R_{y}=240$ MПа - расчетное сопротивление стали принятого класса прочности [1].
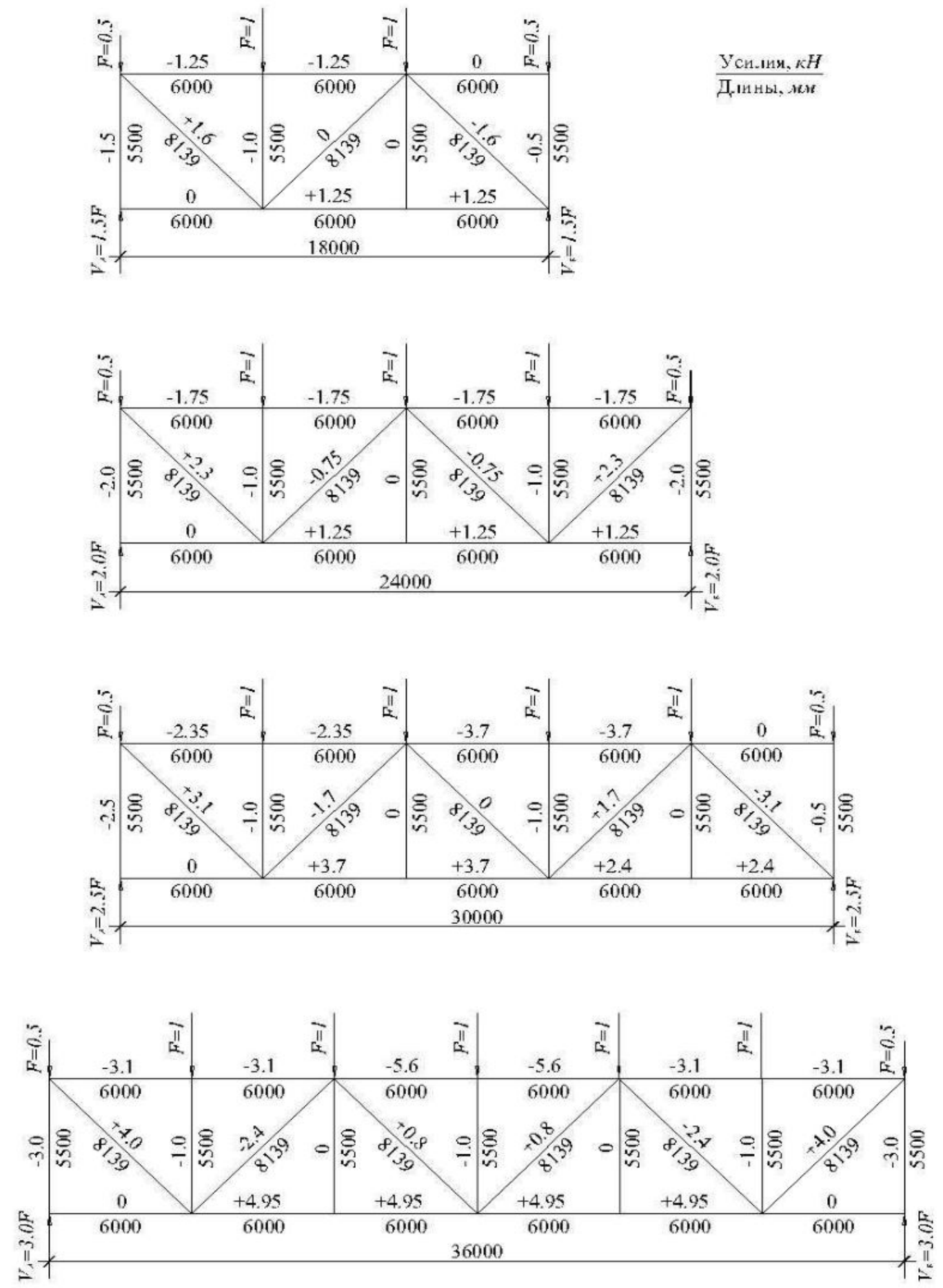

Рис. 1. Схема связей по нижним поясам ферм и усилий в их элементах от единичных узловых сил ветрового давления в торец одноэтажного промздания для пролетов $18,24,30$ и 36 м 
Тогда фактическое узловое ветровое давление в торец здания (рис. 2) будет:

$F=w_{0} \cdot \gamma_{f m} \cdot \gamma_{n} \cdot 0.5 \cdot\left(C_{h 1}+C_{h 2}\right) \cdot B_{\phi} \cdot\left(0.5 \cdot H_{0}+h_{\phi}\right)=$

$$
=0.47 \cdot 1.035 \cdot 0.95 \cdot 0.5 \cdot(1.65+2.0) \cdot 6 \cdot(0.5 \cdot 12+3.5)=48.1 \mathrm{kH} \text {. }
$$

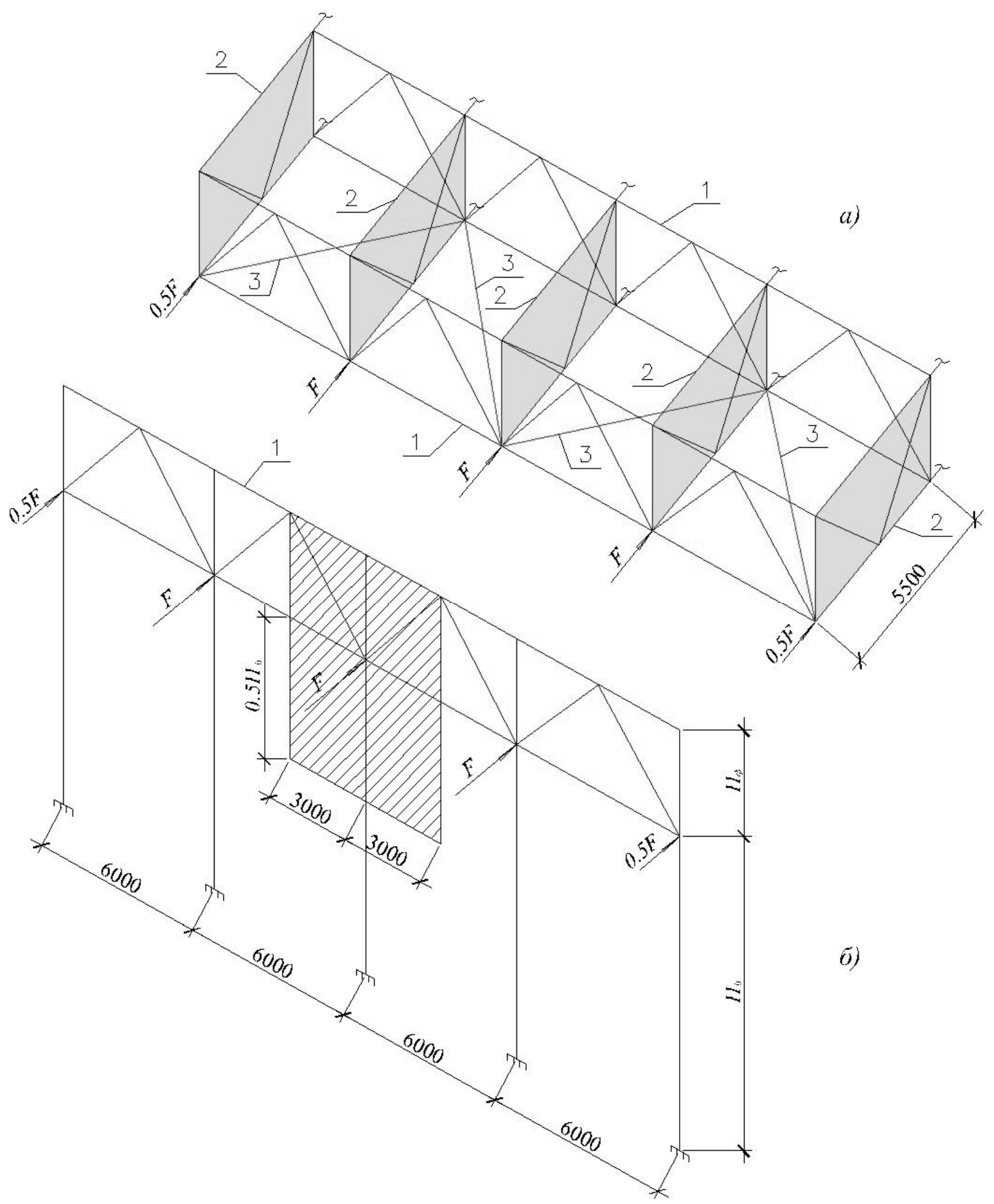

Рис. 2. Схема распределения ветрового давления в торец промздания по конструкциям каркаса

$a$ - схема торцевого связевого блока; $\sigma$ - доля ветрового давления в торец промздания, приходящаяся в уровень горизонтальной связевой фермы по нижним поясам ферм покрытия 1 - фермы покрытия; 2 - вертикальные связи между фермами; 3 - раскосы горизонтальной связевой фермы по нижним поясам ферм покрытия 
Для связевой фермы пролетом 36 м (рис. 1) максимальное растягивающее усилие в поясе от единичной горизонтальной узловой нагрузки соответствует 4.95 , а фактическое $4.95 \cdot F=4.95 \cdot 48.1=238.1 \kappa H$. Усилие в нижнем поясе фермы покрытия в этом примере составляет $1104.5 \kappa H$, а сечение было принято из Т 17.5 ШТ1, $A=47.5 \mathrm{~cm}^{2}$, условие прочности $N /\left(A \cdot R_{y}\right)=1104.5 /(47.5 \cdot 24)=0.97<1$.

Увеличение усилия в нижнем поясе ферм покрытия в связевом торцевом блоке за счет ветрового давления в торец промздания на величину $238.1 \kappa H$ привело к суммарному $N=1104.5 \kappa H+238.1 \kappa H=1324.6 \kappa H$.

Следует заметить, что функцию пояса связевой фермы выполняет сам нижний пояс фермы покрытия, сечение которого в примере принято из т 17.5 ШТ1 с площадью сечения $A=47.5 \mathrm{~cm}^{2}$. Совмещение двух функций в одном элементе привело к изменению напряженного состояния $N /\left(A \cdot R_{y}\right)=1324.6 /(47.5 \cdot 24)=1.27>1$.

\section{Выводы:}

1. К фермам покрытия промышленных зданий в торцевых связевых блоках следует особый подход в оценке напряженно-деформированного состояния в них.

2. Предлагаемая методика позволяет просто дать оценку напряженнодеформированному состоянию ферм покрытия типовых пролетов промзданий в связевых торцевых блоках.

\section{Литература}

1. ДБН В.2.6 - 198:2014. Сталеві конструкції. Норми проектування. - [чинні від 2015-01-01]. - К.: Мінрегіон України, 2014. - 199 с. (Державні будівельні норми України).

2. ДБН В.1.2-2:2006. Навантаження і впливи. Норми проектування. - [чинні від 200701-01]. - К.: Мінбуд України, 2006. - 75 с. (Державні будівельні норми України).

3. Нілов О.О. Металеві конструкції / О.О. Нілов, В.О. Пермяков, С.І. Білик, О.В. Шимановський, І.Д. Бєлов, Л.І. Лавриненко, В.О. Володимирський / - К.: Сталь, 2010. 869 c.

4. ДБН В.1.2-14:2018. Система забезпечення надійності та безпеки будівельних об'єктів. Загальні принципи забезпечення надійності та конструктивної безпеки будівель i споруд. - [чинні від 2019-01-01]. - К.: Мінрегіон України, 2018. - 30 с. (Державні будівельні норми України).

\section{References}

[1] DBN V.2.6-198:2014. Stal'nyye konstruktsii. Normy proyektirovaniya [chynni vid 2015-0101]. K.: Minrehion Ukrainy, 2014.

[2] DBN V.1.2-2:2006. Navantazhennia i vplyvy. Normy proyektirovaniya [chynni vid 2007-0101]. K.: Minbud Ukrainy, 2006.

[3] O.O. Nilov, V.O. Permyakov, S.I.Bilyk, O.V. Shymanovs'kyy, I.D. Byelov, L.I. Lavrynenko, V.O. Volodymyrs'kyy, Metalevi konstruktsiyi, Kyev: Stal', 2010.

[4] DBN V.1.2-14:2018. Systema zabezpechennya nadiynosti ta bezpeky budivel'nykh ob"yektiv. Zahal'ni pryntsypy zabezpechennya nadiynosti ta konstruktyvnoyi bezpeky budivel' $i$ sporud [chynni vid 2019-01-01]. K.: Minrehion Ukrainy, 2018. 


\title{
ОЦНКА НАПРУЖЕНО-ДЕФОРМОВАНОГО СТАНУ ФЕРМ ПОКРИТТІВ ОДНОПОВЕРХОВИХ ПРОМИСЛОВИХ БУДІВЕЛЬ В ТОРЦЕВИХ В'ЯЗЕВИХ БЛОКАХ 3 ВРАХУВАННЯМ ВІТРОВОГО ТИСКУ В ТОРЕЦЬ БУДІВЛІ
}

\author{
Сінгаївський П.М., к.т.н., доцент, \\ mdipk@ukr.net, ORCID: 0000-0003-1268-414X \\ Купченко Ю.В., к.т.н., доцент, \\ steelconpro@gmail.com, ORCID: 0000-0003-1480-6884 \\ Одеська державна академія будівництва та архітектури
}

\begin{abstract}
Анотація. У статті автори досліджують питання впливу вітрового навантаження у торець будівлі на напружено-деформований стан ферм покриття у торцевих в'язевих блоках. Традиційно, для сприйняття вітрового тиску у торець промислової будівлі, в рівні нижніх поясів ферм покриття, за допомогою листових шарнірів на фахверкових колонах улаштовувались горизонтальні в'язеві ферми. Поясами цих в'язевих ферм були нижні пояси самих ферм покриття, a решітка проектувалась додатково. Далі, опорні реакції горизонтальних в’язевих ферм від вітрового навантаження, через в'язи у площині колон, передавались на фундаменти.
\end{abstract}

При цьому, питання про те, що нижній пояс ферм покриття виконує функцію пояса в'язевої ферми і що зусилля від вертикального навантаження і вітрового горизонтального навантаження підсумовуються - не розглядалось. Тому необхідно оцінити вплив вітрового тиску в торець промислової будівлі на напружено-деформований стан ферм покриття в торцевих в'язевих блоках.

Авторами розробляється методика кількісної оцінки впливу вітрового тиску в торець промислових будівель на напружено-деформований стан ферм покриття в торцевих в'язевих блоках.

Визначаються зусилля у в'язевих фермах по нижніх поясах ферм покриття від одиничних зосереджених сил вітрового тиску в торець промислової будівлі, які прикладені у вузлах нижнього поясу кроквяних ферм - в рівні листових шарнірів на фахверкових колонах по торцях будівлі.

Розглядаються геометричні схеми в'язевих ферм по нижніх поясах ферм покриття із зусиллями в їх елементах від одиничного вузлового навантаження вітрового тиску в торець промислової будівлі для типових прольотів 18, 24, 30 і 36 м. Отримавши одиничні зусилля в елементах в'язевих ферм для будь-яких типових прольотів легко оцінити вплив вітрового тиску на напружено-деформований стан ферм покриття у в'язевих торцевих блоках.

Для прикладу розглянута промислова будівля прольотом 36 м і кроком поперечних рам 6 м, розташована в м. Краматорську. Для в'язевої ферми прольотом 36 м знайдено максимальне зусилля розтягу в поясі від одиничного горизонтального вузлового навантаження і фактичне.

Слід зауважити, що функцію поясу в'язевої ферми виконує сам нижній пояс ферми покриття, запас міцності якого 3 врахуванням розрахункового граничного навантаження склав 3\%. Але зусилля в нижньому поясі ферм покриття у в'язевому торцевому блоці збільшується за рахунок вітрового тиску в торець будівлі. Поєднання двох функцій в елементі нижнього поясу приводить до зміни напруженого стану - перенапруження в нижньому поясі склало $27 \%$.

До ферм покриття промислових будівель в торцевих в'язевих блоках необхідний особливий підхід в оцінці напружено-деформованого стану в них.

Запропонована методика дозволяє просто дати оцінку напружено-деформованому стану ферм покриття типових прольотів промислових будівель у в'язевих торцевих блоках.

Ключові слова: ферма покриття, листовий шарнір, в'язевий блок, навантаження, опорна реакція, фахверк. 


\title{
EVALUATION OF THE STRESSED-STRAIN CONDITION OF THE ROOF TRUSSES OF ONE-STOREYED INDUSTRIAL BUILDING IN THE END BRACE BLOCKS TAKING INTO ACCOUNT THE WIND PRESSURE AT THE FLANK OF THE BUILDING
}

\author{
Singayevsky P. M., PhD., Assistant Professor, \\ mdipk@ukr.net, ORCID: 0000-0003-1268-414X \\ Kupchenko Y.V., PhD., Assistant Professor, \\ steelconpro@gmail.com, ORCID: 0000-0003-1480-6884 \\ Odessa State Academy of Civil Engineering and Architecture
}

\begin{abstract}
In the article, the authors investigate the effect of the wind load at the frank of the building on the stress-strain state of the roof trusses in the end brace blocks. Traditionally, to perceive the wind pressure to the frank of the building, in the lower zones of the roof trusses, horizontal joint trusses were arranged on the half-timbered columns by means of sheet hinges. The belts of these brace trusses were the lower belts of the roof trusses themselves, and the grid was designed additionally. Further, the support reactions of the horizontal brace trusses from the wind load, through braces in the plane of the columns, were transferred to the foundation.

However, the question that the lower belt of the roof truss performs the functions of a belt and a brace truss and that the forces from the vertical load are combined in it, was not considered. Therefore, it is necessary to evaluate the effect of wind pressure at the flank of an industrial building on the stress-strain state of brace trusses in end brace blocks.

The authors are developing a method for the quantitative assessment of the effect of wind pressure on the flank of industrial buildings on the stress-strain state of roof trusses in end brace blocks.

The efforts in brace trusses are determined in the lower belts of the roof trusses from concentrated single forces of wind pressure to the flake of the industrial building, applied at the nodes of the lower belt of the roof trusses - at the level of the sheet hinges on the half-timbered columns at the ends of the building.

The authors consider the geometric patterns of brace trusses along the lower belts of the roof trusses with the efforts in their elements from a unit nodal load of wind pressure to the flake of an industrial building for typical spans of $18,24,30$, and $36 \mathrm{~m}$. It is easy to evaluate the effect of wind pressure on the stress-strain state of the roof trusses in the coupling end blocks, having obtained unit efforts in the elements of brace trusses for any typical spans.

For example, an industrial building with a span of $36 \mathrm{~m}$ and a $6 \mathrm{~m}$ step of bent located in Kramatorsk is considered. For a brace truss with a span of $36 \mathrm{~m}$, the maximum tensile force in the belt from a single horizontal nodal load and the actual one were found.

It should be noted that the function of the belt of the brace truss is performed by the lower belt of the roof truss, the load bearing capacity of which, taking into account the calculated ultimate load, was 3\%. But the effort in the lower belt of the roof trusses in the end brace block increases due to wind pressure at the flank of the building. The combination of two functions in the element of the lower belt leads to a change in the stress state - overwork in the lower belt was $27 \%$.

To the roof trusses of the industrial buildings in end brace blocks, a special approach is needed in assessing the stress-strain state in them.

The proposed methodology makes it possible to assess the stress-strain state of the typical spans roof trusses of industrial buildings in end brace blocks.
\end{abstract}

Keywords: roof truss, sheet hinge, brace block, load, support reaction, fachwerk. 


\title{
ЕКСПЕРИМЕНТАЛЬНЕ ДОСЛІДЖЕННЯ БОЛТОВОГО З'СДНАННЯ ЕЛЕМЕНТІВ 3 КЛЕСНОЇ ДЕРЕВИНИ НА МЕТАЛЕВИХ ПЛАСТИНАХ
}

\author{
Шехоркіна С.С., к.т.н., доцент, \\ Придніпровська державна академія будівництва та архітектури \\ S_VT@ukr.net, ORCID: 0000-0002-4377-3746
}

\begin{abstract}
Анотація. В статті приводяться результати теоретико-експериментальних досліджень роботи болтового з'єднання елементів 3 клеєної деревини на металевих пластинах під дією розтягуючого навантаження паралельно волокнам. 3 урахуванням чинних норм проектування визначено теоретичну несучу здатність з'єднання в залежності від можливої форми руйнування. В результаті випробувань отримано фактичне значення руйнівного навантаження, а також графік залежності деформацій зразка від величини навантаження. Експериментальне значення, відрізняється від теоретичних на $67.5 \%$ та $11.3 \%$, відповідно. Встановлено, що основним параметром, який обумовив несучу здатність з'єднання, $\epsilon$ міцність деревини на вдавлювання під поверхнею болта.
\end{abstract}

Ключові слова: болтове з'єднання, клеєна деревина, металева пластина, несуча здатність, розтяг.

Введення. На сьогоднішній день в багатьох країнах значної популярності набуло застосування будівельних конструкцій з використанням клеєної деревини. 3 використанням нових високотехнологічних виробів зводяться не лише традиційні складські та сільськогосподарські споруди або малоповерхові будівлі, але й багатоповерхові будинки, споруди складної форми та конфігурації. Поряд із стандартними, з'являється велика кількість сучасних з'єднувальних елементів для сполучення деревини з іншими матеріалами (бетоном, цеглою, металом). Поява сучасних видів та технологій виготовлення з'єднань дерев'яних конструкцій обумовлює необхідність проведення відповідних досліджень роботи під навантаженням, оцінки несучої здатності та деформативності.

Аналіз останніх досліджень чи публікацій. Дослідженням роботи з'єднань дерев'яних конструкцій присвячена велика кількість публікацій вітчизняних і закордонних авторів. Серед них слід відзначити роботи В.В. Стоянова, В. В. Фурсова, В. 3. Кліменка, С.С. Гомона та багатьох інших вчених. Автори [1] приводять результати експериментальнотеоретичних досліджень нагельних з'єднань дерев'яних конструкцій вздовж волокон. На основі отриманих даних запропонована методика оцінки несучої здатності розглянутого типу з'єднань. В роботі [2] досліджуються параметри деформативності з'єднання типу “стальдеревина" балок під прямим кутом за допомогою сталевих пластин-підвісів на цвяхах. Виконано порівняльний аналіз отриманих даних відповідно до національних та європейських норм, а також приведені залежності “навантаження-деформація". В роботі [3] описано методику та наведено результати експериментальних досліджень роботи дощатих арок зі з’єднаннями на металозубчатих пластинах. Методика та результати експериментальних досліджень роботи клеєгвинтових з'єднань дощатоклеєних елементів на зсув приведені в [4]. Автори [5] досліджують несучу здатність на згин болтового з'єднання частин збірної шарнірно обпертої балки та приводять графіки залежностей прогину від навантаження. В статті [6] приводяться результати експериментального визначення несучої здатності з'єднань 3 використанням різної кількості болтів при навантаженні паралельно та перпендикулярно волокнам. Порівняння 3 теоретичними даними згідно розрахункових методик показало, що норми дозволяють 3 достатньою точністю прогнозувати міцність болтових з'єднань.

Як показав аналіз досліджень, питання роботи болтових метало-дерев'яних з'єднань в публікаціях вітчизняних вчених висвітлені неповною мірою. 3 огляду на це, метою роботи $\epsilon$ визначення несучої здатності та оцінка деформативності болтового з'єднання елементів 3 
клеєної деревини на сталевих пластинах при роботі на розтяг. Для досягнення поставленої мети були вирішені наступні завдання: визначити теоретичну несучу здатність з'єднання; розробити методику та обладнання для проведення випробувань; отримати діаграму «навантаження-деформація» при послідовному збільшенні розтягуючого зусилля; визначити величину руйнівного навантаження та оцінити характер деформування болтового з'єднання.

Матеріали та методика дослідження. Зразок для дослідження виконаний у вигляді фрагменту реальної конструкції і являє собою дерево-металеву конструкцію, яка складається 3 клеєного дерев'яного бруса довжиною 750 мм, перерізом 120x120 мм та врізаної в масив деревини металевої пластини. Клеєний брус виготовлений з пиломатеріалів деревини сосни. Товщина пластини становить 6 мм, ширина - 80 мм. Спільна робота бруса та пластини забезпечується за рахунок 3 болтів діаметром 12 мм. Відстань між болтами в поздовжньому напрямку становить 140 мм, а від крайнього болта до грані бруса - 90 мм. Загальний вигляд зразка приведений на рис. 1.

a)
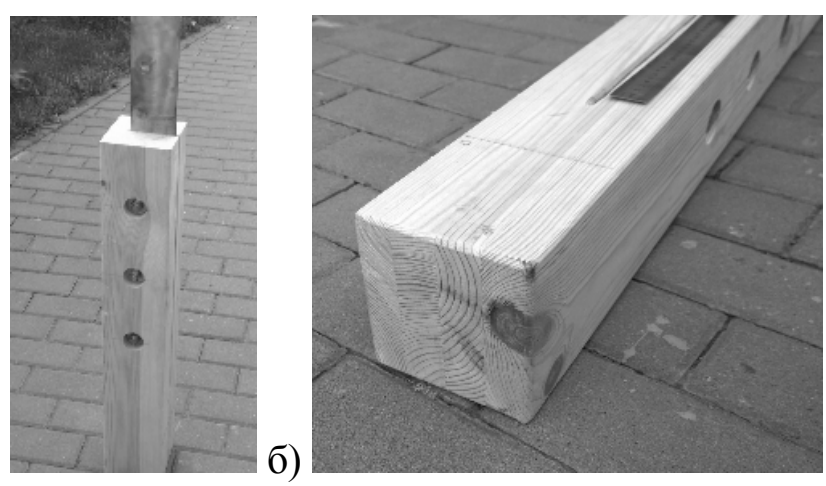

Рис. 1. Загальний вигляд зразка для випробувань (а) та вигляд в поперечному перерізі (б)

Теоретична несуча здатність нагельного з'єднання визначається згідно ДБН В.2.6161:2017. Можливі форми руйнування нагельного з'єднання 3 двома площинами зрізу та сталевою пластиною приведені на рис. 2.

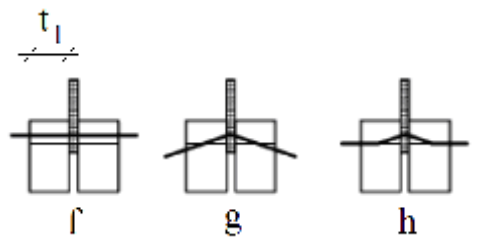

Рис. 2. Форми руйнування нагельного з'єднання з двома площинами зрізу та сталевою пластиною: f, g та h - найменування форм руйнування згідно ДБН В.2.6-161:2017

Для з'єднання 3 двома площинами зрізу та сталевою пластиною будь-якої товщини несуча здатність по кожній площині зрізу на один з'єднувальний елемент (болт) відповідно до форм руйнування може дорівнювати одному з наступних значень:

$$
\begin{gathered}
F_{v, R k}^{f}=f_{h, k} t_{1} d, \\
F_{v, R k}^{g}=f_{h, k} t_{1} d\left[\sqrt{2+\frac{4 M_{y, R k}}{f_{h, k} d t_{1}^{2}}}-1\right], \\
F_{v, R k}^{h}=1.15 \sqrt{2 M_{y, R k} f_{h, k} d},
\end{gathered}
$$

де $t_{1}$ - товщина елементу 3 деревини; $d$ - діаметр болта; $f_{h, k}$ - характеристична міцність вдавлення з'єднувального елемента в масив деревини; $M_{y, R k}$ - характеристичний момент текучості.

Характеристичний момент текучості болта визначається за формулою:

$$
M_{y, R k}=0.3 f_{u, k} d^{2,6},
$$


де $f_{u, k}$ - характеристична міцність при розтягу болта.

Значення характеристичної міцності вдавлення з’єднувального елемента в масив деревини прийнято $f_{h, k}=50 M П а$ на основі випробувань, проведених в роботі [7]. Характеристична міцність при розтягу болта $f_{u, k}=500 \mathrm{MПа.}$

Таблиця 1 - Теоретичні значення характеристик 3'єднання

\begin{tabular}{|c|c|c|c|c|}
\hline $\begin{array}{c}\text { Характеристична } \\
\text { міцність } \\
\text { вдавлення }\end{array}$ & $\begin{array}{c}\text { Характеристичний } \\
\text { момент текучості } \\
\text { болта }\end{array}$ & $\begin{array}{c}\text { Tеоретична несуча здатність 3'єднання на один } \\
\text { 3'єднувальний елемент }\end{array}$ \\
\hline$f_{h, k}, \mathrm{MПа}$ & $M_{y, R k}, \mathrm{\kappa H} \cdot \mathrm{Mм}$ & $F_{v, R k}^{f}, \mathrm{\kappa H}$ & $F_{v, R k}^{g}, \mathrm{\kappa H}$ & $F_{v, R k}^{h}, \mathrm{\kappa H}$ \\
\hline 50 & 95.9 & 33.6 & 16.3 & 12.3 \\
\hline
\end{tabular}

Враховуючи те, що в з'єднанні застосовується три болта очікуване руйнівне навантаження становитиме в межах від $F_{\min }=36.9$ кН до $F_{\max }=100.8$ кН.

Для виконання завдань експерименту була розроблена установка, що забезпечує навантаження зразка розтягуючим зусиллям до 150 кН. На рис. 3 показаний ескіз установки в зборі зі зразком.

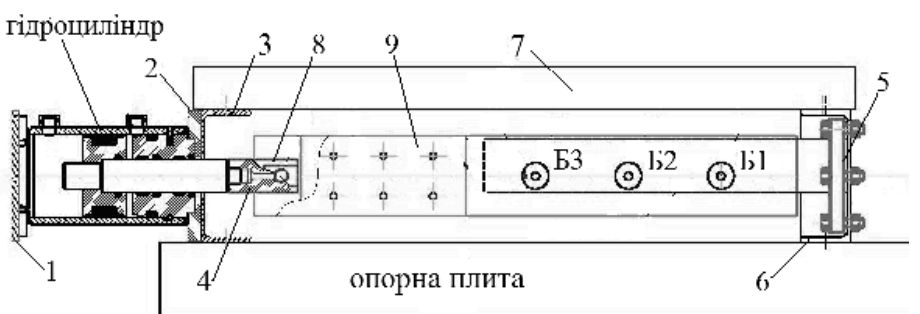

Рис. 3. Ескіз установки для дослідження зразка на розтяг (пояснення до позначень приведені у тексті)

Оскільки в експерименті планувалося використання високоточних датчиків переміщення, то установка розроблялася для монтажу на жорсткій опорній плиті. Установка містить гідроциліндр закріплений на пластині (поз. 1), що забезпечує його фіксацію на опорній пластині (поз. 2) швелера (поз. 3). Шток гідроциліндра проходить через отвір в швелері (поз. 3) і за допомогою головки (поз. 4) з'єднується з накладками (поз. 9) за допомогою штифта (поз. 8). Накладки розташовані по обидва боки дерев'яного бруса, виконані зі сталевого листа товщиною 12 мм і стягнуті 6 болтами М10. Протилежний кінець бруса фіксується за допомогою сталевої з'єднувальної пластини до швелера (поз. 6) i кріпиться через накладки (поз. 5) за допомогою 6-ти болтів M12. Швелери (поз. 3 та 6) в нижній частині кріпляться до опорної плиті за допомогою високоміцного нарізного кріплення. Зверху швелери поз. 3 і 6 з'єднані розпірними кутниками (поз. 7). На рис. 4 показана установка в зборі, після монтажу на опорній плиті.

Для реєстрації переміщень в процесі впливу розтягуючого зусилля застосовувався датчик Honeywell Sensing and Control LTW05N05KF5C. Для цього була обрана точка в районі головки болта Б3 (рис. 3). При цьому чутливий елемент датчика не контактував 3 кріпильними елементами, а упирався в стінку фрезерованого отвору на відстані 9 мм від зовнішньої поверхні бруса. На рис. 5 показано розміщення датчика.

В процесі виконання експерименту в гідроциліндр подавалася гідрорідина 3 темпом наростання тиску $0.1 \mathrm{MПа/хв.} \mathrm{При} \mathrm{цьому} \mathrm{йшла} \mathrm{безперервна} \mathrm{реєстрація} \mathrm{даних,} \mathrm{що} \mathrm{надходять} 3$ датчиків тиску і переміщення. Реєстрація зусилля, що діє на зразок, виконувалася за допомогою контролю тиску в гідросистемі. 3 цією метою використовувався датчик тиску МД-150ТС. Величина зусилля визначалася шляхом множення значення тиску в гідроциліндрі на ефективну площу його поршня, яка у режимі розтягуючого навантаження складає $0.0103 \mathrm{~m}^{2}$. 


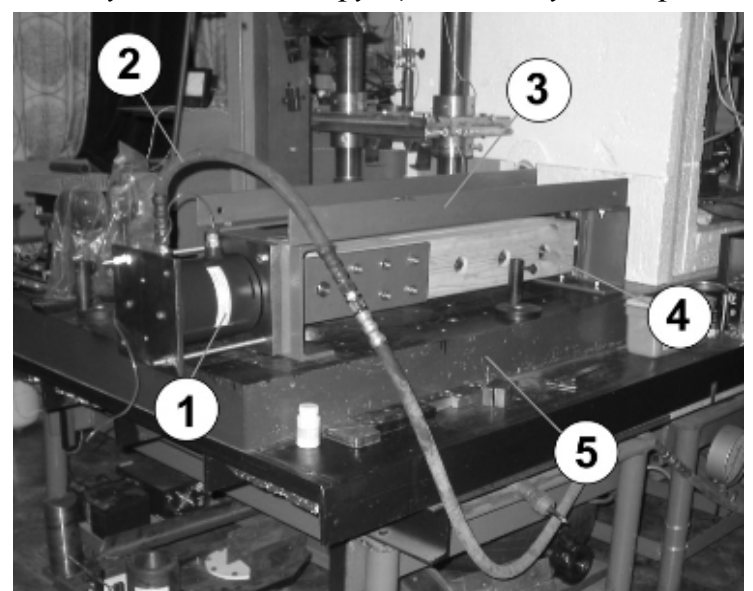

Рис. 4. Випробувальне оснащення в змонтованому вигляді: 1 -гідроциліндр; 2 шланг гідросистеми; 3 - випробувальне оснащення; 4 - зразок; 5 - опорна плита

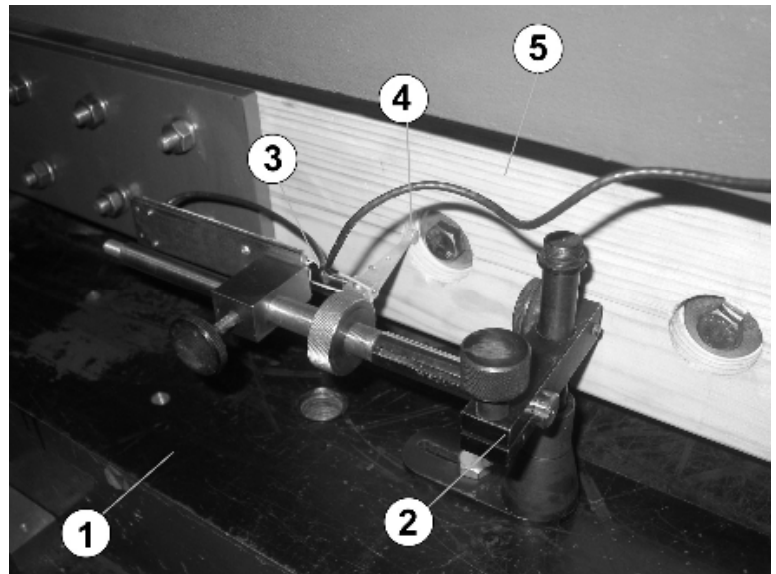

Рис. 5. Датчик осьового переміщення: 1 - опорна плита, 2 - кріплення датчика; 3 датчик осьового переміщення, 4 - точка вимірювання переміщення, 5 - зразок

Дискретність опитування датчиків становила 1 с. Сигнали датчиків тиску i переміщення надходили на блок узгодження, з'єднаний 3 аналогово-цифровим перетворювачем, звідки після перетворення в цифрову форму передавалися в комп'ютер i записувалися на його жорсткий диск. Подальша обробка інформації проводилася програмними засобами, що забезпечують побудову таблиць і графіків за значеннями реєстрованих параметрів.

Результати досліджень. До досягнення тиску 7.5-8.0 МПа процес деформування проходив досить рівномірно, без будь-яких особливостей. Процес навантаження зразка супроводжувався випадковим потріскуванням, але візуально поява будь-яких ушкоджень не спостерігалася. При подальшому збільшенні навантаження податливість системи істотно зросла. Зростання тиску супроводжувалося безперервним тріском волокон деревини, що було обумовлено їх розривом. Руйнування зразка відбулося при навантаженні 113.7 кН. Отримане в результаті випробувань значення руйнівного навантаження та його порівняння 3 теоретичними значеннями приведено в табл. 2.

Таблиця 2 - Результати випробування болтового з'єднання елементів 3 клеєної деревини на сталевих пластинах

\begin{tabular}{|c|c|c|c|c|}
\hline $\begin{array}{c}\text { Експериментальне } \\
\text { значення, кН }\end{array}$ & $\begin{array}{c}\text { Мінімальне теоретичне } \\
\text { значення, кН }\end{array}$ & $\begin{array}{c}\% \\
\text { різниці }\end{array}$ & $\begin{array}{c}\text { Максимальне теоретичне } \\
\text { значення, кН }\end{array}$ & $\begin{array}{c}\% \\
\text { різниці }\end{array}$ \\
\hline 113.7 & 36.9 & 67.5 & 100.8 & 11.3 \\
\hline
\end{tabular}

Як видно 3 табл. 2 мінімальне теоретичне значення несучої здатності болтового з'єднання елементів 3 клеєної деревини на сталевих пластинах на 67.5 \% відрізняється від експериментального, тоді як максимальне значення - на 11.3 \%. Таким чином, основним параметром, що обумовлює несучу здатність 3'єднання є міцність деревини на вдавлювання під поверхнею болта.

В результаті випробувань було отримано графік залежності «навантаженняпереміщення», який приведено на рис. 6. Як видно з графіка, процес деформування зразка починається 3 локального обминання при значенні навантаження до $20 \mathrm{kH}$, після чого спостерігається близька до лінійної ділянка. Поява нелінійних деформацій відповідає навантаженню близько 80 кН і зумовлена згинанням болтів.

Після завершення експерименту було проведено розбирання зразка і дефектація складових елементів (рис. 7). За результатами аналізу згину болтів можна припустити, що в конструкції достатньо рівномірно відбувається перерозподіл зусиль. 


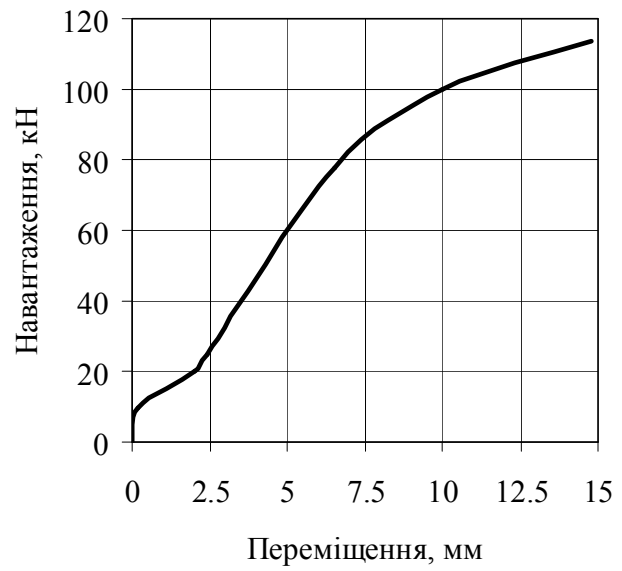

Рис. 6. Графік залежності деформацій зразка від величини розтягуючого навантаження

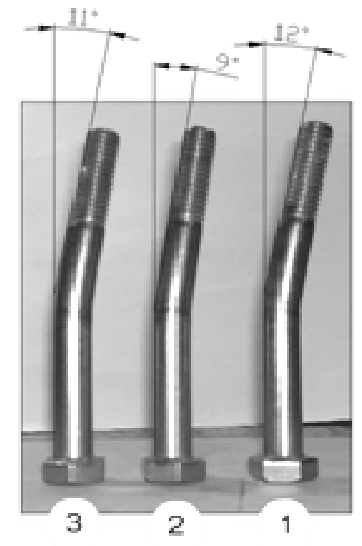

Рис. 7. Зміна форми болтів в результаті згину під дією навантаження

Висновки. 3 метою визначення несучої здатності та оцінки деформативності проведені випробування на розтяг паралельно волокнам болтового 3'єднання елементів 3 клеєної деревини на металевих пластинах. В результаті експерименту отримано значення руйнівного навантаження, яке склало 113.7 кН, а також графік залежності деформацій зразка від величини розтягуючого навантаження. Робота зразка при значенні навантаження до 80 кН характеризується близькою до лінійної залежністю, після чого виникають нелінійні деформації, зумовлені згинанням болтів. Аналіз форми згину болтів дозволяє припустити, що в конструкції перерозподіл зусиль відбувається рівномірно.

3 урахуванням чинних норм визначені теоретичні значення несучої здатності з'єднання відповідно до можливих форм руйнування, які склали $F_{\min }=36.9$ кН та $F_{\max }=100.8$ кН. Експериментальне значення, відрізняється від теоретичних, на $67.5 \%$ та $11.3 \%$, відповідно. Згідно отриманих даних, основним параметром, що обумовлює несучу здатність з'єднання, $\epsilon$ міцність деревини на вдавлювання під поверхнею болта.

\section{Література}

1. Гомон С. С., Алексієвець В. І. Робота та розрахунок сталевих нагельних з’єднань дерев'яних конструкцій за повторних навантажень: монографія. Рівне, 2013. 111 с. [Електронний pecypc] http://ep3.nuwm.edu.ua/1725/1/732819\%20zah.pdf (дата звернення: 08.05.2020).

2. Була С. Деформативність вузлів дерев'яних конструкцій на 3'єднаннях типу “стальдеревина". Вісник національного університету "Львівська політехніка". Серія: Теорія $i$ практика будівництва. Львів : Видавництво Львівської політехніки. 2017. № 877. С. 18-24. [Електронний ресурс] http://ena.lp.edu.ua:8080/handle/ntb/44217 (дата звернення: 08.05.2020).

3. Демчина Б. Г., Шидловський Я. М. Дослідження міцності та деформативності дощатих арок на металозубчатих пластинах. Містобудування та територіальне планування. 2016. Вип. 61. С. 164-172. [Електронний ресурс] http://nbuv.gov.ua/UJRN/MTP_2016_61_24 (дата звернення: 08.05.2020).

4. Кислюк Д. Я., Чапюк О. С. Дослідження роботи клеєметалевих з’єднань елементів дерев'яних конструкцій. Сучасні технологї та методи розрахунків у будівництві. 2018. Вип. 9. C. 63-69. [Електронний ресурс] http://nbuv.gov.ua/UJRN/stmrb_2018_9_11 (дата звернення: 08.05.2020).

5. Lesmana C., Suhendi S. Experimental investigation of connection performance for prefabricated timber beam. IOP Conf. Series: Earth and Environmental Science. 2017. Vol. 69. [Електронний pecypc] https://doi.org/10.1088/1755-1315/69/1/012113 (дата звернення: 08.05.2020). 
6. Gattesco N., Toffolo I. Experimental study on multiple-bolt steel-to-timber tension joints. Materials and Structures, 2004. Vol. 37(2), P. 129-138. [Електронний ресурс] https://doi.org/10.1007/BF02486609 (дата звернення: 08.05.2020).

7. Шехоркіна С. Є., Кесарійский А. Г. Дослідження особливостей деформування та міцності деревини на вдавлення із застосуванням методу голографічної інтерферометрії. Вісник Придніпровської державної академії будівництва та архітектури. 2019. № 4. С. 93-99. [Електронний pecypc] http://visnyk.pgasa.dp.ua/article/view/180667/180683 (дата звернення: 08.05.2020).

\section{References}

[1] S. S. Homon, V. I. Aleksiievets, "Robota ta rozrakhunok stalevykh nahelnykh ziednan derevianykh konstruktsii za povtornykh navantazhen" : monohrafiia. Rivne, 2013. 111 pp. Available: http://ep3.nuwm.edu.ua/1725/1/732819\%20zah.pdf. Accessed on: May 08, 2020.

[2] S. Bula, "Deformatyvnist vuzliv derevianykh konstruktsii na ziednanniakh typu "stalderevyna", Visnyk natsionalnoho universytetu "Lvivska politekhnika". Seriia: Teoriia $i$ praktyka budivnytstva. Lviv : Vydavnytstvo Lvivskoi politekhniky, 2017, № 877, pp. 18-24. Available: http://ena.lp.edu.ua:8080/handle/ntb/44217. Accessed on: May 08, 2020.

[3] B. H. Demchyna, Ya. M. Shydlovskyi, "Doslidzhennia mitsnosti ta deformatyvnosti doshchatykh arok na metalozubchatykh plastynakh", Mistobuduvannia ta terytorialne planuvannia, 2016, Vol. 61, pp. 164-172. Available: http://nbuv.gov.ua/UJRN/MTP_2016_61_24. Accessed on: May 08, 2020.

[4] D. Ya. Kysliuk, O. S. Chapiuk, "Doslidzhennia roboty kleiemetalevykh ziednan elementiv derevianykh konstruktsii", Suchasni tekhnolohii ta metody rozrakhunkiv u budivnytstvi, 2016, Vol. 61, pp. 164-172. Available: http://nbuv.gov.ua/UJRN/MTP_2016_61_24. Accessed on: May 08, 2020.

[5] C. Lesmana, S. Suhendi, «Experimental investigation of connection performance for prefabricated timber beam", IOP Conf. Series: Earth and Environmental Science. 2017. Vol. 69. Available: https://doi.org/10.1088/1755-1315/69/1/012113. Accessed on: May 08, 2020.

[6] N. Gattesco, I. Toffolo, "Experimental study on multiple-bolt steel-to-timber tension joints", Materials and Structures, 2004, Vol. 37(2), P. 129-138. Available: https://doi.org/10.1088/1755-1315/69/1/012113. Accessed on: May 08, 2020.

[7] S. Ye. Shekhorkina, A. H. Kesariiskyi, "Doslidzhennia osoblyvostei deformuvannia ta mitsnosti derevyny na vdavlennia iz zastosuvanniam metodu holohrafichnoi interferometrii", Visnyk Prydniprovskoi derzhavnoi akademii budivnytstva ta arkhitektury, 2019. № 4. pp. 9399. Available: http://visnyk.pgasa.dp.ua/article/view/180667/180683. Accessed on: May 08, 2020.

\section{ЭКСПЕРИМЕНТАЛЬНОЕ ИССЛЕДОВАНИЕ БОЛТОВОГО СОЕДИНЕНИЯ ЭЛЕМЕНТОВ ИЗ КЛЕЕНОЙ ДРЕВЕСИНЫ НА СТАЛЬНЫХ ПЛАСТИНАХ}

Шехоркина С.Е., к.т.н., доцент, «Приднепровская государственная академия строительства и архитектурыл» S_VT@ukr.net, ORCID: 0000-0002-4377-3746

Аннотация. В настоящее время в мире большую популярность приобрело применение деревянных конструкций. Появление современных видов и технологий изготовления соединений элементов деревянных конструкций обусловливает необходимость проведения соответствующих исследований работы под нагрузкой, теоретической и экспериментальной оценки несущей способности и деформативности.

В статье приводятся результаты теоретико-экспериментальных исследований работы болтового соединения элементов из клееной древесины на металлических пластинах под действием растягивающей нагрузки параллельно волокнам. 
Для исследования был принят образец, состоящий из клееного деревянного бруса длиной 750 мм сечением 120x120 мм и врезанной в массив древесины стальной соединительной пластины. Совместная работа бруса и пластины обеспечивается за счет трех болтов диаметром 12 мм. Клееный брус изготовлен из пиломатериалов древесины сосны.

Разработана методика проведения эксперимента. В результате испытаний получено фактическое значение разрушающей нагрузки, которое составило 113.7 кН, а также график зависимости деформаций образца от величины растягивающей нагрузки. Работа образца при значении нагрузки до 80 кН характеризуется близкой к линейной зависимостью. При больших значениях нагрузки проявляются нелинейные деформации, обусловленные изгибом болтов. Анализ формы изгиба болтов позволяет предположить, что в соединении перераспределение усилий происходит равномерно.

С учетом действующих норм проектирования определены теоретическую несущую способность соединения согласно возможных форм разрушения. Экспериментальное значение, отличается от теоретических на $67.5 \%$ и $11.3 \%$, соответственно. Установлено, что основным параметром, который обусловил несущую способность соединения, является прочность древесины на вдавливания под поверхностью болта.

Ключевые слова: болтовое соединение, клееная древесина, металлическая пластина, несущая способность, растяжение.

\title{
EXPERIMENTAL INVESTIGATION OF BOLTED TIMBER CONNECTIONS WITH STEEL PLATES
}

\author{
Shekhorkina S.Yev., Ph.D., Associate Professor, \\ "Prydniprovska State Academy of Civil Engineering and Architecture» \\ S_VT@ukr.net, ORCID: 0000-0002-4377-3746
}

\begin{abstract}
Currently, the use of timber building structures has gained great popularity in the world. The appearance of modern types and technologies for the manufacturing of joints of timber structures elements makes it necessary to conduct corresponding studies of its behaviour under load, as well as theoretical and experimental assessment of load-bearing capacity and deformability.

The article presents the results of theoretical and experimental studies of the performance of the bolted connection of glued timber elements with metal plates under the action of a tensile load parallel to the fibers.

A sample consisting of a glued timber beam $750 \mathrm{~mm}$ long with cross-section section dimensions of 120x120 mm and a connecting steel plate embedded in a solid wood was adopted for the study. The joint work of the beam and the plate is ensured by three bolts with a diameter of $12 \mathrm{~mm}$. Glued laminated timber is made of pine wood lumber.

The technique for the experiment was developed. As a result of the tests, the actual value of the failure load equal to $113.7 \mathrm{kN}$ was obtained, as well as a diagram of the dependence of the deformation of the sample on the magnitude of the tensile load. The behaviour of the sample under a load up to $80 \mathrm{kN}$ is characterized by a close to linear dependence. At larger values of the load, nonlinear deformations occur due to the bending of the bolts. An analysis of the shape of the bending of the bolts allows suggesting the uniform redistribution of the inner forces of the connection.

Taking into account the current design standards, the theoretical bearing capacity of the joint was determined according to the possible forms of failure. The experimental value differs from theoretical by $67.5 \%$ and $11.3 \%$, respectively. It is established that the main parameter that has determined the bearing capacity of the connection is the embedment strength of the wood under the surface of the bolt.
\end{abstract} tension.

Keywords: bolted connection, glued laminated timber, metal plate, load-bearing capasity, 


\title{
ОПЫТ КОНСТРУИРОВАНИЯ ФЕРМ ИЗ ГНУТОСВАРНЫХ ПРОФИЛЕЙ В СООТВЕТСВИИ С ТРЕБОВАНИЯМИ ЕN 1993-1
}

\author{
Шурин А.Б., к.т.н., доцент, \\ shuryn@mail.ru, ORCID: 0000-0003-1396-3503 \\ Мухин А.В., к.т.н., доцент, \\ УО «Брестский государственный технический университет» \\ myhinanatoli@tut.by
}

Аннотация. В настоящее время в Республике Беларусь, в зависимости от задания на проектирование, расчёт стальных конструкций допускается выполнять как в соответствии с требованиями СНиП II-23, так и по ТКП ЕN 1993-1. В статье приведено сопоставление конструктивных решений ферм из прямоугольных труб с бесфасоночными узлами, запроектированных по ТКП ЕN 1993 и СНиП II-23, и применёных на различных объектах Республики Беларусь. Выполнен анализ наиболее часто встречающихся ошибок при их проектировании.

Представлено конструктивное решение разработанного и реализованного авторами конструктивного решения по усилению монолитного ребристого чердачного перекрытия с использованием пространственных трёхгранных ферм из гнутосварных профилей, запроектированных с использованием ТКП ЕN 1993-1.

Ключевые слова: фермы, узлы, гнутосварные профили, Еврокод, несущая способность, продавливание, прочность, потеря местной устойчивости.

Введение. История применения стальных ферм составляет несколько сотен лет. Практика строительства показала, что наиболее экономичны стальные сварные фермы из круглых, затем из прямоугольных труб, получаемых методом холодного деформирования на специальных поточных линиях. Подобная линия фирмы «Маннесман» существует в Республике Беларусь в г. Молодечно, где с 1978 года осуществляется как выпуск профилей стальных замкнутых гнутых сварных квадратных и прямоугольных (ГОСТ 30245), так и ферм из соответствующих профилей.

Целью данной работы является анализ и сопоставление основных положений по расчету узлов ферм из прямоугольных труб с бесфасоночными узлами, выполненных по СНиП II-23 [1, 2] и ТКП ЕN 1993-1[3].

Результаты анализа. Общеизвестно, что в стержневых конструкциях из труб при бесфасоночных узловых соединениях расход металла, определяется предельными состояниями узловых соединений. Следует отметить, что методы оценки предельных состояний узловых соединений в нормативных базах являются эмпирическими, и основаны на достаточно ограниченных базах экспериментальных исследований [4]. Далеко не для всех видов предельных состояний узловых соединений из прямоугольных труб предложены методики расчёта.

Расчет и конструирование узлов из прямоугольных труб в соответствии с требованиями СНиП II-23, приведенный в [2], следует производить на:

- продавливание (вырывание) участка стенки пояса, контактирующей с элементом решетки;

- несущую способность участка боковой стенки пояса (параллельной плоскости узла) в месте примыкания сжатого элемента решетки;

- несушую способность элемента решетки в зоне примыкания к поясу;

- прочность сварных швов прикрепления элемента решетки к поясу [4].

В Республике Беларусь с 01 января 2010 года введены европейские нормы проектирования. Применение при проектировании ферм из гнутосварных профилей ТКП ЕN 1993-1-8 [3] значительно расширяет их область применения. Расчет и конструирование таких узлов по методике, изложенной в ТКП ЕN 1993-1-8 производится на: 
- отказ лицевой поверхности пояса (отказ вследствие пластического разрушения лицевой поверхности пояса) или пластификация пояса (отказ вследствие пластического разрушения поперечного сечения пояса);

- отказ боковой поверхности пояса (или отказ стенки пояса) из-за раздавливания, пластификации или неустойчивого состояния (выгиб или потеря устойчивости боковой поверхности пояса из замкнутого профиля или стенки пояса) в месте примыкания сжатого стержня решетки;

- сдвиг (срез) сечения пояса;

- вырывание поверхности пояса (отказ из-за возникновения трещины, инициирующей отрыв стержня решетки от пояса);

- потеря местной устойчивости стержня решетки [4].

Таким образом, ТКП ЕN 1993-1-8 предоставляет больше вариантов по конструированию узлов из прямоугольных труб: больший диапазон толщин труб и углов наклона решетки к поясу, возможность расчета и конструирования пространственных узлов. В [4] содержится больше вариантов разрушения узлов из прямоугольных труб, однако не по всем схемам разрушения приведены соответствующие формулы расчета. В частности, в ТКП ЕN 1993-1-8 расчет прочности сварных швов, прикрепляющих стержни решетки к поясам не приведен, вследствие принятой гипотезы равнопрочности их основному металлу. При этом игнорируется проблема использования разных сталей для стержневых элементов и деталей, соединяющихся в узлах. Также ТКП ЕN 1993-1-8 содержит более жесткие требования к профилям, их химическому составу и раскислению стали $[5,6]$.

Сравнительный анализ области применения ферм из гнутосварных профилей приведен в таблице 1.

Таблица 1 - Область применения стержней ферм из прямоугольных труб по СНиП II-23 и ТКП ЕН 1993-1-8 [5]

\begin{tabular}{|c|c|c|}
\hline Нормируемый параметр & СНиП II-23 & ТКП ЕN 1993-1-8 \\
\hline $\begin{array}{c}\text { Минимальная толщина стенки } \\
\text { стержней фермы, мм }\end{array}$ & 3 & 2,5 \\
\hline $\begin{array}{c}\text { Максимальная толщина стенки } \\
\text { стержней фермы, мм }\end{array}$ & $\begin{array}{l}12-\text { по ГОСТ 30243-2003 } \\
22 \text { - по ГОСТ 30243-2012 }\end{array}$ & $\begin{array}{l}25 \text { (ограничивается } \\
\text { EN 10219-2:1997) }\end{array}$ \\
\hline $\begin{array}{c}\text { Отношение ширины раскоса } \\
\text { к ширине пояса }\end{array}$ & $0,6-0,9$ & $0,25-1,0$ \\
\hline $\begin{array}{c}\text { Минимальный угол } \\
\text { наклона раскосов, град }\end{array}$ & $38^{\circ}$ & $30^{\circ}$ \\
\hline Применяемый класс стали & $\mathrm{C} 245 \ldots \mathrm{C} 460$ & Стали с $f_{y} \leq 460 \mathrm{MПа}$ \\
\hline Требования к профилям & Нет & $\begin{array}{l}\text { Должны соответствовать } \\
\text { EN } 10210 \text { или EN } 10219\end{array}$ \\
\hline $\begin{array}{c}\text { Требования к химическому } \\
\text { составу }\end{array}$ & Нет & $\begin{array}{c}C=(0,09-0,15) \% \\
P \leq 0,04 \% ; S \leq 0,05 \%\end{array}$ \\
\hline Требования к раскислению стали & Нет & $A l \geq 0,02 \%$ \\
\hline Дополнительные требования & Нет & Класс сечения 1 или 2 \\
\hline $\begin{array}{c}\text { Возможность расчета и } \\
\text { конструирования } \\
\text { пространственных узлов } \\
\end{array}$ & Нет & $\begin{array}{c}\text { Да } \\
\text { (узлы типа КК, ТТ и XX) }\end{array}$ \\
\hline
\end{tabular}

Ошибки при проектировании ферм из прямоугольных труб. Расчёт и конструирование узлов ферм из прямоугольных труб в соответствии с требованиями, приведенными в [2] производится при углах наклона решётки к поясу от 38 градусов. В соответствии с требованиями Еврокодов, приведенными в ТКП ЕN 1993-1-8 [3] от 30 градусов (таблица 1). 
Анализ применения конструктивных решений ферм из прямоугольных труб для сооружений в Республике Беларусь показал, что их проектирование зачастую ведется с отклонениями от требований, приведенных не только в EN 1993-1-8 [3], но и СНиП II-23 [1, 2]. Часть отклонений связаны с выходом за пределы углов наклона стержней решетки в узлах при их проектировании по соответствующим нормам (рис. 1, 2).

a)

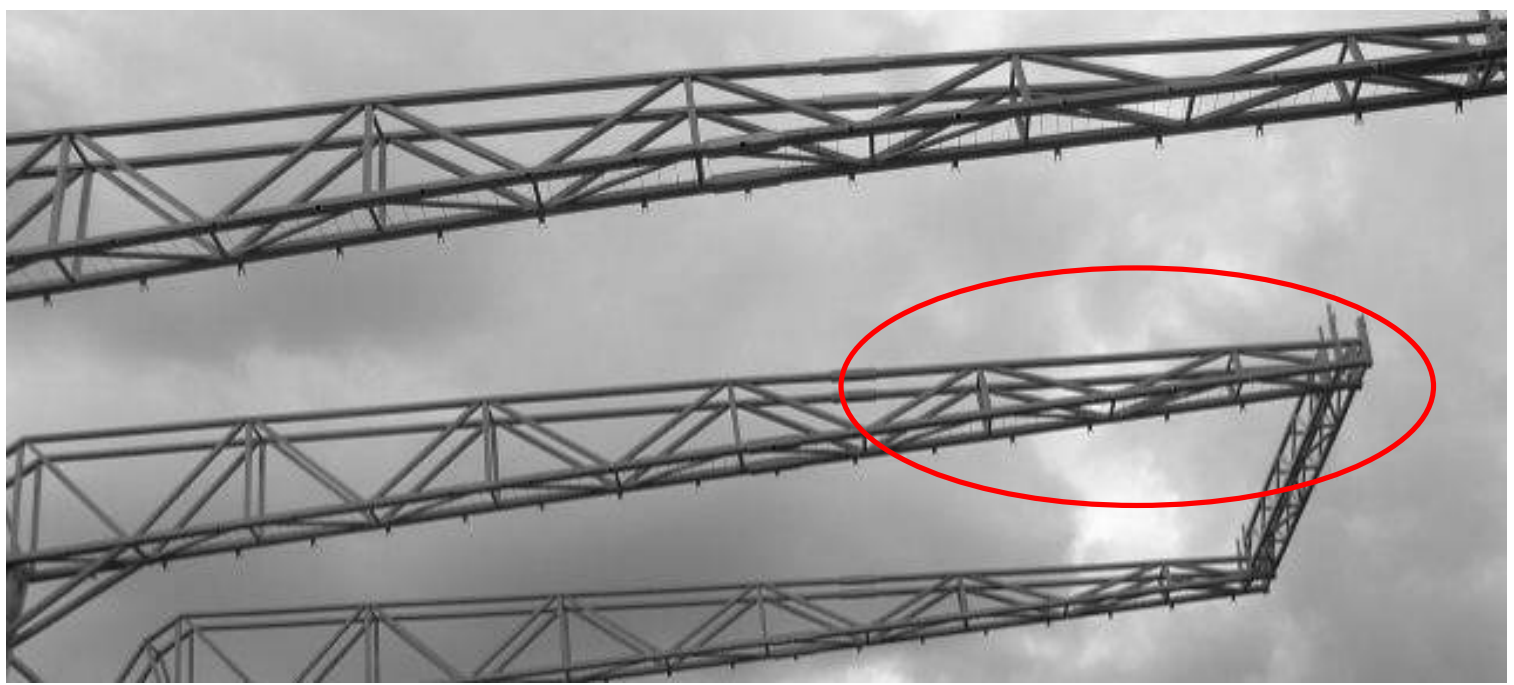

б)

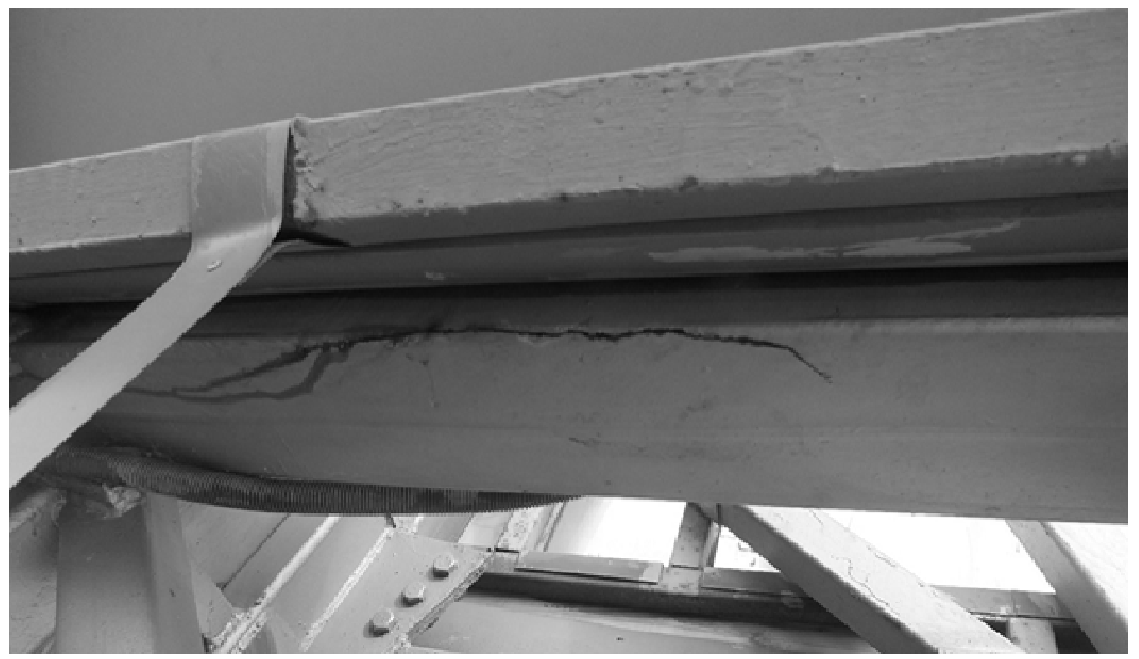

Рис. 1. Ошибки при конструировании ферм из ГСП:

$\mathrm{a}-$ несоответствие угла наклона стержней решетки в узлах требованиям $[2,3]$;

б - трещины в поясах ферм из-за некачественных сварных швов

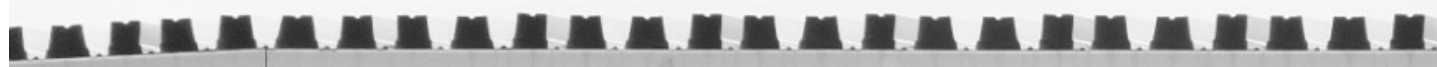

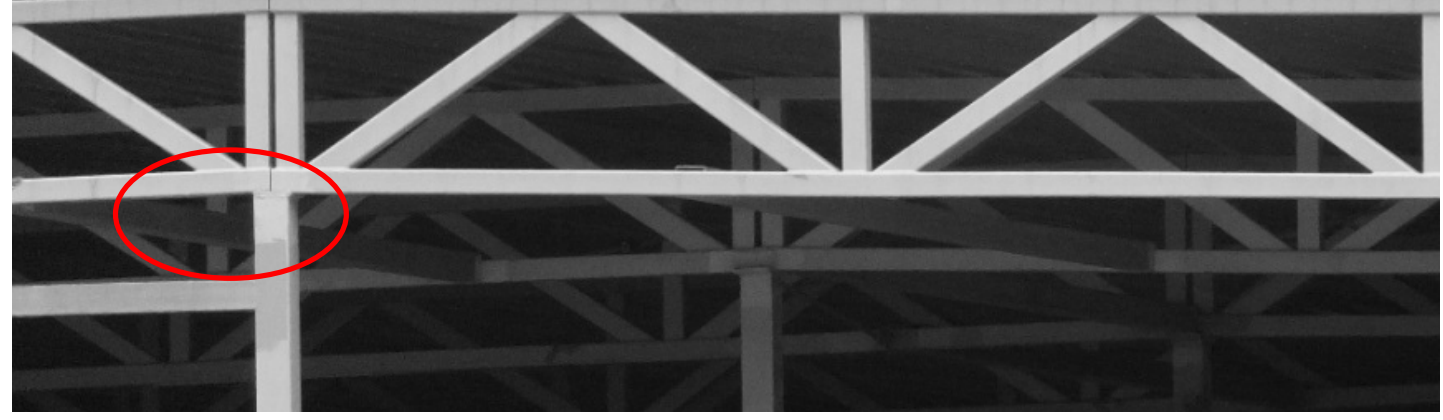

Рис. 2. Применение нетипового опорного узла фермы 
Достаточно ярким примером непонимания проектировщиками методологии расчёта и проектирования узлов, основанной строго на экспериментальных исследованиях являются рамные конструкции пилонов, поддерживающих навес стадиона в г. Бресте (Республика Беларусь). В плоских фермах консолей пилонов навеса над стадионом угол наклона раскосов к поясам составляет менее 30 градусов (рис. 1a). Обрушения не происходит только ввиду относительно небольших усилий в элементах решётки. Наблюдается разрушение элементов ферм вследствие замерзания попавшей воды из-за некачественных сварных швов в пятках раскосов, причём чрезвычайно сложно обнаружить дефекты такого характера (рис. 1б).

Вторая типичная ошибка - применение типов узловых соединений, для которых не исследованы виды отказа, поэтому применение формул из нормативных документов [2, 3] при их конструировании недопустимо (рис. 2) [7].

Треугольные фермы из прямоугольных труб. Сечение гнутосварного профиля является идеальным для трёхгранной призматической стержневой конструкции с точки зрения простоты организации узлового пространственного соединения. В соответствии с таблицей 1 , ТКП ЕN 1993-1-8 [3] предоставляет возможность расчета и конструирования пространственных бесфасоночных узлов: типа КК, ТТ и XX. Применение треугольных ферм с такими узлами в каркасах зданий позволяет уменьшить затраты на устройство в конструкциях покрытия связей или полностью исключить поперечные связи по покрытию.

Авторами разработано и реализовано конструктивное решение по усилению монолитного ребристого чердачного перекрытия здания прессового цеха СОАО «Беловежские сыры» в г. Высокое Брестской области с использованием пространственных трёхгранных ферм из гнутосварных профилей. Основная идея усиления чердачного перекрытия, находящегося в аварийной ситуации, заключалась в его подвешивании к самостоятельным несущим конструкциям в виде трёхгранных ферм, опирающихся на вертикальные несущие элементы. Несущие конструкции усиления (трехгранные фермы) вынесены в чердачное пространство и размещены между стропильными ногами и стойками продольных деревянных рам стропильной системы (рис. 3).

Пролет ферм по осям колонн 13,1 м. Высота ферм по осям поясов 1400 мм, полная высота - 1564 мм (рис. 3). Пояса выполнены из труб стальных гнутых замкнутых сварных квадратных по ГОСТ 30245-2012: верхний пояс - гн.140х6 / С345, нижние пояса - гн.140х4 / C255. Раскосы - гн. 100x3 / C255. Угол наклона в плоскости грани решетки не менее $44^{\circ}$, что удовлетворяет требованиям пункта 7.1.2(3) [3]. Верхние узлы запроектированы по типу КК и ТТ-образных (см. рис.7.1 [3]).

Расчет узлов фермы из трёхгранных профилей удовлетворяет требованиям п. 7.5.3 [3]. Опорная реакция с трёхгранных ферм передаётся на стальные стойки (гн.140x4) с консольными траверсами, а нагрузка от стоек - на отдельные фундаменты, устроенные вплотную с существующими ленточными фундаментами стен. Фундаменты по стальные стойки выполнены столбчатыми на естественном основании.

Включение в работу всей конструкции усиления осуществлялось путём натяжения подвесок (d20 ГОСТ 2590) при помощи гаек М20, на которых подвешена неразрезная главная балка монолитного ребристого чердачного перекрытия. В результате наблюдения за монолитным перекрытием силовых дефектов не обнаружено, прогибы не превышают значений, установленных в действующих ТНПА [5].

\section{Выводы:}

1. В результате анализа конструктивных решений ферм из прямоугольных труб в Республике Беларусь установлено, что их проектирование зачастую ведется с отклонениями от требований, приведенных не только в ТКП ЕN 1993-1-8 [3], но и СНиП II-23-81[1, 2].

2. Расчёт и конструирование узлов ферм из прямоугольных труб при углах наклона решётки к поясу менее 38 градусов по СНиП II-23-81*, и менее 30 градусов по ТКП ЕN 1993-18 не производится. Данная тема является актуальной с точки зрения исследования предельных состояний и технологии сварки и нуждается в дальнейшей разработке, что позволит расширить область применения пространственных и плоских ферменных конструкций. 
a)

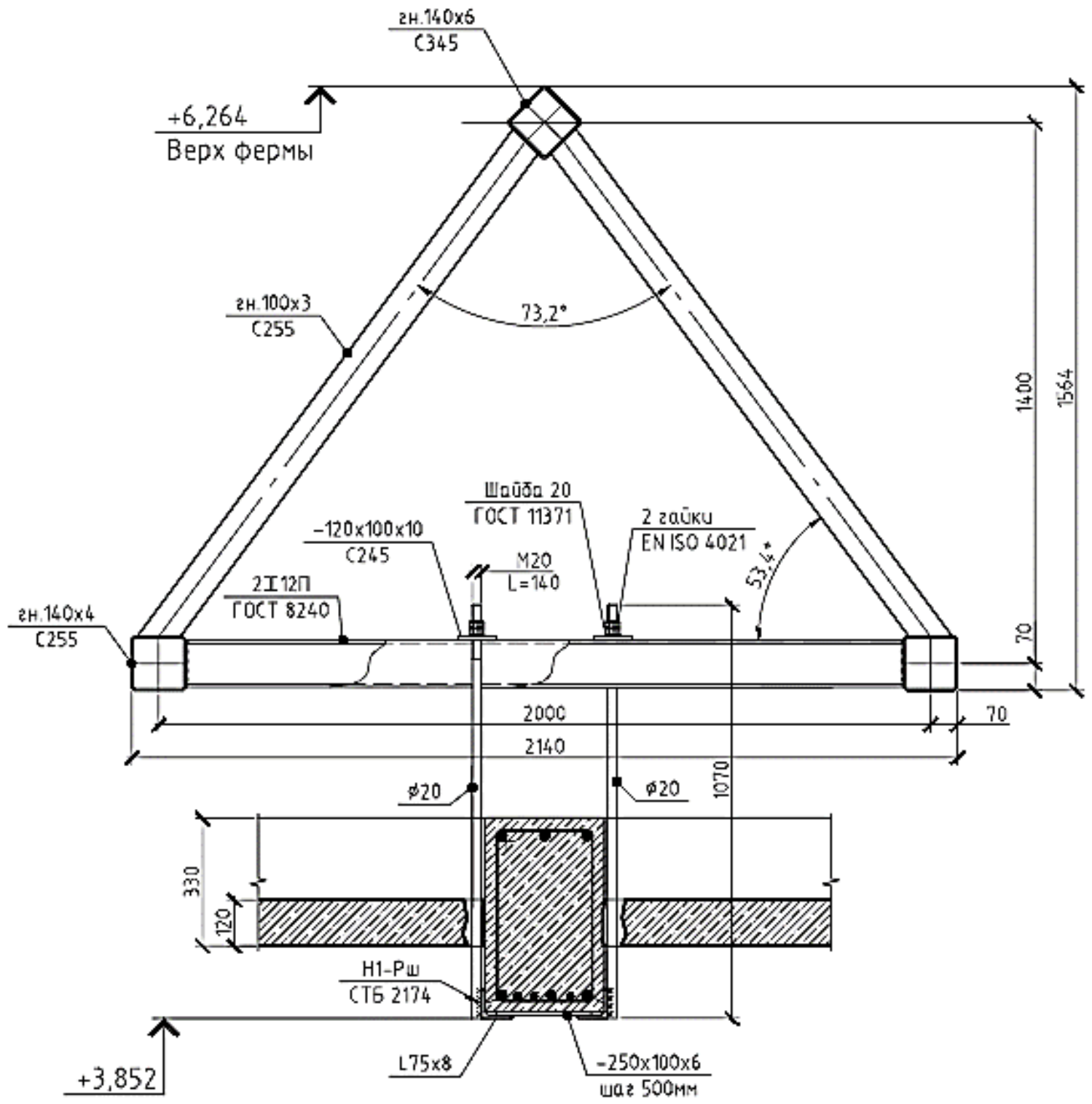

б)

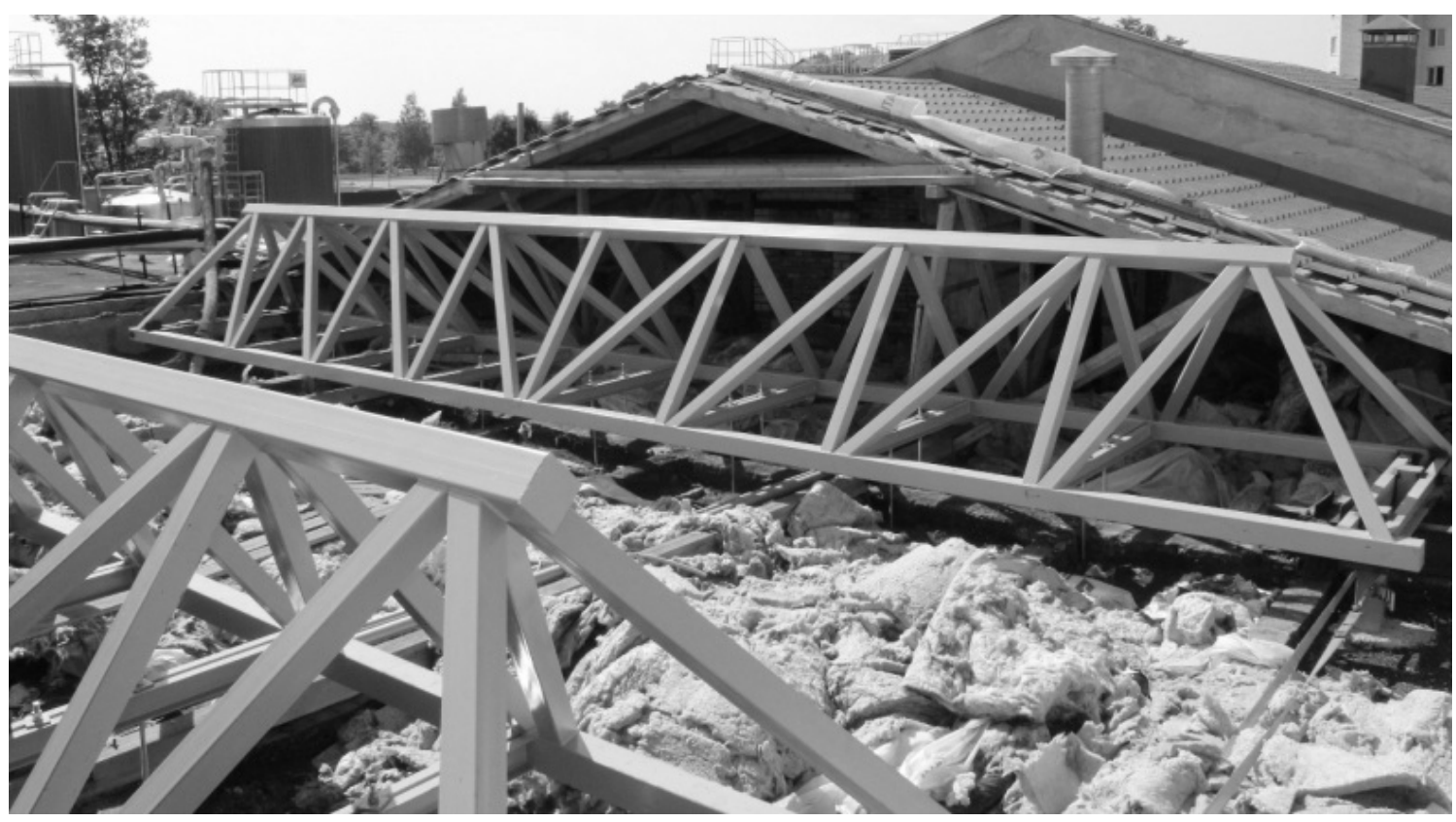

Рис. 3. Конструктивное решение (а) и общий вид трёхгранных ферм из гнутосварных профилей (б) 
3. Еврокод [3] предоставляет больше вариантов по конструированию узлов из прямоугольных труб: больший диапазон толщин труб и углов наклона решетки к поясу, возможность расчета и конструирования пространственных узлов. В [3] содержится больше вариантов разрушения узлов из прямоугольных труб, однако не по всем схемам разрушения приведены соответствующие формулы расчета, что зачастую игнорируется проектировщиками.

4. Расчет и конструирование пространственных трёхгранных ферм из труб с бесфасоночными узлами возможно только в соответствии с требованиями ТКП ЕН 1993-1-8 [3], т.к. в базе проектирования, основанной на положениях СНиП II-23-81* [1,2] конструкции пространственных узлов из прямоугольных труб не рассматриваются.

\section{Литература}

1. Строительные нормы и правила. Нормы проектирования. Стальные конструкции: СНиП ІІ-23-81*. - М.: Госстрой СССР: ЦНИТП, 1990. - 96 с.

2. Пособие по проектированию стальных конструкций (к СНиП II-23-81*). - Москва, ЦНИИСК им. Кучеренко Госстроя СССР, 1989, - 214 с.

3. Еврокод 3. Проектирование стальных конструкций. Часть 1-8. Расчет соединений : ТКП ЕN 1993-1-8-2009*. - Минск : Министерство архитектуры и строительства Республики Беларусь, 2015. - 128 с.

4. Мурашко, Н.Н. Экспериментальное исследование напряжённо-деформированного состояния бесфасоночных узлов ферм из замкнутых гнутосварных профилей / Н.Н. Мурашко, Ю.В. Соболев [и др.] // Проблемы сельскохозяйственного строительства. Тематический сборник научных трудов. - Минск, 1980.

5. Шурин, А.Б. Трёхгранные фермы из гнутосварных профилей / А.Б. Шурин, Н.Н. Шалобыта [и др.] // Вестник БрГТУ. - Брест, 2019. - № 1 : Строительство и архитектура. - с. 4749.

6. Шурин, А.Б. Сравнительный анализ расчета и проектирования элементов стальных конструкций по ТКП ЕN 1993-1 И СНиП II-23 / А.Б. Шурин, И.В. Зинкевич, А.В. Мухин // Вестник БрГТУ. - Брест, 2020. - № 1 : Строительство и архитектура. - с. 23-28.

7. Шурин, А.Б. Особенности конструирования безфасоночных узлов из прямоугольных труб по ТКП ЕN 1993-1-8 / А.Б. Шурин, А.В. Мухин, Н.Н. Шалобыта, Макаревич Е.В. // Теория и практика исследований и проектирования в строительстве с применением систем автоматизированного проектирования (САПР) : Сборник статей II Международной научнотехнической конференции (29-30 марта 2018 года) : Брест / БрГТУ - Брест, 2018. - С. 123-127.

\section{References}

[1] Stroitel'nyye normy i pravila. Normy proyektirovaniya. Stal'nyye konstruktsii: SNiP II-23-81*. M.: Gosstroy SSSR: TSNITP, 1990.

[2] Posobiye po proyektirovaniyu stal'nykh konstruktsiy (k SNiP II-23-81*). - Moskva, TSNIISK im. Kucherenko Gosstroya SSSR, 1989, - 214 s

[3] Yevrokod 3. Proyektirovaniye stal'nykh konstruktsiy. Chast' 1-8. Raschet soyedineniy : TKP EN 1993-1-8-2009*. - Minsk : Ministerstvo arkhitektury i stroitel'stva Respubliki Belarus', 2015.

[4] Murashko, N.N. Eksperimentalnoe issledovanie napryazhYonno-deformirovannogo sostoyaniya besfasonochnyih uz $\neg$ lov ferm iz zamknu $\neg$ tyih gnutosvarnyih profiley / N.N. Murash-ko, Yu.V. Sobolev [i dr.] // Problemyi selskohozyaystvennogo stroitelstva. Tematicheskiy sbornik nauchnyih trudov. - Minsk, 1980.

[5] Shuryn, A.B. Trokhgrannyye fermy iz gnutosvarnykh profiley / A.B. Shuryn, N.N. Shalobyta [i dr.] // Vestnik BrGTU. - Brest, 2019.

[6] Shuryn, A.B. Sravnitel'nyy analiz rascheta i proyektirovaniya elementov stal'nykh konstruktsiy po TKP EN 1993-1 I SNiP II-23 / A.B. Shuryn, I.V. Zinkevich, A.V. Mukhin // Vestnik BrGTU. Brest, 2020. 
[7] Shuryn, A.B. Osobennosti konstruirovaniya bezfasonochnykh uzlov iz pryamougol'nykh trub po TKP EN 1993-1-8 / A.B. Shuryn, A.V. Mukhin [i dr.] // Teoriya i praktika issledovaniy i proyektirovaniya $\mathrm{V}$ stroitel'stve $\mathrm{s}$ primeneniyem sistem avtomatizirovannogo proyektirovaniya (SAPR) : Sbornik statey II Mezhdunarodnoy nauchno-tekhnicheskoy konferentsii (29-30 marta 2018 goda) : Brest / BrGTU - Brest, 2018.

\title{
ДОСВІД КОНСТРУЮВАННЯ ФЕРМ ІЗ ГНУТОЗВАРНИХ ПРОФІЛЕЙ У ВІДПОВІДНОСТІ ДО ВИМОГ ЕN 1993-1
}

\author{
Шурин А.Б. к.т.н., доцент, \\ shuryn@mail.ru, ORCID: 0000-0003-1396-3503 \\ Мухін А.В., к.т.н., доцент, \\ «Брестський державний технічний університет» \\ myhinanatoli@tut.by
}

\begin{abstract}
Анотація. Історія застосування сталевих ферм становить кілька сотень років. Сучасна практика будівництва показала, що найбільш економічні сталеві зварні ферми з прямокутних труб внаслідок своєї технологічності і відносно невеликої витрати матеріалу. В даний час в Республіці Білорусь, в залежності від завдання на проектування, розрахунок сталевих конструкцій допускається виконувати як відповідно до вимог СНиП II-23, так і по ТКП ЕN 19931. У статті наведено зіставлення конструктивних рішень ферм з прямокутних труб з безфасоночнимі вузлами, запроектованих по ТКП ЕN 1993 і СНиП II-23, і застосованих на різних об'єктах Республіки Білорусь. Виконано аналіз найбільш часто зустрічаються помилок при їх проектуванні.

Перетин гнутозварного профілю є ідеальним для тригранної призматичної стрижневої конструкції з точки зору простоти організації вузлового просторового з'єднання. ТКП ЕN 1993-1-8 надає можливість розрахунку і конструювання просторових бесфасоночних вузлів: типу КК, ТT і XX. Застосування трикутних ферм з такими вузлами в каркасах будівель дозволяє зменшити витрати на пристрій в конструкціях покриття зв'язків або повністю виключити поперечні зв'язки по покриттю.

Встановлено, що Сврокод надає більше варіантів по конструюванню вузлів 3 прямокутних труб: більший діапазон товщин труб і кутів нахилу решітки до поясу, можливість розрахунку і конструювання просторових вузлів. ТКП ЕN 1993-1-8 містить більше варіантів руйнування вузлів $з$ прямокутних труб, проте не за всіма схемами руйнування наведені відповідні формули розрахунку, що часто ігнорується проектувальниками.

Представлено конструктивне рішення розробленого і реалізованого авторами конструктивного рішення по посиленню монолітного ребристого горищного перекриття з використанням просторових тригранних ферм з гнутозварних профілів, запроектованих з використанням ТКП ЕN 1993-1.

Основна ідея посилення горищного перекриття, що знаходиться в аварійній ситуації, полягала в його підвішуванні до самостійних несучих конструкцій у вигляді тригранних ферм, що спираються на вертикальні несучі елементи. Включення в роботу всієї конструкції посилення проводиться шляхом натягу підвісок, на яких підвішена нерозрізна головна балка монолітного ребристого горищного перекриття.
\end{abstract}

Ключові слова: ферми, вузли, гнутосварних профілі, Сврокод, несуча здатність, продавлювання, міцність, втрата місцевої стійкості. 


\title{
EXPERIENCE OF DESIGNING STEEL TRUSSES FROM RECTANGULAR HOLLOW SECTIONS ACCORDING TO EN 1993-1 REQUIREMENTS
}

\author{
Shuryn A.B., Ph.D, \\ shuryn@mail.ru, ORCID: 0000-0003-1396-3503 \\ Muhin A.V., Ph.D, \\ Brest State Technical University, Brest, Republic of Belarus \\ myhinanatoli@tut.by
}

\begin{abstract}
The history of using steel trusses is several hundred years. Modern construction practice has shown that steel welded trusses made of rectangular pipes are the most economical due to their manufacturability and relatively low material consumption. Currently, in the Republic of Belarus, depending on the design assignment, the calculation of steel structures is allowed to be performed both in accordance with the requirements of SNiP II-23, and according to the EN 1993-1 TRC. The article presents a comparison of structural solutions of trusses made of rectangular pipes with faceless nodes, designed according to the EN 1993 and SNiP II-23, and applied at various facilities in the Republic of Belarus. The analysis of the most common errors in their design is performed.

The cross section of the bent-welded profile is ideal for a three-sided prismatic rod structure in terms of ease of organization of the nodal spatial connection. The EN 1993-1-8 provides the ability to calculate and design spatial faceless nodes: type KK, TT and XX. The use of triangular trusses with such nodes in the frames of buildings allows you to reduce the cost of the device in the structure of the coating connections or completely eliminate cross-links on the coating.

It is found that the Eurocode provides more options for designing nodes from rectangular pipes: a greater range of pipe thicknesses and angles of inclination of the grid to the belt, the possibility of calculating and designing spatial nodes. Tap EN 1993-1-8 contains more variants of destruction of nodes from rectangular pipes, but not all schemes of destruction are given the corresponding calculation formulas, which is often ignored by designers.

The paper presents a design solution developed and implemented by the authors of a structural solution for strengthening a monolithic ribbed attic floor with the use of spatial three-sided trusses made of bent-welded profiles, designed using the EN 1993-1.

The main idea of strengthening the attic floor, which is in an emergency, was to hang it to independent load-bearing structures in the form of three-sided trusses, based on vertical load-bearing elements. Inclusion in the work of the entire structure of the reinforcement is made by stretching the suspensions, which are suspended unbroken main beam of the monolithic ribbed attic floor.
\end{abstract}

Keyword: trusses, joint of a truss, bent profiles, Eurocode, load-carrying capacity, punching, strength, loss of local stability. 


\title{
ОПТИМІЗАЦІЯ ВИСОТИ СТАЛЕВОЇ ЗВАРНОЇ ДВОТАВРОВОЇ БАЛКИ НА ДІЛЯНКАХ БІЛЯ ОПОР
}

\author{
Янін О.С., - к.т.н., доцент, \\ Херсонський Державний Аграрний Університет, м. Херсон \\ yanin_a@ukr.net, ORCID ID 0000-0003-0230-8669 \\ Новікова С.М., - старший викладач, \\ Херсонський Державний Аграрний Університет, м. Херсон \\ novikova_svetla@ukr.net, ORCID ID 0000-0003-0012-521X
}

Анотація. У статті наведені результати оптимізації за витратами сталі однопролітної шарнірно-обпертої балки при рівномірно-розподіленому навантаженні за рахунок зменшення iii висоти біля опор. Визначався найменший нахил нижнього поясу виходячи 3 того, щоб у будь якому місці за довжиною балки була забезпечена міцність за нормальними напруженнями. Запропонована методика визначення висоти балки на опорі, яка задовольняє умові міцності на зріз та відповідає мінімальним витратам сталі на балку. Ефективність зменшення висоти балки на ділянках біля опор оцінювалась коефіцієнтом, який являє собою відношення мінімальної висоти балки з умови міцності на зріз до висоти балки посередині прольоту. Зменшення висоти балки на ділянках біля опор рекомендується при відносно малих навантаженнях та гнучкостях стінки і відносно великих прольотах.

Ключові слова: оптимізація, згин, висота балки, гнучкість стінки, нахил нижнього поясу, міцність на зріз.

Вступ. В умовах ринкової економіки достатньо актуальним стає зменшення витрат матеріалу на будівельні конструкції. При їх масовому серійному виготовленні економічний ефект, отриманий за рахунок економії матеріалу, може зіграти важливу роль. Тому доцільно розглянути можливість проектування сталевих зварних балок виходячи з мінімальних витрат сталі.

Аналіз останніх джерел досліджень і публікацій. Задачі раціонального проектування сталевих балок, що працюють на згин вирішуються у ряді праць провідних вітчизняних та закордонних вчених [1-4]. Зокрема, для економії матеріалу пропонується зменшувати розміри поперечного перерізу балки у місцях зменшення згинальних моментів. Частіше виконується зменшення ширини або товщини поясів, оскільки такий варіант є найбільш простий. При рівномірному розподіленні навантаження найбільш вигідне місце зміни розмірів поясів знаходиться на відстані приблизно 1/6 прольоту балки від опори [5-7]. Зменшення висоти балки може привести до необхідності збільшення товщини стінки біля опор для сприйняття дотичних напруг, що у деяких випадках $є$ технологічно недоцільним. [5-7].

Виділення не розв'язаних раніше частин загальної проблеми. Актуальним $\epsilon$ дослідження можливості підбору параметрів зменшення висоти балки біля опор виходячи із забезпечення технологічних та економічних вимог при незмінній товщині стінки. Доцільно також визначити місце у прольоті, де вигідно почати зменшення висоти балки.

Постановка завдання Розглянемо однопролітну шарнірно-обперту балку, завантажену рівномірно-розподіленим лінійним навантаженням (рис.1). 


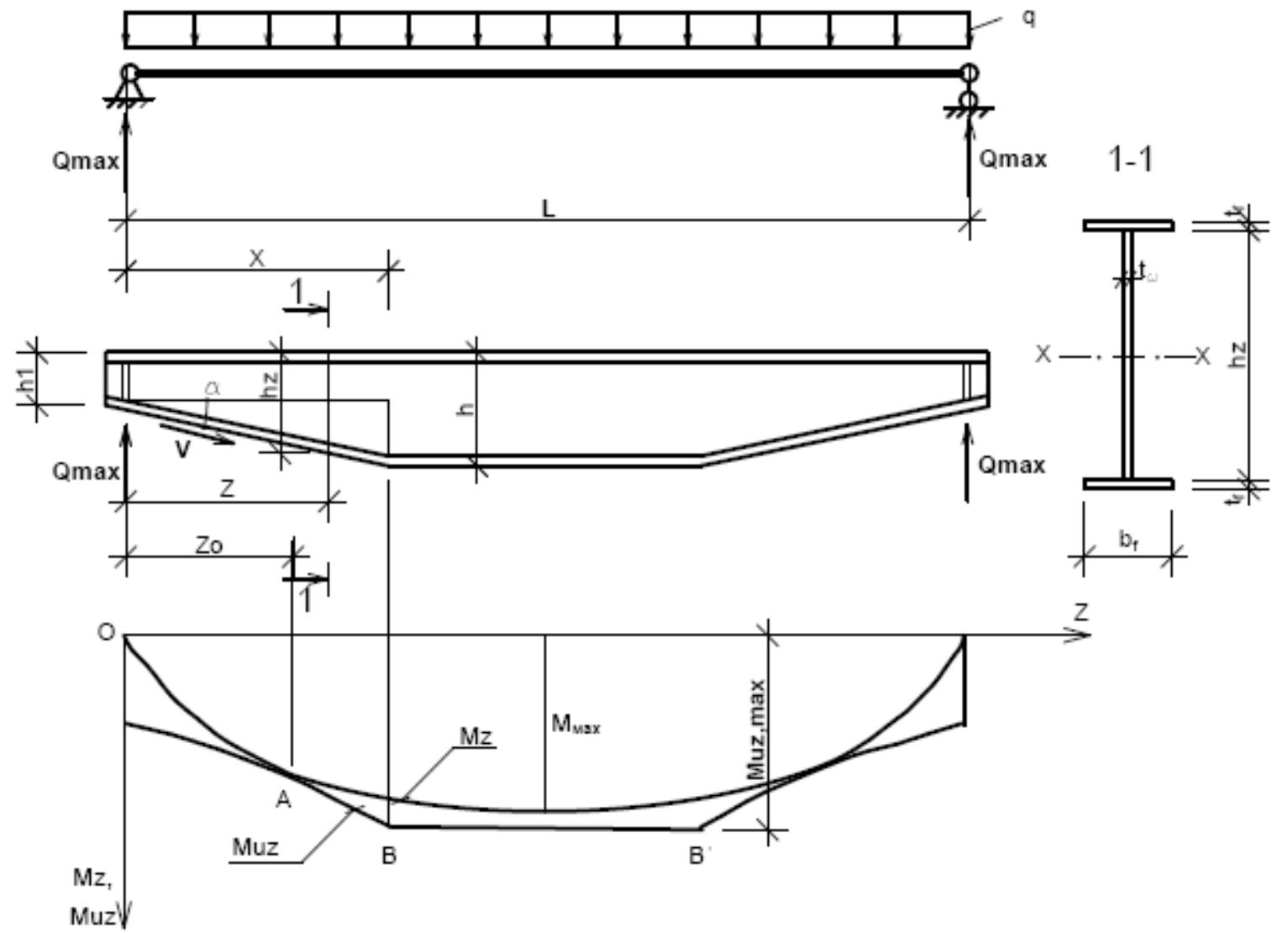

Рис. 1. Схема балки

Припустимо, що iï складений двотавровий поперечний переріз підібраний по максимальному згинальному моменту посередині прольоту $\left(\mathrm{M}_{\max }\right)$ iз умови міцності за нормальними напруженнями [8]. 3 віддаленням від середини прольоту до опор згинальні моменти (М) зменшуються. Отже зменшується потрібний момент опору

$$
W_{\text {nomp }}=\frac{M}{R_{Y} \gamma_{c}} \text {, }
$$

де $\mathrm{R}_{\mathrm{y}}$ - розрахунковий опір сталі стиску, розтягу та згину за межею текучості;

$\gamma_{\mathrm{c}}-$ коефіцієнт умов роботи.

Тому, з метою економії сталі можна зменшувати розміри поперечного перерізу балки на приопорних ділянках [5]. Це досягається, зокрема, за рахунок зменшення іiї висоти (h). Для рішення задачі, складемо функцію витрат сталі та визначимо іiі мінімум. Це дозволить підібрати оптимальну висоту балки у опор і ухил нижнього поясу при мінімальних витратах матеріалу.

Основний матеріал і результати. Виходячи з умови міцності на зріз, прийнята висота балки на опорі повинна задовольняти умові [5]

$$
h_{1} \geq \frac{n Q_{\max }}{R_{s} \gamma_{c} t_{\omega}}=h_{s, \min }
$$

де $\mathrm{R}_{\mathrm{s}}$ - розрахунковий опір сталі на зріз;

$\mathrm{h}_{\mathrm{s}, \min }-$ мінімальна висота балки із умови міцності на зріз. 
Якщо розрізна балка обпирається на нижче розташовану конструкцію за допомогою опорного ребра, привареного до торця, то в опорному поперечному перерізі дотичні напруження сприймає тільки стінка і n=1,5.

Якщо опорне ребро заведено між полками на деякій відстані від торця, то в опорному поперечному перерізі дотичні напруження сприймає як стінка, так і полиці. Тоді $\mathrm{n}=1,5$.

3 рис.1 видно, що висота балки на відстані Z від опори

$$
h_{z}=h_{1}+V Z
$$

де $\mathrm{V}=\operatorname{tg} \alpha$ нахил нижнього поясу балки на при опорних ділянках.

Несуча здатність балки (максимальний згинальний момент, який може сприйняти поперечний переріз) на відстані Z від опори

$$
M_{u z}=W_{z} R_{y} \gamma_{c}
$$

де $\mathrm{W}_{\mathrm{z}}$-момент опору поперечного перерізу на відстані $\mathrm{Z}$ від опори;

$$
W_{z}=\frac{I_{z}}{0.5 h_{z}}
$$

$\mathrm{I}_{\mathrm{z}}$ - відповідний момент інерції;

$$
I_{z}=\frac{t_{\omega} h_{z}^{3}}{12}+2 b_{f} t_{f}\left(\frac{h_{z}}{2}\right)^{2}
$$

Формула для $\mathrm{I}_{z} \in$ наближеною так як у ній прийнято, що $\mathrm{h}_{\omega} \approx \mathrm{h}$.

Тоді

$$
M_{u z}=R_{y} \gamma_{c}\left(\frac{t_{\omega} h_{z}^{2}}{6}+b_{f} t_{f} h_{z}\right)
$$

3 урахуванням формули (3)

$$
M_{u z}=R_{y} \gamma_{c}\left[\frac{t_{\omega}\left(h_{1}+V Z\right)^{2}}{6}+b_{f} t_{f}\left(h_{1}+V Z\right)\right] .
$$

При фіксованому $\mathrm{h}_{1}$ та зменшенні нахилу нижнього поясу $\mathrm{V}$, витрати сталі на балку знижуються. Тому слід знайти найменше значення $\mathrm{V}$, при якому в будь якому місці за довжиною балки була б забезпечена міцність за нормальними напруженнями, тобто виконана умова

$$
\frac{M_{z}}{W_{z}} \leq R_{y} \gamma_{c}
$$


або

$$
M_{z} \leq W_{z} R_{y} \gamma_{c}=M_{u z}
$$

де $\mathrm{M}_{\mathrm{z}}$ - згинальний момент від розрахункового навантаження на відстані $\mathrm{Z}$ від опори;

$$
M_{z}=\frac{1}{2} q Z(L-Z)
$$

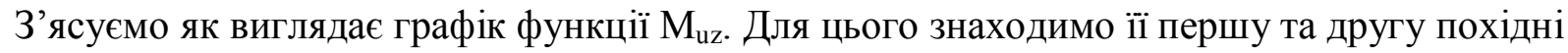

$$
\begin{gathered}
\frac{d M_{u z}}{d Z}=R_{y} \gamma_{c}\left[\frac{t_{\omega}\left(h_{1}+V Z\right) V}{3}+b_{f} t_{f} V\right] \\
\frac{d^{2} M_{u z}}{d Z^{2}}=R_{y} \gamma_{c} \frac{t_{\omega} V^{2}}{3} .
\end{gathered}
$$

При будь якому $\mathrm{Z}>0$ друга похідна $\frac{d^{2} M_{u z}}{d Z^{2}}>0$. Тому графік функції $\mathrm{M}_{\mathrm{uz}} \epsilon$ вгнутий по відношенню до вертикальної осі ординат, яка направлена вниз (див. рис.1). Графік функції $\mathrm{M}_{\mathrm{z}} \epsilon$ випуклий по відношенню до тієї же осі тому що $\frac{d^{2} M_{z}}{d Z^{2}}=-q<0$ при будь якому Z.

3 формули (8) випливає, що при фіксованому $\mathrm{Z}$ та зменшенні $\mathrm{V}, \mathrm{M}_{\mathrm{uz}}$ зменшується. Це означає, що графік функції $\mathrm{M}_{\mathrm{uz}}$ наближається до горизонтальної осі абсцис по мірі зниження $\mathrm{V}$.

При цьому можна знайти таке значення $\mathrm{V}=\mathrm{V}_{0}$, при якому графік функції $\mathrm{M}_{\mathrm{uz}}$ доторкнеться графіка функції $\mathrm{M}_{\mathrm{z}}$ у деякій точці А на відстані $\mathrm{Z}$ від опори. У цій точці буде виконуватись рівність

$$
\mathrm{M}_{\mathrm{uz}}=\mathrm{M}_{\mathrm{z}}
$$

3 графіків функцій $\mathrm{M}_{\mathrm{uz}}$ та $\mathrm{M}_{\mathrm{z}}$ (перший - вгнутий, а другий - випуклий) випливає, що у решті точок по довжині балки буде виконуватись умова міцності за нормальними напруженнями

$$
M_{z} \leq M_{u z}
$$

Якщо далі зменшувати $\mathrm{V}$ (тобто приймати $\mathrm{V}<\mathrm{V}_{0}$ ), то у точці $\mathrm{A} \mathrm{M}_{\mathrm{uz}}$ стане менше ніж $\mathrm{M}_{\mathrm{z}}$, тобто міцність забезпечена не буде. Тому, значення $\mathrm{V}=\mathrm{V}_{0}$, при якому у точці $\mathrm{A}_{\mathrm{z}}=\mathrm{M}_{\mathrm{uz}} \epsilon$ мінімально допустимим та відповідає мінімуму витрат сталі при фіксованій висоті балки на опорі $\mathrm{h}_{1}$.

Коли обидва графіка доторкаються один до іншого у точці A, їх перші похідні у цій точці однакові: 


$$
\frac{d M_{z}}{d Z}=\frac{d M_{u z}}{d Z}
$$

Розв'язавши спільно рівняння (14) і (16) можна знайти мінімально допустиме значення $\mathrm{V}=\mathrm{V}_{0}$ та величину $\mathrm{Z}=\mathrm{Z}_{0}$.Відповідна система двох рівнянь 3 двома невідомими $\mathrm{V}_{0}$ та $\mathrm{Z}_{0}$ має вигляд:

$$
\left\{\begin{array}{c}
\frac{1}{2} q Z_{0}\left(L-Z_{0}\right)=R_{y} \gamma_{c}\left[\frac{t_{\omega}\left(h_{1}+V_{0} Z_{0}\right)^{2}}{6}+b_{f} t_{f}\left(h_{1}+V_{0} Z_{0}\right)\right] \\
\frac{1}{2} q\left(L-2 Z_{0}\right)=R_{y} \gamma_{c}\left[\frac{t_{\omega}\left(h_{1}+V_{0} Z_{0}\right) V_{0}}{3}+b_{f} t_{f} V_{0}\right]
\end{array} .\right.
$$

Після іiі розв'язання отримаємо:

$$
\begin{gathered}
V_{0}=\frac{q L}{2 R_{y} \gamma_{c} b_{f} t_{f}}\left[(1+p)-\sqrt{(2+p)\left(p+Q_{1}\right)}\right], \\
Z_{0}=\frac{0,5 q L-R_{y} \gamma_{c} V_{0} b_{f} t_{f}(1+p)}{\frac{1}{3} R_{y} \gamma_{c} t_{\omega} V_{0}^{2}+q},
\end{gathered}
$$

де

$$
p=\frac{h_{1} t_{\omega}}{3 b_{f} t_{f}} ; \quad Q_{1}=\frac{4 R_{y} \gamma_{c} h_{1} b_{f} t_{f}}{q L^{2}} .
$$

Розв'язання системи рівнянь (17) у загальному вигляді являє собою достатньо складну алгебраїчну задачу. Спростити його можна за допомогою комп'ютерної програми MathCAD. Для цього слід застосувати команди Given та Find.

При деякому значенні $\mathrm{Z}=\mathrm{X}$ (див.рис.1) висота балки $\mathrm{h}_{\mathrm{z}}$ буде дорівнювати величині $\mathrm{h}$, яка отримана при підборі поперечного перерізу посередині прольоту по максимальному згинальному моменту. Тоді (див. формулу (3))

$$
\begin{gathered}
h_{z}=h_{1}+V_{0} X=h ; \\
X=\frac{h-h_{1}}{V_{0}} .
\end{gathered}
$$

При $\mathrm{Z}>\mathrm{X}$ висота балки залишається постійною та дорівнює h. Тому і несуча здатність балки між точками В та В' у середній частині прольоту буде постійною та рівною 


$$
M_{u z, \max }=R_{y} \gamma_{c}\left[\frac{t_{\omega} h^{2}}{6}+b_{f} t_{f} h\right] .
$$

Ця величина небагато більша за $\mathrm{M}_{\max }$, тому що підбір розмірів поперечного перерізу виконується $з$ деяким запасом міцності.

Висота балки на опорі $\mathrm{h}_{1}$, яка задовольняє умові міцності на зріз (див. формулу (2)), може приймати різні значення. Тому можна спробувати знайти таке з них, при якому витрати сталі на балку будуть мінімальними. Для цього слід задатися рядом значень $\mathrm{h}_{1} 3$ деяким кроком, і при кожному з них знайти свої значення $\mathrm{V}_{0}$ та $\mathrm{X}$, які відповідають доторканню графіків функцій $\mathrm{M}_{\mathrm{uz}}$ та $\mathrm{M}_{\mathrm{z}}$.

Функція витрат сталі на половину балки має вигляд:

$$
\begin{gathered}
m_{\sigma}=\rho_{c m}\left\{t_{\omega}\left[\left(h-2 t_{f}\right)\left(\frac{L}{2}-X\right)+X\left(\frac{h+h_{1}}{2}-2 t_{f}\right)\right]+\right. \\
\left.+b_{f} t_{f}\left[L-X+\sqrt{X^{2}+\left(h-h_{1}\right)^{2}}\right]\right\},
\end{gathered}
$$

де $\rho_{\text {ст }}-$ питома вага сталі.

Задача була розв'язана за допомогою комп'ютерної програми МathCAD при контрольних вихідних даних. Побудований графік залежності $\mathrm{m}_{\sigma}$ від $\mathrm{h}$, який має чітко виражений мінімум. Його загальний вигляд наведений на рис.2.

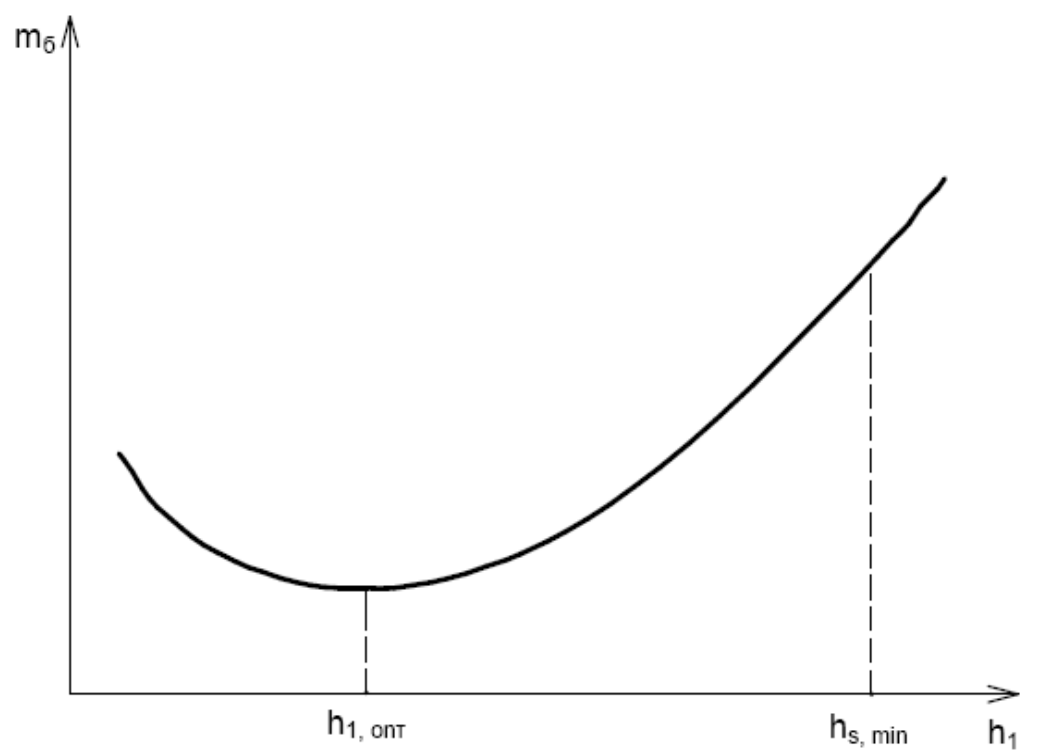

Рис. 2. Загальний вигляд графіку залежності то від $\mathrm{h}$

Якщо значення $\mathrm{h}_{1}$, що відповідає цьому мінімуму $\left(\mathrm{h}_{1,0 п т}\right)$ менше за мінімальну висоту балки з умови міцності на зріз (див. формулу (2)),

$$
h_{s, \min }=\frac{n Q_{\max }}{R_{s} \gamma_{c} t_{\omega}}
$$


то, як видно 3 графіка, мінімальним витратам сталі відповідає $\mathrm{h}_{1}=\mathrm{h}_{\mathrm{s}, \min }$ (приймати $\mathrm{h}_{1}<\mathrm{h}_{\mathrm{s}, \min }$ не можна). У протилежному випадку мінімальним витратам сталі відповідає $\mathrm{h}_{1}=$ $\mathrm{h}_{\text {1опт. }}$.

Ефективність зменшення висоти балки на ділянках біля опор тим більша, чим менше $\mathrm{h}_{\mathrm{s}, \min }$ порівняно $3 \mathrm{~h}$, тобто чим менше відношення

$$
k=\frac{h_{s, \min }}{h} \text {. }
$$

У цьому випадку графік функції несучої здатності балки $\mathrm{M}_{\mathrm{uz}}$ буде розташований ближче до епюри згинальних моментів від розрахункового навантаження $\mathrm{M}_{\mathrm{z}}$ (див. рис 1), що відповідає меншим витратам сталі.

3'ясуємо, при яких параметрах балки коефіцієнт "К” $\epsilon$ відносно невеликий. У відповідності з традиційним підходом висоту балки посередині прольоту знаходять виходячи 3 мінімуму витрат сталі по формулі [7]

$$
h=\sqrt[3]{\frac{3}{2} \lambda_{\omega} W_{n o m p}},
$$

де $\lambda_{\omega}$ - задана постійна гнучкість стінки;

$\mathrm{W}_{\text {потр }}-$ потрібний момент опору з умови міцності за нормальними напруженнями;

$$
\begin{gathered}
W_{\text {nomp }}=\frac{M_{\max }}{R_{y} \gamma_{c}}=\frac{q L^{2}}{8 R_{y} \gamma_{c}}, \\
M_{\max }=\frac{q L^{2}}{8} .
\end{gathered}
$$

3 формул (27) та (28) отримаємо

$$
h=\sqrt[3]{\frac{3}{2} \lambda_{\omega} \frac{q L^{2}}{8 R_{y} \gamma_{c}}} .
$$

3 урахуванням того, що

$$
Q_{\max }=\frac{q L}{2}{ }_{\text {та }} t_{\omega}=\frac{h}{\lambda_{\omega}}
$$

3 формули (25) маємо

$$
h_{s, \min }=\frac{n q L}{2 R_{s} \gamma_{c}} \frac{\lambda_{\omega}}{h} .
$$


Підставляємо $\mathrm{h}_{\mathrm{s}, \min }$ та h у формулу (26)

$$
k=\frac{h_{s, \min }}{h}=\frac{n q L}{2 R_{s} \gamma_{c}} \frac{\lambda_{\omega}}{h^{2}}=2 n \sqrt[3]{\frac{4}{9} \frac{q R_{y}{ }^{2} \lambda_{\omega}}{L R_{s}{ }^{3} \gamma_{c}}}
$$

Висновки. 3 формули (33) видно, що чим менше лінійне навантаження q та гнучкість стінки $\lambda_{\omega}$ та чим більше проліт L, тим K менше. Тому, зменшення висоти балки на ділянках біля опор рекомендується при відносно малих навантаженнях та гнучкостях стінки та відносно великих прольотах.

Встановлено, що чим менше $\mathrm{n}$, тим менше К. Тому, опорний вузол балки рекомендується конструювати таким чином, щоб опорне ребро не приварювалось до торця (коли $\mathrm{n}=1.5)$, а було заведене між полицями на деякій відстані від торця (коли $\mathrm{n}=1.2$ ).

\section{Література}

1. Металеві конструкції: підруч. [для студ. вищ. навч. закл.] / Нілов О.О., Пермяков В.О., Шимановський О.В. та ін.. - К.: Вид-во «Сталь», 2010. - 869 с.

2. Зорин 3.Я. Стальные конструкции. Проектирование на стадии КМД / 3.Я. Зорин, А.А. Новицкий. - Киев: Сталь, 2015 - 268 с.

3. Гоголь М.В. Регулювання зусиль у металевих конструкціях / М.В. Гоголь, М.Р. Більський, С.I. Віхоть, М.М. Гоголь // Вісник національного університету «Львівська політехніка» «Теорія і практика будівництва». - Львів, 2012. - №737. - С.64-70.

4. Максимов Ю.С. Исследование несущей способности стальных двутавровых балок с вертикально гофрированной стенкой / Ю.С. Максимов, Г.М. Остриков, В.В. Долинский // Строительная механика и расчет сооружений. 1983. - №1. - С. 68-70.

5. Металлические конструкции. Общий курс: Учебник для вузов /Е.И. Беленя, В.А. Балдин, Г.С. Ведеников и др.; Под. общ. ред. Е.И. Беленя. 6-е изд., перераб. и доп. - М.: Стройиздат, 1986. - 560 с., ил.

6. Металлические конструкции. Н.С. Стрелецкий, А.Н. Гениев, Е.И. Беленя, В.А. Балдин, Е.Н. Лессиг ; Под. общ. ред. Н.С. Стрелецкого. 3-е изд., перераб. - М.: Стройиздат, 1961. - 776 с., ил.

7. Муханов К.К. Металлические конструкции. Учебник для вузов. Изд. 3-е, испр. и доп. М., Стройиздат, 1978. 572 с.

8. ДБН В.2.6-198:2014. Сталеві конструкції. Норми проектування». - Київ: Міністерство регіонального розвитку та будівництва України, 2014. - 199с.

\section{References}

[1] Nilov O.O., Permyakov V.O., Shymanovskyy O.V, "Metalevi konstruktsiyi: pidruch. [dlya stud. vyshch. navch. zakl.]", Kyev, Stal, 2010.

[2] Z.YA. Zoryn, A.A. Novytskyy, "Stalnye konstruktsyy. Proektyrovanye na stadyy KMD", Kyev, Stal, 2015.

[3] M.V. Hohol, M.R. Bilskyy, S.I. Vikhot, M.M. Hohol, "Rehulyuvannya zusyl u metalevykh konstruktsiyakh", Visnyk natsionalnoho universytetu «Lvivska politekhnika» «Teoriya i praktyka budivnytstva» vol. 737, Lviv, 2012.

[4] YU.S. Maksymov, H.M. Ostrykov, V.V. Dolynskyy "Yssledovanye nesushchey sposobnosty stalnykh dvutavrovykh balok s vertykalno hofryrovannoy stenkoy", Stroytelnaya mekhanyka y raschet sooruzhenyy, pp. 68-70, vol. 1, 1983. 
[5] E.Y. Belenya, V.A. Baldyn, H.S. Vedenykov, "Metallycheskye konstruktsyy. Obshchyy kurs: Uchebnyk dlya vuzov", M.: Stroyyzdat, 1986.

[6] N.S. Streletskyy, A.N. Henyev, E.Y. Belenya, V.A. Baldyn, E.N. Lessyh,” Metallycheskye konstruktsyy", M.: Stroyyzdat, 1961.

[7] K.K. Mukhanov, "Metallycheskye konstruktsyy", M., Stroyyzdat, 1978.

[8] DBN V.2.6-198:2014. Stalevi konstruktsiyi. Normy proektuvannya». - Kyiv: Ministerstvo rehionalnoho rozvytku ta budivnytstva Ukrayiny, 2014.

\title{
ОПТИМИЗАЦИЯ ВЫСОТЫ СТАЛЬНОЙ СВАРНОЙ ДВУТАВРОВОЙ БАЛКИ НА УЧАСТКАХ ВОЗЛЕ ОПОР
}

\author{
Янин А.Е., - к.т.н., доцент, \\ Херсонский Государственный Аграрный Университет г. Херсон \\ yanin_a@ukr.net, ORCID ID 0000-0003-0230-8669 \\ Новикова С.Н., - старший преподаватель, \\ Херсонский Государственный Аграрный Университет г. Херсон \\ novikova_svetla@ukr.net, ORCID ID 0000-0003-0012-521X
}

Аннотация. В статье приведены результаты оптимизации по расходу стали однопролетной шарнирно-опертой балки, загруженной равномерно-распределенной линейной нагрузкой. Предполагалось, что ее составное двутавровое поперечное сечение подобрано по максимальному изгибающему моменту посередине пролета из условия прочности по нормальным напряжениям. Учтено, что при удалении от середины пролета к опорам, изгибающие моменты уменьшаются. Соответственно уменьшается необходимый момент сопротивления.

Исследование опиралось на то, что в целях экономии стали можно уменьшать размеры поперечного сечения балки на участках возле опор. Это достигалось за счет уменьшения ее высоты.

Были учтены ограничения на высоту балки на опоре, исходя из условия прочности на срез.

Определялся минимальный уклон нижнего пояса исходя из того, чтобы в любом месте по длине балки была обеспечена прочность по нормальным напряжениям. Это связано с тем, что при фиксированной высоте балки на опоре и уменьшении уклона нижнего пояса, расход стали на балку снижается. Для решения такой задачи, получена аналитическая формула для несущей способности балки в виде максимального изгибающего момента, который может воспринять поперечное сечение на определенном расстоянии от опоры.

Уклон нижнего пояса подбирался таким образом, чтобы изгибающий момент от нагрузки в каждой точке пролета не превышал несущей способности балки.

Предложена методика определения высоты балки на опоре, которая удовлетворяет условию прочности на срез и соответствует минимальному расходу стали на балку. Для этого составлена функция расхода стали на половину балки и определялся ее минимум. Приведены рекомендации к решению этой задачи с помощью компьютерной программы. Построен график зависимости функции расхода стали от высоты балки, который имеет минимум.

Эффективность уменьшения высоты балки на участках вблизи опор оценивалась коэффициентом, который представляет собой отношение минимальной высоты балки из условия прочности на срез к высоте балки посередине пролета. Чем меньше этот коэффициент, тем ближе к эпюре изгибающих моментов от расчетной нагрузки будет расположен график функции несущей способности. В таком случае расход стали будет меньше.

Установлено, что при уменьшении линейной нагрузки на балку и гибкости стенки, а также при увеличении пролета, указанный коэффициент становится меньше. Поэтому, 
уменьшение высоты балки на участках вблизи опор рекомендуется выполнять при относительно малых нагрузках и гибкости стенки и относительно больших пролетах.

Ключевые слова: оптимизация, изгиб, высота балки, гибкость стенки, уклон нижнего пояса, прочность на срез.

\title{
HEIGHT OPTIMIZATION OF A STEEL WELDED I-BEAM IN AREAS AT THE SUPPORTS
}

\author{
Yanin A.E., - PhD, Assistant Professor, \\ Kherson State Agrarian University, Kherson \\ yanin_a@ukr.net, ORCID ID 0000-0003-0230-8669 \\ Novikova S.N., - Senior Lecturer, \\ Kherson State Agrarian University, Kherson \\ novikova_svetla@ukr.net, ORCID ID 0000-0003-0012-521X
}

\begin{abstract}
The article presents the results of optimization of the consumption of steel of a single-span articulated beam loaded with a uniformly distributed linear load. It was assumed that its composite I-beam cross section was selected according to the maximum bending moment in the middle of the span from the condition of strength at normal stresses. It is taken into account that when moving away from the middle of the span to the supports, bending moments decrease. Accordingly, the necessary moment of resistance decreases.

The study relied on the fact that in order to save steel, it is possible to reduce the crosssectional dimensions of the beam in areas near the supports. This was achieved by reducing its height.
\end{abstract}

The restrictions on the height of the beam on the support were taken into account, based on the condition of shear strength.

The minimum slope of the lower belt was determined based on the fact that in any place along the length of the beam strength at normal stresses was ensured. This is due to the fact that with a fixed height of the beam on the support and a decrease in the slope of the lower belt, the consumption of steel on the beam decreases. To solve this problem, an analytical formula is obtained for the bearing capacity of the beam in the form of a maximum bending moment, which can perceive a cross section at a certain distance from the support.

The slope of the lower belt was selected so that the bending moment from the load at each point of span did not exceed the load-bearing capacity of the beam.

A technique is proposed for determining the height of the beam on the support, which satisfies the condition of shear strength and corresponds to the minimum consumption of steel on the beam. For this, the function of steel consumption for half the beam was compiled and its minimum was determined. Recommendations are given for solving this problem using a computer program. The graph of the dependence of the function of steel consumption from the beam height was constructed. This graph has a minimum.

The effectiveness of reducing the height of the beam in areas near the supports was estimated by a coefficient that is the ratio of the minimum height of the beam from the condition of shear strength to the height of the beam in the middle of the span. The smaller this coefficient, the closer to the plot of bending moments from the calculated load will be a graph of the bearing capacity function. In this case, the steel consumption will be less.

It was found that with a decrease in the linear load on the beam and the flexibility of the wall, as well as with an increase in span, this coefficient becomes smaller. Therefore, it is recommended to reduce the height of the beam in areas near the supports at relatively small loads and wall flexibility and relatively large spans.

Key words: optimization, bending, beam height, wall flexibility, lower belt slope, shear strength. 


\section{MICT}

Гілодо О.Ю., Арсірій А.М.

Напружено-деформований стан в' язового вузла каркасного багатоповерхового дерев'яного будинку

Безушко Д.І., Арсірій О.І., Іллічов В.Г.

Визначення геометричних характеристик шпунту для розрахунків деформування тонких стінок у 2D постановці

Бояджі А.О., Бойко А.В., Стоянов В.О.

Застосування дерев'яних двотаврових балок з вузлами з трубчастих сталевих

елементів у конструкціях кружально-сітчастих склепіннь

Гібаленко О.М., Гібаленко В. А., Бочарова О.А.

Технологічність робіт забезпечення вторинного захисту металоконструкцій від корозії в умовах хімічно активних середовищ

Голоднов О.І., Антошина Т.В.

Досвід проектування та будівництва навісу над будівлею

Гудзь С.А., Гасій Г.М., Дарієнко В.В.

Розвинена модель розрахунку сталевих розкріплених елементів на стійкість при сумісній дії поперечного згину та кручення

Карпюк В. М., Даниленко Д.С., Карпюк І.А., Даниленко А.В., Сьоміна Ю.А. Фізична модель роботи системи «металева попередньо напружена обойма підсилення - пошкоджена залізобетонна балка»

Коломійчук Г.П., Коломійчук В.Г.

Просторова трансформація конструктивних елементів сучасних оболонок покрить

Маладика І.Г., Шкарабура І.М., Антошина Т.В., Іванов Б.В.

Забезпечення вогнестійкості експлуатованих сталевих конструкцій

Махінько А.В., Махінько Н.О.

Практичні підходи до розрахунку надійності багатоболтових з'єднань листів корпусу силосних ємностей

\section{Найчук А.Я.}

Оцінка несучої здатності опорних вузлів дерев'яних клеєних балок з підрізками

Попаденко А.О., Колесніченко С.В.

Щодо можливості використання термографічного способу контролю для виявлення тріщин у сталевих конструкціях

Романенко С.М., Андрієвська Я.П.

Розрахунок дерев'яної рами будівлі з урахуванням влаштування на покрівлі елементів альтернативної енергії 


\section{Сінгаӥвський П.М., Купченко Ю.В.}

Оцінка напружено-деформованого стану ферм покриттів одноповерхових промислових будівель в торцевих в'язевих блоках з врахуванням вітрового тиску в торець будівлі

\section{Шехоркіна С.Е.}

Експериментальне дослідження болтового з'єднання елементів 3 клеєної деревини на металевих пластинах

Шурин А.Б., Мухін А.В.

Досвід конструювання ферм із гнутозварних профілей у відповідності до вимог EN 1993-1

Янін О.С., Новікова С.М.

Оптимізація висоти сталевої зварної двотаврової балки на ділянках біля опор 


\section{CONTENTS}

Gilodo A.Y., Arsiriy A.N.

Strain-stress distribution of braced node of framed multi-storey wooden house

Bezushko D., Arsirii E., Illichov V.

Determination of geometric characteristics of wings for calculations of thin wall

deformation in $2 \mathrm{D}$ production

Boiadzhi A.O., Boyko A.V., Stoyanov V.V.

Designs of lamella roof with wooden I-beamsand nodes of tubular elements

Gibalenko O. M., Gibalenko V.A., Bocharova O.A.

Technological work of providing secondary protection of metal structures against corrosion in conditions of chemical active environments

Holodnov O., Antoshina T.

Experience of designing and construction of baldachins over the building

Hudz, S.A., Gasii G.M., Darienko V.V.

Developed model of steel restrained elements design for stability by the compatible action of transverse bending and torsion

Karpiuk V.M., Danilenko D.S., Karpiuk I.A., Danilenko A.V., Somina Yu.A.

Physical model of work of the system «metal preliminary tension reinforcement jacket damaged reinforced concrete beam»

Kolomiychuk G.P., Kolomiichuk V.G.

Spatial transformation of structural elements of modern coatings shells

Maladyka I., Shkarabura I.M., Antoshina T., Ivanov B.

Providing of fire-resistance of the exploited steel constructions

Makhinko A.V., Makhinko N.O.

Practical approaches to calculating the reliability of multiple-bolt joints of the silo body sheets

Naichuk A.Ya.

The load bearing capacity of glulam beams with notches at the support

Popadenko A.O., Kolesnichenko S.V.

The possibility of thermographic control method application for detection of cracks in steel structures

Romanenko S.M., Andriievska Y.P.

Calculation of a wooden frame of a building taking into account the device on the roof of alternative energy elements 


\section{Singayevsky P. M., Kupchenko Y.V.}

Evaluation of the stressed-strain condition of the roof trusses of one-storeyed industrial building in the end brace blocks taking into account the wind pressure at the flank of the building

\section{Shekhorkina S.Yev.}

Experimental investigation of bolted timber connections with steel plates

\section{Shuryn A.B., Muhin A.V.}

Experience of designing steel trusses from rectangular hollow sections according to EN 1993-1 requirements

\section{Yanin A.E., Novikova S.N.}

Height optimization of a steel welded i-beam in areas at the supports 